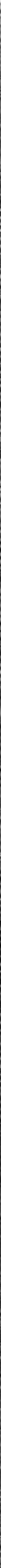


Stolberg, 6I.

Sturz, I60-162.

Swift, 69, I46, I57, I60.

v. Thümmel, 93, I35, I 55 .

Timme, I68-I79.

Usteri, 30.

Wagner, H. L., 4I, I57.

Wegener, I5O-I5I.

Weisse, Chr. Felix, 68.

Wezel, I 10, I38, I44-I 50, I79-I8I.
Wieland, I0, I4, 31, 32, 42, 59, 6I, 73, 90, 93-99, I03, I46, I56, I8г.

Wilkes, 64.

Wittenberg, 53, 87.

v. Wolzogen, 153 .

Young, 7, I0, I49-150.

Zelter, 98, 102.

Ziegler, Louise v. (Lila), 89.

Zimmermann, 3I, 59.

Zückert, 12-I8, 22, 31, 32, 37, 58$60,99$. 
COLUMBIA UNIVERSITY GERMANIC STUDIES

Vol. II. No. II.

\title{
TYPES OF WELTSCHMERZ IN GERMAN POETRY
}

B Y

\author{
WILHELM ALFRED BRAUN, Ph.D. \\ SOMETIME FELLOW IN GERMANIC LANGUAGES AND \\ LITERATURE8, COLUMBIA UNIVERSITY
}

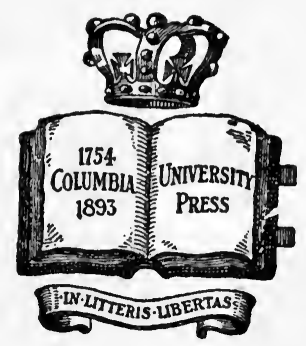

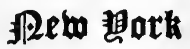

THE COLUMBIA UNIVERSITY PRESS

The Macmillan Company, Agents

London: Macmillan \& Co., Ltd.

1905

All rights reserved 


\section{COLUMBIA UNIVERSITY GERMANIC STUDIES}

Edited by William H. Carpenter and Calvin Thomas

$$
\text { Vol. I }
$$

No. I. SCANDINAVIAN INFLUENCE ON SOUTHERN LOWLAND SCOTCH. A Contribution to the Study of the Linguistic Relations of English and Scandinavian. By Grorge Tobias Flom, Ph.D. 8vo, paper, pp. $x v+82$. Price, $\$ 1.00$ net.

No. 2. OSSIAN IN GERMANY. Bibliography, General Survey, Ossian's Influence on Klopstock and the Bards. By Rudolf Tомвo, JR., Ph.D. 8vo, paper, pp. iv + 157. Price, $\$ \mathbf{I} .00$ net.

No. 3. THE INFLUENCE OF OLD NORSE LITERATURE UPON ENGLISH LITERATURE. By Conrad Hjalmar Nordby. 8vo, paper, pp. xi 78 . Price, \$I.OO net.

No. 4. THE INFLUENCE OF INDIA AND PERSIA ON THE POETRY OF GERMANY. By ARTHUR F. J. Remy, Ph.D. 8vo, paper, pp. xi+8i. Price, \$I.0O net.

$$
\text { Vol. II }
$$

No. I. LAURENCE STERNE IN GERMANY. A Contribution to the Study of the Literary Relations of England and Germany in the Eighteenth Century. By Harvey Waterman Thayer, Ph.D. 8vo, paper. Price, \$I.00 net.

No. 2. TYPES OF WELTSCHMERZ IN GERMAN POETRY. By Wilhelm Alfred Braun, Ph.D. 8vo, paper. Price, $\$ \mathbf{I} .00$ net. 
COLUMBIA UNIVERSITY GERMANIC STUDIES

Vol. II. No. II.

\title{
TYPES OF WELTSCHMERZ IN GERMAN POETRY
}

B Y

\author{
WILHELM ALFRED BRAUN, Ph.D. \\ SOMETIME FELLOW IN GERMANIC LANGUAGES AND \\ LITERATURE8, COLUMBIA UNIVERSITY
}

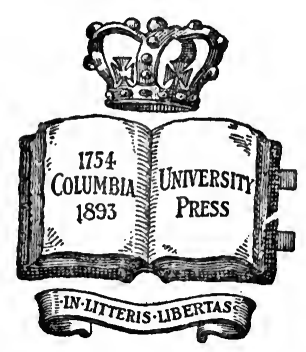

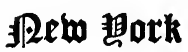

THE COLUMBIA UNIVERSITY PRESS

The Macmillan Company, Agents

London: Macmillan \& Co., Ltd.

1905

All rights reserved 
Copyright, 1905

By THE MACMILLAN COMPANY

Printed from type September, 1905 


\section{NOTE}

The author of this essay has attempted to make, as he himself phrases it, "a modest contribution to the natural history of Weltschmerz." What goes by that name is no doubt somewhat elusive; one can not easily delimit and characterize it with scientific accuracy. Nevertheless the word corresponds to a fairly definite range of psychical reactions which are of great interest in modern poetry, especially German poetry. The phenomenon is worth studying in detail. In undertaking a study of it $\mathrm{Mr}$. Braun thought, and I readily concurred in the opinion, that he would do best not to essay an exhaustive history, but to select certain conspicuously interesting types and proceed by the method of close analysis, characterization and comparison. I consider his work a valuable contribution to literary scholarship.

Calvin Thomas.

Columbia University, June, 1905 
Digitized by the Internet Archive in 2007 with funding from Microsoft Corporation 


\section{PREFACE}

ThE work which is presented in the following pages is intended to be a modest contribution to the natural history of Weltschmerz.

The writer has endeavored first of all to define carefully the distinction between pessimism and Weltschmerz; then to classify the latter, both as to its origin and its forms of expression, and to indicate briefly its relation to mental pathology and to contemporary social and political conditions. The three poets selected for discussion, were chosen because they represent distinct types, under which probably all other poets of Weltschmerz may be classified, or to which they will at least be found analogous; and to the extent to which such is the case, the treatise may be regarded as exhaustive. In the case of each author treated, the development of the peculiar phase of Weltschmerz characteristic of him has been traced, and analyzed with reference to its various modes of expression. Hölderlin is the idealist, Lenau exhibits the profoundly pathetic side of Weltschmerz, while Heine is its satirist. They have been considered in this order, because they represent three progressive stages of Weltschmerz viewed as a psychological process: Hölderlin naive, Lenau self-conscious, Heine endeavoring to conceal his melancholy beneath the disguise of self-irony.

It is a pleasure to tender my grateful acknowledgments to my former Professors, Calvin Thomas and William H. Carpenter of Columbia University, and Camillo von Klenze and Starr Willard Cutting of the University of Chicago, under whose stimulating direction and never-failing assistance my graduate studies were carried on.

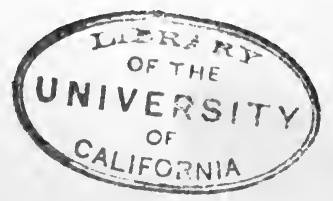





\section{CONTENTS}

Chapter I-Introduction . . . . . . . . . . . I

Chapter II-Hölderlin . . . . . . . . . . . .

Chapter III-Lenau . . . . . . . . . . . . 35

Chapter IV-Heine . . . . . . . . . . . . . 59

Chapter V-Bibliography . . . . . . . . . . 85 



\section{CHAPTER I}

\section{Introduction}

The purpose of the following study is to examine closely certain German authors of modern times, whose lives and writings exemplify in an unusually striking degree that peculiar phase of lyric feeling which has characterized German literature, often in a more or less epidemic form, since the days of "Werther," and to which, at an early period in the nineteenth century, was assigned the significant name "Weltschmerz."

With this side of the poet under investigation, there must of necessity be an enquiry, not only into his writings, his expressed feelings, but also his physical and mental constitution on the one hand, and into his theory of existence in general on the other. Psychology and philosophy then are the two adjacent fields into which it may become necessary to pursue the subject in hand, and for this reason it is only fair to call attention to the difficulties which surround the student of literature in discussing philosophical ideas or psychological phenomena. Intrepid indeed would it be for him to attempt a final judgment in these bearings of his subject, where wise men have differed and doctors have disagreed.

Although sometimes loosely used as synonyms, it is necessary to note that there is a well-defined distinction between Weltschmerz and pessimism. Weltschmerz may be defined as the poetic expression of an abnormal sensitiveness of the feelings to the moral and physical evils and misery of existence-a condition which may or may not be based upon a reasoned conviction that the sum of human misery is greater than the sum of human happiness. It is usually characterized also by a certain lack of will-energy, a sort of sentimental yielding to these painful emotions. It is therefore entirely a matter of "Gemüt." Pessi- 
mism, on the other hand, purports to be a theory of existence, the result of deliberate philosophic argument and investigation, by which its votaries have reached the dispassionate conclusion that there is no real good or pleasure in the world that is not clearly outweighed by evil or pain, and that therefore selfdestruction, or at least final annihilation is the consummation devoutly to be wished.

James Sully, in his elaborate treatise on Pessimism, ${ }^{1}$ divides it, however, into reasoned and unreasoned Pessimism, including Weltschmerz under the latter head. This is entirely compatible with the definition of Weltschmerz which has been attempted above. But it is interesting to note the attitude of the pessimistic school of philosophy toward this unreasoned pessimism. It emphatically disclaims any interest in or connection with it, and describes all those who are afflicted with the malady as execrable fellows-to quote Hartmann-: "Klageweiber männlichen und weiblichen Geschlechts, welche am meisten zur Discreditierung des Pessimismus beigetragen haben, die sich in ewigem Lamento ergehen, und entweder unaufhörlich in Thränen schwimmen, oder bitter wie Wermut und Essig, sich selbst und andern das Dasein noch mehr vergällen; eine jämmerliche Situation des Stimmungspessimismus, der sie nicht leben und nicht sterben lässt." 2 And yet Hartmann himself does not hesitate to admit that this very condition of individual Weltschmerz, or "Zerrissenheit," is a necessary and inevitable stage in the progress of the mind toward that clarified universal Weltschmerz which is based upon theoretical insight, namely pessimism in its most logical sense. This being granted, we shall not be far astray in assuming that it is also the stage to which the philosophic pessimist will sometimes revert, when a strong sense of his own individuality asserts itself.

If we attempt a classification of Weltschmerz with regard to its essence, or, better perhaps, with regard to its origin, we shall find that the various types may be classed under one of two

1 "Pessimism, a History and a Criticism," London, 1877.

${ }^{2}$ Ed. von Hartmann: "Zur Geschichte und Begründung des Pessimismus," Leipzig, Hermann Haacke, p. I87. 
heads: either as cosmic or as egoistic. The representatives of cosmic Weltschmerz are those poets whose first concern is not their personal fate, their own unhappiness, it may be, but who see first and foremost the sad fate of humanity and regard their own misfortunes merely as a part of the common destiny. The representatives of the second type are those introspective natures who are first and chiefly aware of their own misery and finally come to regard it as representative of universal evil. The former proceed from the general to the particular, the latter from the particular to the general. But that these types must necessarily be entirely distinct in all cases, as Marchand ${ }^{1}$ asserts, seems open to serious doubt. It is inconceivable that a poet into whose personal experience no shadows have fallen should take the woes of humanity very deeply to heart ; nor again could we imagine that one who has brooded over the unhappy condition of mankind in general should never give expression to a note of personal sorrow. It is in the complexity of motives in one and the same subject that the difficulty lies in making rigid and sharp distinctions. In some cases Weltschmerz may arise from honest conviction or genuine despair, in others it may be something entirely artificial, merely a cloak to cover personal defects. Sometimes it may even be due to a desire to pose as a martyr, and sometimes nothing more than an attempt to ape the prevailing fashion. To these types Wilhelm Scherer adds "Müssiggänger, welche sich die Zeit mit übler Laune vertreiben, missvergnügte Lyriker, deren Gedichte nicht mehr gelesen werden, und Spatzenköpfe, welche den Pessimismus für besonderen Tiefsinn halten und um jeden Preis tiefsinnig erscheinen wollen.",2

But it is with Weltschmerz in its outward manifestations as it finds expression in the poet's writings, that we shall be chiefly concerned in the following pages. And here the subdivisions, if we attempt to classify, must be almost as numerous as the representatives themselves. In Hölderlin we have the ardent Hellenic idealist; Lenau gives expression to all the pathos of

1 "Les Poètes Lyriques de l'Autriche," Paris, I886, p. 293.

2 "Vorträge und Aufsätze zur Geschichte des geistigen Lebens in Deutschland und Oesterreich," Berlin, 1874, p. 413. 
Weltschmerz, Heine is its satirist, the misanthrope, while in Raabe we even have a pessimistic humorist.

This brief list needs scarcely be supplemented by other names of poets of melancholy, such as Reinhold Lenz, Heinrich von Kleist, Robert Southey, Byron, Leopardi, in order to command our attention by reason of the tragic fate which ended the lives of nearly all of these men, the most frequent and the most terrible being that of insanity. It is of course a matter of common knowledge that chronic melancholy or the persistent brooding over personal misfortune is an almost inevitable preliminary to mental derangement. And when this melancholy takes root in the finely organized mind of genius, it is only to be expected that the result will be even more disastrous than in the case of the ordinary mind. Lombroso holds the opinion that if men of genius are not all more or less insane, that is, if the "spheres of influence" of genius and insanity do not actually overlap, they are at least contiguous at many points, so that the transition from the former to the latter is extremely easy and even natural. But genius in itself is not an abnormal mental condition. It does not even consist of an extraordinary memory, vivid imagination, quickness of judgment, or of a combination of all of these. Kant defines genius as the talent of invention. Originality and productiveness are the fundamental elements of genius. And it is an almost instinctive force which urges the author on in his creative work. In the main his activity is due less to free will than to this inner compulsion.

\footnotetext{
"Ich halte diesen Drang vergebens auf,

Der Tag und Nacht in meinem Busen wechselt.

Wenn ich nicht sinnen oder dichten soll,

So ist das Leben mir kein Leben mehr,"
}

says Goethe's Tasso. ${ }^{1}$ If this impulse of genius is embodied in a strong physical organism, as for example in the case of Shakespeare and Goethe, there need be no detriment to physical health; otherwise, and especially if there is an inherited tendency to disease, there is almost sure to be a physical collapse. Specialists in the subject have pointed out that violent passions are even more potent in producing mental disease than mere

${ }^{1}$ Act 5, Sc. 2. 
intellectual over-exertion. And these are certainly characteristic in a very high degree of the mind of genius. It has often been remarked that it is the corona spinosa of genius to feel all pain more intensely than do other men. Schopenhauer says "der, in welchem der Genius lebt, leidet am meisten." It is only going a step further then, when Hamerling writes to his friend Möser: "Schliesslich ist es doch nur der Kranke, der sich das Leid der ganzen Welt zu Herzen nimmt."

Radestock, in his study "Genie und Wahnsinn," mentions and elaborates among others the following points of resemblance between the mind of genius and the insane mind: an abnormal activity of the imagination, very rapid succession of ideas, extreme concentration of thought upon a single subject or idea, and lastly, what would seem the cardinal point, a weakness of will-energy, the lack of that force which alone can serve to bring under control all these other unruly elements and give balance to what must otherwise be an extremely one-sided mechanism. Here again the exception may be taken to prove the rule. It is not too much, I think, to assert that Goethe could never have become so uniquely great, not even through the splendid versatility of his genius, but for that incomparable self-control, which he made the watchword of his life. And in the case of the poet of Weltschmerz the presence or absence of this quality may even decide whether he shall rise superior to his beclouded condition or perish in the gloom. The conclusion at which Radestock arrives is that genius, as the expression of the most intense mental activity, occupies the middle ground, as it were, between the normal healthy state on the one hand, and the abnormal, pathological state on the other, and has without doubt many points of contact with mental disease; and that although the elements which genius has in common with insanity may not be strong enough in themselves to induce the transition from the former to the latter state, yet when other aggravating causes are added, such as physical disease, violent emotions or passions, overwork, the pressure or distress of outward circumstances, the highly gifted individual is much more liable to cross the line of demarkation between the two mental states than is the average mind, which is more 
remote from that line. If this can be asserted of genius in general, it must be even more particularly and widely applicable in reference to a combination of genius and Weltschmerz. We shall find pathetic examples in the first two types selected for examination.

Having thus introduced the subject in its most general bearings and aspects, it remains for us to review briefly its historical background.

Weltschmerz is essentially a symptom of a period of conflict, of transition. The powerful reaction which marks the eighteenth century - a reaction against all traditional intellectual authority, and a struggle for the emancipation of the individual, of research, of inspiration and of genius-reached its high-water mark in Germany in the seventies. But with the unrestrained outbursts of the champions of Storm and Stress the problem was by no means solved; there remained the basic conflict between the idea of personal liberty and the strait-jacket of Frederician absolutism, the conflict between the dynastic and the national idea of the state. Should the individual yield a blind, unreasoned submission to the state as to a divinely instituted arbitrary authority, good or bad, or was the state to be regarded as the conscious and voluntary coöperation of its subjects for the general good? It was, moreover, a time not only of open and active revolt, as represented by the spirit of Klinger, but also of great emotional stirrings, and sentimental yearnings of such passive natures as Hölty. Rousseau's plea for a simplified and more natural life had exerted a mighty influence. And what has a most important bearing upon the relation between these intellectual currents and Weltschmerz-these minds were lacking in the discipline implied in our modern scientific training. Scientific exactness of thinking had not become an integral part of education. Hence the difference between the pessimism of Ibsen and the romantic Weltschmerz of these uncritical minds.

In accounting for the tremendous effect produced by his "Werther," Goethe compares his work to the bit of fuse which explodes the mine, and says that the shock of the explosion was so great because the young generation of the day had already 
undermined itself, and its members now burst forth individually with their exaggerated demands, unsatisfied passions and imaginary sufferings. ${ }^{1}$ And in estimating the influences which had prepared the way for this mental disposition, Goethe emphasizes the influence of English literature. Young's "Night Thoughts," Gray's "Elegy," Goldsmith's "Deserted Village," even "Hamlet" and his monologues haunted all minds. "Everyone knew the principal passages by heart, and everyone believed he had a right to be just as melancholy as the Prince of Denmark, even though he had seen no ghost and had no royal father to avenge." Finally Ossian had provided an eminently suitable setting,- - under the darkly lowering sky the "endless gray heath, peopled with the shadowy forms of departed heroes and withered maidens. To quote the substance of Goethe's criticism:2 Amid such influences and surroundings, occupied with fads and studies of this sort, lacking all incentive from without to any important activity and confronted by the sole prospect of having to drag out a humdrum existence, men began to reflect with a sort of sullen exultation upon the possibility of departing this life at will, and to find in this thought a scant amelioration of the ills and tedium of the times. This disposition was so general that "Werther" itself exerted a powerful influence, because it everywhere struck a responsive chord and publicly and tangibly exhibited the true inwardness of a morbid youthful illusion. ${ }^{3}$

Nor did the dawning nineteenth century bring relief. No other period of Prussian history, says Heinrich von Treitschke, ${ }^{4}$ is wrapped in so deep a gloom as the first decade of the reign of Frederick William III. It was a time rich in hidden intellectual forces, and yet it bore the stamp of that uninspired philistinism which is so abundantly evidenced by the barren

1 "Gcethes Werke," Weimar ed. Vol. 28, p. 227 f.

2 Ibid., p. $216 \mathrm{f}$.

In view of Goethe's own words, then, the caution of a recent critic (Felix Melchior in Litt. Forsch. XXVII Heft, Berlin, r903) against applying the term Weltschmerz to "Werther," would seem to miss the mark entirely. Werther is a type, just as truly as is Faust, though in a smaller way, and the malady which he typifies has its ultimate origin in the development of public life,-the very condition which this critic insists upon as a mark of Weltschmerz in the proper application of the term.

4"Historische und politische Aufsätze," Leipzig, 1897. Vol. 4. 
commonplace character of its architecture and art. Genius there was, indeed, but never were its opportunities for public usefulness more limited. It was as though the greatness of the days of the second Frederick lay like a paralyzing weight upon this generation. And this oppressing sense of impotence was followed, after the Napoleonic Wars, by the bitterness of disappointment, all the more keenly felt by reason of this first reawakening of the national consciousness. Great had been the expectations, enormous the sacrifice; exceedingly small was the gain to the individual. ${ }^{1}$ And the resultant dissonance was the same as that to which Alfred de Musset gave expression in the words: "The malady of the present century is due to two causes; the people who have passed through I793 and I8I4 bear in their hearts two wounds. All that was is no more; all that will be is not yet. Do not hope to find elsewhere the secret of our ills." 2

This then in briefest outline is the transition from the century of individualism and autocracy to the nineteenth century of democracy. Small wonder that the struggle claimed its victims in those individuals who, unable to find a firm basis of conviction and principle, vacillated constantly between instinctive adherence to old traditions, and unreasoned inclination to the new order of things.

\footnotetext{
1 As early as 1797 Hölderlin's Hyperion laments: "Mein Geschäft auf Erden ist aus. Ich bin voll Willens an die Arbeit gegangen, habe geblutet darüber, und die Welt um keinen Pfennig reicher gemacht." ("Hölderlin's gesammelte Dichtungen, herausgegeben von B. Litzmann," Stuttgart, Cotta, undated. Vol. II, p. 68.) Several decades later Heine writes: "Ich kann mich über die Siege meiner liebsten Ueberzeugungen nicht recht freuen, da sie mir gar zu viel gekostet haben. Dasselbe mag bei manchem ehrlichen Manne der Fall sein, und es trägt viel bei zu der grossen düsteren Verstimmung der Gegenwart." (Brief vom 21 April, r85r, an Gustav Kolb; Werke, Karpeles ed. Vol. IX, p. 378.)

2 "Confession d'un enfant du siècle." CEuvres compl. Paris, r888 (Charpentier). Vol. VIII, p. 24.
} 


\section{CHAPTER II}

\section{Hölderlin}

A case such as that of Hölderlin, subject as he was from the time of his boyhood to melancholy, and ending in hopeless insanity, at once suggests the question of heredity. Little or nothing is known concerning his remote ancestors. His greatgrandfather had been administrator of a convent at Grossbottwar, and died of dropsy of the chest at the age of forty-seven. His grandfather had held a similar position as "Klosterhofmeister und geistlicher Verwalter" at Lauffen, to which his son, the poet's father, succeeded. An apoplectic stroke ended his life at the early age of thirty-six. In regard to Hölderlin's maternal ancestors, our information is even more scant, though we know that both his grandmother and his mother lived to a ripe old age. From the poet's references to them we judge them to have been entirely normal types of intelligent, lovable women, gifted with a great deal of good practical sense. The only striking thing is the premature death of Hölderlin's greatgrandfather and father. But in view of the nature of their stations in life, in which they may fairly be supposed to have led more than ordinarily sober and well-ordered lives, there seems to be no ground whatever for assuming that Hölderlin's Weltschmerz owed its inception in any degree to hereditary tendencies, notwithstanding Hermann Fischer's opinion to the contrary. ${ }^{1}$ There is no sufficient reason to assume "erbliche Belastung," and there are other sufficient causes without merely guessing at such a possibility.

But while there are no sufficient historical grounds for the supposition that he brought the germ of his subsequent mental disease with him in his birth, we cannot fail to observe, even in

Inz. f. d. Alt., vol. 22, p. $212-218$. 
the child, certain natural traits, which, being allowed to develop unchecked, must of necessity hasten and intensify the gloom which hung over his life. To his deep thoughtfulness was added an abnormal sensitiveness to all external influences. Like the delicate anemone, he recoiled and withdrew within himself when touched by the rougher material things of life. ${ }^{1}$ He himself poetically describes his absentmindedness when a boy, and calls himself "ein Träumer"; and a dreamer he remained all his life. It seems to have been this which first brought him into discord with the world:

Oft sollt' ich stracks in meine Schule wandern,

Doch ehe sich der Träumer es versah,

So hatt' er in den Garten sich verirrt,

Und sass behaglich unter den Oliven,

Und baute Flotten, schifft' ins hohe Meer.

Dies kostete mich tausend kleine Leiden,

Verzeihlich war es immer, wenn mich oft

Die Klügeren, mit herzlichem Gelächter

Aus meiner seligen Ekstase schreckten,

Doch unaussprechlich wehe that es mir. ${ }^{2}$

If ever a boy needed a strong fatherly hand to guide him, to teach him self-reliance and practical sense, it was this dreamy, tender-spirited child. ${ }^{3}$ The love and sympathy which his mother bestowed upon him was not calculated to fit him for the rugged experiences of life, and while probably natural and pardonable, it was nevertheless extremely unfortunate that the boy was unconsciously encouraged to be and to remain a "Muttersöhnchen." But even with his peculiar trend of disposition, the result might not have been an unhappy one, had the course of his life not brought him more than an ordinary share of misfortune. This overtook him early in life, for when but two

\footnotetext{
${ }^{1}$ In a letter to his mother he writes: "Freilich ist's mir auch angeboren, dass ich alles schwerer zu Herzen nehme." ("Friedrich Hölderlins Leben, in Briefen von und an Hölderlin, von Carl C. T. Litzmann," Berlin, 1890, p. 27. Hereafter quoted as "Briefe.").

2 "Hölderlins gesammelte Dichtungen, herausgegeben von B. Litzmann," Stuttgart, Cotta (hereafter quoted as "Werke"). Vol. II, p. 9.

${ }^{3}$ It is a reminiscence of Hölderlin's boyhood which finds expression in the words of Hyperion: "Ich war aufgewachsen, wie eine Rebe ohne Stab, und die wilden Ranken breiteten richtungslos über dem Boden sich aus." Werke, Vol. II, p. 72.
} 
years of age his father died. His widowed mother now lived for a few years in complete retirement with her two childrenthe poet's sister Henrietta having been born just a few weeks after his father's demise. But it was not long before death again entered the household and robbed it of Hölderlin's aunt, his deceased father's sister, who was herself a widow and the faithful companion of the poet's mother. When the latter found herself again alone with her two little ones, whose care was weighing heavily upon her, she consented to become the wife of her late husband's friend, Kammerrat Gock, and accompanied him to his home in the little town of Nürtingen on the Neckar. But this re-established marital happiness was to be of brief duration, for in 1779 her second husband died, and the mother was now left with four little children to care and provide for.

The frequency with which death visited the family during his childhood and youth, familiarized him at an early age with scenes of sorrow and grief. No doubt he was too young when his father died to comprehend the calamity that had come upon the household, but it was not many months before he knew the meaning of his mother's tears, not only for his father, but also for his sister, who died in her infancy. Referring to his father's death, he writes in one of his early poems, "Einst und Jetzt" : 1

Einst schlugst du mir so ruhig, empörtes Herz!

Einst in des Vaters Schoosse, des liebenden

Geliebten Vaters, - aber der Würger kam,

Wir weinten, flehten, doch der Würger

Schnellte den Pfeil, und es sank die Stütze.

At his tenderest and most impressionable age, the boy was thus made sadly aware of the fleetingness of human life and the pains of bereavement. We cannot wonder then at finding these impressions reflected in his most juvenile poetic attempts. His poem "Das menschliche Leben," written at the age of fifteen, begins :

Menschen, Menschen! was ist euer Leben,

1 Werke, Vol. I, p. 86. 
Eure Welt, die thränenvolle Welt!

Dieser Schauplatz, kann er Freude geben

Wo sich Trauern nicht dazu gesellt? ? $^{1}$

But a time of still greater unhappiness was in store for him when he left his home at the age of fourteen to enter the convent school at Denkendorf, where he began his preparation for a theological course. A more direct antithesis to all that his body and soul yearned for and needed for their proper development could scarcely have been devised than that which existed in the chilling atmosphere and rigorous discipline of the monastery. He had not even an incentive to endure hardships for the sake of what lay beyond, for it was merely in passive submission to his mother's wish that he had decided to enter holy orders. And now, clad in a sombre monkish gown, deprived of all freedom of thought or movement and forced into companionship with twenty-five or thirty fellows of his own age, who nearly all misunderstood him, Hölderlin felt himself wretched indeed. "Wär' ich doch ewig ferne von diesen Mauern des Elends!" he writes in a poem at Maulbronn in $1787 .^{2}$ There was for him but one way of escape. It was to isolate himself as much as possible from the world of harsh reality about him, to be alone, and there in his solitude to construct for himself an ideal world of fancy, a poetic dreamland. This mental habit not only remained with him as he grew into manhood, it may be said to have been through life one of his most distinguishing characteristics. It would be impossible to make room here for all the passages in his poems and letters of this period, which reflect his love of solitude and his habit of retreating into a world of his own imagining. His letters to his friend Nast almost invariably contain some expression of his heart-ache. "Bilfinger ist wohl mein Freund, aber es geht ihm zu glücklich, als dass er sich nach mir umsehen möchte. Du wirst mich schon verstehen-er ist immer lustig, ich hänge immer den Kopf." 3 Another letter begins : "Wieder eine Stunde wegphantasiert!-dass es doch so schlechte Menschen giebt, unter meinen Cameraden so elende Kerls-

${ }^{1}$ Werke, Vol. I, p. 36.

2 "Auf einer Heide geschrieben," Werke, Vol. I, p. 44.

${ }^{3}$ Briefe, p. 27. 
wann mich die Freundschaft nicht zuweilen wieder gut machte, so hätt' ich mich manchmal schon lieber an jeden andern Ort gewünscht, als unter Menschengesellschaft.-Wann ich nur auch einmal etwas recht Lustiges schreiben könnte! Nur Gedult! 's wird kommen-hoff' ich, oder-oder hab' ich dann nicht genug getragen? Erfuhr ich nicht schon als Bube, was den Mann seufzen machen würde? und als Jüngling, geht's da besser?-Du lieber Gott! bin ich's denn allein? jeder andre glücklicher als ich? Und was hab' ich dann gethan?"1 There is a world of pathos in this helpless cry of pain, with its suggestion of retributive fate. A poem of 1788 , "Die Stille," written at Maulbronn, epitomizes almost everything that we have thus far noted as to Hölderlin's nature. He goes back in fancy to the days of his childhood, describing his lonely rambles, from which he would return in the moonlight, unmindful of his lateness for the evening meal, at which he would hastily eat of that which the others had left:

Schlich mich, wenn ich satt gegessen,

Weg von meinem lustigen Geschwisterpaar.

O! in meines kleinen Stübchens Stille

War mir dann so über alles wohl,

Wie im Tempel war mir's in der Nächte Hülle,

Wann so einsam von dem Turm die Glocke scholl.

Als ich weggerissen von den Meinen

Aus dem lieben elterlichen Haus

Unter Fremden irrte, wo ich nimmer weinen

Durfte, in das bunte Weltgewirr hinaus,

$O$ wie pflegtest du den armen Jungen,

Teure, so mit Mutterzärtlichkeit,

Wann er sich im Weltgewirre müd gerungen,

In der lieben, wehmutsvollen Einsamkeit. ${ }^{2}$

This love of solitude is carried to the extreme in his contemplation of a hermit's life. In a letter to Nast he says: "Heute ging ich so vor mich hin, da fiel mir ein, ich wolle nach vollendeten Universitäts Jahren Einsiedler werden-und der Gedanke

1 Briefe, p. 29.

2 Werke, Vol. I, p. 53 f. 
gefiel mir so wohl, eine ganze Stunde, glaub' ich, war ich in meiner Fantasie Einsiedler."' And although he never became a hermit, this is the final disposition which he makes of himself in his "Hyperion."

These habits of thought and feeling, formed in boyhood, could lead to only one result. He became less and less qualified to comprehend and to grapple with the practical problems and difficulties of life, and entered young manhood and the struggle for existence at a tremendous disadvantage.

Another trait of his character which served to intensify his subsequent disappointments, was the strong ambition which early filled his soul. $\mathrm{He}$ aspired to high achievements in his chosen field of art. In a letter to Louise Nast, written probably about the beginning of I790, he makes the confession: "Der unüberwindliche Trübsinn in mir ist wohl nicht ganz, doch meist-unbefriedigter Ehrgeiz."' The mere lad of seventeen had scarcely learned to admire Klopstock, when he speaks of his own "kämpfendes Streben nach Klopstocksgrösse," and exclaims: "Hinan den herrlichen Ehrenpfad! Hinan! im glühenden kühnen Traum, sie zu erreichen!"3 It is remarkable to note how this fancy of a dream-life becomes fixed in Hölderlin's mind and reappears in almost every poem. Closely allied to this idea is that of a "glückliche Trunkenheit," and expressions like "wie ein Göttertraum das Alter schwand," "liebetrunken," "Wie ein Traum entfliehen Ewigkeiten," "siegestrunken," "süsse, kühne Trunkenheit," "trunken dämmert die Seele mir," can be found on almost every page of his shorter poems. Hyperion expresses himself on one occasion in the words: "O ein Gott ist der Mensch, wenn er träumt, ein Bettler, wenn er nachdenkt, und wenn die Begeisterung hin ist, steht er da, wie ein missrathener Sohn, den der Vater aus dem Hause stiess, und betrachtet die ärmlichen Pfennige, die ihm das Mitleid auf den Weg gab," 4 which further illustrates the extravagant idealism by which he allowed himself to be carried away, and the etherial and thoroughly unpractical trend of his

1 Briefe, p. 36 .

2 Briefe, p. 120.

3 "Mein Vorsatz," Werke, Vol. I, p. 44.

${ }^{4}$ Werke, Vol. II, p. 69. 
mind. The flights of fancy of which Hölderlin is capable are well illustrated by another passage in "Hyperion." Referring to Hyperion's conversation with Alabanda, he says: "Ich war hingerissen von unendlichen Hoffnungen, Götterkräfte trugen wie ein Wölkchen mich fort." ${ }_{1}$ These facts have a direct bearing upon Hölderlin's Weltschmerz, inasmuch as it was just this unequal and unsuccessful struggle of the idealist with the stern realities of life that brought about the catastrophe which wrought his ruin.

And just as his ideals are vague and abstract, so too are the expressions of his Weltschmerz. It needs no concrete idea to arouse his enthusiasm to its highest pitch. Thus Hyperion exclaims: "Der Gott in uns, dem die Unendlichkeit zur Bahn sich öffnet, soll stehen und harren, bis der Wurm ihm aus dem Wege geht? Nein! nein! man frägt nicht, ob ihr wollt! ihr wollt ja nie-ihr Knechte und Barbaren! Euch will man auch nicht bessern, denn es ist umsonst! Man will nur dafür sorgen, dass ihr dem Siegeslauf der Menschheit aus dem Wege geht!"' It is in the form of lofty generalities such as these, and seldom with reference to practical details, that Hölderlin's longings find expression.

Entirely consistent with this idealism is the nature of his love, ardent, but etherial, "übersinnlich." This is reflected also in his lyrics, which are statuesque and beautiful, but lacking in passion and sensuous charm. Hölderlin's earliest loveaffair, that with Louise Nast, is important for his Weltschmerz only in its bearing upon the development of his general character. This influence was a twofold one: in the first place his sweetheart was herself inclined to a sort of visionary mysticism, and therefore had an unwholesome influence upon the youth, who had already been carried too far in that direction. She too was a lover of solitude and wrote her letters to him in the stillness of the night, when all others were asleep. There can be no doubt that she had at least some share in determining his mental activity, especially his reading. In one of his earliest letters to her he writes: "Weil Du den Don Carlos liest, will

2 Werke, Vol. II, p. 86. 
ich ihn auch lesen." It was during this time too that that he became so ardent an admirer of Schubart and Ossian. "Da leg' ich meinen Ossian weg und komme zu Dir," he writes in I788 to his friend Nast. "Ich habe meine Seele geweidet an den Helden des Barden, habe mit ihm getrauert, wann er trauert über sterbende Mädchen."' There is not a sensuous note in all Hölderlin's poems or letters to Louise. Typical are the lines which he addresses to her on his departure from Maulbronn:

Lass sie drohen, die Stürme, die Leiden,

Lass trennen-der Trennung Jahre

Sie trennen uns nicht!

Sie trennen uns nicht!

Denn mein bist du! Und über das Grab hinaus

Soll sie dauren, die unzertrennbare Liebe.

$\mathrm{O}$ ! wenn's einst da ist

Das grosse selige Jenseits,

Wo die Krone dem leidenden Pilger,

Die Palme dem Sieger blinkt,

Dann Freundin-lohnet auch Freundschaft-

Auch Freundschaft der Ewige. ${ }^{3}$

The second bearing which his relations to Louise have upon his Weltschmerz lies in the fact that his love ended in disappointment. This is true not only of this particular episode, not only of all his love-affairs, but it may even be said that disappointment was the fate to which he found himself doomed in all his aspirations. And in the persistency with which this evil angel pursued his footsteps through life may be found one of the chief causes of the early collapse of his faculties. What David Müller ${ }^{4}$ and Hermann Fischer ${ }^{5}$ have said in their essays in regard to this point-that Hölderlin did not become insane because his life was a succession of unsatisfactory situations and painful disappointments, but because he had not the strength to work himself out of these situations into more favorable ones-states only half the case. True, a stronger

1 Briefe, p. 49.

2 Briefe, p. 50.

Werke, Vol. I, p. 74.

4 "Friedrich Hölderlin, Eine Studie," Preuss. Jahrb., I866, p. 548-568.

'Anz. f. d. Altertum, Vol. 22, p. 212-218. 
mental organization might have overcome these or even greater difficulties; Schiller, Herder, Fichte are examples; but not all of Hölderlin's failures and disappointments were the result of his weakness, and so while it is right to state that a stronger and more robust nature would have conquered in the fight, it is also fair to say that Hölderlin would have had a good chance of winning, had fortune been more kind. For this reason these external influences must be reckoned with as an important cause of his Weltschmerz and subsequently of his insanity.

This suggests an interesting point of comparison-if I may be permitted to anticipate somewhat-with Lenau, the second type selected. Hölderlin earnestly pursued happiness and contentment, but it eluded him at every step. Lenau on the contrary reached a point in his Weltschmerz where he refused to see anything in life but pain, wilfully thrusting from him even such happiness as came within his reach.

We may postpone any detailed reference to Hölderlin's relations with Susette Gontard, which were vastly more important in their influence upon the poet's character and Weltschmerz, until we come to the discussion of his "Hyperion," of which Susette, under the pseudonym of Diotima, forms one of the central figures.

To speak of all the disappointments which fell to Hölderlin's lot would practically require the writing of his biography from the time of his graduation from Tübingen to his return from Bordeaux, almost the entire period of his sane manhood. Unsuccessful in his first position as a tutor, and unable, after having abandoned this, to provide even a meagre living for himself with his pen, his migration to Frankfort to the house of the merchant Gontard at last gave him a hope of better things, but a hope which soon proved vain. Following close upon these disappointments was his failure to carry out a project which he had long cherished, of establishing a literary journal; then came his dismissal from a situation which he had just entered upon in Switzerland. On his return he wrote to Schiller for help and advice, and his failure to receive a reply grieved him deeply. We can only surmise that it was a cruel 
disappointment, finally, which caused his sudden departure from Bordeaux, and brought him back a mental wreck to his mother's home. Even as early as 1788 Hölderlin complains bitterly in the poem "Der Lorbeer," in which he eulogizes the poets Klopstock and Young and expresses his own ambition to aspire to their greatness:

\section{Schon so manche Früchte schöner Keime Logen grausam mir ins Angesicht. ${ }^{2}$}

As the years passed, this feeling of disappointment and disillusion became more and more intense and bitter. A stanza from one of his more mature poems (I795) "An die Natur," will serve to illustrate the sentiment which pervades almost all his writings :

Tot ist nun, die mich erzog und stillte,

Tot ist nun die jugendliche Welt,

Diese Brust, die einst ein Himmel füllte,

Tot und dürftig wie ein Stoppelfeld;

Ach es singt der Frühling meinen Sorgen

Noch, wie einst, ein freundlich tröstend Lied,

Aber hin ist meines Lebens Morgen,

Meines Herzens Frühling ist verblüht. ${ }^{2}$

In close causal connection with Hölderlin's Weltschmerz is his belief that his life is ruled by an inexorable fate whose plaything he is. "Wenn hinfort mich das Schicksal ergreift, und von einem Abgrund in den andern mich wirft, und alle Kräfte in mir ertränkt und alle Gedanken," Hyperion exclaims. ${ }^{3} \mathrm{He}$ goes even further, and conceives the idea of a sacrifice to Fate. Thus he makes Alabanda say near the close of "Hyperion:" "Ach! weil kein Glück ist ohne Opfer, nimm als Opfer mich, o Schicksal an, und lass die Liebenden in ihrer Freude." ${ }_{4}$ Wilhelm Scherer calls attention to Gervinus' remark that new intellectual tendencies which call for unaccustomed and unusual mental effort often prove disastrous to single individuals, and says: "Hölderlin war also ein Opfer der Erneuerung des deutschen Lebens-seltsam, wie der Gedanke des Opfers als

${ }^{1}$ Werke, Vol. I, p. 75.

2 'Werke, Vol. I, p. 146.

${ }^{3}$ Werke, Vol. II, p. 107.

${ }^{4}$ Werke, Vol. II, p. 188. 
ein hoher und herrlicher ihn in allen seinen Gedichten viel beschäftigt hat." ${ }_{1}$ But the poet does not apply this fatalism only to himself, to the individual; he widens its influence to humanity in general. "Wir sprechen von unserm Herzen, unsern Planen, als wären sie unser," says Hyperion, "und es ist doch eine fremde Gewalt, die uns herumwirft und ins Grab legt, wie es ihr gefällt, und von der wir nicht wissen, von wannen sie kommt, noch wohin sie geht:"'2 Perhaps nowhere better than in Hyperion's "Schicksalslied" does he give poetic expression to this thought. Omitting the first stanza it reads thus:

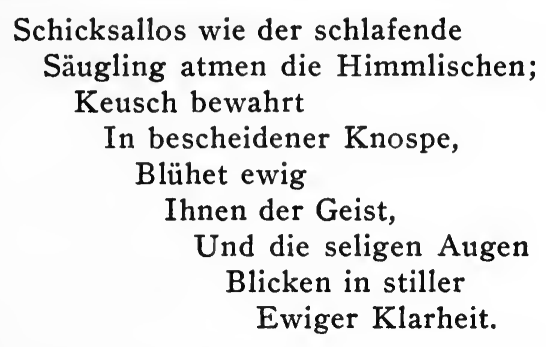

Doch uns ist gegeben,

Auf keiner Stätte zu ruhn,

Es schwinden, es fallen

Die leidenden Menschen

Blindlings von einer

Stunde zur andern,

Wie Wasser von Klippe

$\mathrm{Zu}$ Klippe geworfen,

Jahrlang ins Ungewisse hinab. ${ }^{3}$

The fundamental difference between Hölderlin's "Anschauung” and Goethe's is at once apparent when we recall the "Lied der Parzen" from "Iphigenie." Hölderlin does not bring the blessed Genii into any relation with mortals, but merely contrasts their free and blissful existence, emphasizing their immunity from Fate, to which suffering humanity is subject. But this humanity is represented by Hölderlin characteristically as helpless, passive-“"schwinden," "fallen," "blindlings von einer Stunde zur andern." Whereas the opening lines of Goethe's

1 "Vorträge und Aufsätze," I874, Fried. Hölderlin, p. 354.

2 Werke, Vol. II, p. 96.

${ }^{8}$ Werke, Vol. II, p. 189. 
"Parzen" strike the keynote of conflict between the gods and men:

\author{
Es fürchte die Götter \\ Das Menschengeschlecht! \\ Sie halten die Herrschaft \\ In ewigen Händen \\ Und können sie brauchen \\ Wie's ihnen gefällt. \\ Der fürchte sie doppelt, \\ Den je sie erheben!
}

And those who come to grief at the hands of the gods, are not weak passive creatures, but heaven-scaling Titans. This points to the antipodal difference between the characters of these two poets, and explains in part why Goethe did not succumb to the sickly sentimentalism of which he rid himself in "Werther." The difference between yielding and striving resulted in the difference between an acute case of Weltschmerz in the one and a healthy physical and intellectual manhood in the other.

Thus far it has been almost entirely the personal aspect of Hölderlin's Weltschmerz and its causes that has come under our notice. And since he was a lyric poet, it is perhaps natural that the sorrows which concerned him personally should find most frequent expression in his verse. But notwithstanding the fact that this personal element is very prominent in Hölderlin's writings, Scherer's judgment is correct when he states: "Die Grundstimmung war eine tiefe Verbitterung gegen die

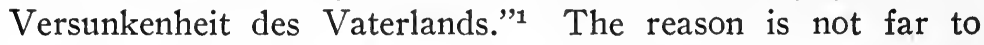
seek, especially when we consider the impossible demands of the poet's extravagant idealism. The conditions in Germany which had called forth the terrible arraignment of petty despotism, crushing militarism, and political rottenness generally, in the works of Lenz, Klinger and Schubart, had not abated. Schubart was one of Hölderlin's earliest favorites, so that the latter was doubtless in this way imbued with sentiments which could only grow stronger under the influence of his more mature observations and experiences. Even in his eighteenth year, in a poem "An die Demut," he gives expression in strong

${ }^{1}$ Cf. op. cit., p. $35^{2}$.

2 Werke, Vol. I, p. 5 I. 
terms to his patriotic feelings, in which his disgust with his faint-hearted, servile compatriots and his defiance of "Fürstenlaune" and "Despotenblut" are plainly evident. So too in "Männerjubel," I788:

Es glimmt in uns ein Funke der Göttlichen!

Und diesen Funken soll aus der Männerbrust

Der Hölle Macht uns nicht entreissen!

Hört es, Despotengerichte, hört es! ${ }^{1}$

Perhaps nowhere outside of his own Württemberg could he have been more unfavorably situated in this respect. Under Karl Eugen (1744-I793) the country sank into a deplorable condition. Regardless of the rights of individuals and communities alike, he sought in the early part of his reign to replenish his depleted purse by the most shameless measures, in order that he might surround himself with luxury and indulge his autocratic proclivities. Among his most reprehensible violations of constitutional rights, were his bartering of privileges and offices and the selling of troops. These things Hölderlin attacks in one of his youthful poems "Die Ehrsucht" (I788) :

Um wie Könige zu prahlen, schänden

Kleine Wütriche ihr armes Land;

Und um feile Ordensbänder wenden

Räte sich das Ruder aus der Hand. ${ }^{2}$

Another act of gross injustice which this petty tyrant perpetrated, and which Hölderlin must have felt very painfully, was the incarceration of the poet's countryman Schubart from I777 to 1787 in the Hohenasperg. But not only from within came tyrannous oppression. Following upon the coalition against France after the Revolution, Württemberg became the scene of bloody conflicts and the ravages of war. Under the régime of Friedrich Eugen (1795-97) the French gained such a foothold in Württemberg that the country had to pay a contribution of four million gulden to get rid of them. These were the conditions under which Hölderlin grew up into young manhood. But deeper than in the mere existence of these conditions themselves lay the cause of the poet's most abject humiliation and grief. It was the stoic indifference, the servile submission

1 Werke, Vol. I, p. 50.

${ }^{2}$ Werke, Vol. I. p. 49. 
with which he charged his compatriots, that called forth his bitterest invectives upon their insensible heads. His own words will serve best to show the intensity of his feelings. In I788 he writes, in the poem "Am Tage der Freundschaftsfeier:"
$\mathrm{Da}$ sah er (der Schwärmer) all die Schande
Der weichlichen Teutonssöhne,
Und fluchte dem verderblichen Ausland
Und fluchte den verdorbenen Affen des Auslands,
Und weinte blutige Thränen,
Dass er vielleicht noch lange
Verweilen müsse unter diesem Geschlecht. ${ }^{2}$

Ten years later he treats the Germans to the following ignominious comparison:

Spottet ja nicht des Kinds, wenn es mit Peitsch' und Sporn

Auf dem Rosse von Holz, mutig und gross sich dünkt.

Denn, ihr Deutschen, auch ihr seid

Thatenarm und gedankenvol1. ${ }^{2}$

With his friend Sinclair, who was sent as a delegate, he attended the congress at Rastatt in November, 1798 , and here he made observations which no doubt resulted in the bitter characterization of his nation in the closing letters of Hyperion. This convention, whose chief object was the compensation of those German princes who had been dispossessed by the cessions to France on the left bank of the Rhine, afforded a spectacle so humiliating that it would have bowed down in shame a spirit even less proud and sensitive than Hölderlin's. The French emissaries conducted themselves like lords of Germany, while the German princes vied with each other in acts of servility and submission to the arrogant Frenchmen. And it was the apathy of the average German, as Hölderlin conceived it, toward these and other national indignities, that caused him to put such bitter words of contumely into the mouth of $\mathrm{Hy}$ perion: "Barbaren von Alters her, durch Fleiss und Wissenschaft und selbst durch Religion barbarischer geworden, tief unfähig jedes göttlichen Gefühls-beleidigend für jede gut geartete Seele, dumpf und harmonielos, wie die Scherben eines weggeworfenen Gefässes-das, mein Bellarmin! waren meine

${ }^{1}$ Werke, Vol. I, p. 66.

${ }^{2}$ Werke, Vol. I, p. I65. 
Tröster." In another letter Hyperion explains their incapacity for finer feeling and appreciation when he writes: "Neide die Leidensfreien nicht, die Götzen von Holz, denen nichts mangelt, weil ihre Seele so arm ist, die nichts fragen nach Regen und Sonnenschein, weil sie nichts haben, was der Pflege bedürfte. Ja, ja, es ist recht sehr leicht, glücklich, ruhig zu sein mit seichtem Herzen und eingeschränktem Geiste."'2 Their work he characterizes as "Stümperarbeit," and their virtues as brilliant evils and nothing more. There is nothing sacred, he claims, that has not been desecrated by this nation. But it is chiefly his own experience which he recites, when, in speaking of the sad plight of German poets, of those who still love the beautiful, he says: "Es ist auch herzzerreissend, wenn man eure Dichter, eure Künstler sieht-die Guten, sie leben in der Welt, wie Fremdlinge im eigenen Hause."3 Still more extravagantly does the poet caricature his own people when he writes: "Wenn doch einmal diesen Gottverlassnen einer sagte, dass bei ihnen nur so unvollkommen alles ist, weil sie nichts Reines unverdorben, nichts Heiliges unbetastet lassen mit den plumpen Händen-dass bei ihnen eigentlich das Leben schaal und sorgenschwer ist, weil sie den Genius verschmähen-und darum fürchten sie auch den Tod so sehr, und leiden um des Austernlebens willen alle Schmach, weil Höhres sie nicht kennen, als ihr Machwerk, das sie sich gestoppelt."4

But we should get an extremely unjust and one-sided idea of Hölderlin's attitude toward his country from these quotations alone. The point which they illustrate is his growing estrangement from his own people, which in the very nature of the case must have had an important bearing upon his Weltschmerz. But his feelings in regard to Germany and the Germans were not all contempt. In many of his poems there is the true patriotic ring. It is true, we can nowhere find any clear political program, neither could we expect one from a poet who was so absorbed in his own feelings, and whose ideals soared so high above the sphere of practical politics. In this too Höld-

\footnotetext{
1 Werke, Vol. II, p. 198.

2 Werke, Vol. II, p. 97.

Werke, Vol. II, p. 200.

Werke, Vol. II, p. $200 \mathrm{f}$.
} 
erlin was the product of previous influences. With all their clamor for political upheavals, the "Stürmer und Dränger" never arrived at any serious or practical plan of action. Notwithstanding all this, the word Vaterland was always an inspiration to Hölderlin, and it is especially gratifying to note that the calumny which he heaps upon the devoted heads of the Germans is not his last word on the subject. Nor did he ever lose sight of his lofty ideal of liberty for his degraded fatherland or cease to hope for its realization. In this strain he concludes the "Hymne an die Freiheit" (I790) with a splendid outburst of patriotic enthusiasm:

\footnotetext{
Dann am süssen, heisserrung'nen Ziele, Wenn der Ernte grosser Tag beginnt, Wenn verödet die Tyrannenstühle, Die Tyrannenknechte Moder sind, Wenn im Heldenbunde meiner Brüder Deutsches Blut und deutsche Liebe glüht, Dann, O Himmelstochter! sing ich wieder, Singe sterbend dir das letzte Lied. ${ }^{1}$
}

What a remarkable change is noticeable in the tone which the poet assumes toward his country in the lines "Gesang des Deutschen," written in I799, probably after the completion of his "Hyperion":

O heilig Herz der Völker, O Vaterland!

Allduldend gleich der schweigenden Muttererd'

Und allverkannt, wenn schon aus deiner

Tiefe die Fremden ihr Bestes haben.

$\mathrm{Du}$ Land des hohen, ernsteren Genius!

Du Land der Liebe! bin ich der Deine schon,

Oft zürnt' ich weinend, dass du immer

Blöde die eigene Seele leugnest. ${ }^{2}$

How much the reproach has been softened, and with what tender regard he strives to mollify his former bitterness! To this change in his feelings, his sojourn in strange places and the attendant discouragements and disappointments seem to have contributed not a little, for in the poem "Rückkehr in die

1 Werke, Vol. I, p. 105.

${ }^{2}$ Werke, Vol. I, p. 196. 
Heimat," written in I800, the contempt of "Hyperion" has been replaced by compassion. He sees himself and his country linked together in the sacred companionship of suffering, consequently it can no longer be the object of his scorn.

\section{Wie lange ist's, $O$ wie lange! des Kindes Ruh' Ist hin, und hin ist Jugend, und Lieb' und Glück, Doch du, mein Vaterland! du heilig \\ Duldendes! siehe, du bist geblieben. ${ }^{1}$}

But the fact remains, nevertheless, that Hölderlin from his early youth felt himself a stranger in his own land and among his own people. Some of the causes of this circumstance have already been discussed. The fact itself is important because it establishes the connection between his Weltschmerz and his most noteworthy characteristic as a poet, namely, his Hellenism. No other German poet has allowed himself to be so completely dominated by the Greek idea as did Hölderlin. And in his case it may properly be called a symptom of his Weltschmerz, for it marks his flight from the world of stern reality into an imaginary world of Greek ideals. An imaginary Greek world, because in spite of his Hellenic enthusiasm he entertained some of the most un-Hellenic ideas and feelings.

That the poet should take refuge in Greek antiquity is not surprising, when we consider the conditions which prevailed at that time in the field of learning. It was not many decades since the study of Latin and Roman institutions had been forced to yield preeminence of position in Germany to the study of Greek. Furthermore, his own Suabia had come to be recognized as a leader in the study of Greek antiquity, and in his contemporaries Schiller, Hegel, Schelling, who were all countrymen and acquaintances of his, he found worthy competitors in this branch of learning. His fondness for the language and literature of Greece goes back to his early school days, especially at Denkendorf and Maulbronn. On leaving the latter school, he had the reputation among his fellow-students of being an excellent Hellenist, according to the report of Schwab, his biographer. It was while there that Hölderlin as a boy

${ }^{1}$ Werke, Vol. I, p. 214. 
of seventeen first made use of the Alcaic measure in which he subsequently wrote so many of his poems.

A full discussion of the technic of Hölderlin's poems would have so remote a connection with the main topic under consideration that its introduction here would be entirely out of place. It will suffice, therefore, merely to indicate along broad lines the extent to which the Greek idea took and held possession of the poet.

Out of his 168 shorter poems, 126 , exactly three-fourths, are written in the unrhymed Greek measures. ${ }^{1}$ Those forms which are native are confined almost entirely to his juvenile and youthful compositions, and after I797 he only once employs the rhymed stanza, namely, in the poem "An Landauer." a boy of sixteen, he wrote verses in the Alcaic and Asclepiadeian measures, ${ }^{3}$ and soon acquired a considerable mastery over them. At seventeen he composed in the latter form his poem "An meine Freundinnen:"

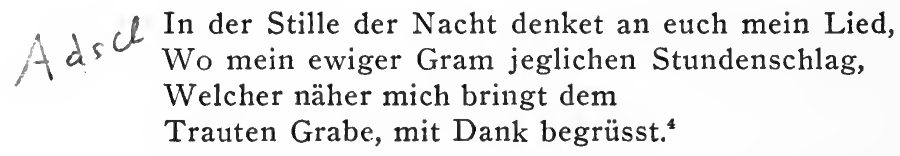

While not exhibiting the finish of expression and musical qualities of his more mature Alcaic lyrics, still it is not bad poetry for a boy of seventeen, and the reader feels what the boy was not slow to learn, that the stately movement of the Greek stanzas lends an added dignity to the expression of sorrow, which was to constitute so large a part of his poetic activity. As already stated, the Alcaic measure was of all the Greek verse-forms Hölderlin's favorite, and the one most frequently and successfully employed by him. He is very fond of introducing Germanic alliteration into these unrhymed stanzas, as the following example will illustrate:

Und wo sind Dichter, denen der Gott es gab,

Wie unsern Alten, freundlich und fromm zu sein,

${ }^{1}$ Werke, Vol. I.

${ }^{2}$ Werke, Vol. I, p. 234.

s "An die Nachtigall," "An meinen Bilfinger," Werke, Vol. I, p. ${ }_{22} \mathrm{f}$.

${ }^{4}$ Werke, Vol. I, p. 43. 
Wo Weise, wie die unsern sind, die

Kalten und Kühnen, die unbestechbarn? ? $^{1}$

The Asclepiadeian stanza he employs much less frequently, the Sapphic only once, and that with indifferent success. It was the ode, dithyramb and hymn, the serious lyric, which Hölderlin selected as the models for his poetic fashion. In this purpose he was not alone, for his friend Neuffer writes to him in I793, with an enthusiasm which in the intensity of expression common at the time, seems almost like an inspiration: "Die höhere Ode und der Hymnus, zwei in unsern Tagen, und vielleicht in allen Zeitaltern am meisten vernachlässigte Musen! in ihre Arme wollen wir uns werfen, von ihren Küssen beseelt uns aufraffen. Welche Aussichten! Dein Hymnus an die Kühnheit mag Dir zum Motto dienen! Mir gehe die Hoffnung voran.",

But it was in the form much more than in the contents of his poems, that Hölderlin carried out the Greek idea. Most of his lyrics are occasional poems, or have abstract subjects, as for example, "An die Stille," "An die Ehre," "An den Genius der Kühnheit," and so on. Only here and there does he take a classic subject or introduce classic references. The truth of the matter is, that with all his fervid enthusiasm for Hellenic ideals, and with all his Greek cult, Hölderlin was not the genuine Hellenist he thought himself to be. This is due to the fact that his turning to Greece was in its final analysis attributable rather to selfish than to altruistic motives. He wanted to get away from the deplorable realities about him, the things which hurt his tender soul, and so he constructed for himself this idealized world of ancient and modern Greece, and peopled it with his own creations.

In Hölderlin's "Hyperion," we have the first poetic work in German which takes modern Greece as its locality and a modern Hellene as its hero. Hölderlin calls it "ein Roman," but it would be rather inaccurately described by the usual translation of that term. It is not only the poetic climax of his Hellenism, but also the most complete expression of his Welt-

1 Werke, Vol. I, p. 197.

: Briefe, p. 160 . 
schmerz in its various phases. It must naturally be both, for the poet and the hero are one. He speaks of it as "mein Werkchen, in dem ich lebe und webe."1 Its subject is the emancipation of Greece. What little action is narrated may be very briefly indicated. Russia is at war with Turkey and calls upon Hellas to liberate itself. The hero and his friend Alabanda are at the head of a band of volunteers, fighting the Turks. After several minor successes Hyperion lays siege to the Spartan fortress of Misitra. But at its capitulation, he is undeceived concerning the Hellenic patriots; they ravage and plunder so fiercely that he turns from them with repugnance and both he and Alabanda abandon the cause of liberty which they had championed. To his bride Hyperion had promised a redeemed Greece-a lament is all that he can bring her. She dies, Hyperion comes to Germany where his aesthetic Greek soul is severely jarred by the sordidness, apathy and insensibility of these "barbarians." Returning to the Isthmus, he becomes a hermit and writes his letters to Bellarmin, no less "thatenarm und gedankenvoll" himself than his unfortunate countrymen whom he so characterizes. ${ }^{2}$

"Hyperion," though written in prose, is scarcely anything more than a long drawn out lyric poem, so thoroughly is action subordinated to reflection, and so beautiful and rhythmic is the dignified flow of its periods. But having said that the locality is Greece and its hero is supposed to be a modern Greek, that in its scenic descriptions Hölderlin produces some wonderfully natural effects, and that the language shows the imitation of Greek turns of expression-Homeric epithets and simileshaving said this, we have mentioned practically all the Greek characteristics of the composition. And there is much in it that is entirely un-Hellenic. To begin with, the form in which "Hyperion" is cast, that of letters, written not even during the progress of the events narrated, but after they are all a thing of the past, is not at all a Greek idea. Moreover Weltschmerz, which constitutes the "Grundstimmung" of all Hölderlin's writings, and which is most plainly and persistently expressed

${ }^{1}$ Briefe, p. 162.

${ }^{2}$ Cf. supra, p. 22. 
in "Hyperion," is not Hellenic. Not that we should have to look in vain for pessimistic utterances from the classical poets of Greece-for does not Sophocles make the deliberate statement: "Not to be born is the most reasonable, but having seen the light, the next best thing is to go to the place whence we came as soon as possible." ${ }_{1}$ Nevertheless, this sort of sentiment cannot be regarded as representing the spirit of the ancient Greeks, which was distinctly optimistic. They were happy in their worship of beauty in art and in nature, and above all, happy in their creativeness. The question suggests itself here, whether a poet can ever be a genuine pessimist, since he has within him the everlasting impulse to create. And to create is to hope. Hyperion himself says: "Es lebte nichts, wenn es nicht hoffte."' But we have already distinguished between pessimism as a system of philosophy, and Weltschmerz as a poetic mood. ${ }^{3}$ It is certainly un-Hellenic that Hölderlin allows Hyperion with his alleged Greek nature to sink into contemplative inactivity.

In the poem "Der Lorbeer," I789, he exclaims :

Soll ewiges Trauern mich umwittern,

Ewig mich töten die bange Sehnsucht?"

which gives expression to the fact that in his Weltschmerz there was a very large admixture of "Sehnsucht," an entirely un-Hellenic feeling. Nor is there to be found in his entire make-up the slightest trace of Greek irony, which would have enabled him to overcome much of the bitterness of his life, and which might indeed have averted its final catastrophe.

Undeniably Grecian is Hölderlin's idea that the beautiful is also the good. Long years he sought for this combined ideal. In Diotima, the muse of his "Hyperion," whose prototype was Susette Gontard, he has found it-and now he feels that he is in a new world. To his friend Neuffer, from whom he has no secrets, he writes: "Ich konnte wohl sonst glauben, ich wisse, was schön und gut sei, aber seit ich's sehe, möcht' ich lachen über all mein Wissen. Lieblichkeit und Hoheit, und Ruh und

1 Edipus Coloneus," 1225 seq.

2 Werke, Vol. II, p. 8I.

${ }^{3} \mathrm{Cf}$. Introduction, p. I $\mathrm{f}$.

4 Werke, Vol. I, p. 89. 
Leben, und Geist und Gemüt und Gestalt ist Ein seeliges Eins in diesem Wesen." 1 And six or eight months later: "Mein Schönheitsinn ist nun vor Störung sicher. Er orientiert sich ewig an diesem Madonnenkopfe. . . . Sie ist schön wie Engel! Ein zartes, geistiges, himmlisch reizendes Gesicht! Ach ich könnte ein Jahrtausend lang mich und alles vergessen bei ihrMajestät und Zärtlichkeit, und Fröhlichkeit und Ernst-und Leben und Geist, alles ist in und an ihr $\mathrm{zu}$ einem göttlichen Ganzen vereint." ${ }^{2}$ It would be difficult to conceive of a more complete and sublime eulogy of any object of affection than the words just quoted, and yet they do not conceal their author's etherial quality of thought, his "Uebersinnlichkeit." Even his boyish love-affairs seem to have been largely of this character, and were in all likelihood due to the necessity which he felt of bestowing his affection somewhere, rather than to irresistible forces proceeding from the objects of his regard.

Lack of self-restraint, so often characteristic of the poet of Weltschmerz, was not Hölderlin's greatest fault. And yet if his intense devotion to Susette remained undebased by sensual desires, as we know it did, this was not solely due to the practice of heroic self-restraint, but must be attributed in part to the fact that that side of his nature was entirely subordinate to his higher ideals; and these were always a stronger passion with Hölderlin than his love. So that Diotima's judgment of Hyperion is correct when she says : "O es ist so ganz natürlich, dass $\mathrm{Du}$ nimmer lieben willst, weil Deine grössern Wünsche verschmachten."' This consideration at once compels a comparison with Lenau, which must be deferred, however, until the succeeding chapter. Undoubtedly this year and a half at Frankfurt was the happiest period of his whole life. It brought him a serenity of mind which he had never before known. Ardent was the response called forth by his devotion, but its influence was wholesome-it was soothing to his sensitive nerves. And because it was altogether more a sublime than an earthly passion, he indulged himself in it with a con-

1 Briefe, p. $382 \mathrm{f}$.

2 Briefe, p. 403-405.

${ }^{3}$ Werke, Vol. II, p. 175. 
science void of offence. Doubtless he correctly describes the influence of his relations with Diotima upon his life when he writes: "Ich sage Dir, lieber Neuffer! ich bin auf dem Wege, ein recht guter Knabe zu werden. . . . mein Herz ist voll Lust, und wenn das heilige Schicksal mir mein glücklich Leben erhält, so hoff' ich künftig mehr zu thun als bisher."' But the happy life was not to continue long. Rudely the cup was dashed from his lips, and the poet's pain intensified by one more disappointment-the bitterest of all he had experienced. It filled him with thoughts of revenge, which he was powerless to execute. There can be no question that if his love for Susette had been of a less etherial order, less a thing of the soul, he would have felt much less bitterly her husband's violent interference.

But returning to the poem "Hyperion," for as such we may regard it, we find in it the most complete expression of the attitude which the poet, in his Weltschmerz, assumed toward nature. Nature is his constant companion, mother, comforter in sorrow, in his brighter moments his deity. This natureworship, which speedily develops into a more or less consistent pantheism, Hölderlin expresses in Hyperion's second letter, in the following creed: "Eines zu sein mit allem, was lebt, in seliger Selbstvergessenheit wiederzukehren ins All der Natur, das ist der Gipfel der Gedanken und Freuden, das ist die heilige Bergeshöhe, der Ort der ewigen Ruhe." ${ }^{2}$ And so nature is to Hölderlin always intensely real and personal. The sea is youthful, full of exuberant joy; the mountain-tops are hopeful and serene; with shouts of joy the stream hurls itself like a giant down into the forests. Here and there his personification of nature becomes even more striking: "O das Morgenlicht und ich, wir gingen uns entgegen, wie versöhnte Freunde."3 Still more intense is this feeling of personal intimacy, when he exclaims: "O selige Natur! ich weiss nicht, wie mir geschiehet, wenn ich mein Auge erhebe von deiner Schöne, aber alle Lust des Himmels ist in den Thränen, die ich weine vor dir, der Geliebte vor der Geliebten." ${ }_{4}$ It is important for purposes of

1 Briefe, p. 404.

2 Werke, Vol. II, p. 68.

${ }^{3}$ Werke, Vol. II, p. 100.

4 Werke, Vol. II, p. 68. 
comparison, to note that notwithstanding his intense Weltschmerz, in his treatment of nature Hölderlin does not select only its gloomy or terrible aspects. Light and shade alternate in his descriptions, and only here and there is the background entirely unrelieved. The thunderstorm is to him a dispenser of divine energies among forest and field, even the seasons of decline and decay are not left without sunshine: "auf der stummen entblätterten Landschaft, wo der Himmel schöner als je, mit Wolken und Sonnenschein um die herbstlich schlafenden Bäume spielte." 1 One passage in "Hyperion" bears so striking a resemblance, however, to Lenau's characteristic nature-pictures, that it shall be given in full-although even here, when the gloom of his sorrow and disappointment was steadily deepening, he does not fail to derive comfort from the warm sunshine, a thought for which we should probably look in vain, had Lenau painted the picture: "Ich sass mit Alabanda auf einem Hügel der Gegend, in lieblich wärmender Sonn', und um uns spielte der Wind mit abgefallenem Laube. Das Land war stumm; nur hie und da ertönte im Wald ein stürzender Baum, vom Landmann gefällt, und neben uns murmelte der vergängliche Regenbach hinab ins ruhige Meer."2

In spite of his deep and persistent Weltschmerz, Hölderlin rarely gives expression to a longing for death. This forms so prominent a feature in the thought of other types of Weltschmerz, for instance of Lenau and of Leopardi, that its absence here cannot fail to be noticed. It is true that in his dramatic poem "Der Tod des Empedokles," which symbolizes the closing of his account with the world, Hölderlin causes his hero to return voluntarily to nature by plunging into the fiery crater of Mount Etna. But Empedokles does this to atone for past sin, not merely to rid himself of the pain of living; and thus, even as a poetic idea, it impresses us very differently from the continual yearning for death which pervades the writings of the two poets just mentioned. Leopardi declared that it were best never to see the light, but denounced suicide as a cowardly act of selfishness; and yet at the approach of an epi-

1 Werke, Vol. II, p. 85.

2 Werke, Vol. II, p. I 8 I. 
demic of cholera, he clung so tenaciously to life that he urged a hurried departure from Naples, regardless of the hardships of such a journey in his feeble condition, and took refuge in a little villa near Vesuvius. Hölderlin's Weltschmerz was absolutely sincere.

Numerous passages might be quoted to show that Hölderlin's mind was intensely introspective. This is true also of Lenau, even to a greater extent, and may be taken as generally characteristic of poets of this type. The fact that this introspection is an inevitable symptom in many mental derangements, hypochondria, melancholia and others, indicates a not very remote relation of Weltschmerz to insanity. In Hölderlin's poems there are not a few premonitions of the sad fate which awaited him. One illustration from the poem "An die Hoffnung," I801, may suffice:

Wo bist du? wenig lebt' ich, doch atmet kalt

Mein Abend schon. Und stille, den Schatten gleich,

Bin ich schon hier; und schon gesanglos

Schlummert das schau'rende Herz im Busen. ${ }^{1}$

It is impossible to read these lines without feeling something of the cold chill of the heart that Hölderlin felt was already upon him, and which he expresses in a manner so intensely realistic and yet so beautiful.

Having thus attempted a review of the growth of Hölderlin's Weltschmerz and of its chief characteristics, it merely remains to conclude the chapter with a brief résumé. We have then in Friedrich Hölderlin a youth peculiarly predisposed to feel himself isolated from and repelled by the world, growing up without a strong fatherly hand to guide, giving himself over more and more to solitude and so becoming continually less able to cope with untoward circumstances and conditions. Growing into manhood, he was unfortunate in all his love-affairs and as though doomed to unceasing disappointments. Early in life he devoted himself to the study of antiquity, making Greece his hobby, and thus creating for himself an ideal world which existed only in his imagination, and taking refuge in it from the buffetings of the world about him. He was

1 Werke, Vol. I, p. 253. 
a man of a deeply philosophical trend of mind, and while not often speaking of it, felt very keenly the humiliating condition of Germany, although his patriotic enthusiasm found its artistic expression not with reference to Germany but to Greece. As a poet, finally, his intimacy with nature was such that nature-worship and pantheism became his religion.

In reviewing the whole range of Hölderlin's writings, we cannot avoid the conclusion, that in him we have a type of Weltschmerz in the broadest sense of the term; we might almost term it Byronism, with the sensual element eliminated. He shows the hypersensitiveness of Werther, fanatical enthusiasm for a vague ideal of liberty, vehement opposition to existing social and political conditions; there is, in fact, a breadth in his Weltschmerz, which makes the sorrows of Werther seem very highly specialized in comparison. Bearing in mind the distinction made between the two classes, we must designate Hölderlin's Weltschmerz as cosmic rather than egoistic; the egoistic element is there, but it is outweighed by the cosmic and finds its poetic expression not so frequently nor so intensely with reference to the poet himself, as with reference to mankind at large. 


\section{CHAPTER III}

\section{Lenau}

If Hölderlin's Weltschmerz has been fittingly characterized as idealistic, Lenau's on the other hand may appropriately be termed the naturalistic type. $\mathrm{He}$ is par excellence the "Pathetiker" of Weltschmerz.

Without presuming even to attempt a final solution of a problem of pathology concerning which specialists have failed to agree, there seems to be sufficient circumstantial as well as direct evidence to warrant the assumption that Lenau's case presents an instance of hereditary taint. Notwithstanding the fact that Dr. Karl Weiler" discredits the idea of "erbliche Belastung" and calls heredity "den vielgerittenen Verlegenheitsgaul," the conclusion forces itself upon us that if the theory has any scientific value whatsoever, no more plausible instance of it could be found than the one under consideration. The poet's great-grandfather and grandfather had been officers in the Austrian army, the latter with some considerable distinction. Of his five children, only Franz, the poet's father, survived. The complete lack of anything like a systematic education, and the nomadic life of the army did not fail to produce the most disastrous results in the wild and dissolute character of the young man. Even before the birth of the poet, his father had broken his marriage vows and his wife's heart by his abominable dissipations and drunkenness. Lenau was but five years old when his father, not yet thirty-five, died of a disease which he is believed to have contracted as a result of these sensual and senseless excesses. To the poet he bequeathed something of his own pathological sensuality, instability of thought and action, lack of will-energy, and the tears of a heart-

${ }^{1}$ Euphorion, 1899, p. 791. 
broken mother, a sufficient guarantee, surely, of a poet of melancholy. Even though we cannot avoid the reflection that the loss of such a father was a blessing in disguise, the fact remains that Lenau during his childhood and youth needed paternal guidance and training even more than did Hölderlin. He became the idol of his mother, who in her blind devotion did not hesitate to show him the utmost partiality in all things. This important fact alone must account to a large extent for that presumptuous pride, which led him to expect perhaps more than his just share from life and from the world.

Lenau's aimlessness and instability were so extreme that they may properly be counted a pathological trait. It is best illustrated by his university career. In I8I9 he went to Vienna to commence his studies. Beginning with Philosophy, he soon transferred his interests to Law, first Hungarian, then German; finding the study of Law entirely unsuited to his tastes, he now declared his intention of pursuing once more a philosophical course, with a view to an eventual professorship. But this plan was frustrated by his grandmother, the upshot of it all being that Lenau allowed himself to be persuaded to take up the study of agriculture at Altenburg. But a few months sufficed to bring him back to Vienna. Here his legal studies, which he had resumed and almost completed, were interrupted by a severe affection of the throat which developed into laryngitis and from which he never quite recovered. This too, according to Dr. Sadger, ${ }^{1}$ marks the neurasthenic, and often constitutes a hereditary taint. Lenau thereupon shifted once more and entered upon a medical course, this time not absolutely without predilection. He did himself no small credit in his medical examinations, but the death of his grandmother, just before his intended graduation, provided a sufficient excuse for him to discontinue the work, which was never again resumed or brought to a conclusion. But not only in matters of such relative importance did Lenau exhibit this vacillation. There was a spirit of restlessness in him which made it impossible for him to remain long in the same place. Of this condition no one was more fully aware than he himself. In one of 
his letters he writes: "Gestern hat jemand berechnet, wieviel Poststunden ich in zwei Monaten gefahren bin, und es ergab sich die kolossale Summe von 644, die ich im Eilwagen unter beständiger Gemütsbewegung gefahren bin." That this habit of almost incessant travel tended to aggravate his nervous condition is a fair supposition, notwithstanding the fact that Dr. Karl Weiler" skeptically asks "what about commercial travellers?" Lenau himself complains frequently of the distressing effect of such journeys: "Ein heftiger Kopfschmerz und grosse Müdigkeit waren die Folgen der von Linz an unausgesetzten Reise im Eilwagen bei schlechtem Wetter und abmüdenden Gedanken an meine Zukunft."3 Many similar statements might be quoted from his letters to show that it was not merely the ordinary process of traveling, though that at best must have been trying enough, but the breathless haste of his journeys, combined with mental anxiety, which usually characterized them, that made them so detrimental to his health.

It is as interesting as it is significant to note in this connection the fact that while on a journey to Munich, just a short time before the light of his intellect failed, Lenau wrote the following lines, the last but one of all his poems :

's ist eitel nichts, wohin mein Aug' ich hefte!

Das Leben ist ein vielbesagtes Wandern,

Ein wüstes Jagen ist's von dem zum andern,

Und unterwegs verlieren wir die Kräfte.

Doch trägt uns eine Macht von Stund zu Stund, Wie's Krüglein, das am Brunnenstein zersprang, Und dessen Inhalt sickert auf den Grund, So weit es ging, den ganzen Weg entlang,Nun ist es leer. Wer mag daraus noch trinken? Und $z u$ den andern Scherben muss es sinken."

Hölderlin also uses the striking figure contained in the last line, not however as here to picture the worthlessness of human

1 Schurz, Vol. II, p. 212.

${ }^{2}$ Cf. Euphorion, 1899, p. 795.

'Anton Schurz: "Lenau's Leben," Cotta, 1855 (hereafter quoted as "Schurz"), Vol. II, p. 199.

“"Lenaus Werke," ed Max Koch, in Kürschner's DNL. (hereafter quoted as "Werke"), Vol. I, p. 525 f. 
life in general, but to stigmatize the Germans, whom Hyperion describes as "dumpf und harmonielos, wie die Scherben eines weggeworfenen Gefässes."1

That Lenau was a neurasthenic seems to be the consensus of opinion, at least of those medical authorities who have given their views of the case to the public. ${ }^{2}$ This fact also has an important bearing upon our discussion, since it will help to show a materially different origin for Lenau's Weltschmerz and Hölderlin's.

Much more frequent than in the case of the latter are the ominous forebodings of impending disaster which characterize Lenau's poems and correspondence. In a letter to his friend Karl Mayer he writes: "Mich regiert eine Art Gravitation nach dem Unglücke. Schwab hat einmal von einem Wahnsinnigen sehr geistreich gesprochen. ... Ein Analogon von solchem Dämon (des Wahnsinns) glaub' ich auch in mir zu beherbergen."'3 $\mathrm{He}$ is continually engaged in a gruesome selfdiagnosis: "Dann ist mir zuweilen, als hielte der Teufel seine Jagd in dem Nervenwalde meines Unterleibes: ich höre ein deutliches Hundegebell daselbst und ein dumpfes Halloh des Schwarzen. Ohne Scherz; es ist oft zum Verzweifeln."4 This process of self-diagnosis may be due in part to his medical studies, but much more, we think, to his morbid imagination, which led him, on more than one occasion, to play the madman in so realistic a manner that strangers were frightened out of their wits and even his friends became alarmed, lest it might be earnest and not jest which they were witnessing.

Lenau was not without a certain sense of humor, grim humor though it was, and here and there in his letters there is an admixture of levity with the all-pervading melancholy. An example may be quoted from a letter to Kerner in Weinsberg, dated 1832: "Heute bin ich wieder bei Reinbecks auf ein grosses Spargelessen. Spargel wie Kirchthürme werden da gefressen. Ich allein verschlinge 50-60 solcher Kirchthürme

1 Cf. supra, p. 22.

${ }^{2} \mathrm{Cf}$. among others Sadger, Weiler. Infra, p. 88.

3 "Nicolaus Lenau's Briefe an einen Freund," Stuttgart, 1853, p. 68 f.

4 "Nicolaus Lenau's sämmtliche Werke," herausgegeben von G. Emil Barthel, Leipzig, Reclam, p. CI. 
und komme mir dabei vor, wie eine Parodie unserer politischprosaischen, durchaus unheiligen Zeit, die auch schon das Maul aufsperrt, um alles Heilige, und namentlich die guten gläubigen Kirchthürme wie Spargelstangen zu verschlingen.” The letter concludes with the signature: "Ich umarme Dich, bis Dir lie Rippen krachen. Dein Niembsch."1 Not infrequently this humor was at his own expense, especially when describing an unpleasant condition or situation, as for example in a letter to Sophie Löwenthal in the year I844: "Jetzt lebe ich hier in Saus und Braus,- $d$. h. es saust und braust mir der Kopf von einem leidigen Schnupfen."'2 Again, on finding himself on one occasion very unwell and uncomfortable in Stuttgart, he writes as follows: "Beständiges Unwohlsein, Kopfschmerz, Schlaflosigkeit, Mattigkeit, schlechte Verdauung, Rhabarber, Druckfehler, und Aerger über den trägen Fortschlich meiner Geschäfte, das waren die Freuden meiner letzten Woche. Emilie will es nicht gelten lassen, dass die Stuttgarter Luft nichts als die Ausdünstung des Teufels sei.Ich schnappe nach Luft, wie ein Spatz unter der Luftpumpe.In vielen der hiesigen Strassen riecht es am Ende auch lenzhaft, nämlich pestilenzhaft, und die guten Stuttgarter merken das gar nicht; 'süss duftet die Heimat." ", In his fondness for bringing together the incongruous, for introducing the element of surprise, and in the fact that his humor is almost always of the impatient, disgruntled, cynical type, Lenau reminds us not a little of Heine in his "Reisebilder" and some other prose works. Hölderlin, on the other hand, may be said to have been utterly devoid of humor.

Lack of self-control, perhaps the most characteristic trait among men of genius, was even more pronounced in Lenau than in Hölderlin. This shows itself in the extreme irregularity of his habits of life. For instance, it was his custom to work long past the midnight hour, and then take his rest until nearly noon. He could never get his coffee quite strong enough to suit him, although it was prepared almost in the

${ }^{1}$ Schurz, Vol. I, p. 169.

2 Schurz, Vol. II, p. 144.

${ }^{3}$ Schurz, Vol. II, p. I52f. 
form of a concentrated tincture and he drank large quantities of it. He smoked to excess, and the strongest cigars at that; in short, he seems to have been entirely without regard for his physical condition. Or was it perverseness which prompted him to prefer close confinement in his room to the long walks which he ought to have taken for his health? Even his recreation, which consisted chiefly in playing the violin, brought him no nervous relaxation, for it is said that he would often play himself into a state of extreme nervous excitement.

All these considerations corroborate the opinion of those who knew him best, that his Weltschmerz, and eventually his insanity, had its origin in a pathological condition. Indeed this was the poet's own view of the case. In a letter to his brother-in-law, Anton Schurz, dated 1834, he says: "Aber, lieber Bruder, die Hypochondrie schlägt bei mir immer tiefere Wurzel. Es hilft alles nichts. Der gewisse innere Riss wird immer tiefer und weiter. Es hilft alles nichts. Ich weiss, es liegt im Körper; aber-aber-"' In its origin then, Lenau's Weltschmerz differs altogether from that of Hölderlin, who exhibits no such symptoms of neurasthenia.

Lenau's nervous condition was seriously aggravated at an early date by the outcome of his unfortunate relations with the object of his first love, Bertha, who became his mistress when he was still a mere boy. His grief on finding her faithless was doubtless as genuine as his conduct with her had been reprehensible, for he cherished for many long years the memory of his painful disappointment. The general statement, "Lenau war stets verlobt, fand aber stets in sich selbst einen Widerstand und unerklärliche Angst, wenn die Verbindung endgiltig gemacht werden sollte," ${ }^{\prime 2}$ is inaccurate and misleading, inasmuch as it fails to take into proper account the causes, mediate and immediate, of his hesitation to marry. Lenau was only once "verlobt," and it was the stroke of facial paralysis ${ }^{3}$ which announced the beginning of the end, rather than any "un-

${ }^{1}$ Schurz, Vol. I, p. 275.

${ }^{2}$ Ricarda Huch: "Romantische Lebensläufe." Neue d. Rundschau, Feb. 1902, p. 126.

${ }^{3}$ Sept. 29 , 1844. Cf. Schurz, Vol. II, p. 223. 
erklärliche Angst," that convinced him of the inexpediency of that important step.

Beyond a doubt his long drawn out and abject devotion to the wife of his friend Max Löwenthal proved the most important single factor in his life. It was during the year I834, after his return from America, that Lenau made the acquaintance of the Löwenthal family in Vienna. ${ }^{1}$ Sophie, who was the sister of his old comrade Fritz Kleyle, so attracted the poet that he remained in the city for a number of weeks instead of going at once to Stuttgart, as he had planned and promised. What at first seemed an ideal friendship, increased in intensity until it became, at least on Lenau's part, the very glow of passion. We have already alluded to the poet's premature erotic instinct, an impulse which he doubtless inherited from his sensual parents. In his numerous letters and notes to Sophie, he has left us a remarkable record of the intensity of his passion. Not even excepting Goethe's letters to Frau von Stein, there are no love-letters in the German language to equal these in literary or artistic merit; and never has any other German poet addressed himself with more ardent devotion to a woman. A characteristic difference between Hölderlin and Lenau here becomes evident: the former, even in his relations with Diotima, supersensual; the latter the very incarnation of sensuality. Lenau was fully conscious of the tremendous struggle with overpowering passion, and once confessed to his clerical friend Martensen that only through the unassailable chastity of his lady-love had his conscience remained void of offence. Almost any of his innumerable protestations of love taken at random would seem like the most extravagant attempt to give utterance to the inexpressible: "Gottes starke Hand drückt mich so fest an Dich, dass ich seufzen muss und ringen mit erdrückender Wonne, und meine Seele keinen Atem mehr hat, wenn sie nicht Deine Liebe saugen kann. Ach Sophie! ach, liebe, liebe, liebe Sophie!"2 "Ich bete Dich an, Du bist mein Liebstes und Höchstes.",

\footnotetext{
1L. A. Frankl: "Lenau und Sophie Löwenthal," Stuttgart, 1891 (hereafter quoted as "Frankl") p. 189 , incorrectly states the date as 1838 . Possibly it is a misprint.

${ }^{2}$ Frankl, p. 155 .

${ }^{8}$ Frankl, p. I51.
} 
“Am sechsten Juni reis' ich ab, nichts darf mich halten. Mir brennt Leib und Seele nach Dir. Du! O Sophie! Hätt' ich Dich da! Das Verlangen schmerzt, O Gott!"' Instead of experiencing the soothing influences of a Diotima, Lenau's fate was to be engaged for ten long years in a hot conflict between principle and passion, a conflict which kept his naturally oversensitive nerves continually on the rack. He himself expresses the detrimental effect of this situation: "So treibt mich die Liebe von einer Raserei zur andern, von der zügellosesten Freude zu verzweifeltem Unmut. Warum? Weil ich am Ziel der höchsten, so heiss ersehnten Wonne immer wieder umkehren muss, weil die Sehnsucht nie gestillt wird, wird sie irr und wild und verkehrt sich in Verzweiflung,-das ist die Geschichte meines Herzens." ${ }^{2}$ It would seem from the tone of many of his letters that there was much deliberate and successful effort on the part of Sophie to keep Lenau's feelings toward her always in a state of the highest nervous tension. So cleveriy did she manage this that even her caprices put him only the more hopelessly at her mercy. One day he writes: "Mit grosser Ungeduld erwartete ich gestern die Post, und sie brachte mir auch einen Brief von Dir, aber einen, der mich kränkt."3 For a day or two he is rebellious and writes: "Ich bin verstimmt, missmutig. Warum störst $\mathrm{Du}$ mein Herz in seinen schönen Gedanken von innigem Zusammenleben auch in der Ferne?"4 But only a few days later he is again at her feet: "Ich habe Dir heute wieder geschrieben, um Dich auch zum Schreiben zu treiben. Ich sehne mich nach Deinen Briefen. Du bist nicht sehr eifrig, Du bist es wohl nie gewesen. Und kommt endlich einmal ein Brief, so hat er meist seinen Haken-O liebe Sophie! wie lieb' ich Dich!'” Her attitude on several occasions leaves room for no other inference than that she was extremely jealous of his affections. When in I839 a mutual regard sprang up between Lenau and the singer Karoline Unger, a regard which held out to him the hope of a fuller and

\footnotetext{
1 Frankl, p. I64.

2 Frankl, p. 102.

${ }^{8}$ Frankl, p. 149.

4 Frankl, p. I 50.

- Frankl, p. 150.
} 
happier existence, we may surmise the nature of Sophie's interference from the following reply to her: "Sie haben mir mit Ihren paar Zeilen das Herz zerschmettert,-Karoline liebt mich und will mein werden. Sie sieht's als ihre Sendung an, mein Leben $\mathrm{zu}$ versöhnen und $\mathrm{zu}$ beglücken.-Es ist an Ihnen Menschlichkeit zu üben an meinem zerrissenen Herzen.-Verstosse ich sie, so mache ich sie elend und mich zugleich.Entziehen Sie mir Ihr Herz, so geben Sie mir den Tod; sind Sie unglücklich, so will ich sterben. Der Knoten ist geschürzt. Ich wollte, ich wäre schon tot!'” Not only was this proposed match broken off, but when some five years later Lenau made the acquaintance of and became engaged to a charming young girl, Marie Behrends, and all the poet's friends rejoiced with him at the prospect of a happy marriage, a "Musterehe," as he fondly called it, Sophie wrote him the cruel words: "Eines von uns muss wahnsinnig werden.", Only a few months were needed to decide which of them it should be.

The foregoing illustrations are ample to show what sort of influence Sophie exerted over the poet's entire nature, and therefore upon his Weltschmerz. Whereas in their hopeless loves, Hölderlin and to an even greater extent Goethe, struggled through to the point of renunciation, Lenau constantly retrogrades, and allows his baser sensual instincts more and more to control him. He promises to subdue his wild outbursts a little, ${ }^{3}$ and when he fails he tries to explain, ${ }^{4}$ to apologize. $^{5}$ If with Hölderlin love was to a predominating degree a thing of the soul, it was with Lenau in an equal measure a matter of nerves, and as such, under these conditions, it could not but contribute largely to his physical, mental and moral disruption. With Hölderlin it was the rude interruption from without of his quiet and happy intercourse with Susette, which embittered his soul. With Lenau it was the feverish, tumultuous nature of the love itself, that deepened his melancholy.

1 Schurz, Vol. II, p. 7.

${ }^{2}$ Cf. Lenau's Sämmtl. Werke, herausg. von G. Emil Bartel, Leipzig, ohne Jahr. Introd., p. clxv.

${ }^{3}$ Frankl, p. 32.

4 Frankl, p. 14.

S Frank1, p. 30 . 
The charge of affectation in their Weltschmerz would be an entirely baseless one, both in the case of Hölderlin and Lenau. But this difference is readily discovered in the impressions made upon us by their writings, namely that Hölderlin's Weltschmerz is absolutely naive and unconscious, while that of Lenau is at all times self-conscious and self-centered. Mention has already been made, in speaking of Lenau's pathological traits, ${ }^{1}$ of his confirmed habit of self-diagnosis. This he applied not only to his physical condition but to his mental experiences as well. No one knew so well as he how deeply the roots of melancholy had penetrated his being. "Ich bin ein Melancholiker" he once wrote to Sophie, "der Kompass meiner Seele zittert immer wieder zurück nach dem Schmerze des Lebens." 2 Innumerable illustrations of this fact might be found in his lyrics, all of which would repeat with variations the theme of the stanza:

Du geleitest mich durch's Leben

Sinnende Melancholie!

Mag mein Stern sich strebend heben,

Mag er sinken,-weichest nie! ${ }^{8}$

The definite purpose with which the poet seeks out and strives to keep intact his painful impressions is frankly stated in one of his diary memoranda, as follows: "So gibt es eine Höhe des Kummers, auf welcher angelangt wir einer einzelnen Empfindung nicht nachspringen, sondern sie laufen lassen, weil wir den Blick für das schmerzliche Ganze nicht verlieren, sondern eine gewisse kummervolle Sammlung behalten wollen, die bei aller scheinbaren Aussenheiterkeit recht gut fortbestehen kann." ${ }_{4}$ Hölderlin, as we have noted, ${ }^{5}$ not infrequently pictures himself as a sacrifice to the cause of liberty and fatherland, to the new era that is to come:

Umsonst zu sterben, lieb' ich nicht; doch

Lieb' ich zu fallen am Opferhügel

Für's Vaterland, zu bluten des Herzens Blut,

Für's Vaterland ....

${ }^{1}$ Cf. supra, p. 38.

${ }^{2}$ Frankl, p. 15.

${ }^{3}$ Werke, I, p. 89.

4 Frankl, p. ir 4 .

'Cf. supra, p. 18.

${ }^{6}$ Hölderlins Werke, Vol. I, p. 195. 
Lenau, on the other hand, is anxious to sacrifice himself to his muse. "Künstlerische Ausbildung ist mein höchster Lebenszweck; alle Kräfte meines Geistes, meines Gemütes betracht' ich als Mittel dazu. Erinnerst $\mathrm{Du}$ Dich des Gedichtes von Chamisso, ${ }^{1}$ wo der Maler einen Jüngling ans Kreuz nagelt, um ein Bild vom Todesschmerze $\mathrm{zu}$ haben? Ich will mich selber ans Kreuz schlagen, wenn's nur ein gutes Gedicht gibt."2 And again: "Vielleicht ist die Eigenschaft meiner Poesie, dass sie ein Selbstopfer ist, das Beste daran."3 The specific instances just cited, together with the inevitable impressions gathered from the reading of his lyrics, make it impossible to avoid the conclusion that we are dealing here with a virtuoso of Weltschmerz; that Lenau was not only conscious at all times of the depth of his sorrow, but that he was also fully aware of its picturesqueness and its poetic possibilities. It is true that this self-consciousness brings him dangerously near the bounds of insincerity, but it must also be granted that he never oversteps those bounds.

Regarded as a psychological process, Lenau's Weltschmerz therefore stands midway between that of Hölderlin and Heine. It is more self-centred than Hölderlin's and while the poet is able to diagnose the disease which holds him firmly in its grasp, he lacks those means by which he might free himself from it. Heine goes still further, for having become conscious of his melancholy, he mercilessly applies the lash of self-irony, and in it finds the antidote for his Weltschmerz.

Fichte, says Erich Schmidt, calls egoism the spirit of the eighteenth century, by which he means the revelling, the complete absorption, in the personal. This will naturally find its favorite occupation in sentimental self-contemplation, which becomes a sort of fashionable epidemic. It is this fashion which Goethe wished to depict in "Werther," and therefore Werther's hopeless love is not wholly responsible for his suicide. "Werther untergräbt sein Dasein durch Selbstbetrachtung," is Goethe's own explanation of the case." And it is in

1 "Das Kruzifix, Eine Künstlerlegende," I820.

2 Schurz, Vol. I, p. $158 f$.

8 Schurz, Vol. II, p. 6.

"Cf. Breitinger: "Studien und Wandertage;" Frauenfeld, Huber, 1870. 
this light only that Werther's malady deserves in any comprehensive sense the term Weltschmerz. Here, then, Lenau and Werther stand on common ground. Other traits common to most poets of Weltschmerz might here be enumerated as characteristic of both, such as extreme fickleness of purpose, supersensitiveness, lack of definite vocation, and the like; all of which goes to show that while for artistic purposes Goethe required a dramatic cause, or rather occasion, for Werther's suicide, he nevertheless fully understood all the symptoms of the prevailing disease with which his sentimental hero was afflicted.

While the personal elements in Lenau's Weltschmerz are much more intense in their expression than with Hölderlin, its altruistic side is proportionately weaker. So far as we may judge from his lyrics, very little of Lenau's Weltschmerz was inspired by patriotic considerations. There is opposition, it is true, to the existing order, but that opposition is directed almost solely against that which annoyed and inconvenienced him personally, for example, against the stupid as well as rigorous Austrian censorship. Against this bugbear he never ceases to storm in verse and letters, and to it must be attributed in a large measure his literary alienation from the land of his adoption. That we must look to his lyrics rather than to his longer epic writings, in order to discover the poet's deepest interests, is nowhere more clearly evidenced than in the following reference to his "Savonarola," in a letter to Emilie Reinbeck during the progress of the work: "Savonarola wirkte zumeist als Prediger, darum muss ich in meinem Gedicht ihn vielfach predigen und dogmatisieren lassen, welches in vierfüssigen doppeltgereimten Iamben sehr schwierig ist. Doch es freut mich, Dinge poetisch durchzusetzen, an deren poetischer Darstellbarkeit wohl die meisten Menschen verzweifeln. Auch gereicht es mir zu besonderem Vergnügen, mit diesem Gedicht gegen den herrschenden Geschmack unseres Tages in Opposition zu treten." ${ }_{1}$ The inference lies very near at hand that his opposition to the prevailing taste was after all a secondary consideration, and that the poet's first concern was to win glory

\footnotetext{
${ }^{1}$ Schlossar: "Nicolaus Lenaus Briefe an Emilie von Reinbeck," Stuttgart, I896 (hereafter quoted as "Schlossar"), p. 98.
} 
by accomplishing something which others would abandon as an impossibility. While recognizing the fact that Lenau's "Faust" and "Don Juan" are largely autobiographical, it is, I think, obvious that an entirely adequate impression of his Weltschmerz may be gained from his letters and lyrics alone, in which the poet's sincerest feelings need not be subordinated for a moment to artistic purposes or demands. And nowhere, either in lyrics or letters, do we find such spontaneous outbursts of patriotic sentiment as greet us in Hölderlin's poems :

Glückselig Suevien, meine Mutter!

This could not be otherwise ; for was he (Lenau) not an Hungarian by birth, an Austrian by adoption, and in his professional affiliations a German? Had his interests not been divided between Vienna and Stuttgart, and had he not been possessed with an apparently uncontrollable restlessness which drove him from place to place, his patriotic enthusiasm would naturally have turned to Austria, and the poetic expression of his home sentiments would not have been confined, perhaps, to the one occasion when he had put the broad Atlantic between himself and his kin. That his brother-in-law Schurz should wish to represent him as a dyed-in-the-wool Austrian is only natural. ${ }^{2}$ However this may be, the poet does not hesitate to state in a letter to Emilie Reinbeck: "Ein Hund in Schwaben hat mehr Achtung für mich als ein Polizeipräsident in Oesterreich."3 And although he professes to have become hardened to the pestering interference of the authorities, as a matter of fact it was a constant source of unhappiness to him. "So aber war mein Leben seit meinem letzten Briefe ein beständiger Aerger. Die verfluchten Vexationen der hiesigen Censurbehörde haben selbst jetzt noch immer kein Ende finden können."4 Speaking of his hatred for the censorship law, he says: "Und doch gebührt mein Hass noch immer viel weniger dem Gesetze selbst, als denjenigen legalisierten Bestien, die das Gesetz auf eine so niederträchtige Art handhaben;-und unsre Censoren stellen im Gegensatze der pflanzen- und fleischfressenden Tiere

1 Werke, Vol. II, p. 260.

2 Schurz, Vol. II, p. 193.

8 Schlossar, p. 109.

Schlossar, p. III. 
die Klasse der geistfressenden Tiere dar, eine abscheuliche, monströse Klasse!" 1 Roustan expresses the opinion that with Lenau patriotism occupied a secondary place. $^{2} \mathrm{He}$ had too many "native lands" to become attached to any one of them.

There is something of a counterpart to Hölderlin's Hellenism and championship of Greek liberty in Lenau's espousal of the Polish cause. But here again the personal element is strongly in evidence. A chance acquaintance, which afterward became an intimate friendship, with Polish fugitives, seems to have been the immediate occasion of his Polenlieder, so that his enthusiasm for Polish liberty must be regarded as incidental rather than spontaneous. Needless to say that with a Greek cult such as Hölderlin's Lenau had no patience whatever. "Dass die Poesie den profanen Schmutz wieder abwaschen müsse, den ihr Goethe durch 50 Jahre mit klassischer Hand gründlich einzureiben bemüht war; dass die Freiheitsgedanken, wie sie jetzt gesungen werden, nichts seien als konventioneller Trödel,- -davon haben nur wenige eine Ahnung."'3

All these considerations tend to convince us that Lenau's Weltschmerz is after all of a much narrower and more personal type than Hölderlin's. Again and again he runs through the gamut of his own painful emotions and experiences, diagnosing and dissecting each one, and always with the same gloomy result. Consequently his Weltschmerz loses in breadth what through the depth of the poet's introspection it gains in intensity.

One of the most striking and, unless classed among his numerous other pathological traits, one of the most puzzling of Lenau's characteristics is the perverseness of his nature. His intimate friends were wont to explain it, or rather to leave it unexplained by calling it his "Husarenlaune" when the poet would give vent to an apparently unprovoked and unreasonable burst of anger, and on seeing the consternation of those present, would just as suddenly throw himself into a fit of laughter quite as inexplicable as his rage. He takes delight

\footnotetext{
${ }^{1}$ Schlossar, p. $112 \mathrm{f}$.

2 "Lenau et son Temps," Paris, I898, p. 35 I.

${ }^{3}$ Schlossar, p. 103.
} 
in things which in the ordinarily constructed mind would produce just the reverse feeling. Speaking once of a particularly ill-favored person of his acquaintance he says: "Eine so gewaltige Hässlichkeit bleibt ewig neu und kann sich nie abnützen. Es ist was Frisches darin, ich sehe sie gerne." ${ }_{1}$ And in not a few of his poems we see a certain predilection for the gruesome, the horrible. So in the remarkable figure employed in "Faust:"

\section{Die Träume, ungelehr'ge Bestien, schleichen}

Noch immer nach des Wahns verscharrten Leichen. ${ }^{2}$

This perverseness of disposition is in a large measure accounted for by the fact that Lenau was eternally at war with himself. Speaking in the most general way, Hölderlin's Weltschmerz had its origin in his conflict with the outer world, Lenau's on the other hand must be attributed mainly to the unceasing conflict or "Zwiespalt" within his breast. In his childhood a devout Roman Catholic, he shows in his "Faust" (I833-36) a mind filled with scepticism and pantheistic ideas; "Savonarola" ( 1837 ) marks his return to and glorification of the Christian faith; while in the "Albigenser" (1838-42) the poet again champions complete emancipation of thought and belief. Only a few months elapsed between the writing of the two poems "Wanderung im Gebirge" ( 1830 ), in which the most orthodox faith in a personal God is expressed, and "Die Zweifler" (I831). The only consistent feature of his poems is their profound melancholy. But Lenau's inner struggle of soul did not consist merely in his vacillating between religious faith and doubt; it was the conflict of instinct with reason. This is evident in his relations with Sophie Löwenthal. He knows that their love is an unequal one ${ }^{3}$ and chides her for her coldness, ${ }^{4}$ warning her not to humiliate him, not even in jest ${ }^{5}$ he knows too that his alternating moods of exaltation and dejection resulting from the intensity of his unsatisfied love are de-

1 Schlossar, p. 154.

2 Werke, Vol. II, p. 183.

${ }^{3}$ Frankl, p. 99.

4 Frank1, p. 90.

- Frankl, p. 90. 
stroying him. ${ }^{1}$ "Oetter hat sich der Gedanke bei mir angemeldet: Entschlage dich dieser Abhängigkeit und gestatte diesem Weibe keinen so mächtigen Einfluss auf deine Stimmungen. Kein Mensch auf Erden soll dich so beherrschen. Doch bald stiess ich diesen Gedanken wieder zurück als einen Verräter an meiner Liebe, und ich bot mein reizbares Herz wieder gerne dar Deinen zärtlichen Misshandlungen.-O geliebtes Herz! missbrauche Deine Gewalt nicht! Ich bitte Dich, liebe Sophie!"' And yet, in spite of it all, he is unable to free himself from the thrall of passion: "Wie wird doch all mein Trotz und Stolz so gar zu nichte, wenn die Furcht in mir erwacht, dass Du mich weniger liebest" ; 3 and all this from the same pen that once wrote: "das Wort Gnade hat ein Schuft erfunden." 4

But just as helpless as this defiant pride proved before his all-consuming love for Sophie, so strongly did it assert itself in all his other relations with men and things. A hasty word from one of his best friends could so deeply offend his spirit that, according to his own admission, all subsequent apologies were futile. ${ }^{5}$ For Lenau, then, such an attitude of heroworship as that assumed by Hölderlin towards Schiller, would have been an utter impossibility. We have already seen the extent to which he was over-awed (?) by Goethe's views when they were at variance with their own. ${ }^{6}$ On another occasion he writes: "Was Goethe über Ruysdael faselt, kannte ich bereits." "T Toward his critics his bearing was that of haughty indifference: "Mag auch das Talent dieser Menchen, mich $\mathrm{zu}$ insultieren, gross sein, mein Talent, sie zu verachten, ist auf alle Fälle grösser." ${ }^{2}$ When his Frühlingsalmanach of 1835 had been received with disfavor by the critics, he professed to be concerned only for his publisher: "Ich meinerseits habe auf Liebe und Dank nie gezählt bei meinen Bestrebungen."॰

\footnotetext{
1 Frank1, p. 192.

2 Frankl, p. 173.

${ }^{3}$ Frankl, p. 103.

4 Schlossar, p. 55.

- Cf. Schlossar, p. 93 f.

${ }^{6}$ Cf. supra, p. 48.

- Schlossar, p. 46.

8 Schlossar, p. 85 .

- Schlossar, p. 83 .
} 
"Die (Recensenten) wissen den Teufel von Poesie."1 Whether this real or assumed nonchalance would have stood the test of literary disappointments such as Hölderlin's, it is needless to speculate.

Hölderlin eagerly sought after happiness and contentment, but fortune eluded him at every turn. Lenau on the contrary thrust it from him with true ascetic spirit.

The mere thought of submitting to the ordinary process of negotiations and recommendations for a vacant professorship of Esthetics in Vienna is so repulsive to his pride, that the whole matter is at once allowed to drop, notwithstanding that he has been preparing for the place by diligent philosophical studies. $^{2}$ The asceticism with which he regarded life in general is expressed in a letter to Emilie Reinbeck, 1843 , in which he says: "Wer die Welt gestalten helfen will, muss darauf verzichten, sie zu geniessen." 3 But more often this resignation becomes a defiant challenge: "Ich habe dem Leben gegenüber nun einmal meine Stellung genommen, es soll mich nicht hinunterkriegen. Dass mein Widerstand nicht der eines ruhigen Weisen ist, sondern viel Trotziges an sich hat, das liegt in meinen Temperament."

Another characteristic difference between Lenau's Weltschmerz and Hölderlin's lies in the fact that the writings of the latter do not exhibit that absolute and abject despair which marks Lenau's lyrics. Typical for both poets are the lines addressed by each to a rose:

Ewig trägt im Mutterschosse,

Süsse Königin der Flur,

Dich und mich die stille, grosse,

Allbelebende Natur.

Röschen unser Schmuck veraltet, Sturm entblättert dich und mich, Doch der ew'ge Keim entfaltet Bald zu neuer Blüte sich!

${ }^{1}$ Schurz, Vol. I, p. 176.

${ }^{2}$ Cf. Schlossar, p. 173 .

3 Schlossar, p. 184.

4 Schlossar, p. 87.

'Hölderlin, "An eine Rose," Werke, Vol. I, p. 142. 
Unmistakable as is the melancholy strain of these verses, they are not without a hopeful afterthought, in which the poet turns from self-contemplation to a view of a larger destiny. Not so in Lenau's poem, "Welke Rosen":

In einem Buche blätternd, fand

Ich eine Rose welk, zerdrückt,

Und weiss auch nicht mehr, wessen Hand

Sie einst für mich gepflückt.

Ach mehr und mehr im Abendhauch

Verweht Erinn'rung; bald zerstiebt

Mein Erdenlos; dann weiss ich auch

Nicht mehr, wer mich geliebt. ${ }^{1}$

The intensely personal note of the last stanza is in marked contrast with the corresponding stanza of Hölderlin's poem just quoted. Further evidence that Lenau's Weltschmerz was constitutional, while Hölderlin's was the result of experience, lies in this very fact, that nowhere do the writings of the former exhibit that stage of buoyant expectation, youthful enthusiasm, or hopeful striving, which we find in some of the earlier poems of the latter. In Hölderlin's ode "An die Hoffnung," he apostrophizes hope as "Holde! gütig Geschäftige!"

Die du das Haus der Trauernden nicht verschmähst."

Lenau, in his poem of the same title, tells us he has done with hope:

\section{All dein Wort ist Windesfächeln; \\ Hoffnung! dann nur trau' ich dir, \\ Weisest du mit Trosteslächeln \\ Mir des Todes Nachtrevier. ${ }^{8}$}

Even his Faust gives himself over almost from the outset to abject despair.

Logically consequent upon this state of mind is the poet's oft-repeated longing for death. The persistency of this thought may be best illustrated by a few quotations from poems and letters, arranged chronologically:

1831. Mir wird oft so schwer, als ob ich einen Todten in mir herumtrüge. ${ }^{4}$

\footnotetext{
1 Werke, Vol. I, p. 389.

${ }^{2}$ Hölderlins Werke, Vol. I, p. 253.

${ }^{3}$ Werke, Vol. I, p. 99.

4 Schurz, Vol. I, p. I32.
} 
1833. Und mir verging die Jugend traurig,

Des Frühlings Wonne blieb versäumt,

Der Herbst durchweht mich trennungsschaurig,

Mein Herz dem Tod entgegenträumt. ${ }^{1}$

1837. Heute dachte ich öfter an den Tod, nicht mit bitterem Trotz und störrischem Verlangen, sondern mit freundlichem Appetit. $^{2}$

1837. Soll ich Dir alles sagen? Wisse, dass ich wirklich daran dachte, mir den Tod zu geben. ${ }^{3}$

1838. Der Gedanke des Todes wird mir immer freundlicher, und ich verschwende mein Leben gerne. ${ }^{4}$

I838. Durchs Fenster kommt ein dürres Blatt

Vom Wind hereingetrieben;

Dies leichte offne Brieflein hat

Der Tod an mich geschrieben. ${ }^{\circ}$

1840. Oft will mich's gemahnen, als hätte ich auf Erden nichts mehr $\mathrm{zu}$ thun, und ich wünschte dann, Gervinus möchte recht haben, indem er, wie Georg mir erzählte, mir einen baldigen Zusammenbruch und Tod prophezeite.

1842. Ich habe ein wollüstiges Heimweh, in Deinen Armen zu sterben. ${ }^{7}$

1843. Selig sind die Betäubten! noch seliger sind die Toten! $!^{\mathrm{s}}$

1844. In dieses Waldes leisem Rauschen

Ist mir, als hör' ich Kunde wehen,

Dass alles Sterben und Vergehen

Nur heimlichstill vergnügtes Tauschen. ${ }^{\circ}$

If we should seek for the Leit-motif of Lenau's Weltschmerz, we should unquestionably have to designate it as the transientness of life. Thus in the poem "Die Zweifler," he exclaims :

Vergänglichkeit! wie rauschen deine Wellen

Durch's weite Labyrinth des Lebens fort! ${ }^{10}$

Ten per cent. of all Lenau's lyrics bear titles which directly express or suggest this thought, as for example, "Vergangenheit," "Vergänglichkeit," "Das tote Glück," "Einst und Jetzt,"

1 Werke, Vol. I, p. 82.

2 Frankl, p. 79.

3 Frankl, p. 102.

4 Frankl, p. 127.

'Werke, Vol. I, p. 267.

- Schlossar, p. 144.

7 Frankl, p. 169.

8 Schlossar, p. 188.

- Werke, Vol. I, p. 405.

10 Werke, Vol. I, p. 130. 
"Aus!,” “Eitel Nichts," "Verlorenes Glück," "Welke Rose," "Vanitas," "Scheiden," "Scheideblick," and the like; while in not less than seventy-one per cent. of his lyrics there are allusions, more or less direct, to this same idea, which shows beyond a doubt how large a component it must have been of the poet's characteristic mood.

If Hölderlin, the idealist, judges the things which are, according to his standard of things as they ought to be, Lenau, on the other hand, measures them by the things which have been.

\section{Friedhof der entschlafnen Tage, \\ Schweigende Vergangenheit! \\ Du begräbst des Herzens Klage, Ach, und seine Seligkeit!}

Nowhere is this mental attitude of the poet toward life in all its forms more clearly defined than in his views of nature. That this is an entirely different one from Hölderlin's goes without saying. Lenau has nothing of that naive and unsophisticated childlike nature-sense which Hölderlin possessed, and which enabled him to find comfort and consolation in nature as in a mother's embrace. So that while for Hölderlin intercourse with nature afforded the greatest relief from his sorrows, Lenau's Weltschmerz was on the contrary intensified thereby. For him the rose has no fragrance, the sunlight no warmth, springtime no charms, in a word, nature has neither tone nor temper, until such has been assigned to it by the poet himself. And as he is fully aware of the artistic possibilities of the mantle of melancholy "um die wunde Brust geschlungen," 2 it follows consistently that he should select for poetic treatment only those aspects of nature which might serve to intensify the expression of his grief.

Among the titles of Lenau's lyrics descriptive of nature are "Herbst," "Herbstgefühl” (twice), "Herbstlied," "Ein Herbstabend," "Herbstentschluss," "Herbstklage," and many others of a similar kind, such as "Das dürre Blatt," "In der Wüste," "Frühlings Tod," etc. If we disregard a few quite excep-

1 Werke, Vol. I, p. 62.

2 Werke, Vol. I, p. ro2. 
tional verses on spring, the statement will hold that Lenau sees in nature only the seasons and phenomena of dissolution and decay. So in "Herbstlied" :

$\mathrm{Ja}$, ja, ihr lauten Raben, Hoch in der kühlen Luft, 's geht wieder ans Begraben, Ihr flattert um die Gruft! !

"Je mehr man sich an die Natur anschliesst," the poet writes to Sophie Schwab, "je mehr man sich in Betrachtungen ihrer Züge vertieft, desto mehr wird man ergriffen von dem Geiste der Sehnsucht, des schwermütigen Hinsterbens, der durch die Natur auf Erden weht." ${ }^{2}$ Characteristic is the setting which the poet gives to the "Waldkapelle":

Der dunkle Wald umrauscht den Wiesengrund,

Gar düster liegt der graue Berg dahinter,

Das dürre Laub, der Windhauch gibt cs kund.

Geschritten kommt allmählig schon der Winter.

Die Sonne ging, umhüllt von Wolken dicht, Unfreundlich, ohne Scheideblick von hinnen, Und die Natur verstummt, im Dämmerlicht

Schwermütig ihrem Tode nachzusinnen. ${ }^{3}$

The sunset is represented as a dying of the sun, the leaves fall sobbing from the trees, the clouds are dissolved in tears, the wind is described as a murderer. We see then that Lenau's treatment of nature is essentially different from Hölderlin's. The latter explains man through nature; Lenau explains nature through man. Hölderlin describes love as a heavenly plant, ${ }^{4}$ youth as the springtime of the heart, ${ }^{5}$ tears as the dew of love ; $;^{6}$ Lenau, on the other hand, characterizes rain as the tears of heaven, for him the woods are glad, ${ }^{7}$ the brooklet weeps, ${ }^{8}$ the air is idle, the buds and blossoms listen, ${ }^{9}$ the forest in its

1 Werke, Vol. I, p. 299.

2 Cf. Farinelli, in Verhandlungen des 8. deutschen Neuphilologentages, Hannover. 1898 , p. 58.

Werke, Vol. I, p. I37.

Höld. Werke, Vol. I, p. 167.

Höld. Werke, Vol. I, p. 143.

- Höld. Werke, Vol. I, p. 140.

Ten. Werke, Vol. I, p. 258.

${ }^{8}$ Len. Werke, Vol. I, p. 250.

- Len. Werke, Vol. I, p. 260. 
autumn foliage is "herbstlich gerötet, so wie ein Kranker, der sich neigt zum Sterben, wenn flüchtig noch sich seine Wangen färben."1 A remarkable simile, and at the same time characteristic for Lenau in its morbidness is the following:

Wie auf dem Lager sich der Seelenkranke, Wirft sich der Strauch im Winde hin und her. ${ }^{2}$

Hölderlin speaks of a friend's bereavement as "ein schwarzer Sturm"; 3 when he had grieved Diotima he compares himself to the cloud passing over the serene face of the moon $;^{4}$ gloomy thoughts he designates by the common metaphor "der Schatten eines Wölkchens auf der Stirne."' Lenau turns the comparison and says :

Am Himmelsantlitz wandelt ein Gedanke,

Die düstre Wolke dort, so bang, so schwer.

Where Hölderlin finds delight in the incorporeal elements of nature, such as light, ether, and ascribes personal qualities and functions to them, Lenau on the contrary always chooses the tangible things and invests them with such mental and moral attributes as are in harmony with his gloomy state of mind. Consequently Lenau's Weltschmerz never remains abstract; indeed, the almost endless variety of concrete pictures in which he gives it expression is nothing short of remarkable, not only in the sympathetic nature-setting which he gives to his lamentations, but also in the striking metaphors which he employs. Of the former, probably no better illustration could be found in all Lenau's poems than his well-known "Schilflieder"7 and his numerous songs to Autumn. One or two examples of his incomparable use of nature-metaphors in the expression of his Weltschmerz will suffice:

\footnotetext{
${ }^{1}$ Len. Werke, Vol. I, p. 249.

${ }^{2}$ Len. Werke, Vol. I, p. 147.

${ }^{3}$ Höld. Werke, Vol. I, p. I 44 .

${ }^{4}$ Höld. Werke, Vol. I, p. I64.

${ }^{5}$ Höld. Werke, Vol. II, p. I17.

${ }^{6}$ Len. Werke, Vol. I, p. 447.

${ }^{7}$ Werke, Vol. I, p. 5 I f.
} 
Hab' ich gleich, als ich so sacht

Durch die Stoppeln hingeschritten,

Aller Sensen auch gedacht,

Die ins Leben mir geschnitten. ${ }^{1}$

Auch mir ist Herbst, und leiser

Trag' ich den Berg hinab

Mein Bündel dürre Reiser

Die mir das Leben gab. ${ }^{2}$

Der Mond zieht traurig durch die Sphären,

Denn all die Seinen ruhn im Grab;

Drum wischt er sich die hellen Zähren

Bei Nacht an unsern Blumen $a b .^{3}$

The forceful directness of Lenau's metaphors from nature is aptly shown in the following comparison of two passages, one from Hölderlin's "An die Natur," the other from Lenau's "Herbstklage," in which both poets employ the same poetic fancy to express the same idea.

Tot ist nun, die mich erzog und stillte,

Tot ist nun die jugendliche Welt,

Diese Brust, die einst ein Himmel füllte,

Tot und dürftig wie ein Stoppelfeld."

If we compare the simile in the last line with the corresponding metaphor used by Lenau in the following stanza,-

Wie der Wind zu Herbsteszeit

Mordend hinsaust in den Wäldern,

Weht mir die Vergangenheit

Von des Glückes Stoppelfeldern,

the greater artistic effectiveness of the latter figure will be at once apparent.

The idea that nature is cruel, even murderous, as suggested in the opening lines of the stanza just quoted, seems in the course of time to have become firmly fixed in the poet's mind, for he not only uses it for poetic purposes, but expresses his conviction of the fact on several occasions in his conversations and letters. Tossing some dead leaves with his stick while out

1 "Der Kranich," Werke, Vol. I, p. 328.

2 "Herbstlied," Werke, Vol. I, p. 299.

8 "Mondlied," Werke, Vol. I, p. 3 ro.

1 Höld. Werke, Vol. I, p. 146.

$\checkmark$ Werke, Vol. I, p. 299. 
walking, he is said to have exclaimed: "Da seht, und dann heisst es, die Natur sei liebevoll und schonend! Nein, sie ist grausam, sie hat kein Mitleid. Die Natur ist erbarmungslos !'1 It goes without saying that in such a conception of nature the poet could find no amelioration of his Weltschmerz. ${ }^{2}$

In summing up the results of our discussion of Lenau's Weltschmerz, it would involve too much repetition to mention all the points in which it stands, as we have seen, in striking contrast to that of Hölderlin. Suffice it to recall only the most essential features of the comparison: the predominance of hereditary and pathological traits as causative influences in the case of Lenau; the fact that whereas Hölderlin's quarrel was largely with the world, Lenau's was chiefly within himself; the passive and ascetic nature of Lenau's attitude, as compared with the often hopeful striving of Hölderlin; the patriotism of the latter, and the relative indifference of the former; Lenau's strongly developed erotic instinct, which gave to his relations with Sophie such a vastly different influence upon his Weltschmerz from that exerted upon Hölderlin by his relations with Diotima; and finally the marked difference in the attitude of these two poets toward nature.

A careful consideration of all the points involved will lead to no other conclusion than that whereas in Hölderlin the cosmic element predominates, Lenau stands as a type of egoistic Weltschmerz. To quote from our classification attempted in the first chapter, he is one of "those introspective natures who are first and chiefly aware of their own misery, and finally come to regard it as representative of universal evil." Nowhere is this more clearly stated than in the poet's own words: "Es hat etwas Tröstliches für mich, wenn ich in meinem Privatunglück den Familienzug lese, der durch alle Geschlechter der armen Menschen geht. Mein Unglück ist mir mein Liebstes,und ich betrachte es gerne im verklärenden Lichte eines allgemeinen Verhängnisses."3

\footnotetext{
1 Schurz, Vol. II, p. Io4.

${ }^{2}$ For an exhaustive discussion of Lenau's nature-sense cf. Prof. Camillo von Klenze's excellent monograph on the subject, "The Treatment of Nature in the Works of Nikolaus Lenau," Chicago, University Press, 1902.

Frank1, p. I 6 .
} 


\section{CHAPTER IV}

\section{Heine}

Heine was probably the first German writer to use the term Weltschmerz in its present sense. Breitinger in his essay "Neues über den alten Weltschmerz"1 endeavors to trace the earliest use of the word and finds an instance of it in Julian Schmidt's "Geschichte der Romantik," I847. He seems to have entirely overlooked Heine's use of the word in his discussion of Delaroche's painting "Oliver Cromwell before the body of Charles I." (I83I). ${ }^{3}$ The actual inventor of the compound was no doubt Jean Paul, who wrote (I8ro): "Diesen Weltschmerz kann er (Gott) sozusagen nur aushalten durch den Anblick der Seligkeit, die nachher vergütet."

But although Heine may have been the first to adapt the word to its present use, and although we have fallen into the habit of thinking of him as the chief representative of German Weltschmerz, it must be admitted that there is much less genuine Weltschmerz to be found in his poems than in those of either Hölderlin or Lenau. The reason for this has already been briefly indicated in the preceding chapter. Hölderlin's Weltschmerz is altogether the most naive of the three; Lenau's, while it still remains sincere, becomes self-conscious, while Heine has an unfailing antidote for profound feeling in his merciless self-irony. And yet his condition in life was such as would have wrung from the heart of almost any other poet notes of sincerest pathos.

In Lenau's case we noted circumstances which point to a

1 "Studien und Wandertage," Frauenfeld, Huber, 1884.

2 Vol. II, p. 265.

8 "Französische Maler. Gemälde-Ausstellung in Paris, 1831." Heines Sämmtliche Werke, mit Einleitung von E. Elster. Leipzig, Bibliogr. Inst., 1890. (Hereafter quoted as "Werke.") Vol. IV, p. 6r.

4 "Selina, oder über die Unsterblichkeit," II, p. 132. 
direct transmission from parent to child of a predisposition to melancholia. In Heine's, on the other hand, the question of heredity has apparently only an indirect bearing upon his Weltschmerz. To what extent was his long and terrible disease of hereditary origin, and in what measure may we ascribe his Weltschmerz to the sufferings which that disease caused him? The first of these questions has been answered as conclusively as seems possible on the basis of all available data, by a doctor of medicine, S. Rahmer, in what is at this time the most recent and most authoritative study that has been published on the subject. ${ }^{1}$ Stage by stage he follows the development of the disease, from its earliest indications in the poet's incessant nervous headaches, which he ascribes to neurasthenic causes. He attempts to quote all the passages in Heine's letters which throw light upon his physical condition, and points out that in the second stage of the disease the first symptoms of paralysis made their appearance as early as 1832 , and not in 1837 as the biographers have stated. To this was added in I837 an acute affection of the eyes, which continued to recur from this time on. In addition to the pathological process which led to a complete paralysis of almost the whole body, Rahmer notes other symptoms first mentioned in 1846 , which he describes as "bulbär" in their origin, such as difficulty in controlling the muscles of speech, difficulty in chewing and swallowing, the enfeebling of the muscles of the lips, disturbances in the functions of the glottis and larynx, together with abnormal secretion of saliva. He discredits altogether the diagnosis of Heine's disease as consumption of the spinal marrow, to which Klein-Hattingen in his recent book on Hölderlin, Lenau and Heine ${ }^{2}$ still adheres, dismisses as scientifically untenable the popular idea that the poet's physical dissolution was the result of his sensual excesses, finally diagnoses the case as "die spinale Form der progressiven Muskelatrophie"3 and maintains that it was either directly inherited, or at least developed on

\footnotetext{
1 "Heinrich Heines Krankheit und Leidensgeschichte." Eine kritische Studie, von S. Rahmer, Dr. Med., Berlin, rgor.

2 "Das Liebesleben Hölderlin's, Lenaus, Heines." Berlin, г90г.

${ }^{3}$ Rahmer, op. cit. p. 45 .
} 
the basis of an inherited disposition. ${ }^{1}$ He finds further evidence in support of the latter theory in the fact that the first symptoms of the disease made their appearance in early youth, not many years after puberty, and concludes that, in spite of scant information as to Heine's ancestors, we are safe in assuming a hereditary taint on the father's side.

The poet himself evidently would have us believe as much, for in his Reisebilder he says: "Wie ein Wurm nagte das Elend in meinem Herzen und nagte,-ich habe dieses Elend mit mir zur Welt gebracht. Es lag schon mit mir in der Wiege, und wenn meine Mutter mich wiegte, so wiegte sie es mit, und wenn sie mich in den Schlaf sang, so schlief es mit mir ein, und es erwachte, sobald ich wieder die Augen aufschlug. Als ich grösser wurde, wuchs auch das Elend, und wurde endlich ganz gross und zersprengte mein. ... Wir wollen von andern Dingen sprechen. ..."2

And yet Heine's disposition was not naturally inclined to hypochondria. In his earlier letters, especially to his intimate friends, there is often more than cheerfulness, sometimes a decided buoyancy if not exuberance of spirits. A typical instance we find in a letter to Moser ( I824): "Ich hoffe Dich wohl nächstes Frühjahr wiederzusehen und $z \mathfrak{u}$ umarmen und zu necken und vergnügt zu sein."3 Only here and there, but very rarely, does he acknowledge any influence of his physical condition upon his mental labors. To Immermann he writes (I823): "Mein Unwohlsein mag meinen letzten Dichtungen auch etwas Krankhaftes mitgeteilt haben." ${ }^{\prime}$ And to Merkel (1827): "Ach! ich bin heute sehr verdriesslich. Krank und unfähig, gesund aufzufassen." ${ }^{\circ}$ In the main, however, he makes a very brave appearance of cheerfulness, and especially of patience, which seems to grow with the hopelessness of his affliction. To his mother (185I): "Ich befinde mich wieder krankhaft gestimmt, etwas wohler wie früher, vielleicht viel wohler; aber grosse Nervenschmerzen habe ich noch immer,

${ }^{1}$ Rahmer, p. 46.

2 Werke, Vol. III, p. 194.

3 narpeles ed. Werke (2. Aufl.) VIII, p. 44I.

4 Ibid., p. 378.

Ibid., p. 520. 
und leider ziehen sich die Krämpfe jetzt öfter nach oben, was mir den Kopf zuweilen sehr ermüdet. So muss ich nun ruhig aushalten, was der liebe Gott über mich verhängt, und ich trage mein Schicksal mit Geduld. . . . Gottes Wille geschehe!"1 Again a few weeks later: "Ich habe mit diesem Leben abgeschlossen, und wenn ich so sicher wäre, dass ich im Himmel einst gut aufgenommen werde, so ertrüge ich geduldig meine Existenz.", Not only to his mother, whom for years he affectionately kept in ignorance of his deplorable condition, does he write thus, but also to Campe (1852): "Mein Körper leidet grosse Qual, aber meine Seele ist ruhig wie ein Spiegel und hat manchmal auch noch ihre schönen Sonnenaufgänge und Sonnenuntergänge."3 1854: "Gottlob, dass ich bei all meinem Leid sehr heiteren Gemütes bin, und die lustigsten Gedanken springen mir durchs Hirn." 4 Much of this sort of thing was no doubt nicely calculated for effect, and yet these and similar passages show that he was not inclined to magnify his physical afflictions either in his own eyes or in the eyes of others. Nor is he absolutely unreconciled to his fate: "Es ist mir nichts geglückt in dieser Welt, aber es hätte mir doch noch schlimmer gehen können."

In his poems, references to his physical sufferings are remarkably infrequent. We look in vain in the "Buch der Lieder," in the "Neue Gedichte," in fact in all his lyrics written before the "Romanzero," not only for any allusion to his illness, but even for any complaint against life which might have been directly occasioned by his physical condition. What is there then in these earlier poems that might fitly be called Weltschmerz? Very little, we shall find.

Their inspiration is to be found almost exclusively in Heine's love-affairs, decent and indecent. Now the pain of disappointed love is the motive and the theme of very many of Hölderlin's and Lenau's lyrics, poems which are heavy with Weltschmerz, while most of Heine's are not. To speak only

\footnotetext{
${ }^{1}$ Karpeles ed. Werke, IX, p. 37 I.

Ibid., p. 374 .

I Ibid., p. 459 ff.

Ibid., p. $5 \mathrm{I} 3$.

Ibid., p. 475 .
} 
of the poet's most important attachments, of his unrequited love for his cousin Amalie, and his unsuccessful wooing of her sister Therese,- - there can be no doubt that these unhappy loves brought years of pain and bitterness into his life, sorrow probably as genuine as any he ever experienced, and yet how little, comparatively, there is in his poetry to convince us of the fact. Nearly all these early lyrics are variations of this love-theme, and yet it is the exception rather than the rule when the poet maintains a sincere note long enough to engender sympathy and carry conviction. Such are his beautiful lyrics "Ich grolle nicht,"' "Du hast Diamanten und Perlen.",

Let us see how Lenau treats the same theme:

Die dunklen Wolken hingen

Herab so bang und schwer,

Wir beide traurig gingen

Im Garten hin und her.

So heiss und stumm, so trübe, Und sternlos war die Nacht,

So ganz wie unsre Liebe

$\mathrm{Zu}$ Thränen nur gemacht.

Und als ich musste scheiden

Und gute Nacht dir bot,

Wünscht' ich bekümmert beiden

Im Herzen uns den Tod.

We believe implicitly in the poet's almost inexpressible grief, and because we are convinced, we sympathize. And we feel too that the poet's sorrow is so overwhelming and has so filled his soul that it has entirely changed his views of life and of nature, or has at least contributed materially to such a change,-that it has assumed larger proportions and may rightly be called Weltschmerz. Compare with this the first and third stanzas of Heine's "Der arme Peter:"

Der Hans und die Grete tanzen herum,

Und jauchzen vor lauter Freude.

Der Peter steht so still und stumm,

1 Werke, Vol. I, p. 72, Nos. 18 and 19.

2 Werke, Vol. I, p. 123, No. 62.

${ }^{3}$ Lenaus Werke, Vol. I, p. 257 ff. 
Und ist so blass wie Kreide.

Der Peter spricht leise vor sich her

Und schauet betrübet auf beide :

"Ach! wenn ich nicht zu vernünftig wär', Ich thät' mir was zu leide."

It is scarcely necessary to cite further examples of this mannerism of Heine's, for so it early became, such as his "Erbsensuppe,"' "Ich wollte, er schösse mich tot,"3 "Doktor, sind Sie des Teufels ;" "Madame, ich liebe Sie!"' and many other glaring instances of the "Sturzbad," in order to show how the poet himself deliberately attempted, and usually with success, to destroy the traces of his grief. This process of self-irony, which plays such havoc with all sincere feeling and therefore with his Weltschmerz, becomes so fixed a habit that we are almost incapable, finally, of taking the poet seriously. $\mathrm{He}$ makes a significant confession in this regard in a letter to Moser (I823): "Aber es geht mir oft so, ich kann meine eigenen Schmerzen nicht erzählen, ohne dass die Sache komisch wird."' How thoroughly this mental attitude had become second nature with Heine, may be inferred from a statement which he makes to Friederike Roberts (1825): "Das Ungeheuerste, das Ensetzlichste, das Schaudervollste, wenn es nicht unpoetisch werden soll, kann man auch nur in dem buntscheckigen Gewande des Lächerlichen darstellen, gleichsam versöhnend-darum hat auch Shakespeare das Grässlichste im "Lear" durch den Narren sagen lassen, darum hat auch Goethe zu dem furchtbarsten Stoffe, zum "Faust," die Puppenspielform gewählt, darum hat auch der noch grössere Poet (der Urpoet, sagt Friederike), nämlich Unser-Herrgott, allen Schreckensszenen dieses Lebens eine gute Dosis Spasshaftigkeit beigemischt.",

\footnotetext{
1 Werke, Vol. I, p. 37.

2 Ibid., Vol. II, p. II.

${ }^{3}$ Ibid., Vol. I, p. 97.

4 Ibid., Vol. I, p. 177 .

s Ibid., Vol. I, p. 197.

${ }^{6}$ Karpeles ed. Werke, VIII, p. 408.

7 Ibid., p. 468.
} 
In not a few of his lyrics Heine gives us a truly Lenauesque nature-setting, as for instance in "Der scheidende Sommer:"

Das gelbe Laub erzittert,

Es fallen die Blätter herab;

Ach, alles, was hold und lieblich

Verwelkt und sinkt ins Grab. ${ }^{1}$

This is one of the comparatively few instances in Heine's lyrics in which he maintains a dignified seriousness throughout the entire poem. It is worth noting, too, because it touches a note as infrequent in Heine as it is persistent in Lenau-the fleeting nature of all things lovely and desirable. ${ }^{2}$ This is one of the characteristic differences between the two poets,Heine's eye is on the present and the future, much more than on the past; Lenau is ever mourning the happiness that is past and gone. Logically then, thoughts of and yearnings for death are much more frequent with Lenau than with Heine. ${ }^{3}$

Reverting to the point under consideration: even in those love-lyrics in which Heine does not wilfully destroy the first serious impression by the jingling of his harlequin's cap, as he himself styles it, ${ }^{4}$ he does not succeed,-with the few exceptions just referred to,-in convincing us very deeply of the reality of his feelings. They are either trivially or extravagantly stated. Sometimes this sense of triviality is caused by the poet's excessive fondness for all sorts of diminutive expressions, giving an artificial effect, an effect of "Tändelei" to his verses. For example:

$\mathrm{Du}$ siehst mich an wehmütiglich, Und schüttelst das blonde Köpfchen, Aus deinen Augen schleichen sich Die Perlenthränentröpfchen. ${ }^{5}$

Sometimes this effect is produced by a distinct though unin-

1 Karpeles ed. Werke, Vol. II, p. 3 I.

${ }^{2} \mathrm{~A}$ few other examples of this same coloring in Heine's lyrics are to be found in the "Neuer Frühling," Nos. 40, 4I and 43.

'Werke, Vol. II, p. 89, No. 55, "O Gott, wie hässlich bitter ist das Sterben!" etc.

"Engel: “Heine's Memoiren," p. r 33.

Werke, Vol. I, p. 87. 
tended anti-climax. Nowhere has Heine struck a more truly elegiac note than in the stanza:

Der Tod, das ist die kühle Nacht,

Das Leben ist der schwüle Tag.

Es dunkelt schon, mich schläfert,

Der Tag hat mich müde gemacht. ${ }^{1}$

There is the most profound Weltschmerz in that. But in the second stanza there is relatively little:

Ueber mein Bett erhebt sich ein Baum,

Drin singt die junge Nachtigall;

Sie singt von lauter Liebe,

Ich hör' es sogar im Traum.

Lenau's lyrics have shown that much Weltschmerz may grow out of unsatisfied love; Heine's demonstrate that mere lovesickness is not Weltschmerz. The fact is that Heine frequently destroys what would have been a certain impression of Weltschmerz by forcing upon us the immediate cause of his distemper,-it may be a real injury, or merely a passing annoyance. What a strange mixture of acrimonious, sarcastic protest and Weltschmerz elements we find in the poem "Ruhelechzend"' of which a few stanzas will serve to illustrate. Again he strikes a full minor chord:

\footnotetext{
Las bluten deine Wunden, lass

Die Thränen fliessen unaufhaltsam;

Geheime Wollust schwelgt im Schmerz,

Und Weinen ist ein süsser Balsam.
}

This in practice rather than in theory is what we observe in Lenau,-his melancholy satisfaction in nursing his grief,and we have promise of a poem of genuine Weltschmerz. Even through the second and third stanzas this feeling is not destroyed, although the terms "Schelm" and "Tölpel" gently arouse our suspicion :

Des Tages Lärm verhallt, es steigt

Die Nacht herab mit langen Flöhren.

In ihrem Schosse wird kein Schelm,

Kein Tölpel deine Ruhe stören.

${ }^{1}$ Werke, Vol. I, p. 134 .

2 Ibid., Vol. II, p. Iо2. 
But the very next stanza brings the transition from the sublime to the ridiculous:

Hier bist du sicher vor Musik,

Vor des Pianofortes Folter,

Und vor der grossen Oper Pracht

Und schrecklichem Bravourgepolter.

O Grab, du bist das Paradies

Für pöbelscheue, zarte Ohren-

Der Tod ist gut, doch besser wär's,

Die Mutter hätt' uns nie geboren.

It is scarcely necessary to point out that the specific cause which the poet confides to us of his "wounds, tears and pains" is ridiculously unimportant as compared with the conclusion which he draws in the last two lines.

Evidently then, he does not wish us to take him seriously, nor could we, if he did. Thus in their very attitude toward the ills and vexations of life, there appears a most essential difference between Lenau and Heine. Auerbach aptly remarks: "Spott und Satire verkleinern, Zorn und Hass vergrössern das Object." 1 And Lenau knew no satire; where Heine scoffed and ridiculed, he hated and scorned, with a hatred that only contributed to his own undoing. With Heine the satire's the thing, whether of himself or of others, and to this he willingly sacrifices the lofty sentiments of which he is capable. Indeed he frequently introduces these for no other purpose than to make the laugh or grimace all the more striking. And with reference to his love affair with Amalie, while the question as to the reality and depth of his feelings may be left entirely out of discussion, this much may be safely asserted, that in comparatively few poems do those feelings find expression in the form of Weltschmerz. Now there is something essentially vague about Weltschmerz; it is an atmosphere, a "Stimmung" more or less indefinable, rather than the statement in lyric form of certain definite grievances with their particular and definite causes. And that is exactly what we find in Lenau, even in his love-songs. His love-sorrow is blended with his many other heart-aches, with his disappointments and

1 "Nicolaus Lenau. Erinnerung und Betrachtung." Wien, 1876. 
regrets, with his yearning for death. He sings of his pain rather than of its immediate causes, and the result is an atmosphere of Weltschmerz.

Turning to Heine's later poems, especially to the "Romanzero," we find that atmosphere much more perceptible. But even here the poet is for the most part specific, and his method concrete. So for instance in "Der Dichter Firdusi"' in which he tells a story to illustrate his belief that merit is appreciated and rewarded only after the death of the one who should have reaped the reward. So also in "Weltlauf,"" the first stanza of which suggests a poetic rendering of Matth. I3:I2, "For whosoever hath, to him shall be given and he shall have more abundance; but whosoever hath not, from him shall be taken away even that he hath,"- - to which the poet adds a stanza of caustic ironical comment:

Wenn du aber gar nichts hast,

Ach, so lasse dich begraben-

Denn ein Recht zum Leben, Lump,

Haben nur, die etwas haben.

And again, the poem "Lumpentum"s presents an ironical eulogy of flattery. His failure to realize the hopes of his youth is made the subject of "Verlorne Wünsche" which maintains throughout a strain of seriousness quite unusual for Heine, and concludes :

Goldne Wünsche! Seifenblasen!

Sie zerrinnen wie mein Leben-

Ach ich liege jetzt am Boden,

Kann mich nimmermehr erheben.

Und Ade! sie sind zerronnen,

Goldne Wünsche, süsses Hoffen!

Ach, zu tötlich war der Faustschlag,

Der mich just ins Herz getroffen.

A number of these lyrics from the Romanzero show very strikingly Heine's objective treatment of his poems of complaint. Such selections as "Sie erlischt,", in which he com-

${ }^{1}$ Werke, Vol. I, p. 367 f.

2 Ibid., Vol. I, p. 415.

Ibid., Vol. I, p. 48.

4 Ibid., Vol. I, p. 42 f.

B Ibid., Vol. I, p. 428 . 
pares his soul to the last flicker of a lamp in the darkened theater, or "Frau Sorge," care, represented as a nurse watching by his bedside, bring his objective method into marked contrast with Hölderlin's subjective Weltschmerz. The same may be said of his autobiography in miniature, "Rückschau,", which catalogues the poet's experiences, pleasant and adverse, with evident sincerity though of course with a liberal admixture of witty irony. Needless to say there is no real Weltschmerz discoverable in such a pot pourri as the following:

Die Glieder sind mir rheumatisch gelähmt,

Und meine Seele ist tief beschämt.

Ich ward getränkt mit Bitternissen,

Und grausam von den Wanzen gebissen, etc.

It would scarcely be profitable to attempt to estimate the causes and development of this self-irony, which plays so important a part in Heine's poetry. Its possibility lay no doubt in his native mother-wit, with its genial perception of the incongruous, combined, it must be admitted, with a relatively low order of self-respect. Its first incentive he may have found in his unrequited love for Amalie. Had it been like that of Hölderlin for Diotima, or Lenau for Sophie, reciprocated though unsatisfied, we could not easily imagine the ironical tone which pervades most of his love-songs. And so he uses it as a veil for his chagrin, preferring to laugh and have the world laugh with him, rather than to weep alone. But the incident in Heine's life which probably more than any other experience fostered this habit of making himself the butt of his witty irony was his outward renunciation of Judaism. Little need be said concerning this, since the details are so well known. He himself confesses that the step was taken from the lowest motives, for which he justly hated and despised himself. To Moser he writes (I825): "Ich weiss nicht, was ich sagen soll, Cohen versichert mich, Gans predige das Christentum und suche die Kinder Israels zu be-

${ }^{1}$ Werke, Vol. I, p. 424.

${ }^{2}$ Ibid., Vol. I, p. 416 . 
kehren. Thut er dieses aus Ueberzeugung, so ist er ein Narr; thut er es aus Gleissnerei, so ist er ein Lump. Ich werde zwar nicht aufhören, Gans zu lieben; dennoch gestehe ich, weit lieber wär's mir gewesen, wenn ich statt obiger Nachricht erfahren hätte, Gans habe silberne Löffel gestohlen. . . . Es wäre mir sehr leid, wenn mein eigenes Getauftsein Dir in einem günstigen Lichte erscheinen könnte. Ich versichere Dich, wenn die Gesetze das Stehlen silberner Löffel erlaubt hätten, so würde ich mich nicht getauft haben."1 But in addition to the loss of self-respect came his disappointment and chagrin at the non-success of his move, since he realized that it was not even bringing him the material gain for which he had hoped. Instead, he felt himself an object of contempt among Christians and Jews alike. "Ich bin jetzt bei Christ und Jude verhasst. Ich bereue sehr, dass ich mich getauft hab'; ich sehe gar nicht ein, dass es mir seitdem besser gegangen sei; im Gegenteil, ich habe seitdem nichts als Unglück."' $\mathrm{He}$ is so unhappy in consequence of this step that he earnestly desires to leave Germany. "Es ist aber ganz bestimmt, dass es mich sehnlichst drängt, dem deutschen Vaterlande Valet zu sagen. Minder die Lust des Wanderns als die Qual persönlicher Verhältnisse (z. B. der nie abzuwaschende Jude) treibt mich von hinnen.",3

In his tragedy "Almansor," written during the years 1820 and I82I, ${ }^{4}$ his deep-rooted antipathy to Christianity finds strong expression through Almansor, although the countervailing arguments are eloquently stated by the heroine. Prophetic of the poet's own later experience is the representation of the hero, who is beguiled by his love for Zuleima into vowing allegiance to the Christian faith, only to find that the sacrifice has failed to win for him the object for which it was made. In the character of Almansor, more than anywhere else, Heine's "Liebesschmerz" and "Judenschmerz" have combined to produce in him an inner dissonance which expresses itself in lyric lines of real Weltschmerz:

${ }^{1}$ Karpeles ed. Werke, VIII, p. 473.

${ }^{2}$ Cf. Heine's letter to Moser, Jan. 9, 1826, in Karpeles' Autob. p. I91.

${ }^{3}$ Karpeles ed. Werke, VIII, p. 49 r.

${ }^{4}$ Cf. Werke, Einleitung, Vol. II, p. $24 \mathrm{I}$. 
Ich bin recht müd

Und krank, und kranker noch als krank, denn ach, Die allerschlimmste Krankheit ist das Leben;

Und heilen kann sie nur der Tod .....

But here too, as in "Ratcliff," such passages are exceptional. In the main these tragedies are nothing more than vehicles for the poet's stormy protest, much of it after the Storm and Stress pattern ; and mere protest, however acrimonious, cannot be called Weltschmerz.

Certain it is that during these early years numerous disappointments other than those of love contributed to produce in the poet a gloomy state of mind. A reflection of the unhappiness which he had experienced during his residence in Hamburg is found in many passages in his correspondence which express his repugnance for the city and its people. To Immanuel Wohlwill (1823): "Es freut mich, dass es Dir in den Armen der aimablen Hammonia zu behagen beginnt; mir ist diese Schöne zuwider. Mich täuscht nicht der goldgestickte Rock, ich weiss, sie trägt ein schmutziges Hemd auf dem gelben Leibe, und mit den schmelzenden Liebesseufzern 'Rindfleisch $^{3}$ Banko!' sinkt sie an die Brust des Meistbietenden. ... . Vielleicht thue ich aber der guten Stadt Hamburg unrecht; die Stimmung, die mich beherrschte, als ich dort einige Zeit lebte, war nicht dazu geeignet, mich zu einem unbefangenen Beurteiler zu machen; mein inneres Leben war brütendes Versinken in den düsteren, nur von phantastischen Lichtern durchblitzten Schacht der Traumwelt, mein äusseres Leben war toll, wüst, cynisch, abstossend ; mit einem Worte, ich machte es zum schneidenden Gegensatz meines inneren Lebens, damit mich dieses nicht durch sein Uebergewicht zerstöre." 3 To Moser (1823) : "Hamburg? sollte ich dort noch so viele Freuden finden können, als ich schon Schmerzen dort empfand? Dieses ist freilich unmöglich_", "Hamburg!!! mein Elysium und Tartarus zu gleicher Zeit! Ort, den ich detestiere und am meisten liebe, wo mich die abscheulichsten Gefühle martern und

1 Werke, Vol. II, p. 293.

2 Cf. Almansor's speech, Werke, Vol. II, p. 288 f.

${ }^{3}$ Karpeles ed. Werke, VIII, p. 363 .

Ibid., p. 384 . 
wo ich mich dennoch hinwünsche." ${ }^{1}$ Another letter to Moser is dated: "Verdammtes Hamburg, den 14. Dezember, 1825." The following year he writes, in a letter to Immermann: "Ich verliess Göttingen, suchte in Hamburg ein Unterkommen, fand aber nichts als Feinde, Verklatschung und Aerger."'3 And to Varnhagen von Ense (I828) : "Nach Hamburg werde ich nie in diesem Leben zurückkehren; es sind mir Dinge von der äussersten Bitterkeit dort passiert, sie wären auch nicht zu ertragen gewesen, ohne den Umstand, dass nur ich sie weiss." 4 To his mother's insistent pleading he replies (I833): "Aber ich will, wenn Du es durchaus verlangst, diesen Sommer auf acht Tage nach Hamburg kommen, nach dem schändlichen Neste, wo ich meinen Feinden den Triumph gönnen soll, mich wiederzusehen und mit Beleidigungen überhäufen zu können."’5

His several endeavors to establish himself on a firm material footing in life had failed,- - he had sought for a place in a Berlin high school, then entertained the idea of practising law in Hamburg, then aspired to a professorship in Munich, but without success. But more than by all these reverses, more even than by the circumstances and consequences of his Hebrew parentage, was the poet wrought up by the family strife over the payment of his pension, which followed upon the death of his uncle in December, I844, and which lasted for several years. From the very beginning he had had much intermittent annoyance through his dealings with his sporadically generous uncle Salomon Heine. As early as I823 Heine writes to Moser: "Auch weiss ich, dass mein Oheim, der sich hier so gemein zeigt, zu andern Zeiten dịe Generosität selbst ist; aber es ist doch in mir der Vorsatz aufgekommen, alles anzuwenden, um mich so bald als möglich von der Güte meines Oheims loszureissen. Jetzt habe ich ihn freilich noch nötig, und wie knickerig auch die Unterstützung ist, die er mir zufliessen lässt, so kann ich dieselbe nicht entbehren." ${ }^{\prime}$ And again in the same year: "Es ist fatal, dass bei mir der ganze Mensch durch das Budget

1 Karpeles ed. Werke, VIII, p. 39 .

2 Ibid., p. 472.

${ }^{8}$ Ibid., p. 503 .

${ }^{4}$ Ibid., p. 540.

- Ibid., IX, p. 25.

${ }^{6}$ Ibid., VIII, p. 392. 
regiert wird. Auf meine Grundsätze hat Geldmangel oder Ueberfluss nicht den mindesten Einfluss, aber desto mehr auf meine Handlungen. Ja, grosser Moser, der H. Heine ist sehr klein."' And when, after his uncle's demise, the heirs of the latter threatened to cut off the poet's pension, he writes to Campe $^{2}$ and to Detmold, ${ }^{3}$ in a frenzy of wrath and excitement, and shows what he is really capable of under pressure of circumstances. Perhaps it is only fair to suppose that his long years of suffering, both from his physical condition and from the unscrupulous attacks of his enemies, had had a corroding effect upon his moral sensibilities. In his request to Campe to act as mediator in the disagreeable affair he says : "Sie können alle Schuld des Missverständnisses auf mich schieben, die Grossmut der Familie hervorstreichen, kurz, mich sacrificiren." And all this to be submitted to the public in print! "Ich gestehe Ihnen heute offen, ich habe gar keine Eitelkeit in der Weise andrer Menschen, mir liegt am Ende gar nichts an der Meinung des Publikums; mir ist nur eins wichtig, die Befriedigung meines inneren Willens, die Selbstachtung meiner Seele." But how he was able to preserve his self-respect, and at the same time be willing to employ any and all means to attain his end, perhaps no one less unscrupulous than he could comprehend. He intimates that he has decided upon threats and public intimidation as being probably more effective than a servile attitude, which, he allows us to infer, he would be quite willing to take if advisable. "Das Beste muss hier die Presse thun zur Intimidation, und die ersten Kotwürfe auf Karl Heine und namentlich auf Adolf Halle werden schon wirken. Die Leute sind an Dreck nicht gewöhnt, während ich ganze Mistkarren vertragen kann, ja diese, wie auf Blumenbeeten, nur mein Gedeihen zeitigen."'4

It is quite evident that this long drawn out quarrel aroused all that was mean and vindictive, all that was immoral in the man, and that the nervous excitement thereby induced had a most baneful effect upon his entire nature, physical as well as

1 Karpeles ed. VIII, p. 396.

2 Ibid., IX, p. 308 ff.

8 Ibid., p. 3 I6.

- Letter to Detmold, Jan. 9, I845, Werke (Karpeles ed.), Vol. IX, p. 310. 
mental. In a number of poems he has given expression to his anger and has masterfully cursed his adversaries, for example, "Es gab den Dolch in deine Hand," "Sie küssten mich mit ihren falschen Lippen," ${ }^{2}$ and several following ones. But here, too, his fancy is altogether too busy with the suitable characterization of his enemies and the invention of adequate tortures for them, to leave room for even a suggestion of the Weltschmerz which we might expect to result from such painful emotions.

It is scarcely necessary to theorize as to what would have been the attitude and conduct of a sensitive Hölderlin or a proudspirited Lenau in a similar position. Lenau is too proud to protest, preferring to suffer. Heine is too vain to appear as a sufferer, so he meets adversity, not in a spirit of admirable courage, but in a spirit of bravado. In giving lyric utterance to his resentment, Heine is conscious that the world is looking on, and so he indulges, even in the expression of his Weltschmerz, in a vain ostentation which stands in marked contrast to Lenau's dignified pride. $\mathrm{He}$ is quite right when he says in a letter to his friend Moser: "Ich bin nicht gross genug, um Erniedrigung zu tragen.",

As an illustration of the vain display which he makes of his sadness, his poem "Der Traurige" may be quoted in part:
Allen thut es weh in Herzen,
Die den bleichen Knaben sehn,
Dem die Leiden, dem die Schmerzen
Auf's Gesicht geschrieben stehn. ${ }^{4}$

A similar impression is made by the concluding numbers of the Intermezzo, "Die alten, bösen Lieder." ${ }_{5}$ And here again the comparison,- -even if merely as to size,-of a coffin with the "Heidelberger Fass" is most incongruous, to say the least, and tends very effectually to destroy the serious sentiment which the poem, with less definite exaggerations, might have

\footnotetext{
${ }^{1}$ Werke, Vol. II, p. I04.

${ }^{2}$ Ibid., Vol. II, p. I0 5.

${ }^{3}$ Cf. Karpeles' Autob. p. I64.

4 Werke, Vol. I, p. 35.

s Ibid., Vol. I, p. 92.
} 
conveyed. Similarly overdone is his poetic preface to the "Rabbi" sent to his friend Moser :
Brich aus in lauten Klagen
$\mathrm{Du}$ düstres Märtyrerlied,
Das ich so lang getragen
Im flammenstillen Gemüt!
Es dringt in alle Ohren,
Und durch die Ohren ins Herz;
Ich habe gewaltig beschworen
Den tausendjährigen Schmerz.
Es weinen dir Grossen und Kleinen,
Sogar die kalten Herrn,
Die Frauen und Blumen weinen,
Es weinen am Himmel die Stern.

It is not necessary, even if it were to the point, to adduce further evidence of Heine's vanity as expressed in his prose writings, or in poems such as the much-quoted

Nennt man die besten Namen,

So wird auch der meine genannt. ${ }^{2}$

It cannot be denied that this element of vanity, of showiness, only serves to emphasize our impression of the unreality of much of Heine's Weltschmerz.

With the reference to this element of ostentation in Heine's Weltschmerz there is suggested at once the question of the Byronic pose, and of Byron's influence in general upon the German poet. On the general relationship between the two poets much has been written, ${ }^{3}$ so that we may confine ourselves here to the consideration of certain points of resemblance in their Weltschmerz.

Julian Schmidt names Byron as the constellation which ruled the heavens during the period from the Napoleonic wars to the "Völkerfrühling," I848, as the meteor upon which at that time the eyes of all Europe were fixed. Certainly the English poet could not have wished for a more auspicious introduction and

1 Werke, Vol. II, p. 164 .

2 Ibid., Vol. I, p. Io2.

${ }^{3}$ One of the most exhaustive monographs on the subject is that of Felix Melchior (Cf. bibliography, infra p. 90), to whom I am indebted for several of the parallels suggested. 
endorsation in Germany, if he had needed such, than that which was given him by Goethe himself, whose subsequent tribute in his Euphorion in the second part of "Faust" is one of Byron's most splendid memorials. The enthusiasm which Lord Byron aroused in Germany is attested by Goethe: "Im Jahre I8I6, also einige Jahre nach dem Erscheinen des ersten Gesanges des 'Childe Harold,' trat englische Poesie und Literatur vor allen andern in den Vordergrund. Lord Byrons Gedichte, je mehr man sich mit den Eigenheiten dieses ausserordentlichen Geistes bekannt machte, gewannen immer grössere Teilnahme, so dass Männer und Frauen, Mägdlein und Junggesellen fast aller Deutschheit und Nationalität zu vergessen schienen." 1

It is important to note that this first period of unrestrained Byron enthusiasm coincides with the formative and impressionable years of Heine's youth. In his first book of poems, published in $\mathrm{I} 82 \mathrm{I}$, he included translations from Byron, in reviewing which Immermann pointed out ${ }^{2}$ that while Heine's poems showed a superficial resemblance to those of Byron, the temperament of the former was far removed from the sinister scorn of the English lord, that it was in fact much more cheerful and enamored of life. ${ }^{3}$ There is plenty of evidence, however, to show that it was exceedingly gratifying to the young Heine to have his name associated with that of Byron; and although he had no enthusiasm for Byron's philhellenism, he was pleased to write, June 25, I824, on hearing of the Englishman's death: "Der Todesfall Byrons hat mich übrigens sehr bewegt. Es war der einzige Mensch, mit dem ich mich verwandt fühlte, und wir mögen uns wohl in manchen Dingen geglichen haben; scherze nur darüber, soviel Du willst. Ich las ihn selten seit einigen Jahren; man geht lieber um mit Menschen, deren Charakter von dem unsrigen verschieden ist. Ich bin aber mit Byron immer behaglich umgegangen, wie mit einem völlig gleichen Spiesskameraden. Mit Shakespeare kann ich gar nicht behaglich umgehen, ich

\footnotetext{
${ }^{1}$ Weimar Ausg. I Abt. Bd. 36, p. 128.

${ }^{2}$ In the Rheinisch-zvestfälischer Anzeiger, May 31, 1822, No. 23.

${ }^{3}$ Cf. Strodtmann, "H. Heines Leben und Werke," 3. ed., Hamburg, 1884. Vol. I, p. 200 .
} 
fühle nur zu sehr, dass ich nicht seinesgleichen bin, er ist der allgewaltige Minister, und ich bin ein blosser Hofrat, und es ist mir, als ob er mich jeden Augenblick absetzen könnte."1 Significant is the allusion in this same letter to a proposition which the writer seems to have made to his friend in a previous one: "... ich darf Dir Dein Versprechen in Hinsicht des 'Morgenblattes' durchaus nicht erlassen. Robert besorgt gern den Aufsatz. Byron ist jetzt tot, und ein Wort über ihn ist jetzt passend. Vergiss es nicht; Du thust mir einen sehr grossen Gefallen." "2 We shall probably not be far astray in assuming that the "Gefallen" was to have been the advertising of Heine as the natural successor of Byron in European literature. Three months later he once more urges the request: "Auch fände ich es noch immer angemessen, ja jetzt mehr als je, dass Du Dich über Byron und Komp. vernehmen liessest.",3

But it was not long before Heine, with an increasing sense of literary independence, reinforced no doubt by the reaction of public opinion against Byron, and influenced also by his friend Immermann's judgment in particular, ${ }^{4}$ was no longer willing to be considered a disciple of the English master. Several unmistakable references betoken this change of heart, for example, the following from his "Nordsee" III (1826): "Wahrlich in diesem Augenblicke fühle ich sehr lebhaft, dass ich kein Nachbeter, oder, besser gesagt, Nachfrevler, Byrons bin, mein Blut ist nicht so spleenisch schwarz, meine Bitterkeit kömmt nur aus den Galläpfeln meiner Dinte, und wenn Gift in mir ist, so ist es doch nur Gegengift, Gegengift wider jene Schlangen, die im Schutte der alten Dome und Burgen so bedrohlich lauern." "5 Byron, instead of being regarded as "kindred spirit" and "cousin," is now characterized as a ruthless de-

1 Karpeles ed. Werke, VIII, p. 434.

2 Ibid., p. 433.

8 Ibid., p. 44 I.

"In discussing the first volume of Heine's "Reisebilder," Immermann had said: "Man hat Heinen beim Beginn seiner dichterischen Laufbahn mit Byron vergleichen wollen. Diese Vergleichung scheint nicht zu passen. Der Brite bringt mit ungeheuren Mitteln nur mässige poetische Effekte hervor, während Heine eine Anlage zeigt, sich künstlerisch zu begrenzen und den Stoff gänzlich in die Form zu absorbieren." (Jahrbiücher f. wissenschaftliche Kritik, 1827, No. 97, p. 767.)

' Werke, III, p. I I6. 
stroyer of venerable forms, injuring the most sacred flowers of life with his melodious poison, or as a mad harlequin who thrusts the steel into his heart, in order that he may teasingly bespatter ladies and gentlemen with the black spurting blood. In remarkable contrast with his former views, he now writes: "Von allen grossen Schriftstellern ist Byron just derjenige, dessen Lektüre mich am unleidigsten berührt."

Perhaps the most interesting passage in this connection, because so thoroughly characteristic of the Byronic pose in Heine, occurs in the "Bäder von Lucca": "Lieber Leser, gehörst du vielleicht $\mathrm{zu}$ jenen frommen Vögeln, die da einstimmen in das Lied von Byronischer Zerrissenheit, das mir schon seit zehn Jahren in allen Weisen vorgepfiffen und vorgezwitschert worden ... ? Ach, teurer Leser, wenn du über jene Zerrissenheit klagen willst, so beklage lieber, dass die Welt selbst mitten entzwei gerissen ist. Denn da das Herz des Dichters der Mittelpunkt der Welt ist, so musste es wohl in jetziger Zeit jämmerlich zerrissen werden. Wer von seinem Herzen rühmt, es sei ganz geblieben, der gesteht nur, dass er ein prosaisches, weitabgelegenes Winkelherz hat. Durch das meinige ging aber der grosse Weltriss, und eben deswegen weiss ich, dass die grossen Götter mich vor vielen andern hoch begnadigt und des Dichtermärtyrtums würdig geachtet haben." ${ }^{1}$ Here while vociferously disclaiming all kinship or sympathy with Byron, he pays him the flattering compliment of imitation. Probably nowhere in Byron could we find a more pompous display of egoism under the guise of Weltschmerz.

Byron's Weltschmerz, like Heine's, had its first provocation in a purely personal experience. "To a Lady" and "Remembrance"s both give expression in passionate terms to the poet's disappointed love for Mary Chaworth, the parallel in Heine's case being his infatuation for his cousin Amalie. The necessity for defending himself against a public opinion actively hos-

\footnotetext{
${ }^{1}$ Werke, Vol. III, p. 304.

2 Byron's Works, Coleridge ed., London and New York, 1898. Vol. I, p. I89 ff.

${ }^{8}$ Ibid., p. $21 \mathrm{r}$.
} 
tile to his earliest poems, ${ }^{1}$ largely diverted Byron from this first painful theme, so that from this time on until he left England, he is almost incessantly engaged in a bitter warfare against the injustice of critics and of society. To this second period Heine's development also shows a general resemblance. Thus far both poets exhibit a purely egoistic type of Weltschmerz. But with his separation from his wife in 1816 , and his final departure from England, that of Byron enters upon a third period and becomes cosmic. Ostracized by English society, his relations with it finally severed, he disdains to defend himself further against its criticism, and espouses the cause of unhappy humanity. No longer his own personal woes, but rather those of the nations of the earth are nearest his heart:

What are our woes and sufferance? . . .

............ Ye!

Whose agonies are evils of a day-

A world is at our feet as fragile as our clay. ${ }^{2}$

And in contemplating the ruins of the Palatine Hill:

Upon such a shrine

What are our petty griefs? Let me not number mine.

Here we have the essential difference between these two types of Weltschmerz. Heine does not, like Byron, make this transition from the personal to the universal stage. Instead of becoming cosmic in his Weltschmerz, he remains for ever egoistic.

Numerous quotations might he adduced from the writings of both poets, which would seem to indicate that Heine had borrowed many of his ideas and even some forms of expression from Byron. Except in the case of the most literal correspondence, this is generally a very unsafe deduction. Such passages as a rule prove nothing more than a similarity, possibly quite independent, in the trend of their pessimistic

${ }^{1}$ Cf. the poems "To a Knot of Ungenerous Critics," "English Bards and Scotch Reviewers," and others.

2 Coleridge ed., Vol. II, p. 388 f.

8 Ibid., p. 406. 
thought. Compare for example Byron's lines in the poem "And wilt thou weep when I am low ?"

Oh lady! blessèd be that tear-

It falls for one who cannot weep;

Such precious drops are doubly dear

To those whose eyes no tear may steep, ${ }^{1}$

with Heine's stanza :

Seit ich sie verloren hab',

Schafft' ich auch das Weinen ab;

Fast vor Weh das Herz mir bricht,

Aber weinen kann ich nicht. ${ }^{2}$

Or again, "Childe Harold," IV, I36:

From mighty wrongs to petty perfidy

Have I not seen what human things could do?

From the loud roar of foaming calumny

To the small whisper of the as paltry few-

And subtler venom of the reptile crew, ${ }^{3}$

with the first lines of Heine's ninth sonnet:

Ich möchte weinen, doch ich kann es nicht;

Ich möcht' mich rüstig in die Höhe heben,

Doch kann ich's nicht; am Boden muss ich kleben,

Umkrächzt, umzischt von eklem Wurmgezücht,"

a thought which in one of his letters (I823) he paraphrases thus: "Der Gedanke an Dich, liebe Schwester, muss mich zuweilen aufrecht halten, wenn die grosse Masse mit ihrem dummen Hass und ihrer ekelhaften Liebe mich niederdrückt."'

There can be no doubt that Heine for a time studied diligently to imitate this fashionable model, pose, irony and all. So diligently perhaps, that he himself was sometimes unable to distinglish between imitation and reality. So at least it would appear from No. 44 of "Die Heimkehr :"

Ach Gott! im Scherz und unbewusst

Sprach ich, was ich gefühlet:

Ich hab mit dem Tod in der eignen Brust

Den sterbenden Fechter gespielet. ${ }^{\circ}$

${ }^{1}$ Coleridge ed., Vol. I, p. 266 f.

${ }^{2}$ Werke, Vol. I, p. 78.

${ }^{3}$ Coleridge ed., Vol. II, p. 429.

${ }^{4}$ Werke, Vol. I, p. 6 I.

${ }^{5}$ Karpeles ed. Werke, VIII, p. 4 II.

${ }^{6}$ Werke, I, p. II 7 . 
In summing up our impressions of the two poets we shall scarcely escape the feeling that while Byron is pleased to display his troubles and his heart-aches before the curious gaze of the world, they are at least in the main real troubles and sincere heart-aches, whereas Heine, on the other hand, does a large business in Weltschmerz on a very small capital.

Nor is Heine the man more convincing as to his sincerity than Heine the poet. No more striking instance of this fact could perhaps be found than his letter to Laube on hearing the news of Immermann's death. ${ }^{1}$ "Gestern Abend erfuhr ich durch das Journal des Debats ganz zufällig den Tod von Immermann. Ich habe die ganze Nacht durch geweint. Welch ein Unglück! ... Welch einen grossen Dichter haben wir Deutschen verloren, ohne ihn jemals recht gekannt zu haben! Wir, ich meine Deutschland, die alte Rabenmutter! Und nicht nur ein grosser Dichter war er, sondern auch brav und ehrlich, und deshalb liebte ich ihn. Ich liege ganz darnieder vor Kummer." But scarcely has he turned the page with a short intervening paragraph, when he continues: "Ich bin, sonderbar genug, sehr guter Laune," and concludes the letter with some small talk. Now if he was sincere, as we may assume he was, in the asseveration of his grief at the death of his friend, then either that grief must have been anything but profound, or we have the clearest sort of evidence of the poet's incapacity for serious feeling of more than momentary duration. It is safe to assert that Heine never set himself a high artistic task, and remained true to his purpose until the task was accomplished. In other words, Heine betrays a lack of will-energy along artistic lines, which in the case of Hölderlin and Lenau was more evident in their attitude toward the practical things of life.

But the fact that Heine never created a monumental literary work of enduring worth is not attributable solely to a fickleness of artistic purpose or lack of will-energy. We find its explanation rather in the poet's own statement: "Die Poesie ist am Ende doch nur eine schöne Nebensache."2 and to

1 Werke, Karpeles ed. Vol. IX, p. $162 \mathrm{f}$.

${ }^{2}$ Letter to Immermann, Werke (Karpeles ed.), Vol. VIII, p. 354.

6 
this principle, consciously or unconsciously, Heine steadily adhered. Certain it is that he took a much lower view of his art than did Hölderlin or Lenau. Hence we find him ever ready to degrade his muse by making it the vehicle for immoral thoughts and abominable calumnies. ${ }^{1}$

The question of Heine's patriotism has always been a muchdebated one, and must doubtless remain so. But whatever opinion we may hold in regard to his real attitude and feelings toward the land of his birth, this we shall have to admit, that there are exceedingly few traces of Weltschmerz arising from this source. Genuine feeling is expressed in the two-stanza poem "Ich hatte einst ein schönes Vaterland"' and also in "Lebensfahrt,"3 although this latter poem illustrates a characteristic of so many of his writings, namely that he himself is their central figure. It is the sublime egoism which characterizes Heine and all his works. No wonder, then, that one of his few "Freiheitslieder" refers to his own personal liberty. ${ }^{4}$ For the failings of his countrymen he is ever ready with scathing satire, ${ }^{5}$ he grieves over his separation from them only when he thinks of his mother $;^{6}$ and in regard to the future of Germany he is for the most part sceptical. ${ }^{7}$ In a word, Heine's lyric utterances in regard to his fatherland are of so mixed a character, that altogether aside from the question of the sincerity of his feeling toward the land of his birth, certainly none but the blindest partisan would be able to discover more than a negligible quantity of Weltschmerz directly attributable to this influence.

Heine's conscience is at best a doubtful quantity. Where Byron with a sincere sense and acknowledgment of his guilt writes :

${ }^{1}$ Cf. his vulgar prognostication of Germany's future, Kaput XXVI of the "Wintermärchen," Werke, Vol. II, p. 488 ff.

${ }^{2}$ Werke, Vol. I, p. 263.

${ }^{3}$ Ibid., Vol. I, p. 308.

"Ibid., Vol. I, p. 30r, "Adam der erste."

5 Ibid., Vol. I, p. 316, "Zur Beruhigung."

'Ibid., Vol. I, p. 320, "Nachtgedanken."

'Cf. supra, note I. 


\begin{abstract}
"My injuries came down on those who loved meOn those whom I best loved: But my embrace was fatal."
\end{abstract}

Heine sees it in quite another light: "War ich doch selber jetzt das lebende Gesetz der Moral und der Quell alles Rechtes und aller Befugnis; die anrüchigsten Magdalenen wurden purifiziert durch die läuternde und sühnende Macht meiner Liebesflammen,"2 a moral aberration which he attributes to an imperfect interpretation of the difficult philosophy of Hegel. If further evidence were necessary to show the perversity of Heine's moral sense, the following paragraph from a letter to Varnhagen would suffice, in its way perhaps as remarkable a contribution to the theory of ethics as has ever been penned: "In Deutschland ist man noch nicht so weit, zu begreifen, dass ein Mann, der das Edelste durch Wort und That befördern will, sich oft einige kleine Lumpigkeiten, sei es aus Spass oder aus Vorteil, zu schulden kommen lassen darf, wenn er nur durch diese Lumpigkeiten (d. h. Handlungen, die im Grunde ignobel sind,) der grossen Idee seines Lebens nichts schadet, ja dass diese Lumpigkeiten oft sogar lobenswert sind, wenn sie uns in den Stand setzen, der grossen Idee unsres Lebens desto würdiger zu dienen."3 Scarcely less remarkable is the poet's confession to his friend Moser that he has a rubber soul: "Ich kann Dir das nicht oft genug wiederholen, damit $\mathrm{Du}$ mich nicht misst nach dem Massstabe Deiner eigenen grossen Seele. Die meinige ist Gummi elastic, zieht sich oft ins Unendliche und verschrumpft oft ins Winzige. Aber eine Seele habe ich doch. I am positive, I have a soul, so gut wie Sterne. Das genüge Dir. Liebe mich um der wunderlichen Sorte Gefühls willen, die sich bei mir ausspricht in Thorheit und Weisheit, in Güte und Schlechtigkeit. Liebe mich, weil es Dir nun mal so einfällt, nicht, weil Du mich der Liebe wert hältst. ... Ich hatte einen Polen zum Freund, für den ich mich bis zu Tod besoffen hätte, oder, besser gesagt, für den ich mich hätte totschlagen lassen, und für den ich mich noch totschlagen liesse, und der Kerl taugte für keinen Pfennig,

1 "Manfred," Coleridge ed., IV, p. Ior.

2 Werke VI, p. 48.

${ }^{8}$ Karpeles ed. Werke, VIII, p. 541 . 
und war venerisch, und hatte die schlechtesten Grundsätzeaber er hatte einen Kehllaut, mit welchem er auf so wunderliche Weise das Wort 'Was?' sprechen konnte, dass ich in diesem Augenblick weinen und lachen muss, wenn ich daran denke."1

Taking him all in all then, Heine is not a serious personality, a fact which we need to keep constantly in mind in judging almost any and every side of his nature.

As a matter of fact, Heine's Weltschmerz, like his whole personality, is of so complex and contradictory a nature, that it would be a hopeless undertaking to attempt to weigh each contributing factor and estimate exactly the amount of its influence. All the elements which have been briefly noted in the foregoing pages, and probably many minor ones which have not been mentioned, combined to produce in him that "Zerrissenheit" which finds such frequent expression in his writings. But it must be remembered that this "Zerrissenheit" does not always express itself as Weltschmerz. In Heine it often appears simply as pugnacity; and where wit, satire, self-irony or even base calumny succeeds in covering up all traces of the poet's pathos we are no longer justified on sentimental or sympathetic grounds in taking it for granted. In looking for pathos in Heine's verse we shall not have to look in vain, it is true, but we shall find much less than his popular reputation as a poet of Weltschmerz would lead us to expect; and we frequently gain the impression that his disposition and his personal experiences are after all largely the excuse for rather than the occasion of his Weltschmerz.

Plümacher maintains: "Der Weltschmerz ist entweder die absolute Passivität, und die Klage seine einzige Aeusserung, oder aber er verpufft seine Kräfte in rein subjectivistischen, eudämonischen Anstrengungen,"2-a characterization which certainly holds good in the case of Lenau and Hölderlin respectively. Hölderlin, although in a visionary, idealistic way, remains, even in his Weltschmerz, altruistic and constructive. Lenau is passive, while Heine is solely egoistic and destructive.

1 Karpeles ed. Werke, VIII, p. 399.

2 Plümacher: "Der Pessimismus." Heidelberg, I888, p. I03. 


\section{CHAPTER V}

\section{Bibliography}

\section{General}

Breitinger, H. Neues über den alten Weltschmerz. "Studien und Wandertage." Frauenfeld, Huber, I884, p. 246-62.

Caro, E. Le Pessimisme au I9. Siècle; Leopardi, Schopen-

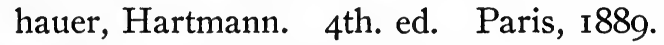

Deutsches Litteraturblatt, Halle a. S. 1879, Nr. I. Der Pessimismus in der Litteratur.

"Europa," I869, Nr. I6. Der Weltschmerz in der Poesie. von Golther, Ludwig. Der Moderne Pessimismus. Leipzig, 1878 .

Hartmann, Ed. Zur Begründung und Geschichte des Pessimismus. Leipzig, I892.

Heyse, Paul. Leopardi, der Dichter des Pessimismus. Deutsche Rundschau, Band I4, Art. I5.

Huber, Johannes. Der Pessimismus. München, 1876.

Lenzi, Annita. Il problema del dolore in alcune figure della letteratura. Roma, Bertero.

Lombroso, C. Der geniale Mensch. Hamburg, I900.

Nisbet. Pessimism and its Antidote. Macmillan's Magazine, London, Aug. I877.

Pfleiderer, E. Der Moderne Pessimismus. "Deutsche Zeitund Streitfragen," Berlin, I875.

Plümacher, O. Der Pessimismus in Vergangenheit und Gegenwart. 2d. ed. Heidelberg, i888.

Revue des deux Mondes, Dec. I877, p. 48I-5I4. L'Ecole pessimiste en Allemagne; son influence et son avenir.

Sully, James. Pessimism. A History and a Criticism. London, 1877 .

Westminster Review, Vol. I38, Oct. 1892. Pessimism and Poetry. 
Weygoldt, G. P. Kritik des philosophischen Pessimismus der neusten Zeit. Leiden, I875.

\section{Hölderlin}

Hölderlins Sämmtliche Werke, herausgegeben von C. T. Schwab. Stuttgart, I846.

Hölderlins gesammelte Dichtungen. Neu durchgesehene und vermehrte Ausgabe, mit biographischer Einleitung herausgegeben von B. Litzmann. Stuttgart, Cotta.

Arnold, R. F. Der deutsche Philhellenismus. Euphorion, I896, II Ergänzungsheft, p. 7 I ff.

Brandes, G. Die Hauptströmungen der Litteratur des I9. Jahrhunderts. Leipzig, I894. Vol. 2, p. 48-53.

Challemel-Lacour. La Poesie paienne en Allemagne au XIX. Siècle. Revue des deux Mondes, June, I867.

Haym, R. Die Romantische Schule. Berlin, I87o, p. 289-324 Jung, Alexander. Friedrich Hölderlin und seine Werke. Cotta, I848.

Klein-Hattingen, Oskar. Das Liebesleben Hölderlins, Lenaus, Heines. Berlin, Igor.

Köstlin, K. Dichtungen von Friedrich Hölderlin, mit biographischer Einleitung. Tübingen, I884.

Litzmann, Carl C. T. Friedrich Hölderlins Leben, in Briefen von und an Hölderlin. Berlin, I890.

(Reviewed by O. F. Walzel, Zeitschrift f. d. Alt. Anz. I7, p. 3I4-320.)

Müller, David. Friedrich Hölderlin, eine Studie. Preuss. Jahrbücher, I866, I7, p. 548-68.

Müller-Rastatt. Friedrich Hölderlins Leben und Dichten, Bremen, I894.

(Reviewed by Hermann Fischer, Anz. f. d. Alt. 22, p. 212-I8.) Rosenkranz, K. Aus Hegels Leben. I. Hegel und Hölderlin. Prutz, Literarhistor. Taschenbuch, I843, Bd. I, p. 89-200.

Scherer, Wilh. Vorträge und Aufsätze zur Geschichte des geistigen Lebens in Deutschland und Oesterreich. Berlin, I874. Hölderlin, p. 346-355.

Teuffel, W. S. Studien und Charakteristiken zur griechischen 
u. römischen sowie zur deutschen Litteraturgeschichte.

Leipzig, I87ı. Hölderlin, p. 473-502.

Waiblinger, Wilh. Friedrich Hölderlin's Leben, Dichtung und Wahnsinn. In Waiblinger's Werken, 3, p. 2r9-6r.

Wenzel, G. Hölderlin und Keats als geistesverwandte Dichter. Programm. Magdeburg, I896.

Wilbrandt, Adolf. Hölderlin. In "Geisteshelden. Eine Sammlung von Biographien," herausgegeben von Dr. Anton Bettelheim. Berlin, I896. 2 und 3 Band, p. I-46.

(Originally published as "Hölderlin, der Dichter des Pantheismus," in Riehls Historisches Taschenbuch, 5. Folge, I. Jahrgang. Leipzig, I871, p. 373-4I3.)

\section{Lenau}

Nicolaus Lenau's Sämmtliche Werke, herausgegeben von G. Emil Barthel. 2. Aufl. Leipzig (Ohne Jahr).

Lenau's Sämmtliche Werke, in 4 Bänden, Stuttgart, Cotta (Ohne Jahr).

Lenau's Werke, herausgegeben von Max Koch. Kürschners Nationallitt. I 54 und $I_{55}$.

Auerbach. Nicolaus Lenau. Erinnerung und Betrachtung. Wien, 1876.

Barewicz, Witold. Rezension von Zdziechowski, Der deutsche Byronismus. Euphorion, 1894, p. 417-18.

Berdrow, Otto. Frauenbilder aus der neueren deutschen Litteraturgeschichte. Stuttgart (ohne Jahr). Lenau's Mutter, p. 223-235; Sophie Löwenthal, p. 236-259; Marie Behrends, p. 260-80.

Castle, Ed. Nicolaus Lenau. Zur Jahrhundertfeier seiner Geburt. Leipzig, I902.

- Heimaterinnerungen bei Lenau. Grillparzer Jahrb. Wien, I900, p. 80-95.

- Nicolaus Lenaus Savonarola. Euphorion, 1896, Vol. 3, p. 74-92; 44I-64; I897, Vol. 4, p. 66-9I.

Ernst, Ad. Wilh. Litterarische Charakterbilder. Hamburg, 1895. Lenau, p. 253-74.

- Lenaus Frauengestalten. Stuttgart, I902.

Faggi, A. Lenau und Leopardi. Palermo, I898. 
Farinelli, A. Ueber Leopardis und Lenaus Pessimismus. Verhandlungen des 8. Allgem. d. Neuphilologentages, I898.

(Reviewed in Neuphil. Centralblatt, Sept. I898).

Fischer, Kuno. Der Philosoph des Pessimismus. Kleine Schriften, Heidelberg, I897.

Frankl, L. A. Zur Biographie Nicolaus Lenaus. 2. Aufl. Wien, Pest, Leipzig, Hartleben, 1885.

- Lenau und Sophie Löwenthal. Cotta, I8gr.

(Reviewed by Minor, Anz. f. d. Alt. I8, p. 276-29r.)

Friedrichs, Paul. Nicolaus Lenau. Nordd. Allg. Ztg. I902, Nr. 188.

Gesky, Theodor. Lenau als Naturdichter. Leipzig, I902.

Hohenhausen, F. Nicolaus Lenau und Emilie Reinbeck.

Westermanns Ill. Monatsh. Mai, I873.

Kerner, Theobald. Das Kernerhaus und seine Gäste. Deutsche Verlagsanstalt, I894.

Klein-Hattingen, Oscar. See under Hölderlin.

Marchand, Alfred. Les Poètes lyriques de l'Autriche. Paris, Fischbacher, I889.

Martensen, U. Aus meinem Leben. Berlin, I89I.

Mayer, Karl. Nicolaus Lenaus Briefe an einen Freund.

Stuttgart, 1853 .

Müller-Frauenstein. Von Heinrich von Kleist bis zur Gräfin

M. Ebner-Eschenbach. Hannover, I89i. Lenau, p. I23-33.

Röttinger, Heinrich. Lenaus Bertha. Ein Beitrag zur Lebensgeschichte des Dichters. Euphor. 1899, p. 752-61.

Sadger, J. Nicolaus Lenau. Ein pathologisches Lebensbild.

Neue Freie Presse, Nr. i i i 66-7. Sept. 25, 26, 1895.

(Reviewed by Castle, Euphor. I899, p. 792-95.)

Roustan, L. Lenau et son Temps, Paris, 1898.

(Reviewed by Castle, Euphor. I899, p. 785-97, in which review

he quotes at length the opinion of Dr. Med. Karl Weiler.)

Saly-Stern, J. La vie d'un Poète. Essai sur Lenau. Paris, 1902.

Scherr, J. Ein Dichter des Weltleids. Hammerschläge und Historien, Zürich, 1872. 
Schlossar, Dr. A. Nicolaus Lenau's Briefe an Emilie v. Reinbeck, nebst Aufzeichnungen. Stuttgart, I896.

Schurz, Anton X. Lenaus Leben, grossentheils aus des Dichters eignen Briefen. 2 vols. Cotta, 1855.

Sintenis, Franz. Nicolaus Lenau. Vortrag. 1892.

Von Klenze, Camillo. The Treatment of Nature in the Works of Lenau. Chicago Univ. Press, 1902.

Wechsler, Ed. Nicolaus Lenau. Eine litterarische Studie. Westermanns Ill. Monatsh. 68, p. 676-92.

Weisser, Paul. Lenau und Marie Behrends. Deutsche Rundschau, I889, p. $420 \mathrm{ff}$.

Witt, A. Lenau's Leben und Charakter. Marburg, I893.

\section{Heine}

Heinrich Heines Sämmtliche Werke. Hamburg, Hoffmann und Campe, 1876.

Heinrich Heines Gesammelte Werke. Kritische Gesammtausgabe, herausgegeben von Gustav Karpeles. Berlin, 1887.

Heinrich Heines Sämmtliche Werke. Kritisch durchgesehene und erläuterte Ausgabe, herausgegeben von Ernst Elster. Leipzig, Bibliogr. Inst. I89o.

Briefe von Heinrich Heine an seinen Freund Moses Moser. Leipzig, I862.

Arnold, Matthew. Essays in Criticism. 3d. ed. London, I875. Heinrich Heine, p. I8I-224.

Betz, Dr. Louis P. Heine in Frankreich. Eine litterarhistorische Untersuchung. Zürich, I895.

- Heinrich Heine und Alfred de Musset. Eine biographischlitterarische Parallele. Zürich, 1897.

(Reviewed by Walzel, Euphor. I898, p. 788 ff.)

Bölsche, Wilhelm. Heinrich Heine. Versuch einer ästhetischkritischen Analyse seiner Werke und seiner Weltanschauung. Leipzig, r888.

Ducros, Louis. Henri Heine et son Temps. Paris, 1886. Eliot, George. Essays and Leaves from a Note-book. London, 1884. Heine, p. 79-14I. 
Elster, Ernest. Zu Heines Biographie. Vierteljahrschrift für Litteraturgeschichte, I89I, Vol. 4, p. 465-512.

Engel, E. Heine's Memoiren und Gedichte. Prosa und Briefe. Hamburg, I884.

Gautier, Théophile. Portraits et Souvenirs Littéraires. Paris, I875. Henri Heine, p. I05-I28.

Goetze, R. Heines Buch der Lieder und sein Verhältnis zum Volkslied. Dissertation. Halle, I895.

Gottschall, Rudolf. Porträts und Studien. Leipzig, I87o. Heinrich Heine nach neuen Quellen, Bd. I. p. I85-264.

Houghton, Lord. Monographs, personal and social. London, 1873. The last days of Heinrich Heine, p. 293-339.

Hüffer, H. Aus dem Leben Heinrich Heines. Berlin, I878.

- H. Heine und Ernst C. A. Keller. Deutsche Rundschau, Nov. and Dec., I895.

Kalischer, Dr. Alfred C. Heinrich Heines Verhältnis zur Religion. Dresden, I89o.

Karpeles, Gustav. Heinrich Heine und das Judentum. Breslau, I868.

- Heinrich Heine und seine Zeitgenossen. Berlin, I888.

- Heine's Autobiographie, nach seinen Werken, Briefen und Gesprächen. Berlin, I888.

- H. Heine. Aus seinem Leben und aus seiner Zeit. Leipzig, I899.

Kaufmann, Max. Heine's Charakter und die Moderne Seele. Zürich, I902.

Keiter, H. H. Heine. Sein Leben, sein Charakter, seine Werke. Köln, I89ı.

Kohn-Abrest, F. Les Coulisses d'un Livre. A propos des Memoires de Henri Heine, Poète. Paris, I884.

Legras, Jules. Henri Heine, Poète. Paris, 1897.

(Reviewed by Walzel, Euphor. I898, Vol. 5, p. I49.)

Magnus, Lady. Jewish Portraits. London, r888. p. 45-8I.

(Originally in Macmillan's Magazine for 1883.)

Meiszner, Alfred. Heinrich Heine. Erinnerungen. Hamburg, 1856.

Melchior, Felix. Heinrich Heines Verhältnis zu Lord Byron. Litterarische Forschungen, XXVII Heft. Berlin, I903. 
Nietzki, M. Heine als Dichter und Mensch. Berlin, 1895.

(Reviewed by Fürst, Euphor. I898, Vol. 5, p. 342 f.)

Nollen. Heine und Wilhelm Müller. Mod. Lang. Notes, April, 1902.

Proelss, Robert. Heinrich Heine. Sein Lebensgang und seine Schriften. Stuttgart, I886.

Rahmer, S. Heinrich Heines Krankheit und Leidensgeschichte. Eine kritische Studie. Berlin, 1902.

Della Rocca. Skizzen über H. Heine. Wien, Pest, Leipzig, Hartleben, 1882.

Sandvoss, Franz. Was dünket Euch um Heine? Ein Bekenntnis. Leipzig, 1888.

Schmidt, Julian. Bilder aus dem geistigen Leben unsrer Zeit. Leipzig, 1870-71. Heine, Bd. 2, p. 283-350.

Schmidt-Weissenfels. Ueber Heinrich Heine. Berlin, I857. Selden, Camille. Les derniers Jours de H. Heine. Paris, I884.

Sharp, William. Life of Heinrich Heine. London, $\mathbf{1} 888$.

Sintenis, F. H. Heine; ein Vortrag. Dorpat, 1877.

Stigand. The Life, Works and Opinions of Heinrich Heine. London, 1875 .

Strodtmann, Adolf. Heinrich Heine's Wirken und Streben, Dargestellt an seinen Werken. Hamburg, 1857.

- Immortellen Heinrich Heine's. Berlin, I87r.

- H. Heine's Leben und Werke. III Aufl. Berlin, I884.

Stylo, A. Heine und die Romantik. Programm. Krakau, 1900.

Weill, Alexandre: Souvenirs Intimes de Henri Heine. Paris, I883. 
COLUMBIA UNIVERSITY GERMANIC STUDIES

Vol. II. No. III.

\section{EDWARD YOUNG IN GERMANY}

HISTORICAL SURVEYS

INFLUENCE UPON GERMAN LITERATURE

BIBLIOGRAPHY

BY

JOHN LOUIS KIND, Ph.D.

SOMETIME CARL SCHURZ FELLOW IN GERMAN, COLUMBIA UNIVERSITY

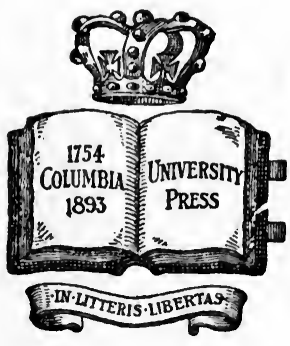

New Hark

THE COLUMBIA UNIVERSITY PRESS

THE MACMILLAN COMPANY, AgENTS

LONDON: MACMILLAN \& CO:, LTD.

I 906

All rights reserved 


\section{COLUMBIA UNIVERSITY GERMANIC STUDIES}

Edited by William H. Carpenter and Calvin Thomas

$$
\text { Vol. I }
$$

No. I. SCANDINAVIAN INFLUENCE ON SOUTHERN LOWLAND SCOTCH. A Contribution to the Study of the Linguistic Relations of English and Scandinavian. By George Tobias Flom, Ph.D. 8vo, paper, pp. $x v+82$. Price, $\$ 1.00$ net.

No. 2. OSSIAN IN GERMANY. Bibliography, General Survey, Ossian's Influence on Klopstock and the Bards. By Rudolf Tомво, JR., Ph.D. 8vo, paper, pp. iv + 157. Price, $\$ 1.00$ net.

No. 3. THE INFLUENCE OF OLD NORSE LITERATURE UPON ENGLISH LITERATURE. By Conrad H jalmar Nordby. 8vo, paper, pp. xi +78 . Price, \$1.00 net.

No. 4. THE INFLUENCE OF INDIA AND PERSIA ON THE POETRY OF GERMANY. By ARthur F. J. Remy, Ph.D. 8vo, paper, pp. xi $+8 \mathrm{r}$. Price, $\$ I .00$ net.

\section{Vol. II}

No. I. LAURENCE STERNE IN GERMANY. A Contribution to the Study of the Literary Relations of England and Germany in the Eighteenth Century. By Harvey Waterman Thayer, Ph.D. 8vo, paper, pp. $v+198$. Price, $\$ 1.00$ net.

No. 2. TYPES OF WELTSCHMERZ IN GERMAN POETRY. By Wilhelm Alfred Braun, Ph.D. 8vo, paper, pp. v +91 . Price, $\$ \mathrm{I} .00$ net. 
EDWARD YOUNG IN GERMANY 
The 1 ixto. 
VoL. II. No. III.

\title{
EDWARD YOUNG IN GERMANY
}

\author{
HISTORICAL SURVEYS \\ INFLUENCE UPON GERMAN LITERATURE \\ BIBLIOGRAPHY
}

BY

JOHN LOUIS KIND, Ph.D.

SOMETIME CARL SCHURZ FELLOW IN GERMAN, COLUMBIA UNIVERSITY

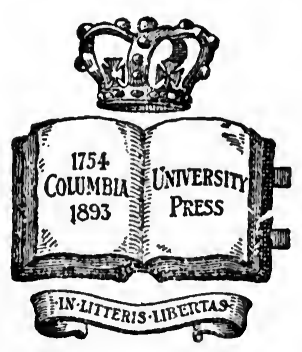

Newo Wark

THE COLUMBIA UNIVERSITY PRESS

THE MACMILLAN COMPANY, AGENTS

LONDON: MACMILLAN \& CO., LTD.

$$
1906
$$

All rights reserved 
COPYRIGHT, 1906,

By THE MACMILLAN COMPANY.

Set up and electrotyped. Published July, rgo6.

J. s. Cushing \& Co. - Berwick \& Smith Co. Norwood, Mass., U.S.A. 


\section{NOTE}

THE author of the present monograph has undertaken to record, more fully than has hitherto been attempted, the history of German interest in the works of Edward Young, and to trace in detail the influence which they have had upon German literature That such an influence has been exerted, particularly by the "Night Thoughts" and the "Conjectures on Original Composition," is a matter that has long been generally recognized, and a considerable literature has arisen upon the subject in its various phases. No such systematic treatment, however, as this, in which the whole matter is historically considered, has thus far been made. The writer in carrying out his plan has most carefully reëxamined the case in all its bearings, and has made, in this way, a contribution of undoubted reality and value to our knowledge of certain aspects of the literature of Germany in an important period of its history.

\section{WILLIAM H. CARPENTER.}

Columbia University, May 6, 1906. 

TO

THE MEMORY

OF

CARL SCHURZ

THIS WORK

IS MOST RESPECTFULLY

DEDICATED 



\section{PREFACE}

THE purpose of this investigation is to record as completely as possible the history of German interest in Young's works, and of the influence they exerted upon German literature, from the time of their first introduction to the present day.

The fact that the "Night Thoughts" exerted an extensive and powerful influence upon German poetry, likewise the fact that the German Geniekult, or literary glorification of "original genius," was greatly promoted and accelerated by the treatise "Conjectures on Original Composition," has long been recognized. Much has also been written upon the subject, in general and in detail. There seemed, nevertheless, to be room for further investigation, and especially for a treatment historically arranged and developed.

A word as to the arrangement and treatment of the various chapters. The "Conjectures" are discussed first, altho written many years after the "Night Thoughts," because the subjectmatter is newer and the results consequently more important.

For the survey of literary criticism in England prior to the "Conjectures" Thomas's excellent life of Young ${ }^{1}$ was most helpful, as thruout the dissertation, for its correct and extensive data on Young's life and works. Altho the Shakespeare Jahrbuch of 1903 contains a résumé and reprint of the "Conjectures," it dd not seem superfluous to give another synopsis of this essay, which is perhaps not too well known even to scholars. Chapter I having shown the position occupied by the "Conjectures" in England, Chapter II reviews succinctly literary criticism in Germany prior to the introduction of the "Conjectures," and then traces their influence historically as far as possible. All matter pertaining to the translations is treated together, altho necessarily breaking the chronological 1 " Le Poète Edward Young (1683-1765): Étude sur sa Vie et ses CEuvres par W. Thomas." Paris, I90I. 
order to some extent. Then follows in chronological order the discussion of the Litteraturbriefe, the Schleswigsche Litteraturbriefe and other writings of Gerstenberg, then the "Hamburgische Dramaturgie," which strictly should have been preceded by Herder's "Fragmente." However, the latter are best included under Herder's activity as a whole. Hamann and Herder, as the protagonists of the Geniekult, form the climax of the investigation. In Hamann the discussion is confined quite closely to direct influence of Young; whereas, in the case of Herder, a broader treatment seemed necessary, - one extending beyond Young's immediate influence and including Herder's general position in literary matters.

Chapter III, the survey of the "Night Thoughts" in Germany, deals historically with the introduction of Young's poem into Germany, the gradual increase and culmination of its popularity, the ensuing decline of its influence, the defection from its spirit, and the causes that led to this result. The second part of this chapter, treating of the influence of the "Night Thoughts" upon German writers, needs perhaps some apology. It was found, after thoro investigation, that Barnstorff's dissertation ${ }^{1}$ had virtually exhausted the subject of verbal correspondences in the influence of the "Night Thoughts" upon German writers. In some instances I have added material along the lines pursued by Barnstorff, but my aim on the whole has been to show how much the various writers concerned themselves with the "Night Thoughts," so far as one can judge from their letters and works, without going into the citation of line-forline parallels, to repeat which, after Barnstorff, would be futile. In arranging these writers I have followed Goedeke's "Grundriss" as closely as possible. The Swiss are treated first here as in the history of the movement, and followed by Gottsched, because he was the great opponent of Bodmer. The group of the Bremer Beiträge are, of course, the most important, and Ebert as the chief translator of Young has a right to head the list. Their associates and friends are also placed in this group, as well as others who belong to no special school. Klopstock

1 "Youngs Nachtgedanken und ihr Einfluss auf die deutsche Litteratur von Johannes Barnstorff. Mit einem Vorwort von Franz Muncker." Bamberg, 1895. 
was likewise an associate, but since he was the center about which the league of Göttingen writers, the Göttinger Dichterbund, revolved, he has been placed at the head of that school, forming in this arrangement, as in life, a connecting link between the Bremer Beiträger and the Göttinger Dichterbund. Crugot, Zimmermann, and Lavater were best grouped as philosophical writers, and the "Other Writers" need no further comment, except the fact that they are as nearly as possible arranged chronologically.

All of the classical writers, except Klopstock, were inclined to oppose Young's influence rather than to further it, and so they are placed first among the writers who led the reaction against the "Night Thoughts."

The minor works, except the "Revenge," exerted no considerable influence, but an account of the interest taken in them by the Germans may not be amiss. The arrangement here, too, follows no special system, but in general is based upon the importance attached to the works in Germany.

To Professor Calvin Thomas especially is due my warmest gratitude for the interest he has taken in this thesis, and the constant inspiration that he has given me during its progress. It is a pleasure also to tender my most grateful thanks to Professor William $\mathrm{H}$. Carpenter of Columbia University, and Professor Laurence Fossler of the University of Nebraska, for their stimulating and never failing assistance in my graduate work. I shall ever consider it a rare privilege to have been able to pursue the major part of my graduate studies under these three scholars.

New York, May I, I9o6. 



\section{CONTENTS}

\section{CHAPTER I}

The "Conjectures on Original Composition"

I. Young's Relation to Earlier English Writers of the Eigh-

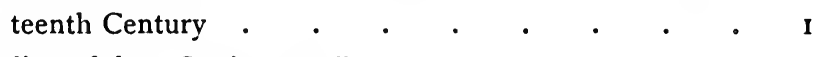

2. Outline of the "Conjectures" . . . . . . . 2

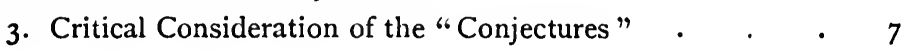

\section{CHAPTER II}

The "Conjectures" in Germany

I. General Survey of German Thought on Original Composi-

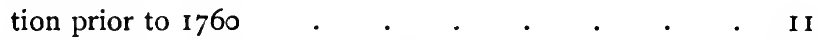

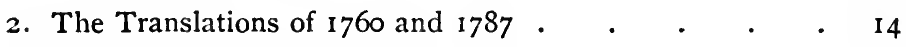

3. The Litteraturbriefe and the Idea of Originality . . $\quad$ I9

4. Heinrich Wilhelm von Gerstenberg and the Schleswigsche

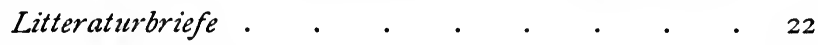

5. The Idea of Originality in the "Hamburgische Dramaturgie" 26

6. Johann Georg Hamann . . . . . . 28

7. Johann Gottfried Herder . . . . . . . 40

8. Conclusion . $\quad . \quad$. $\quad . \quad$. $\quad . \quad$. 57

\section{CHAPTER III}

The "Night Thoughts" in Germany

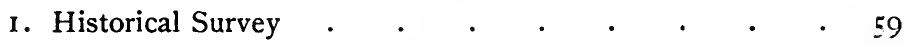

2. Influence upon German Writers • • • • $\quad 75$

\section{CHAPTER IV}

Other Works of Young In Germany
I. The Satires
2. The Tragedies

IN GERMANY 


$$
\text { xiv }
$$

3. The Minor Works included in Ebert's Translation of 17541756 • • • • • • • • • 129

4. "Resignation" and Other Minor Works . . . . 132

\section{CHAPTER V}

Bibliography of German Translations, Editions, Reviews, AND NOTICES

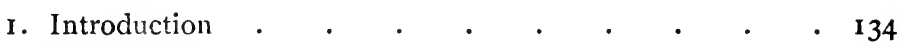

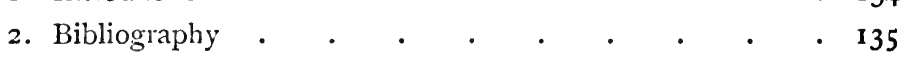

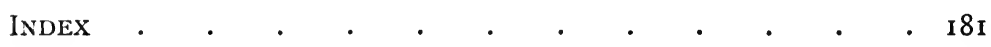


EDWARD YOUNG IN GERMANY 
CHAPTER I

\section{THE "CONJECTURES ON ORIGINAL COMPOSITION"}

\section{Young's Relation to Earlier English Writers of the Eighteenth Century}

THE "Conjectures on Original Composition," which appeared in the spring of 1759 , is one of the most important works on literary criticism written in the second half of the eighteenth century. It was, in a way, the natural outgrowth of the controversy that had been carried on in England since the beginning of the century, as to the relative merits of the ancient classical and the modern writers, and was directed against the so-called Neo-classical School.

Beginning with Dryden and Pope, who considered the ancient classics perfect, or at least superior to the works of later generations, and who recommended imitation of the ancients as the only safe method for modern writers to pursue, themselves setting the example by translating some of the leading works of the ancients, there had been a growing tendency in England to idolize these ancients and to disparage all other works. Naturally, there sprang up an opposition to these views, that gained comparatively little favor, however, until about $\mathbf{1 7 2 5}$, when the revival of Shakspere enthusiasm was well under way, supported by an interest in old English ballads and in the work of such poets as Ramsay and Thomson, who owed but little to the ancients.

The fruits of this reaction, in point of literary form, are best seen in the increasing preference for blank verse and the Spenserian stanza, and in the diminishing use of rime. About the middle of the century the periodicals took up the discussion in articles and reviews, the same reaction was manifested in art criticism, and the results were applied in the domain of letters. 
When, in 1757 , the first volume of Warton's "Essay on the Writings and Genius of Pope" appeared, which was dedicated, it is interesting to note, to Young, and which denied Pope the rank of a great poet, the cause of the moderns seemed in the ascendency. But its triumph did not last long. The discussion was fiercely revived, and the reaction that set in was so intense that the Neo-classical School seemed about to score a complete victory. It was then that Young was urged by his friends to publish his views on the subject, ${ }^{1}$ and the effect of his work was immediate. Warton had already robbed Pope of much of the infallibility attributed to him by his enthusiastic admirers; but now the mortal man was exposed to even clearer view, and an attack was made upon all his confrères as well. But Young's chief service is not in shattering false idols; he is not merely an iconoclast. He makes free use of the results of advanced contemporary thought, collecting and welding it into a brilliant literary whole; he builds, inspires, leads on, and becomes the prophet of the promised land of English letters.

Altho the outcome of the reaction against the Neo-classical School was the emancipation of genius, the supremacy of originality and individualism, Young's essay itself had no prolonged influence in England. It was reviewed and discussed by the leading writers of the day, attracted considerable attention for a time, and then disappeared in the triumph of the reaction which it had helped to precipitate. In Germany, its effect was greater and more lasting, due to the fortunate coincidence that it appeared at a moment of indecision, when the Germans were groping after originals. Thus the doctrine of individuality and original genius, which Young proclaimed, became the watchword of a whole, new, literary school.

\section{Outline of the "Conjectures"}

Young first discusses composition in general. There can not be too much literary composition, he contends, provided that

1 The "Conjectures" were written in 1756 , and the manuscript had been read by Young's most intimate friends before its publication in 1759 . 
it emanates from sound understanding and is written in the real service of mankind. The mind of a man of genius, he declares, enjoys a perpetual spring, and the fairest flowers of that spring are the originals. "Imitations are of two kinds: one of nature, $\downarrow$ one of authors; the first we call originals, and confine the term "imitation' to the second." ' The latter increase the mere drug of books, because they only give us duplicates of what we had, and even when excellent but build upon another's foundation; the debt is equal to the glory, and the "imitator shares his crown, if he has one, with the chosen object of his imitation."

Originals, on the other hand, are great benefactors; they extend the republic of letters, they are of spontaneous growth, and even when mediocre are indebted to no one but nature. Originals are few in number, not because the writer's harvest is over, but because illustrious examples "engross, prejudice, and intimidate." And yet most of the ancients are only accidental originals; for the works they imitated are, with few exceptions, lost. He who does not admire them shows that he does not understand them. Furthermore, we should even imitate them, but imitate aright; i.e. we should "build our compositions with the spirit and in the taste of the ancients, but not with their materials;" and this explains the paradox: "The less we copy the ancients, we shall resemble them the more." We moderns lack ambition or we could equal the ancients; for "have we not their beauties as stars to guide, their defects as rocks to be shunned, the judgment of ages on both, as a chart to conduct, and a sure helm to steer us in our passage to greater perfection than theirs? Too great awe for them lays genius under restraint. . . Genius is a master-workman: learning is but an instrument." Genius is "the power of accomplishing great things without the means generally reputed necessary to that end. . . L Learning . . . is fond and proud of what has cost it much pains, is a great lover of rules, and . . rules, like crutches, are a needful aid to the lame, tho an impediment to the strong." And here a second paradox: "Genius often then deserves most to be praised, when it is most sure to be con-

1 All citations follow as closely as possible the first, original edition of 1759 , with modernized spelling and punctuation. 
demned; that is, when its excellence, from mounting high, to weak eyes is quite out of sight."

Among the moderns, Shakspere is a star of the first magnitude; among the ancients, Pindar. They relied upon their own native powers; genius was the god within them, and so they did not need learning.

There are two kinds of genius: adult and infantine. Shakspere was of the first kind and came from the hand of nature, as Pallas out of the head of Jove, "at full growth and mature." Swift, on the contrary, was an infantine genius, and such genius, "like other infants, must be nursed and educated." In such a case the classics are "our rightful and revered masters in composition"; but the pupils of nature need no such master. Nor is genius as rare as we imagine. Were not the minds of the monks cloistered almost as much as their bodies? Yet we must marvel at their natural sagacity. Many a genius probably has remained undiscovered, because he could neither read nor write.

"By the praise of genius we detract not from learning; we detract not from the value of gold by saying that diamond has greater still. He who disregards learning shows that he wants its aid, and he that overvalues it shows that its aid has done him harm. Overvalued, indeed, it can not be, if genius as to composition is valued more. Learning we thank, genius we revere; that gives us pleasure, this gives us rapture; that informs, this inspires and is itself inspired; for genius is from heaven, learning from man; this sets us above the low and illiterate, that above the learned and polite. Learning is borrowed knowledge, genius is knowledge innate and quite our own. Therefore, as Bacon observes, it may take a nobler name and be called wisdom; in which sense of wisdom some are born wise."

Genius suffers thru the spirit of imitation for three reasons: first, imitation deprives men of letters of the emulation to surpass predecessors. Secondly, it counteracts nature and thwarts her design. She brings us all into the world originals, but that "meddling ape imitation" makes us die copies. Third, imitation "makes us think little and write much."

Modern powers are equal to those of antiquity, but modern 
productions are deplorably inferior. There are reasons why talents may not appear in every epoch, none why they should not exist. "That we may not go a-begging with gold in our purse," Young recommends two golden rules borrowed from ethics: "first, Know thyself; secondly, Reverence thyself." That is, discover and nourish the inherent spark of genius within you, and then prefer its natural products to foreign importations. He who does not do this, on account of too servile admiration of others, can never rise above the throng nor conceive the least embryo of new thought.

"Admiration has generally a degree of two very bad ingredients in it: of ignorance, and of fear," and these raise the pedestal for the "grandees of all kinds." "Imitators and translators are somewhat of this pedestal kind and sometimes rather raise their original's reputation by showing him to be by them inimitable." Homer, in spite of Pope's rimed verses, is still untranslated. And this leads our author to a discussion of poetry and a defence of blank verse. "Harmony," he says, "as well as eloquence, is essential to poesy; and a murder of his music is putting half Homer to death. Blank is a term of diminution; what we mean by blank verse is verse unfallen, uncursed, verse reënthroned in the true language of the gods, who never thundered, nor suffered their Homer to thunder, in rime."

Then Young criticises the writers of the English Neo-classical School. He sees in Swift's satire a monstrous distortion of humanity, a contempt that is a vice. Pope would have done better in an original attempt, but he, alas, not only imitated, but zealously recommended imitation. Thus he has given us only a copy of Homer, whereas the courage and ambition to vie with that Grecian bard might have given us a second Homer - a Pope. But, as Bacon says, "Men seek not to know their own stock and abilities, but fancy their possessions to be greater and their abilities less than they really are." "If," Young resumes, "ancients and moderns were no longer considered as masters and pupils, but as hard-matched rivals for renown," moderns might in time become ancients of even a superior ilk; for an impartial providence scatters talents indifferently in all periods of time, the world is a school for intelligence as well as moral 
advance, and we in our days have the advantage of all the preceding centuries of nature's schooling. From the Britons especially may something new be expected; they seem to need, in order to give us originals, little more "than a consistency of character and making their compositions of a piece with their lives." In fact they already have great originals and of these Shakspere is the greatest. "Shakspere mingled no water with his wine. ... Shakspere gave us a Shakspere, nor could the first in ancient fame have given us more. Shakspere is not their son but brother, their equal, and that in spite of all his faults"; for the ancients themselves are not measured by the fewness of their faults, but by the number and brightness of their beauties.

"Jonson," in the serious drama, is as much an imitator as Shakspere is an original." He was too learned, "pulled down all antiquity on his head and buried himself under it." If Shakspere had read more, he might have thought less, and whatever other learning he wanted, he was master of two books : the book of nature and the book of man. "If Milton had spared some of his learning, his muse would have gained more glory than he would have lost by it." 2 "Dryden, destitute of Shakspere's genius, had almost as much learning as Jonson ${ }^{\mathbf{1}}$ and for the buskin quite as little taste. He was a stranger to pathos," and strove to make amends for it by the elegance of his verse. The greatest proof of his lack of taste is the use of rime, "which, in epic poetry, is a sore disease ; in the tragic, absolute death." It elevates lesser poetry, but debases the greater.

Addison had "a warm and feeling heart," but concealed it thru modesty, and his "Cato" fails thru want of tragic pathos, which is the life and soul of tragedy.

Young then sums up this triumvirate in the following words: "Swift is a singular wit, Pope a correct poet, Addison a great author." Addison wrote sweet, elegant, Virgilian prose, he continues, and his writings are valuable; but more valuable his life, and his death triumphant. Thus Young passes from literary criticism into an extended eulogy on Addison's Christian death.

1 Young wrote "Johnson."

${ }^{2}$ Added in the second edition. 


\section{Critical Consideration of the "Conjectures"}

Young writes in the introduction to the "Conjectures," "I begin with Original Composition; and the more willingly, as it seems an original subject to me who have seen nothing hitherto written on it." Taking him at his word, one might be inclined to look upon the treatise as the embodiment of entirely new thought on a new subject, and hence consider it unnecessary to look for sources of influence. But in view of the lively discussion that had for several decades been carried on in England with regard to the comparative merits of ancient and modern writers, and considering, furthermore, the interest that Young took in the debate, as evinced by his own works, ${ }^{1}$ it would seem strange that all these arguments in favor of originality had escaped him, even in his retirement in Welwyn. The abovequoted sentence, "and the more willingly, as it seems an original subject to me who have seen nothing hitherto written on it," does not belong to the original edition of May, I759, but was added in the second edition. It looks very much, therefore, like a subsequent attempt to give the treatise more weight by claiming for it the stamp of that very originality which it preaches. Furthermore, when upon investigation one sees the extent of his indebtedness to his predecessors and contemporaries, the claim. as made by Young, is all the more curious. At all events, it is a claim that needs the following qualification that has recently been given it by $\mathrm{A}$. Brandl. ${ }^{2}$

Since the time of Ben Jonson it had been generally accepted that Shakspere was a genius without learning. Dryden had called him "the largest and most comprehensive soul of all modern and perhaps ancient poets." ${ }^{3}$ Dryden and Addison had pointed out what they took to be his faults, which Young admits, but passes over lightly. Young's merit is, then, rather his proclamation of Shakspere as an original genius, and yet even this Pope had long ago insisted upon with the greatest emphasis, linking the names of Homer and Shakspere as great

1 W. Thomas: "Le Poète Edward Young." Paris, rgor, pp. 464-465.

2 Jahrbuch der deutschen Shakespeare-Gesellschaft. Vol. XXXIX, pp. I-42.

3 Cf. "Essay of Dramatic Poesy," ı668. 
original writers. ${ }^{1}$ But both Pope and Addison, and Dryden before them, had looked upon Shakspere as inimitable and had warned writers against attempting to walk in his footsteps. This caution Young overrules, urging that Shakspere, or rather his independent way of studying and depicting nature and man, should be imitated. This is the main point of Young's essay as regards Shakspere

The relation of genius to learning, too, had long been the subject of discussion, and since the time of Ben Jonson learning had had rather the best of it. Poetry was conceived as the imitation of nature thru the imitation of the best literary models, and literary criticism undertook to regulate the mutual relations of the two. Pope's "Essay on Criticism" (I709-I7II) is the classical expression of this theory Addison, in the Spectator (I7II), classified genius as natural and cultivated: the first represented by Homer, Pindar, and Shakspere, the second by Plato, Aristotle, Virgil, Cicero, Milton, and Bacon. Thus he placed the writers of natural genius that Pope called exceptions, and in whom "a nameless grace" and fortunate "licence ... snatch a grace beyond the reach of art," ${ }^{2}$ in a class which he considered equal to the second, i.e. equal to the writers of learned genius. Shaftesbury, in his "Characteristics" (I III), likewise distinguished the same two kinds of genius. He even attributed the scarcity of the products of natural genius in modern times to the abundance of literary models, anticipating Young's diatribe against servile imitation. But Addison wisely applied the classification to the then lively controversy concerning ancient and modern writers, and to the kindred question, the valuation of Shakspere as an original genius. Addison's merit is, further, that he conceded to this natural genius "something nobly wild and extravagant, a heat and life of the imagination, greatness, and daring," such as Shakspere evinces in his wonderful portrayal of supernatural beings. ${ }^{3}$ This fortunate concession gained a considerable following, ${ }^{4}$ which steadily in-

1 Edition of Shakspere, I725.

2 "Essay on Criticism," verses I44 ff.

${ }^{3}$ Spectator, No. I60, I 7II. Cf. also his essays, 4II-42I, I 7 I 2.

${ }^{4}$ Cf. Jahrbuch der deutschen Shakespeare-Gesellschaft, l.c. pp. 5-6. 
creased, so that by the time Young published his views it had become a commonplace of critics that the writer who wishes to be original must be able not only to discover, but also to invent something new out of his own imagination.

The classification of genius as adult and infantine dates back to Addison. ${ }^{1}$ The preference for originals was the common preference of the more advanced thinkers, and so Young advanced beyond them only by contending that modern writers can and should be originals: first, by knowing themselves; secondly, by reverencing themselves. But Bacon, in his "Advancement of Learning" (I605), had already hinted at this, and hence Young's only merit is that he took these precepts from ethics and applied them to literary esthetics.

Further, in recommending the imitation of the spirit of the ancients, as distinguished from imitation of their works, Young solved the problem of the relative merits of the ancients and the moderns, by according to each their due: to the ancients reverence, to the moderns freedom. Richardson immediately pointed out the fact that Young's distinction between performance and power was not entirely new, but was found in Warburton. Young's merit is, therefore, the more universal application of this thought of Warburton, which the latter had used to defend Pope.

Young's value, then, lies not so much in the presentation of new thought, as in summing up and promulgating with a special, new application the most advanced critical opinion of the times, in a manner that was unprecedented, and with an ardor that drew attention at once to the principles involved and assured to them the consideration of all enlightened minds.

In regard to literary form, the "Conjectures" show the same lack of clearness of expression and orderly arrangement of material, so noticeable in the "Night Thoughts" and previous works. Their greatest irrelevancy, however, is the extensive eulogy on Addison's Christian death, beautiful in itself but out of place in a work on original composition. For if the essay is to be regarded as a treatise on literary criticism, this long digression is not needed; and if, on the other hand, the work was

${ }^{1}$ Spectator, No. I60, I 7 II. Cf. also his essays, 4II-42I, I 7 I2. 
written merely, as Young himself says, to bring before the public this inspiring death-bed scene, then the title is a misnomer, and the greater part of the work is irrelevant. That he insisted upon including this eulogy in spite of Richardson's protest, shows that Young, even when presuming to write upon literary matters, was primarily a moralist, a preacher. As such he appears in the "Night Thoughts"; and here, fifteen years later, we have a continuation of his favorite theme, the "Christian Triumph."

On the other hand, the work contains a wealth of picturesque similes and metaphors, powerful antitheses, convincing exhortations, and startling paradoxes, which give the treatise a brilliancy and vigor that make it now the most pleasing work from Young's pen, and paved its way a century and a half ago to success in both England and Germany. 


\section{CHAPTER II}

\section{THE "CONJECTURES ON ORIGINAL COMPO- SITION" IN GERMANY}

\section{General Survey of German Thought on Original COMPOSITION PRIOR TO I760}

IF in England the "Conjectures" were the product of the times and represent the culmination of a long period of literary criticism, in Germany they opened a new epoch in critical and creative activity, an epoch that was to be the most important in the whole history of German letters. But even here they did not come unheralded; the way had been in a measure prepared.

The early discussion of modern original genius, as opposed to the ancients, goes hand in hand with the introduction of Shakspere into Germany. Koberstein ${ }^{1}$ has sketched very carefully the gradual dawn of that great dramatist upon the Germans, and it is not necessary to repeat the details here. Suffice it to say that up to 1740 Shakspere was known only by name and at that in an incorrect form. Emending the abbreviation of the name in the Spectator, Bodmer wrote it "Saspar" and "Sasper." The next year "Julius Cæsar" was translated by Borck into Alexandrines, a fair piece of work, which, however, suffered a bitter attack from Gottsched. Zedler's "Universal Lexicon" of I743 calls Shakspere a successful poet without "special learning." Gottsched's periodicals mention him often from I745 to I755, recognizing him as a genius, too faulty, however, to please that sturdy partizan of the French drama. But these

1 "Shakspeare's allmähliches Bekanntwerden in Deutschland," etc. In "Vermischte Aufsätze zur Litteraturgeschichte und Aesthetik." Dr. August Koberstein. Leipzig, I858, pp. I65 ff. 
views were based entirely upon the translation of one tragedy, Borck's rendition of "Julius Cæsar."

In 1753, the periodical Neue Erweiterungen der Erkentniss und des Vergnügens also recognizes Shakspere's genius, and, altho it deplores the fact that he did not know the ancients, it gives him credit for good taste and admits that a knowledge of the ancients might have intimidated his own genius. Being ignorant of acquired art, the critic declares, Shakspere followed nature; for the latter spoke more thru him than he according to her. In $175^{6-1} 75^{8}$, fragments of Shakspere's plays were translated from the French.

As long as Gottsched ruled the German stage, Shakspere could make little progress in Germany; and, altho Bodmer and Breitinger had dispossessed the Leipzig arbiter elegantiarum of much of his prestige after the opening of their feud in I740, the Swiss alone could not depose him as dramatic authority; other forces had to be enlisted - the ancients and the English.

Lessing's "Miss Sara Sampson" (1755) gave the practical example necessary, and Nicolai's "Briefe über den itzigen Zustand der schönen Wissenschaften in Deutschland," the same year placed in a clear light the advantages of the English for the German stage. Nicolai attacks Gottsched's antipathy to the English dramatists, and he too speaks of Shakspere as "a man without knowledge of rules, without learning, without order," and sees his strength in his power to portray human nature. But it was reserved for Lessing to drive Gottsched completely out of the field. In the Litteraturbriefe (1759) ${ }^{1}$ he unjustly denied that former arbiter all recognition as a reformer of the German stage and expressed the wish that Gottsched had never meddled with the theater; for his reforms, when not actual deteriorations, concern only trifles of no moment. [Discussing Shakspere, Lessing insists that the English dramatist is superior to Corneille, even when judged by the standards of the ancients themselves, whom he scarcely knew. Corneille may be more similar to the ancients in technique, but Shakspere is more like them in spirit, and, no matter what his method, he

${ }^{1}$ Cf. the 17 th "Brief," Feb. 16 , 1759 . 
nearly always succeeds in attaining the purpose of tragedy. Young's "Conjectures" appeared the same year, confirming, directly from the land of Shakspere, the opinion of Lessing; and Shakspere's future was assured in Germany.

The idea, then, that Shakspere was a genius without learning, an idea familiar in England since the time of Ben Jonson, was also introduced into Germany, in the Spectator, simultaneously with Shakspere's very name. Bodmer first met it in a French translation of Addison's periodical, but it was not until the first German translation of the Spectator appeared in $1739^{-}$ I 743, edited by Gottsched's worthy spouse, that the connection of Shakspere's name with that of Homer called attention to the merits of that inimitable genius, to whom rules were unknown and whose dramas, nevertheless, contained more beauties than the writings of shallower brains who knew and observed every rule. $^{2}$ Pope's "Essay on Criticism," translated by Drollingerand published in I74I, also taught the Germans to look upon Shakspere as an original who spoke not of nature, but thru her, a genius who had his faults. But going further, Pope proclaimed that the rules of Aristotle must not be used to judge Shakspere's dramas; that, he insisted, was like judging a man according to the laws of a country of which he is not a citizen. ${ }^{3}$ Other writers, probably from the same source, knew Shakspere's secret.

But not only in their attitude toward Shakspere were the Germans prepared for Young's "Conjectures." J. E. Schlegel, in discussing the subject of imitation, anticipates Young's distinction between imitation of nature and imitation of authors. ${ }^{4} \quad$ But he limits his discussion to the former as true imitations; whereas Young confines the term "imitation" to imitations of authors, and calls imitations of nature "originals."

Still more important is the advance made by Johann Adolf

1 Cf. supra, p. 7.

${ }^{2}$ Cf. Spectator, No. 592, I 7 I4.

${ }^{3}$ Cf. Gerstenberg, infra, pp. 23-24; Hamann, infra, p. 38; Herder, infra, p. 42.

4 "Abhandlung von der Nachahmung," r742. To be found in "Deutsche Litteraturdenkmale des 18 . und 19. Jahrhunderts." Vol. XXVI, pp. 107-108. 
Schlegel in his translation of Batteux's treatise "Les BeauxArts réduits à un même principe," in $\mathrm{I} 75^{\mathrm{I}} \mathrm{I}^{1}$ and in his notes to that translation. This work teaches Young's doctrine that the ancients should be our prototypes, whereas we have made them our lawgivers. To understand and appreciate the ancients, he says, we must be thoroly acquainted with their conditions, and not find fault because they do not comply with our ideas and customs, which were, of course, unknown to them. ${ }^{2}$ He deceives himself, he continues, who considers as a criterion of good taste what is only prejudice in favor of the ancients, - a sentiment that later turns up in Herder. ${ }^{3}$ We find here, too, as later in Young's "Conjectures," imitation of nature ranked above imitation of the ancients, in the advice: do the latter, if you have not the ability to do the former. ${ }^{4}$

What would have been accomplished without the inspiration of Young's "Conjectures" is a matter for speculation; but it is plain that the Germans, having tired of following the French with Gottsched in the lead, and then the English with Bodmer, and the Swiss, were realizing the necessity of doing neither. Lessing's claim for the ancients could not even suffice, and they were beginning to feel that to write correctly they must not imitate at all. Thus Young, with his doctrine of originality, came in the very nick of time; he pointed out Shakspere as the great original genius of modern times, a genius who created with his own powers and followed no one. For the rising generation Shakspere and the ancients became irreconcilable opponents; and Shakspere, typical of the possibilities of modern original genius, became the watchword of a new epoch in German letters.

\section{The Translations of i 760 and i 787}

The "Conjectures" appeared in the spring of $1759,{ }^{5}$ and by fall Young had published a revised edition. Owing to the popularity of Young at that time among the Germans, it was

1 “ Einschränkung der schönen Künste." Second edition, I759; third, I770.

${ }^{2}$ Cf. the third edition. Vol. I, p. 77. Cf. infra, pp. 23-24.

${ }^{3}$ Cf. ibid., Vol. II, p. Io7. On Herder, cf. infra, pp. 47-48.

${ }^{4}$ Cf. l.c. Vol. I, p. I22.

${ }^{5}$ Cf. supra, pp. I, 2, 7 . 
natural that the latest work from his pen should find its way into Germany immediately. Gerstenberg's reviews in the Bibliothek der schönen Wissenschaften und der freyen Künste, in the late summer of 1759 , would tempt one to look for influence of the "Conjectures," and to infer that that critic had already read Young's work in the original. ${ }^{1}$ But so much is certain: the work had come over to Germany early enough to allow Teubern to have his translation almost ready for the press by February, 1760. The Leipzig Neuer ${ }^{2}$ Zeitungen von GelehrtenSachen contains the first notice of the "Conjectures," - a résumé and favorable review of the work, with the announcement that a German translation is about to appear in Leipzig. ${ }^{3}$ This translation did appear shortly, signed by "v.T.," who was the Dresden Court Counsellor, Hans Ernst von Teubern (1738I80I). In the introduction he speaks of Young in the highest terms and confesses that he considers the task of translating so sublime a work a great undertaking and one to be held in awe, in view especially of Ebert's excellent work. This translation is made from the second English edition and follows the original very closely. A second edition, a reprint rather, of this translation appeared in $176 \mathrm{r}$, also in Leipzig.

The year I 760 had also brought forth a different rendition by a translator who signed himself "G.*" This was published in the Freymüthige Briefe of Hamburg. The notice of the work of which "Young is said to be the author" 4 shows that this translator used the first edition. The introductory remarks find fault with the style of Young's epistle, especially considering it as a "letter." This translation seems to have attracted much less attention than the first one.

Gottsched, who had shown a very kindly attitude toward the "Night Thoughts," reviewed Teubern's translation, soon after its appearance, in his periodical Das Neueste aus der anmuthigen Gelehrsamkeit and was very enthusiastic over Young's style.

${ }^{1}$ Cf. infra, p. 23.

2 Titles are given as found upon the title-page.

${ }^{3}$ Works that can be easily found under their dates in the Bibliography, Chapter V, are not mentioned in these footnotes.

4 The first edition, March, I759, had appeared anonymously. The second edition bears Young's name. 
But the subject-matter! "Young should rather have continued to apply his imagination to the production of gloomy 'Night Thoughts," he says, "or to the creation of specters, ghosts, and witches' conclaves to frighten children; instead of meddling with a treatise on critical matters, upon which he is not competent to throw any light." Yet at the end of his tirade Gottsched finds himself constrained to admit that Young has said many good things, and that the translator has furnished a good reproduction; still the critic can not but express regret that the translator did not apply his talents to another author, e.g. Shaftesbury.

This brought down upon Gottsched's head the righteous indignation of Nicolai in the Litteraturbriefe of the following year. Nicolai says that he is not by any means an ardent admirer of Young, especially of his prose; but in the "Conjectures," he declares, Young writes as one of the greatest original writers. The "Conjectures" is an admirable treatise "Everywhere new and strange light is thrown upon the subject, the work abounds in excellent features, new remarks, profound thoughts, pithy opinions, correct decisions; much wit, and still more humor," etc. Such criticism as Gottsched's is the work of a blockhead, says Nicolai.

The Bremisches Magazin, the same year, contains in translation, an article on the "Conjectures," from the May number (I759) of the Gentleman's Magazine, without mentioning either one of the German translations. But the Bibliothek der schönen Wissenschaften und der freyen Künste, reviewing the work as a treatise written in a style so brilliant that it would do credit to an ardent youth, mentions the two German translations and thinks the work already so well known in Germany that nothing more need be said about it. The Göttingische Anzeigen von Gelehrten Sachen reviewed the second edition of Teubern's translation with praise for both the translator and Young.

A discussion, in the Beytrag zur Litteratur und zum Vergnügen, ${ }^{1}$ of the literary supremacy of Greece and England mentions Milton, Pope, and Young, and quotes from the "Conjectures" to prove its points. Schmid's "Theorie der Poesie" ( 1767 )

${ }^{1}$ Halle, I766. Cf. pp. 8, 18; also pp. 22-43. 
expresses the ardent wish that all poets and orators might take Young's "Conjectures" to heart and endeavor to become immortal originals.

But not all joined in this admiration of Young and his views. Gottsched found some support, especially in the person of J. J. Rambach, who, in a Schulprogramm of 1765 , attacked the contention that the study of the ancients is responsible for the lack of original writers in modern times. It is a long-winded discussion of some forty-five pages, advocating the study of the ancients to cultivate taste and literary genius. Rambach takes up Young's principal arguments, point for point, and tries to refute them. He says that Young, a thoro master of the ancients, was nevertheless a good original, which is contradiction enough.

This attack upon Young was responded to by no less a critic than Herder, in a very sharp review that ought to have settled the question in Young's favor. ${ }^{1}$ But it did not have that effect. Two years later two writers raise the same question. One, in the Gelehrter Mercurius, discusses Young's contention that the illustrious examples of the ancients intimidate us and prevent us from developing our own powers. Can the ancients not be read as a means of developing our taste and inspiring our genius, the critic inquires. This review announces Meusel's article on the advantages of reading the ancients, a work which appeared soon after and carried this criticism of Young still further. ${ }^{2}$

But Young's forces received new strength, when, in I770, Cramer's periodical, Der Nordische Aufseher, which had only two years before paid the "Night Thoughts" a most eulogistic tribute, ${ }^{3}$ expressing a desire to give its readers some selections from the "Conjectures," printed an eleven-page résumé of the work, with lengthy and favorable criticisms. Numerous bibliographies, works on the theory of poetry, esthetics, criticism, and the like, contained reviews of the "Conjectures" up to the end of the century, none of which, however, added anything of interest or importance. One might deserve special mention. The

1 Cf. on Herder, infra, pp. 41-42, 47.

2 "De Veterum Poetarum Interpretatione," I 767. ' Cf. infra, pp. 66, 83-84. 
Englische Blätter, published by Schubart (I794), contains an interesting article on the natural inclination of man to imitate. The British are the ones, he says, among whom originality has prospered best, and yet their writers have found it necessary to preach to them on imitation. What shall we say to the goodnatured German, who scorns his own treasures and is everlastingly chasing after the tinsel of foreign lands? The article cites Young's saying that altho we are all born originals yet most of us die copies, and refers to Young as "der Schöpfer der Nachtgedanken" (!). The same work, Vol. XII, contains a translation, from the Gentleman's Magazine, of an article on original genius and a discussion which recommends originality as the only road to lasting fame.

And yet, in spite of this widespread acquaintance with the work, and notwithstanding these numerous discussions and the writings of Hamann and Herder, the three German editions of I760-I76I did not reach all quarters of Germany. In 1787 , a person signing himself " $\mathrm{C}$," published a version in Leipzig under the title "Ueber den Geist der Originalwerke," in the very city where, twenty-seven years before, Teubern had published his two editions. "C" thought he had made a new discovery, as we read in his introduction, and he felt that he ought to allow this book by this original genius to speak to the German people in their own language. The rendering follows the first edition of the spring of $\mathrm{I} 759$, and renders Young's work very freely, that being C's theory of a correct translation. This book seems to have met the deserved fate of attracting little attention. A belated review appeared in the supplement to the Allgemeine deutsche Bibliothek (I79r) of books that had been overlooked upon their appearance. It comments upon C's ignorance of the earlier translations and shows that altho his rendering is free, it is nevertheless obscure in places. A passage is placed in parallel columns with the translation of 1760 , to show the superiority of the latter. Further, the reviewer accuses the anonymous translator of a meager knowledge of English and of being unable to write correct German. Here, then, we have the last belated prophet of the "Conjectures" in Germany, appearing almost thirty years too late, thirty years after Hamann and 
Herder had begun their campaign against servile imitation and had guided the leading writers of Germany into safe paths of original production.

\section{The Litteraturbriefe and the IDEA OF ORIginality (1759-1765)}

In the fifty-eighth "Brief" Nicolai opens the campaign against imitation and for the cultivation of original genius, by denouncing Germany as the home of imitators. ${ }^{1}$ The prevailing imitation, he says, is of modern writers; the young poets do not venture so far as to imitate the ancients. Germany has real originals, but they are so few in number that one could wish that the mediocre talents, so possessed are they by the desire to imitate, would at least imitate better, if they can not write in an original manner. The same critic, the next year, ${ }^{2}$ expresses himself a little more definitely in favor of original genius, when he says that genius to become sublime must be able to control itself, must not lose its rudder in the storm of passions; and that improvement thru criticism and revision is laudable in the works of a genius, ${ }^{3}$ - thus admitting that even genius can profit by learning, as Young says. ${ }^{4}$

In the year of their appearance, Young's ideas on original composition seem also to have made themselves felt in Mendelssohn's objection ${ }^{5}$ to Sulzer's statement that no one should venture to be an original, who has not read the ancient Latin and Greek writers. Mendelssohn is surprised at such an opinion and avers that the observation of this rule would have robbed us. of all the works of Shakspere. "Genius," he says, "can compensate for the lack of rules, but nothing can compensate for the lack of genius." This clearly is a repetition of Young, who

1 1759, pp. 207-209.

2 Cf. the 92d "Brief," p. $220,1760$.

${ }^{3}$ Cf. ibid., p. 222.

"Cf. "Complete Works," edited by Doran. London, 1854. Vol. II, p. 560.

- Cf. the 6oth "Brief," p. 222, 1759. It is also worthy of note that Young's essay on Lyric Poetry ( 1728 ) was translated into German in 1759 . This contains Young's ideas on originality in the germ. Cf. Bibliography, infra, 1759. 
says: "To neglect of learning, genius sometimes owes its greater glory. ... Genius can set us right in composition without the rules of the learned; . . . singly, as writers, can sometimes make us great." 1

The supremacy of genius is further proclaimed in the two hundred and fifty-fourth "Brief," 2 where to this very superiority to rules is attributed the cause of the erratic flights and falls of genius, writing "now for angels and now for children." Like Young, the critic remarks that the more genius one has, the further one may wander away from the beaten path; but unfortunately, he continues, this desire to go one's own way, in order to become an original, has misled some of the best talents into woful errors. And, speaking of the genius of the ancients, Mendelssohn ${ }^{3}$ uses a comparison that later appears in Herder. ${ }^{4}$ He says, namely, that the ancients seemed to lack a word for Genie, but so much is certain, they showed more genius than the modern critics who constantly have the word on their tongues.

In the last year of the Litteraturbriefe Mendelssohn writes: with taste, judgment, and criticism one may become a really good poet, but not on that account a poetical genius. He ranks genius above mere taste, judgment, and criticism in poetry, altho he admits that these qualities can produce excellence in prose. ${ }^{5}$ Further, he shows that the "Conjectures" were fresh in his mind, when he writes, "And so an Addison can produce really good poems without poetical genius and be excellent in prose writings." 6

Finally, Resewitz takes up the discussion of genius with the sarcastic remark that there must be an abundance of genius among the Germans, judging by the amount of talk on that subject. $^{7} \mathrm{He}$ corroborates Baumgarten's definition of genius as the skill in man to accomplish certain things with exceptional

\footnotetext{
1 "Complete Works," edited by Doran. Vol. II, pp. 556-558.

${ }^{2}$ I 762 , p. 173 .

${ }^{3}$ Cf. the $92 d$ " Brief," p. $21 \mathrm{I}, \mathrm{I} 760$.

4 Cf. infra, p. 56.

"Cf. Young: "There is something in poetry beyond prose reason," etc. "Complete Works," edited by Doran. Vol. II, p. 557.

"Cf. the 3 r2th "Brief," p. I38, I765; also Young's "Complete Works," Vol. II, pp. 575 ff. $\quad{ }^{7}$ Cf. the 3 I $7^{\text {th }}$ "Brief," p. 2 I, I765.
} 
success. ${ }^{1}$ Only great geniuses work their way up thru false conditions, he says, whereas mediocre geniuses succumb. And later, in the same "Brief," ${ }^{2}$ he says, like Young: A genius strikes into new, untrodden paths and shows thru new examples that there are more roads than those already prescribed; but a genius must not depart from the rules that are exacted by the nature of the material treated. There are rules that are capricious and indefinite, and to these genius does not confine itself, unless it limits their application thru the new turn it gives to them. There are rules that are, to be sure, valid; but they are deduced from the method of individual geniuses and are forced upon all geniuses as universal, necessary rules. Common geniuses subject themselves to this yoke, but geniuses who are conscious of their own powers supersede these rules and show the philosophical lawgiver that these limitations must be extended, if his authority is to remain valid. But the imagination of the genius must be combined with observation of rules that arise from the exigencies of the case, or else the genius will go astray. If Shakspere had observed this regularity in his tragedies, he would have become even greater. He admits nevertheless, as Young does, that the anxious observance of rules weakens the ardor of genius and even kills it, but he does not overthrow rules entirely, as Young is inclined to do, and as Hamann and Herder advocated later; and yet he admits that the vivid imagination of a well-balanced genius maintains its equilibrium, unconscious of its rules.

Scarcely had the Litteraturbriefe ceased to appear ( $\mathrm{I}_{7} 6_{5}$ ), when two other critics, realizing that there was still much to be done, commenced to publish their views on the state of German letters for the purpose of reform. It is very evident from the preceding sketch that the Litteraturbriefe reckoned with Young's "Conjectures" in their own critical work, but these critics are the forerunners of the Geniekult in Germany rather than its Messiahs. Their work was that of the iconoclast: they shattered the idols of the past and showed what was wrong, but it was left for the future critics to advocate what was right.

${ }^{1}$ Cf. ibid., p. 22; also Young, l.c. pp. 556-558. ${ }^{2}$ Cf. ibid., pp. 50-51. 
Herder felt himself to be this Messiah, and at once began his fragments "Ueber die Neuere Deutsche Litteratur" (I767). ${ }^{1}$ In the introduction he refers to the Litteraturbriefe, when he says mere scolding and fault-finding will not reform German literature, that a practical example is necessary. This he found in Young's "Conjectures," and from that time on the ideas of Young were taken as the watchword of the reform promulgated by Hamann and Herder, the principal figures in this movement, and the doctrine of originality was able to gain the hearing that it deserved. But before we consider in detail the merits of Hamann and Herder in the reform of German letters, we must sketch the preliminary endeavors of the other critics who continued the work begun by the Litteraturbriefe. Shortly before Herder's "Fragmente" began to appear, another series of articles attracted the attention of men of letters, - Briefe über Merkwürdigkeiten der Litteratur, usually called the Schleswigsche Litteraturbriefe, from the place of publication. The author was the rising young poet and critic, Gerstenberg.

\section{Heinrich Wilhelm von Gerstenberg (i 737-I823) and THE Schleswigsche Litteraturbriefe (I 766)}

Gerstenberg, follower of J. A. Schlegel and pupil of Hamann, was in thoro sympathy with the views of original genius and individualism as outlined in the "Conjectures." His acquaintance with Young's works is attested by the comparison of the "Revenge" with Shakspere's "Othello," and the claim of influence of Young's "Night Thoughts" upon the Danish poet Tullin. $^{2}$ His early reviews in the Bibliothek der schönen Wissenschaften und der freyen Künste reveal a reasonable attitude toward the ancients, when he says, writing of the drama, that the ancients portray life according to their times and customs; their works are the most beautiful copies of nature, but of an antiquated nature that can affect us only as critics. ${ }^{3}$ This

\footnotetext{
${ }^{1}$ Herder himself called them "Eine Beilage zu den Briefen, die neueste Litteratur betreffend," on the title-page.

${ }^{2}$ Cf. infra, pp. 24,97 .

${ }^{3}$ Cf. the review of Lessing's "Philotas." Bibliothek der schönen Wissenschaften und der freyen Künste. Vol. V, ii, p. 313.
} 
J. A. Schlegel had already said, ${ }^{1}$ and Herder later repeated. ${ }^{2}$ In the same volume Gerstenberg says regarding the rules laid down for the idyll, "Real genius often has no law but itself; if it is accompanied by taste and knowledge, however, it can always find means of becoming reconciled with sound criticism." 3 In the great stress laid upon the superiority of genius, one is inclined to see an echo of the watchword of the "Conjectures,"

The next critical work of Gerstenberg, the moral weekly Der Hypochondrist, ${ }^{5}$ shows him a disciple of Hamann, in that he sees the true essence of original genius in a certain obscurity ${ }^{\circ}$ and, in the introduction to his translation of Beaumont and Fletcher's "Bride," 7 Gerstenberg follows Young and Home, ${ }^{8}$ when he says it is ridiculous to demand of an author the observation of rules that do not apply to him and his purposes. ${ }^{9}$

But to come to Gerstenberg's principal work as critic, the Schleswigsche Litteraturbriefe. Here, too, we find him, in style, conception of genius, and hostile attitude toward the ancients, under the influence of Young and the latter's disciple, Hamann. The conditions that he is trying to improve Gerstenberg sums up, when he deplores the fact that genius finds few admirers among the Germans, who even feel according to rules, not because their feelings are so regular, but because it would cost too much effort to be original. ${ }^{10}$

The purpose of comparing the moderns with the ancients and of opposing them to each other, taking Shakspere as a criterion,

${ }^{1}$ Cf. Alex. von Weilen, in "Deutsche Litteraturdenkmale." Vol. XXX, p. xviii. Cf. also supra, p. I4.

${ }^{2}$ Cf. infra, p. $45-48$.

3 Cf. Bibliothek der schönen Wissenschaften und der freyen $K$ ünste. Vol. V, ii, p. 3 I9.

"It is not impossible that the "Conjectures," published March, I759, had found their way into Gerstenberg's hands during the summer. Cf. supra, p. 15, on Mendelssohn, p. 19.

5 Published in Schleswig, 1763 .

- Cf. Alex. von Weilen, l.c. Vol. XXX, p. xxvi.

7 December, I764.

8 "Elements of Criticism," I760. Translated by J. N. Meinhardt, I763I766. Cf. also, supra, p. I3.

" "Schreiben an Herrn Weisse," p. 9. Cf. Alex. von Weilen, l.c. p. xxx.

${ }^{10}$ Cf. the Schleswigsche Litteraturbriefe, in "Deutsche Litteraturdenkmale." Vol. XXIX, p. r6. 
is clearly seen thruout the work. Carrying out Young's own principle, not to compare Shakspere with Sophocles, Gerstenberg measures him by his imitators; and so Young's own tragedy, "The Revenge," was submitted to the test and was used to prove the superiority of its model, "Othello." 1 Altho Gerstenberg evidently accepts the classification of dramatic composition in the noted rehearsal scene in "Hamlet," 2 and thus tries to show that Shakspere's tragedies have certain principles in common with the Greek tragedies, in the essay "Etwas uber Shakespeare" (I 766), rescinding that very classification, he exclaims: "Away with the classification of mere names! Name what Shakspere wrote ... as you will. I call his dramas living pictures of ethics from the hand of a Raphael." 3

In ${ }_{1764}$, Gerstenberg had already pronounced it ridiculous to judge a work by the rules of another. ${ }^{4}$ In the Schleswigsche Litteraturbriefe we find the same theme treated more extensively and more clearly defined. Ariosto has been unjustly criticised, Gerstenberg insists, according to rules to which he was not subject; for as a matter of fact, he treated the most interesting material of his times as Homer had done in his, drawing natural pictures. Both are on a par. ${ }^{5}$ Later, he returns to the same theme in discussing Warton's criticism of Spenser, and, after advising critics to become acquainted with the times in which the writer under consideration lived and wrote, he says: "We live in the days of criticism, when every one writes according to rules, and so we are too much inclined to judge every composition by the rules that our tutors have recommended as the only criteria of perfection. Critical taste is spread broadcast, and we demand in the works of modern writers the observation of rules, even where they were not intended to apply." " And turning this principle upon the English, he advises them to cultivate their national feeling in criticism, also, and to abandon

${ }^{1}$ Cf. infra, pp. 125-126.

${ }^{2}$ Cf. Act II, Scene II.

${ }^{3}$ Cf. Gerstenberg's "Vermischte Schriften." Altona, I8I6. Vol. III, pp. 268-269.

${ }^{4}$ Cf. supra, p. 23.

${ }^{5}$ Cf. Schleswigsche Litteraturbriefe, l.c. p. I9.

${ }^{\circ}$ Cf. ibid., p. $4 \mathrm{I}$. 
the prevailing method of using as criteria the leading French writers, who wrote for the French and not for English conditions and taste. ${ }^{1}$

Like Young, Gerstenberg considers genius a quality inherent within us, ${ }^{2}$ and places it above mere invention and novelty, in the following words: "Where there is genius we find invention and novelty, and there is the original; but not vice versa." 3 $\mathrm{He}$ had before drawn the distinction between originals and imitations, showing his preference for the former, when, considering the natural beauties of Sophocles, he pronounced them superior to the best imitations that Corneille was able to create after them. "The latter shows the artist, the former the Greek. We can all be artists, but how rare a Greek!" "

In the third part of the Schleswigsche Litteraturbriefe, Gerstenberg again takes up the question of genius and states his views at some length. ${ }^{5}$ Here he again gives it a position above learning, like Young, and calls it the inborn power that animates everything: imagination is not genius, but its indispensable concomitant. He declares that he honors the ancients, but will not allow himself to be so prejudiced by their genius that he can not recognize modern genius merely because it appears in a new garb." He honors and admires the ancients inexpressibly, as well as the master hand that can imitate their perfections; but the rare exalted mind that is bold enough to become an original, who desires the praise of his nation to be due to his own inner worth and not to comparison with others, he alone is worthy of real admiration and is to him (Gerstenberg) what the ancients have been to the past. The faults of such modern geniuses are as pardonable as those of the ancients. ${ }^{\circ}$

Gerstenberg is, then, a champion of originality, an admirer and advocate of modern genius. In giving Shakspere first rank among the exemplars of this genius, and in recommending the great dramatist's method of original study and portrayal of

${ }^{1}$ Cf. ibid., pp. 43-44.

${ }^{2}$ Cf. ibid., p. 3 ; also Young's "Complete Works," edited by Doran. Vol. II, pp. 556-557.

${ }^{3}$ Cf. Schleswigsche Litteraturbriefe, l.c. p. $228 . \quad{ }^{5}$ Cf. ibid., pp. 215 ff.

1 Cf. ibid., p. I5.

- Cf. ibid., p. 45. 
nature based upon individual observation, Gerstenberg was a follower of Young's "Conjectures" and became a very important factor in the further development of the serious struggle for the advancement of German letters along the lines of individuality and originality.

\section{The Idea of Originality in the "Hamburgische Dramaturgie" ( $1767-\mathrm{I} 768)$}

What Lessing says of Shakspere in the seventy-third "Stück" of the "Hamburgische Dramaturgie" voices Young's requirement that later writers imitate not Shakspere but Shakspere's method. Lessing says: "Shakspere must be studied, not plundered. If we have genius, Shakspere must be to us what the camera obscura is to the landscape painter. Let him gaze intently and industriously into it to learn how nature in all her aspects is projected upon one plane; but he must borrow nothing from it."1

Young said: "Learning, destitute of this superior aid (the divine quality of genius), is fond and proud of what has cost it much pains; is a great lover of rules and boaster of famed examples. As beauties less perfect, who owe half their charms to cautious art, learning inveighs against natural unstudied graces and small harmless inaccuracies, and sets rigid bounds to that liberty to which genius often owes its supreme glory, but the no-genius its frequent ruin. For unprescribed beauties and unexampled excellence, which are characteristic of genius, lie without the pale of learning's authorities and laws; which pale genius must leap to come at them; but by that leap, if genius is wanting, ... . we lose that little credit which possibly we might have enjoyed before." 2 Likewise, Lessing says, "Das Genie liebt Einfalt, der Witz, Verwicklung." 3

Like Young, Lessing gives to genius a rank superior to learning and acquired knowledge and skill in all things, and su-

\footnotetext{
1 "Hamburgische Dramaturgie." Cf. Lachmann-Muncker edition. Vol. $\mathrm{X}$, p. 95 .

"Complete Works," edited by Doran. Vol. II, pp. 556-557.

3 "Hamburgische Dramaturgie," 3oth "Stück." Lachmann-Muncker edition. Vol. IX, p. 309. Cf. also on Hamann, infra, p. 34 .
} 
perior to the rules that usually are observed as a guide; for example, "Genius laughs at all the demarcations of the critic," 1 and "A fortunate genius has great power over his people." 2 But Lessing is not in sympathy with the school of German critics (and he probably refers to Gerstenberg, Herder, and Hamann) who cry, Away from rules : they weaken and limit genius. He writes: "We have a race of modern critics, whose best criticism consists in their ability to make all criticism suspicious. 'Genius! Genius!' they cry. 'Genius transports itself above and beyond all rules! What genius creates is law!' Thus they flatter genius, I believe, in order that they themselves may be considered geniuses by us. But they betray too clearly the fact that they have not one spark of genius within them when they add in one and the same breath, 'rules crush genius!'As if genius would allow itself to be crushed by anything in the world! And especially by something which, as they themselves admit, has been derived from genius itself. Not every critic is a genius; but every genius is a born critic. He has the criterion of all rules within him. He comprehends and preserves and follows only those which express his feelings in words. And these feelings expressed in words are able to restrict his productivity? ... To contend that rules and criticism can oppress genius, ${ }^{3}$ is merely claiming, in other words, that examples and practice are able to oppress genius; that genius must have recourse not only to itself, but can not advance beyond its first attempt." 4

Again, he occupies an attitude opposed to Young and his German disciples, when he insists that rules are necessary at all events. "Dramas that do not observe classical rules can nevertheless observe some rules, and must observe them, if they wish to find favor." 5 And at the close of the "Dramaturgie," Lessing expresses the same antipathy toward those who wish

1 Cf. ibid., $7^{\text {th }}$ "Stück," p. 2 ro.

2 Cf. ibid., I4th "Stück," p. 240.

3 This had been asserted in the 204th "Litteraturbrief." Cf. also " Hamburgische Dramaturgie," Iorst-ro4th "Stück," pp. 209-210; LachmannMuncker edition, Vol. X.

" Hamburgische Dramaturgie." Cf. l.c. p. 90, 96th "Stück."

"Cf. ibid., 6gth "Stück." Vol. X, p. 76. 
to dispense with criticism because it, too, crushes genius. $\mathrm{He}$ is not a poet, he claims; what rank he has as such, he owes to criticism. "Therefore," he continues, "I always have felt disgraced or angry when I read or heard anything to the disadvantage of criticism. Criticism is said to suffocate genius, ${ }^{1}$ and I flattered myself that I had learned something from criticism, something that approaches genius closely. I am a lame man whom no lampoon against the crutch can possibly edify." 2 $\mathrm{He}$ admits that the crutch can help a lame man from one place to the other; but still, he contends, it can not make him a runner; and so criticism has its limits in literature. ${ }^{3}$

Thus Lessing, in his "Hamburgische Dramaturgie," is far in advance of the growing Geniekult. Having seen the dangers of the extreme tendencies of the unbridled enthusiasm for original genius, he warns against the absolute overthrow of rules. While placing genius above rules, he nevertheless seeks to restrain lawless genius, and thus he becomes the prophet of the coming reaction against the Storm and Stress, clinging, as he does, to the position to which the unbridled enthusiasm of the Storm and Stress had to return, before a literature could be created worthy of the first rank.

After the "Hamburgische Dramaturgie" Lessing lost interest in the stage, and so the Storm and Stress, having no guide for its caprices, had to run the gamut of extravagances and learn by experience what it otherwise could have avoided with Lessing's fatherly, mature, and safe criticism.

\section{Johann Georg Hamann (I730-i788)}

Hamann's residence in London, altho in an uncertain commercial capacity, prepared the way for his future English

\footnotetext{
1 This had been asserted in the 204th "Litteraturbrief." Cf. also "Hamburgische Dramaturgie," rorst-ro4th “Stück," pp. 209-210; LachmannMuncker edition, Vol. X.

${ }^{2}$ Cf. Young: "Rules, like crutches, are a needful aid to the lame, tho an impediment to the strong." "Complete Works," edited by Doran. Vol. II, p. 557 .

3 "Hamburgische Dramaturgie." ror-ro4th "Stuck." Cf., l.c. Vol. X, pp. 209-2I0.

4 From April I8, I757, to June, I758, in secret commission for the business house of his friend Berens of Riga.
} 
studies and his consequent deep interest in English writers. His unsettled and for a time wayward life during that period naturally did not lead him into the circle of the author of the "Night Thoughts," and it was not until his return to the Christian precepts of his early home training that Young could interest him deeply. He knew some English before his visit to London and he had become acquainted with the "Night Thoughts" in the early fifties, as is proved by his eulogy of his deceased mother, which bears Young's name and a verse from the "Night Thoughts" on the title-page, and shows clearly the influence of that poem."

Hamann regarded his spiritual and moral rescue as a special dispensation of providence, and, having returned to the straight and narrow path, he became a religious zealot and an ardent disciple of Young's religious muse, so that he wrote later in life: "Recently I had occasion to run thru Young quite unexpectedly; then it seemed to me as if all my hypotheses had been a mere afterbirth of his 'Night Thoughts,' and as if all my whims had been impregnated with his metaphors. So uncertain am I of myself, that I even doubt whether my thoughts have not been supposititious changelings. At all events, Young was at that time newer and fresher in my memory than now. Can it be that I did not even notice my own thefts? I have never been ashamed to confess the truth." 2

Three years after his return from London we find him reading "his Englishmen" every evening for pastime ${ }^{3}$ and edification." About three years later he continues these studies with several good friends, ${ }^{5}$ and ten years after that his friend Professor Kreuzfeld learns English from him. He takes special delight in his ability to read and appreciate his favorite English writers in the original, because, as he says, "The Swiss give us nothing but the shells of the English and depict nothing but the surface." 3

1 "Denkmal." Cf. infra, p. 96.

2 Letter to Herder, Königsberg, Jan. I7, r769. Cf. "Hamann's Schriften. Herausgegeben von Friedrich Roth." Berlin, r821-1843. Vol. III, p. 393.

${ }^{3}$ Letter to J. G. Lindner, Königsberg, April rr, r76r. Cf. ibid., p. 76.

- Letter to G. E. Lindner, Königsberg, April 29, r76r. Cf. ibid., p. 79.

5 Letter to J. G. Lindner, Königsberg, May 2, I764. Cf. ibid., p. 224 . 
So much for his intense interest in English literature in general. As we have seen, it was thru the medium of the "Night Thoughts," the work that had made Young famous in Germany, that Hamann, in common with the rest of his fellowcountrymen, became so deeply interested in Young and, therefore, received so eagerly the "Conjectures on Original Composition" immediately upon their appearance. But in Hamann's case there was a more direct bond, the kinship of letters; he recognized in the aged bard of trials and tribulations, in the revered preacher of Christian maxims, a second and mutual tie; namely, their common interest in the vital question of genius and authorship.

He says of himself, "You know that in case of necessity I like to be my own critic." ${ }^{1}$ And, as a matter of fact, few authors have expressed themselves more freely and more abundantly on their own authorship than Hamann. As early as 1758, before he had made his début in the world of letters, ${ }^{2}$ he says, writing of his conception of style and poetry, "I gained ... my taste for the latter too late in life and, therefore, find it difficult to collect my thoughts and to express them fluently both in speaking and in writing." 3 Elsewhere he speaks of his obscurity, his laborious (dromedarisch) pen, and of his style as mimical and spermologisch. His "Sokratische Denkwürdigkeiten" are couched "in the mystical language of a sophist," and he thinks he has treated Socrates "in a Socratic manner." " He writes by the sweat of his brow, ${ }^{5}$ and protests thruout his life that he does not want to become an author. "My folly always pictured to me a sort of pride and sublime vanity, not to study for bread, but according to my inclination, for pastime and out of love for the sciences per se, on the ground that it were better to be a martyr than a daylaborer and hireling of the muses." 6 If the public, a wounded

${ }^{1}$ Letter to Baron von W., Riga, Sept. 22, I758. Cf. "Schriften," Vol. I, p. 307 .

${ }^{2}$ He himself considered the "Sokratische Denkwürdigkeiten" as the beginning of his authorship. The work appeared early in the year I 760 .

3 "Lebenslauf," in "Schriften," Vol. I, p. I 57.

4 "Sokratische Denkwürdigkeiten," in "Schriften," Vol. II, p. 7; also p. II.

${ }^{5}$ Letter to his brother, May, I760. Cf." "Schriften," Vol. III, p. 22.

6 "Lebenslauf," in "Schriften," Vol. I, p. I72; also p. 362. 
officer, ${ }^{1}$ and a good friend wish to be amused in the same manner, he will never succeed as an author. ${ }^{2}$ He merely wants to serve his years as pupil honestly ${ }^{3}$ he hates from the bottom of his heart the office of both author and critic." And still he drifts involuntarily into authorship, gently resisting and yet quietly acquiescing, so that he calls out in despair, "Dost thou still cling to thy weakness, dear heart, of becoming a public author in large quarto!" 5 And as he later in life reviews his career, he sees that he has acquired a style that is neither pleasing to himself nor natural. ${ }^{6}$ His entire works amount to nothing but pitiful criticism, all his scribblings are nothing but black on white, mere text, without notes to make them intelligible, of mere ephemeral importance." "My authorship is folly. ...." 8 And as a final judgment he seems to see nothing but failure in his literary activity. ${ }^{8}$

Still posterity has judged Hamann an original genius, and he, in spite of his protests against a literary career, toyed with the idea of being an original. "If the vanity of becoming a model should tempt me, I should be the first to laugh at the idea. Nothing shall frighten me from the duty of being an original. An original frightens away imitators and produces models." 10 Young says, too, "The pen of an original writer ... out of a barren waste calls a blooming spring." "1

Of authorship in general he also has much to say. What a task it is, and how can one possibly find ambition, vanity, or

' Possibly an allusion to Lessing who, in the introduction to the Litteraturbriefe, says they were intended for the entertainment of a wounded officer.

${ }^{2}$ Letter to J. G. Lindner, Trutenau, July 20, I759. Cf. "Schriften," Vol. I, p. 423 .

3 Letter to the same, March 29, I763. Cf. ibid., p. 193.

4 Letter to the same, Feb. 22, I764. Cf. ibid., p. 217.

s "Selbstgespräch eines Autors" (I 773), in "Schriften," Vol. IV, p. 75.

'Letter to J. C. Häfeli, Königsberg, July 2, x 780. Cf. "Schriften," Vol. VI, pp. $15^{1-1} 5^{2}$.

${ }^{7}$ Letter to F. Bucholtz, Königsberg, Sept. 6, r786. Cf. "Schriften," Vol. VII, p. 340.

${ }^{8}$ Letter to Herder, Königsberg, Jan. 28, 1787 . Cf. ibid., p. 350.

- Cf. "Schriften," Vol. VIII, x, p. 375 .

${ }^{10}$ Letter to J. G. Lindner, Königsberg, March 29, 1763. Cf. "Schriften," Vol. III, p. I9I.

11 "The Complete Works, Poetry and Prose, of the Rev. Edward Young, LL.D.," etc., edited by John Doran, LL.D. London, 1854 , Vol. II, p. 55 I. 
pleasure in it $;^{1}$ for an author is exposed to the severest tests of self-denial." Young says, too, "Wit ... should sacrifice its most darling offspring to the sacred interests of virtue and the real service of mankind." 3 "One can at all events be a human being," says Hamann, "without necessarily being an author. But whoever expects good friends to imagine an author who is not a human being, is more inclined toward poetical than philosophical abstractions." " "The question involved in the criticism of a masterpiece is not at all, has it faults, but where do these faults lie and what use is made of them? Every intelligent author knows his faults in advance, but he also knows how to assign to them their proper places, where they will either blend or produce a contrast like shadows in a painting." 5 This sounds like an echo of what Young says of Shakspere's faults as compared with the ancients, "Not the fewness of their faults, but the number and brightness of their beauties," is what we admire in the ancients. ${ }^{\circ}$

The subjective view that Hamann takes of style seems to express the entire doctrine of individualism as found in Young. "What others call style, is for me soul or ability to judge and to digest." ?

Young remarks, "Thucydides is said to have formed his style on Pindar;" 8 likewise Hamann: "Man nennt ihn den Pindar der Geschichtschreiber."

One of Hamann's favorite diversions was to compare translations. ${ }^{10}$ Poetical translations were not to his taste, ${ }^{11}$ and he

${ }^{1}$ Letter to his brother, Königsberg, Jan. 2, I769. Cf. "Schriften," Vol. III, p. 3 .

"Letter to J. G. Lindner, Königsberg, May 5, r76r. Cf. "Schriften," ibid., p. 83 .

3 "Complete Works," Vol. II, p. 550.

4 "Aesthetica in Nuce," in "Schriften," Vol. II, p. 267.

5 Letter to J. G. Lindner, Königsberg, Aug. 23, I76r. Cf. "Schriften," Vol. III, p. 97.

- "Complete Works," Vol. II, p. 573.

7 Letter to Herder, Königsberg, Oct. 13, I777. Cf. "Schriften," Vol. V, p. 257.

8 "Complete Works," Vol. II, p. 579.

- "Schriften," Vol. II, p. 263.

10 Letter to Scheffner, Königsberg, Dec. 9, 1784. Cf. "Schriften," Vol. VII, p. 184 .

11 Letter to the same, July I, I785. Cf. ibid., p. 254; likewise p. 256. 
preferred an exact to a merely noble translation.' 'Like Young, he is opposed to an excessive amount of translation, for it is likely to make of a language a net that catches and receives good and bad fish of all kinds. ${ }^{2}$

To comprehend fully the intellectual kinship of the two writers, one must compare in detail their utterances on the two main themes of the "Conjectures on Original Composition," viz., Genius and Originality. Almost every thought expressed by Hamann on these subjects has its model in Young.

Hamann says, genius does not depend upon diligence, ${ }^{3}$ and further, "The honorable title of language master and polyhistor is not a sine qua non for him who has the good fortune to be endowed with their genius." " Genius, then, is something superior to learning and diligence; it is, as he says elsewhere of original works of art, of a divine quality. Young, we remember, calls genius the "master-workman," and says it "is the power of accomplishing great things without the means generally reputed necessary to that end," "a magician ... that raises his structure by means invisible. ... Hence genius has ever been supposed to partake of something divine." It is the god within us. ${ }^{5}$

Hamann says of the relation of genius to rules: "... wer keine Ausnahme macht, kann kein Meisterstück liefern; weil Regeln vestalische Jungfrauen sind, durch die Rom vermittelst Ausnahmen bevölkert werden musste . . . wer ein Schöpfer $\mathrm{zu}$ werden wünscht, ... verhülle sich und seine Muse! Verhüllt und entgürtet werfen Autor und seine Muse die Knochen ihrer Mutter hinter sich. Vor waren sie Regeln, die kein Säugling verdauen kann, und Stein des Anstosses den alten Ahnen; nun sind sie Meisterstücke, die leben, göttliche Werke eurer Hände, die euch nachfolgen werden, weil sie Füsse haben." ${ }^{6}$ Likewise: "Ein Engel fuhr herab zu seiner Zeit und bewegte den Teich Bethesda, in dessen fünf Hallen viel Kranke, Blinde,

\footnotetext{
1 Letter to J. G. Lindner, Aug. 8, r 759. Cf. "Schriften," Vol. I, p. 466.

2 "Schriften," Vol. II, p. I26.

3 Cf. ibid., Vol. IV, p. 325.

'Cf. ibid., Vol. II, p. r24.

s "Complete Works," Vol. II, p. 556; also p. 557.

- "Schriften," Vol. II, pp. 405 f.
} 
Lahme, Dürre lagen und warteten, wenn sich das Wasser bewegte. - Eben so muss ein Genie sich herablassen Regeln zu erschüttern; sonst bleiben sie Wasser; und - man muss der erste seyn hereinzusteigen, nachdem das Wasser bewegt wird, wenn man die Wirkung und Kraft der Regeln selbst erleben will." 1 And: "Hören Sie unterdessen, wie erwecklich der Oberpriester und Afterminos zu Lampadouse in seiner Bürgergemeinde deklamirt: ' $O$ ihr Herolde allgemeiner Regeln! wie wenig versteht ihr die Kunst, und wie wenig besitzt ihr von dem Genie, das die Muster hervorgebracht hat, auf welche ihr sie baut, und das sie übertreten kann, so oft es ihm beliebt!"' 1

Young likewise says, "Learning, destitute of this superior aid (of genius), is proud of what has cost it much pains, is a great lover of rules and boaster of famed examples ... unprescribed beauties and unexampled excellence, which are characteristic of genius, lie without the pale of learning's authorities and laws ... for rules are a needful aid to the lame, though an impediment to the strong." Masterpieces, i.e. originals are exceedingly rare, because they must be something new; and no matter in what form they appear, they engross us, and if they add admiration to surprise, we are at the writer's mercy." Hamann says, "A gifted author must either know how to exceed his readers' expectations, or how to win his readers." 3 Many a great man, says Young, has been lost to himself and the public, purely because great ones were before him. ${ }^{4}$

In his discussion of Proverbs ro, I9, Hamann says that brevity is a characteristic of genius, all superfluity is the sin of erudition. The most inane works, those most lacking in taste and faultiest need fine choice of language to hide their defects. ${ }^{5}$ Likewise Young : "As riches are the most needed where there is least virtue, so learning where there is least genius ...

\footnotetext{
1 "Schriften," Vol. II, p. 430; also p. 43I.

2 "Complete Works," Vol. II, pp. 556-557; also pp. 552, 553.

${ }^{3}$ Letter to J. G. Lindner, March 4, I762. Cf. "Schriften," Vol. III, p. I33.

4 "Complete Works," Vol. II, p. 560.

5 " Schriften," Vol. I, p. I03. Cf. Lessing, supra, p. 26.
} 
genius without learning can give renown. ... To neglect of learning genius sometimes owes its greater glory." 1

Similarly discussing the Schuldrama, Hamann says, "Without self-denial no work of genius is possible, and without eschewing the best notes, rules, and laws, no Schuldrama or prototype thereof." 2 Young, "Genius can set us right in composition without the rules of the learned ... singly, . . . (it) can sometimes make us great." ${ }^{3}$ Again Hamann, "Alle grosse Genies scheinen einigermassen jenem fremden Volke ähnlich zu seyn, von dem Mose und die Propheten geweissagt, dass es ' wie ein Adler fliegt und ein Volk von tiefer Sprache ist, die man nicht vernehmen kann und von lächerlicher Zunge, die man nicht versteht." " This is a common figure in Young. $\mathrm{He}$ speaks of the original genius as carrying us away with him "on the strong wing of his imagination," 5 he cites Pindar as calling himself the eagle flying above common understanding, and sets the paradox, "Genius often deserves most to be praised when it is most sure to be condemned, that is, when its excellence, from mounting high, to weak eyes is quite out of sight."

Both Hamann and Young take the same specific examples to prove these principles, i.e. among the ancients Homer, who cast rules aside; among the moderns Shakspere. Young says, if Shakspere had read more, he might have thought less. He knew two books, that of nature and that of man. ${ }^{7}$ Hamann: "Was ersetzt bey Homer die Unwissenheit der Kunstregeln, die ein Aristoteles nach ihm erdacht, und was bey einem Shakspere die Unwissenheit oder Uebertretung jener kritischen Gesetze? Das Genie ist die einmüthige Antwort." $8 \mathrm{He}$ cites further the case of the Apostle Paul. "Festus, too, was of the opinion that Paul's extensive reading confused him, and attributed his fanatical giddiness to books," ${ }^{\circ}$ and even asserts, "The less one has learned himself, the more skilled one is.

1 "Complete Works," Vol. II, p. 557.

2 "Schriften," Vol. II, p. 432.

3 "Complete Works," Vol. II, p. I84.

4 "Schriften," Vol. IV, p. 364 .

6 "Complete Works," Vol. II, p. $55^{2}$.
${ }^{6}$ Cf. ibid., p. 557.

7 Cf. ibid., p. 574 .

8 "Schriften," Vol. II, p. $3^{8 .}$

${ }^{\circ}$ Cf. ibid., p. 92. 
to teach others." 1 "Socrates," he says, "could well, indeed, be unknowing; he had a genius." 2

Hamann would not have us infer that he considers genius, in and of itself, a sufficient guide, even to the neglect of learning. "Is, however, the folly of genius rich enough to replace the wisdom, which thru the connection of universal truths is obvious to the senses? There's the rub." 3 Young, too, after expounding the great advantages of genius, "put in a caveat against the too great indulgence of genius," viz., "He who disregards learning shows that he wants its aid." 4 And, beware those "who set up genius, and often mere fancied genius, not only above human learning, but divine truth." If geniuses are wise, let them not neglect the cultivation and produce of their possessions. ${ }^{5}$

Young's division of imitations into two kinds, "one of nature, one of authors," 6 is also found in Hamann: "Natur und Schrift also sind die Materialien des schönen, schaffenden, nachahmenden Geistes." 7 "Poesie," he says further, "ist die Nachahmung der schönen Natur," 8 and yet he does not advise us to imitate everything in nature, but only that which will extend the republic of letters, as Young would say, along the more beautiful, healthy lines, and which will be of real service to mankind." "In der Natur ist manches unrein und gemein für den Nachahmer - auch alles was möglich ist, lasst euch nicht gelüsten!" 10

Like Young before him, Hamann complains of the lack of original production, ${ }^{11}$ and like Young, he hates the prevailing method of servile imitation. "Es thut mir immer wehe, den lächerlichen Nachahmungs-Geist, der immer die schwächsten Seiten guter Köpfe verfolgt, ihnen mit seiner Bewunderung schädlicher und gefährlicher zu sehen, als alle Furien des Neides, oder ungerechter Critik." 12

\footnotetext{
1 "Schriften," Vol. II, pp. 2 I 7 ff. $\quad 7$ "Schriften," Vol. II, pp. 292 ff.

${ }^{2}$ Cf. ibid., p. $3^{8 .}$

${ }^{3}$ Cf. ibid., p. 98.

4 "Complete Works," Vol. II, p. 559.

${ }^{5}$ Cf. ibid., p. 560.

${ }^{\circ}$ Cf. ibid., p. 55 I.

${ }^{8}$ Cf. ibid., p. 280.

" "Complete Works," Vol. II, pp. 549$55^{\circ}$.

10 "Schriften," Vol. II, p. I97.

${ }^{11}$ Cf. ibid., p. 402.

${ }^{12}$ Letter to Scheffner, Königsberg, Sep. I8, I785. Cf. "Schriften," Vol. VII, p. 287 .
} 
Hamann says, man is "among all animals the greatest pantomime." 1 Young, too, speaks of the "meddling ape imitation" that is inherent within us. ${ }^{2}$ Similar to Young's distinction between servile imitation and productive imitation of the spirit of one's predecessors, Hamann says, "Nachahmen und Nachäffen (ist) nicht einerley." 3 Hamann scores the underrating of oneself and one's own powers, in the following manner: "Der eines andern Vernunft mehr glaubt als seiner eignen, hört auf ein Mensch zu seyn, und hat den ersten Rang unter dem servum pecus ${ }^{4}$ der Nachahmer. Auch das grösste menschliche Genie sollte uns zu schlecht dazu seyn." 5 This is Young's maxim. "Such meanness of mind, such prostration of our own powers (imitation of others), proceeds from too great admiration of others. Admiration has generally a degree of two very bad ingredients in it, - of ignorance, and of fear." To avoid this, and to remind and encourage us to look within ourselves, lest the mine of genius hidden there lie undiscovered and "we go a-begging with gold in our purse," Young borrows two rules from ethics: "Know thyself," "Reverence thyself." These, strange to say, are found in Hamann too. The second is voiced by him in the above-quoted passage, whereas the first is expressed directly, when he cites in another connection the inscription above the door of the famous temple at Delphos, "Erkenne dich Selbst!" ?

When Hamann complains, "If they intend to make it as. difficult for us to be originals as to be copies, what else do they intend but to change us into mules?" 8 (i.e. if the choice of material and method is to be limited); and when he says further, "Whoever wishes to deprive the fine arts of caprice and imagination, is a quack ... makes an attack upon their honor and life like a cut-throat, . . ." ${ }^{9}$ he is merely

1. "Schriften," Vol. IV, p. 42. In discussing the beginnings of a child's training, he says: "Weil wir alle zum Nachahmen geboren sind, besonders die Natur nachzuahmen." Cf. "Schriften," Vol. I, p. I62.

2 "Complete Works," Vol. II, p. 56r.

3 Letter to his brother, Königsberg, Feb. I2, I760. Cf. "Schriften," Vol. I, p. II.

- "Complete Works," Vol. II, p. 565.

"An expression taken from Horace. 7 "Schriften," Vol. II, p. 30.

[ Letter to Kant, Königsberg, July $27,{ }^{8}$ Cf. ibid., p. I97.

1759. Cf. "Schriften," Vol. I, p. 438. 'Cf. ibid., pp. 40I-402. 
taking up ardently the cause of the emancipation of genius, the rights of the individual and the promulgation of originality as acclaimed by Young.

Hamann's attitude toward the ancients is very similar to Young's. In speaking of an edition of Euripides, he calls it good enough for him, it detains him less in his work, "since," as he says, "I follow up only the spirit of the ancients, and the genius of the Greek language is of more importance to me than its grammar." 1 This is exactly what Young advises, viz., that in reading the ancients we should pursue not their material but their spirit and taste. ${ }^{2}$ This Hamann expresses very decidedly and with great emphasis, when he narrows it down to the specific examples of Bodmer and Klopstock. They have imitated Homer only in detail. "Homer," he says, "will always remain the only epic poet for my taste. . . . To feel Homer is not within the power of every one: aye, to understand Homer ... must one not do that, if one wishes to imitate him? To imitate is in the fine arts to surpass." 3 . "Bodmer and Klopstock both studied Homer, but did not know how to imitate him except in details." 4

Young, as is to be expected of a theologian, goes beyond the Greek and Latin classics in his discussion and cites the sources of wisdom as revealed in the Scriptures. ${ }^{5}$ He says the Bible

1 "Schriften," Vol. II, p. 2 I3.

2 "Complete Works," Vol. II, p. 555.

${ }^{3}$ Letter to Lindner, Königsberg, Aug. 28, r76r. Cf. "Schriften," Vol. III, p. Io9.

This is the finest expression found in Hamann of the correct method and purpose of imitation, i.e. make full use of one's predecessors and of one's own genius, and thus surpass one's models. It is the very essence of Young's "Conjectures." It is interesting to note in this connection, that Hamann insists that one must read the classics of all nations, "mit und in dem Geist ihrer Verfasser." ("Schriften," Vol. IV, p. 26r.) Further, one should in reading use his imagination to try to have the same feelings that the author he is reading had when he wrote. ("Schriften," Vol. I, p. 54.) And finally: "Zum Urtheilen gehört dass man jeden nach seinen Grundsätzen prüft und sich selbst an die Stelle des Autors setzen kann." ("Schriften," Vol. III, p. I I6.) These thoughts had already been expressed by Pope, cf. supra, p. I3. Cf. further, Gerstenberg, supra, pp. 23, 24. Cf. also Herder, infra, p. 42.

${ }^{4}$ Letter to his brother, Königsberg, Jan. 9, r760. Cf. ibid., p. 6.

5 This phase of the discussion was introduced by the appearance, in 1753 , of Robert Lowth's "De Sacra Poesi Hebraeorum." 
is the only book "that can justify our implicit acquiescence in it." 1 So Hamann : "Gerade, als wenn unser Lernen ein blosses Erinnern wäre, weist man uns immer auf die Denkmale der Alten, den Geist durch das Gedächtniss zu bilden. Warum bleibt man aber bey den durchlöcherten Brunnen der Griechen stehen, und verlässt die lebendigsten Quellen des Alterthumes? Wir Wissen vielleicht selbst nicht recht, was wir in den Griechen und Römern bis zur Abgötterey bewundern. . . . Gleich einem Manne, der sein lieblich Angesicht im Spiegel beschaut, nachdem er sich beschaut hat, von Stund an davon geht und vergisst, wie er gestaltet war; eben so gehen wir mit den Alten um." 2

Hamann admits that the ancients have made it hard for us to be originals, but he says, "I am not, however, as bad as Donatus who wished all sorts of misfortune to the ancients, who take the very word out of our mouths." 3

When Hamann says of Homer, "Even he is said to have been a fortunate compiler, according to the opinion of the best critics," 4 he may refer to the discussion of the authorship of Homer or he may even be echoing Young's theory of accidental originals. ${ }^{5}$

Hamann did not merely preach Young's ideas; he strove to follow them out in his own original essays. One of the clearest, avowed cases of this is found in the postscript to his complaint on churçh music. "Here he cites Young's paradox in the following manner: "Young giebt ... das Räthsel auf, die Alten also nachzuahmen, dass wir uns von ihrer Aehnlichkeit, je mehr je besser, entfernen," and then he goes on to say that he has written this "Klagegedicht" in this "paradoxical" imitation of the "Epitre à Uranie" and the "Sendschreiben eines Materialisten an Doris." 7

1 "Complete Works," Vol. II, p. $55^{8}$.

2 "Schriften," Vol. II, pp. 288-289.

3 Letter to Lindner, Königsberg, May 7, I762. Cf. "Schriften," Vol. III, pp. $x^{2}$ ff.

4 Letter to his brother, Königsberg, January, 1760. Cf. ibid., p. Io.

" "Complete Works," Vol. II, p. 553.

- "Klagegedicht in Gestalt eines Sendschreibens über die Kirchenmusik; an ein geistreiches Frauenzimmer ausser Landes" (I762). Cf. "Schriften," Vol. II, pp. 16r-r 72 .

7 "Nachricht für Leser, die Verstand haben, denen folglich mit Verstand gedient werden muss." Cf. "Schriften," Vol. II, pp. I73-I74. 
Finally, the best example of Young's influence upon Hamann in point of choice of material, style, and purpose is found in the articles entitled "Schriftsteller und Kunstrichter" 1 and "Leser und Kunstrichter." 2 Here we find an ardent plea for taste in reading, judgment in criticising, and originality in writing one loud cry for individualism, pervaded with Young's spirit. It is the clearest and most direct production of Hamann's genius.

Hamann, then, in his views on originality and individualism, owes the greater part of his material to Young. His own opinion that nearly all his ideas were taken from the "Night Thoughts" would read more correctly if he had said they were taken from the "Conjectures"; for upon examination there are few passages that can be said to come unmistakably from the "Night Thoughts." Both writers treated Biblical themes and they therefore had many points in common, from common sources.

Hamann stands entirely upon the plane of the "Conjectures"; he theorizes and suggests modes of procedure, but progresses no further, except for a few slight attempts to exemplify his ideas. His work is in general terms, and it needed Herder to take up these doctrines, to apply them to German literary conditions, and thus to pass from Hamann the prophet of originality to Herder the prophet, teacher, and promoter of a national, original literature.

\section{Johann Gottfried Herder (1744-1803)}

If in Hamann the direct influence of the "Conjectures" is so unmistakable and abundant, it would be a surprise not to find a similar influence of Young's doctrine of original genius and individualism in Herder's works; for Herder, as the friend and disciple of the Magus im Norden, thus drew inspiration from a double source. And if it is not always possible to determine to which source the influence is to be traced, it really matters little; for both proclaim the emancipation of genius and the supremacy of individualism; both issue from the same fountain 1 "Schriften," Vol. II, pp. 377-394. I762. $\quad{ }^{2}$ Cf. ibid., pp. 395-4I2. I762. 
head and feed the same current in eighteenth-century critical thought.

Be that as it may, Herder's works furnish ample proof of his intimate acquaintance with the "Conjectures" and of his admiration for their author. Altho only a youth of sixteen when the "Conjectures" appeared in Germany, Herder had in all probability already become acquainted with the "Night Thoughts"; for it would be strange if so popular a work had not found its way into the hands of this insatiable devourer of books. At least, Herder's reviews and criticisms, as well as his longer works, often cite the "Night Thoughts" in a manner that suggests a thoro knowledge and deep appreciation of them. He translates from them, uses them as examples, and publishes parts of a translation by another. ${ }^{1}$

The "Conjectures" occupied him early, at all events, whether he was led to them thru the "Night Thoughts" or not; and as if in preparation for his life's work of criticism and the rejuvenation of German literature, along the lines laid down by Young, Herder made extensive extracts from the "Conjectures" in his note book. ${ }^{2}$ It is not surprising, therefore, to find him breaking a lance for his champion soon after in a cutting review of Rector Rambach, who, either wilfully or ignorantly misunderstanding and misinterpreting Young's attitude, published a Schulprogramm entitled "Schreiben über die Frage: ob das Lesen der Alten an dem Mangel der Original-Scribenten Schuld sey." In this Rambach takes issue with Young's claims that the reading of the ancients and admiration for them engrosses and intimidates us and thus limits our own productiveness. Herder writes in criticism: "Great Young has suffered the same fate before, of having some of his bold utterances severed from the rest, dissected and discussed, corroborated or refuted, according to the critics' caprice. When a genius mounts to sublime heights in his original thoughts, the spirits on the plain below lose sight of him or see him in dwarfed proportions upon his pinnacle. ... He (Young) often developed

1 Cf. infra, p. 108.

2 "Herder nach seinem Leben und seinen Werken dargestellt von R. Haym." Berlin, 1877-r885. Vol. I, p. I49. 
the chain of his bold thoughts to a degree that seems a paradox to us weaker intellects." 1

This is indeed sufficiently ardent admiration to show Herder's attitude toward the author of the "Conjectures," and it is interesting to note that in extolling his genius Herder uses Young's own words on the flights of original genius, as found in his second paradox: "Genius often then deserves most to be praised, when it is most sure to be condemned; that is, when its excellence, from mounting high, to weak eyes is quite out of sight." 2

Herder disapproves entirely of Rambach's attitude and says, whoever is inclined to be on Young's side at the beginning of the article, will surely be so at the end. Further, he says, to do justice to a genius like Young is hardly within the scope of a mere Schulprogramm. Later, discussing the reading and imitation of the ancients, Herder draws from the "Conjectures" and in a footnote again cites Rambach's formidable article against "good" Young."

In the second of the "Kritische Wälder" Herder says of Young's eulogy on Addison, "I honor the late Young in this testimonial of him." " Likewise, Herder's criticism of Swift makes reference to the "Conjectures," but this time at variance with them; for in the fourth of the "Kritische Wälder" he remarks, "Who would join with the immortal night-watchman ${ }^{5}$ Young, when he complains because Swift's Houyhnhnms are not pious hermits? Let each one be what he is :" 8 thus applying Young's principle of appreciation to Swift better than Young himself. Indeed, even as late as I8or, Herder returns

${ }^{1}$ The review appeared in the Königsbergsche Gelehrte und Politische Zeitungen. Cf. "Herders Sämmtliche Werke. Herausgegeben von Bernhard Suphan." Berlin, I877 to date. Vol. I, pp. I2I-I23. For Rambach's article, cf. infra, Bibliography, $\mathrm{I} 765$; also supra, p. I7.

2 "The Complete Works, Poetry and Prose, of the Rev. Edward Young, LL.D.," etc., by John Doran, LL.D. London, r854. Vol. II, p. 557.

3 "Ueber die neuere Deutsche Litteratur. Fragmente," etc. "Dritte Sammlung." Riga, i 767. Cf. "Werke," Vol. I, p. 383 .

4 "Werke," Vol. III, p. 304; also Young's "Complete Works," Vol. II, pp. $580-584$.

"Nachtwächter"; in the first edition "Nachtwacher."

" "Werke," Vol. IV, p. I90; also Young's "Complete Works," Vol. II, pp. 567-568. 
to Young's tirade against Swift and calls it insipid and untrue. ${ }^{1}$

In his work on Hebrew Poetry, Herder also applies Young's first paradox to the imitation of the Psalms of David, in the following words: "And here too Young's rule should be applied, that one often resembles the ancients most, when one seems to depart furthest from them." 2 And it is very significant that even as late as 1800 , Herder remembers and applies this paradox. In the introduction to the "Kalligone," after discussing the case of a young man who tried to overcome certain peculiarities that he had taken from his old professor, and who never felt freer and further from the latter's system than when he modestly honored his wisdom and sagacity, Herder says, "Young gives similar advice: to imitate the ancients in spirit, by departing from them," and then continues with the following indorsement: "Let whoever will follow this advice; he will thus feel himself free, rejuvenated; he will seem master of his soul, of his pen and tongue." 3

And so again at the close of his career we find a watchword from the work which he so carefully studied ${ }^{4}$ in preparation for his journey thru the labyrinthine paths of a life of literary criticism. Young was fresh in Herder's mind from the beginning of his literary career to its very close; and a careful study of his works proves still further the extent of his indebtedness to the "Conjectures."

Beginning with the theme of imitation, we find that Herder did some of his best work in this direction, applying in a practical way to German literature the principles of Young, and thus passing beyond the realm of speculative thought into the arena of a noble, patriotic cause. ${ }^{5}$ In 1764 , he had already said he was

1 "Adrastea," II, rg. "Jonathan Swift. Gegenseite." Cf. "Werke," Vol. XXIII, p. 187; also Young's "Complete Works," Vol. II, p. 567.

2 "Vom Geist der Ebräischen Poesie," Zweiter Theil. I783. X," Charactere der Psalmendichter." Cf. "Werke," Vol. XII, p. 235; also Young's "Complete Works," Vol. II, p. 555.

3 "Werke," Vol. XXII, pp. I2-r 3.

4 Cf. supra, p. $4 \mathrm{r}$.

"Herder sums up the conditions that he is trying to relieve thus: "We are working in Germany as if in the confusion of Babel; sects of taste, parties of poetry, schools of philosophy, are contending against each other; no capital and 
glad the Middle Ages were past, when the Germans freed themselves from barbarism only to neglect their own language and to become imitators of the ancients. ${ }^{1}$ And now, three years later, he exerts his forces to carrying on this good work of emancipation a step further. Since German national pride, on the one hand, decided that Germany must not be inferior to any other nation whatsoever in belles lettres; since, on the other hand, the imitation craze to transplant to half-German soil all that is Oriental, Greek, or British has subsided; and since critics have commenced to gain a comprehensive view of the present state of German letters, no cry has been louder or more frequent, Herder says, than the complaint over the lack of originals, of genius, of inventors. The Litteraturbriefe sought to point out the way to supply this need. Mere fault-finding, repeated complaints, and everlasting precepts will not do it, however; nor can the prevailing attempts to analyze and define genius, original power, and invention succeed in arousing genius. Why does Young's treatise on original works fill the Germans with an ardor that is not felt in reading these analyses of genius, Herder exclaims. Because Young's spirit is inherent in it, and this spirit speaks from heart to heart, from genius to genius, and is transmitted on and on like an electric spark. ${ }^{2}$ Such an example, Herder continues, requires observation; it is an example in and of itself to be followed; it is the most effective means of dissuading fools from their desire to become original geniuses. Such great examples alone can change the spirit of a nation; but, since it is dangerous to bring down this electric spark from heaven like a second Prometheus, and because it is more difficult to be an artist than a sophist in art, the safest path is to observe the works of others, to encourage and inspire thru them.

no common interest; no great, universal promoter and universal law-giving genius." Cf. "Werke," Vol. I, p. I4I. And for this purpose he encourages originality and deprecates imitation; for, he says, "An original writer, with few exceptions, is always a national author." Cf. "Werke," Vol. I, p. 402.

1 "Ueber den Fleiss in mehreren gelehrten Sprachen," Gelehrte Beyträge zu den Rigischen Anzeigen aufs Jahr I 764. XXIV. Stück. Cf. "Werke," Vol. I, pp. 6-7.

2 "Ueber die neuere Deutsche Litteratur. Zwote Sammlung von Fragmenten." I767. Einleitung. Cf. "Werke," Vol. I, pp. 254-257. 
And so Herder carries out this comparison of modern German imitators of Oriental, i.e. Hebrew, and especially of Greek writers in detail, defining the restrictions of such imitations and relative faults and merits of each.

In Chapter I, "Von den Deutsch-Orientalischen Dichtern," Herder shows how German poets think they become originals by borrowing customs and taste from the Hebrews. Theif pictures, altho not new, are not only strange pictures, sentiments, and inventions; but, further, they are incongruous; conditions are incompatible, and the only way we can copy these Orientals is to depict our own nature faithfully as they depicted theirs, true to itself. "We are not prevented by poverty, but by inconvenience and indolence, from using our treasures and preferring, as Cæsar says, to be pauperes nostro in aere."

Thus Herder applied in this whole discussion, step by step, the principles laid down by Young, and the results are precisely those of the "Conjectures." Young insists, we remember, that we must not build with the materials of the ancients, but in their spirit and taste, i.e. study nature as we find it revealed about us, and depict it in the natural manner of the ancients. Young also insists that it is not poverty, but ignorance and sloth, that prevents us from cultivating the treasures within ourselves, and he likewise quotes from Horace, Cæsar's words, Meo sum pauper in aere. ${ }^{2}$

The second chapter continues this discussion in a similar but less pointed manner. In the third chapter, Herder takes up the subject of the homogeneous saga material that is inherent in the very nature of every people, and points out the fact that this national material has always been the magic source for poets of all times and nations. He calls attention to the fact that such materials exist on Aryan soil and urges his fellow-countrymen to cultivate their own resources, promising them a rich and abundant harvest.

Thus Herder again gives to Young's precepts a national bearing; he appeals to his fellow-countrymen, not as individual writers, but as patriotic German authors, as Young had appealed to the Britons. He advocates Young's study of nature, but 1 "Werke," Vol. I, pp. 260-26r. 2 "Complete Works," Vol. II, p. 552. 
more particularly the study of German nature, and thus lends Young's fire to the already glowing flame of desire for national genius. ${ }^{1}$

The fourth chapter treats in a similar way and with like bearing the differences and development in religion that therefore beset the path of the imitator, with special reference to Klopstock and his school. Following this up in the sixth chapter, in reference to the restrictions of imitation due to the differences inherent in the natures of languages, he closes with a criticism that, he thinks, might justly be applied, and which might well have been uttered by Young: "The cold, rational Germans have tried to follow the flights of this ardent imagination [of the Orientals] with wings that nature did not give them." ${ }^{2}$

Then in the seventh chapter Herder continues, we should not imitate miserably; and to rid ourselves of such imitation he recommends that we study Oriental poetry as poetry, that we learn to interpret and to teach it. We can not translate and imitate it until we understand it, and, he says, "The Oriental philology that has flourished in our Germany for some time will, when it unites with taste, scatter miserable and stupid imitators." 3

It is interesting to note that here Herder uses bodily Young's figure to describe the advent of adult genius: "Aber es tritt ein Genie auf aus dem Gehirn des Jupiters!" " Young: "But a genius enters the field like Pallas out of the head of Jove." 5

In his treatise on Greek literature, ${ }^{8}$ Herder takes up Greek writers and pronounces them worthy of imitation, but, he says, "Before we imitate them, we must know them," " and for this purpose a suitable translation is necessary, such as Ebert's of Young, and such in fact as we might expect Young himself to ask for. In the succeeding chapters there follows an exhaustive discussion to

${ }^{1}$ Here we see the first beginnings of Herder's later intense interest in folkpoetry, when he, following his own advice as here given, won glory thru his promotion of German national poetry. It was this very study and return to nature as represented in "Percy's Reliques," and folk-poetry in general, that crowded out Young's "Night Thoughts," and thus, by the irony of fate, Young became the prophet of his own defeat.

2 "Werke," Vol. I, p. 273.

${ }^{3}$ Cf. ibid.

4 "Werke," Vol. I, p. 275. pp. $285-356$.

5 "Complete Works," Vol. II, p. 558. 7 Cf. l.c. p. 286. 
determine the merits of the German imitators of Greek poets, all of which carries out the principle of Young, - "Know thyself," and study the ancients in order to imitate them correctly.

Herder, like Young, distinguishes between correct and servile imitation, or, as Hamann called it, "Nachahmen und Nachäffen." 1 Herder expresses the former as "einen Alten nachbilden, und ihm nacheifern," the latter, however, as "ihn kopiren, und ihm ${ }^{2}$ nachahmen." The former, also, is very rare, he says. And he continues: "Therefore Young in his work on original composition is right, when he claims that the study of the ancients is in most cases detrimental; he is right, and yet it is not therefore necessary to dispense in the least with the study of the ancients." He cites Young, he says, because Rambach had recently refuted these arguments in his article. ${ }^{3}$ Herder doubts, however, that we are in as great need of original heads as some think, and wonders whether the benefits do not counterbalance the damage. "As soon," he continues, "as we praise, worship, and servilely imitate the ancients, simply because they are ancients; as soon as we borrow or steal from them, because we think that we shall thus become modern ancients, or modern in the taste of the ancients; then imitation is unbearable." $\mathrm{He}$ closes in calling "die Heerde Nachahmer," "das servum pecus," a Horatian phrase likewise applied by Hamann."

One of the finest expositions of the real merit of imitation in its highest sense Herder gives in the eighth chapter of his treatise, "Von der neuern Römischen Litteratur," 5 where he says, in substance: What is the meaning of better imitation? To imitate an author in his own words, to string together grammatically his expressions, is mere handicraft. And since we can not confine ourselves entirely to the vocabulary of a writer without external violence, one must fear becoming uneven in style. "But imitation to acquire the tone of the ancients? Such imitation is much more elevated, and a work of talent.

1 Cf. supra on Hamann, p. 37.

${ }^{2}$ Modern usage requires the accusative in this sense.

${ }^{3}$ Cf. supra, p. I7, 4I-42. Cf. also "Werke," Vol. I, p. 383.

4 Cf. supra, on Hamann, p. 37.

B "Ueber die neuere Deutsche Litteratur. Fragmente. Dritte Sammlung." 1767. Cf. "Werke," Vol. I, pp. 408 ff. 
If we read an author with the ardor with which he wrote, then he will needs inspire us, so that we shall be for a time transported, as it were, into his sphere; his music still resounds in our ears; we see with his eyes, we breathe in his sentiments, as if in our own element; the strings of poetical feelings respond within us, quickened by his; our words are formed in his manner; we read usque ad scribendi sollicitudinem - and write. Now his language lives in us; his rhythm resounds in our ears; the chain of his pictures stands before our eyes; we imitate his language, his meter, his style, and prove ourselves virtuosos. Now, I add, his ardor inflames our spirit, we create new figures in his pictures and recast his ideas; we form new figures after the model of his, we surpass him in an expression; a certain turn stands out in brilliant relief; we form a better simile, - we become more than imitators, we become rivals. Our copies become for us pleasing monuments. ... For the public these works are pledges of the worth of a man who developed himself so excellently after the model of the ancients, who knows so much of their spirit, who has assimilated the taste of ancient beauty, whom we must admire, of whom we can expect much." But such works, Herder concludes, can not, nevertheless, attain the standard of the ancients comparatively, as masterpieces; since the conditions under which they were written are so entirely different. And so, after all, the imitator of Horace, however excellent, sings out of Horace, not out of himself, as Horace did. ${ }^{1}$

Thus Herder reduces his argument ad absurdum, as it were; he shows that imitation, however excellent, remains imitation still; whereas, imitation of the method of authors, following their sources and not themselves, treating contemporary conditions in the manner employed by the ancients in treating their conditions, produces new masterpieces and creates originals. Here, then, Herder follows Young's distinction between real imitation, that of authors, and real originals, i.e. imitation of nature. ${ }^{2}$

${ }^{1} \mathrm{Cf}$. Young : "But suppose an imitator to be most excellent, . . . yet still he but nobly builds upon another's foundation." And: "An imitator shares his crown, if he has one, with the chosen object of his imitation." Cf. "Complete Works," Vol. II, p. 552.

2 " Complete Works," Vol. II, pp. $55 \mathrm{r}$ ff. 
Then Herder traces briefly the history of the servile imitation that had invaded, conquered, and oppressed Germany. We Germans thought, he says, in substance, we could express things more beautifully in Latin than in our own language; secondly, that the ancients had exhausted the realms of these beauties; ${ }^{1}$ thirdly, that we had inherited all these as incorporated in their works; and lastly, if we seized their expression, we also attained their spirit, and if not all their spirit, no matter. So we decided to write in their language; we avoided all that was not classical, so as not to deviate from the ancients; we sacrificed all originality, everything that might prevent our being called classical, and thus we became classical imitators! This hateful word "classical." It has crowded out all the culture that could have been derived from the ancients as living models, and has established the fatal fame: "To be a connoisseur of the ancients, to be an artist, without any loftier aim in view. This desire has buried many a genius under a rubbish heap of mere words, has made his head a chaos of exotic expressions, and has rolled the burden of a dead language upon him like a millstone. He has deprived his fatherland of blooming fruit trees; they now stand on foreign soil and mourn with half-withered blossoms and drooping leaves, whereas they ought to be trees under which posterity might dwell." This is the theme of servile imitation as found in the "Conjectures," and ends with a picture similar to that drawn by Young, when he calls the imitator "a transplanter of laurels, which sometimes die on removal, always languish in a foreign soil." 2

And continuing, Herder says, ${ }^{3}$ we ought to be taught by disastrous examples that if we prefer expression to thought itself, we produce that dead statue of style which is without faults, but also without especially individual beauties; without life or character, a boon for tedious readers, the admiration of the

1 Likewise in the second edition of the "Zweite Sammlung," Herder, in discussing the lyric, vents his sarcasm upon the universal wail, that Horace has completely exhausted the possibilities of the lyric. "O what Horatian despotism! Ye geniuses of lyric poetry! Let us forsake this servile land," etc. Cf. "Werke," Vol. II, p. I 79.

2 "Complete Works," Vol. II, p. 55r. 3 "Werke," Vol. II, p. 4 I4. 
ordinary fool, - but the wise man passes by. They shall see that what has been said ten times before is, however beautifully expressed, commonplace when repeated again.

Young likewise speaks of words tarnishing by passing thru the mouths of the vulgar, and of thoughts becoming too common. "We may as well grow good by another's virtue, or fat by another's food, as famous by another's thought. The world will pay its debt of praise but once, and, instead of applauding, explode a second demand as a cheat." 1

The same thought regarding imitation is again expressed in Herder's discussion of the modern use of mythology, when he ardently proclaims, in reference to Horace: "O that I might proclaim loud enough, that whoever imitates Horace, merely to imitate him and to depict a beautiful, regular, artificial, and learned skeleton of his odes, is nevertheless no Horace, if he does not attain the purpose of the ode and is not able to reveal the living thought to our senses." 2 And on the same page Herder speaks as pointedly against the idea that original production depends upon the observation of classical rules. "I am not bold enough, therefore, to be a lawgiver and to say, 'a heroic epic, a drama without Grecian or Roman cut is impossible.' If I should say that, Shakspere and all our unborn Shaksperes, whom we hope for our stage; Ossian and Klopstock, and all the Ossians and Klopstocks that we hope for, would cry out against me."

Investigating the function and place of mythology in literature, Herder attributes its beautiful development among the ancients to an intensely creative imagination and deplores the fact that the Germans have not made as good use of their natural advantages along the same line. It all resolves itself into the same question that Young discusses so fervently, the imitation of nature as opposed to imitation of authors. "Learn of them the art of gaining in your entirely different sphere a similar treasure of pictures. Instead of being satisfied with everything that Homer has given off, strengthen your intellects, so as to be able to drink from the ocean of sentiments and peculiarities that sur-

1 "Complete Works," Vol. II, p. 553.

2 "Vom neuern Gebrauch der Mythologie." Cf. "Werke," Vol. I, p. 437. 
round you, without expiring." 1 That is, specifically stated, do not borrow allegories from the ancients, but learn their art of allegorizing. These views Herder then exemplifies by applying them to German poets. Thus in this also he gives them a practical bearing for the advancement of German literature.

And so in his "Fragmente" Herder waged war against servile imitation and exhorted German writers to cultivate their powers and to produce originals, according to the precepts advocated by Young and voiced by himself in his second revised edition of these Fragments:" "Ye geniuses, who procure everything from the abyss of your souls, why need I tell you that out of the essence of our religion and nation, of our culture and philosophy, ... touching pictures of human effects and conditions can be drawn, that scorn even the altar of Bacchus?" If this were recognized and accepted, he adds, the Horatian ode would have to give way to original productions of imaginative genius, "living copies of an uncommon human soul, warm copies of feelings in their best hours; and as such how superior they are, in the eyes of the connoisseur of artistic temperament, to all stereotype imitations!"

And it is also in the second edition of his "Fragmente" 3 that Herder sums up his whole purpose and campaign, in words similar to those of Young's famous first paradox: "Let rivals be aroused, not imitators. The better the ancients are known, the less they will be plundered; the more fortunately they are imitated, the sooner they will be equalled. And that, finally, is a copying original (kopirendes Original), in which no copy is. evident; in which one creates of himself, following a Greek national author, a writer for one's own nation and language. He who is this, he writes for his literature!"

Early in life ${ }^{4}$ Herder says in reply to the criticism of the Litteraturbriefe - "no one should become a writer who has not read the ancients" - that this would rob us of all original writers; and near the close of his life, ${ }^{5}$ he writes similarly of the

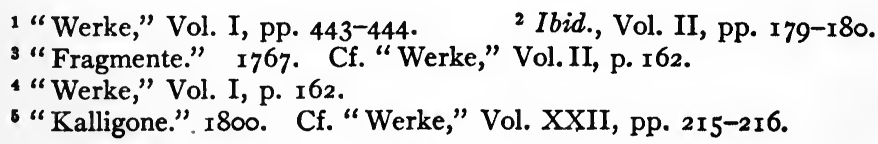


study of the ancients: "The mere study of the ancients, if it does not penetrate our very souls, but merely remains acquired knowledge, that, too, is lack of taste," - a reiteration of Young's point, that we must study and imitate not the works of the ancients, but their method and spirit.

In Herder's discussions of the value of rules there is also much that suggests Young's ideas on the subject. As Hamann says in particular of Homer, who was not conscious of the rules that Aristotle later deduced, Herder says of the poet of genius: "A man whose soul, pregnant with thoughts, yearns to be relieved, never stops to consider how some future esthetic rulesmith will work him over to collect examples of style for his text-books." 1 This last point, too, is found in Young, who says a genius is not in need of rules; they are an aid to the lame, an impediment to the strong. ${ }^{2}$

Herder takes up the same theme in his discussion of the critical analysis of works and the question whether a poet did or did not have in mind the rules that can be deduced from his works. "The greater he was, the less he burdened himself with definite, enervating rules; and it was the greatest genius who, when inspired by the muse, knew of no rule. A Sophocles thought of no rule of Aristotle; is not all of Aristotle contained in him nevertheless? The rules that the pedagog gathers from the 'Iliad' - for whom are they rules? For none !... For no genius that can make a way for himself, or that can take an original flight, and so forth, as the cabalistics of genius run. They are not to be rules at all; they are to be observations; enlightening, developing philosophy for philosophers, not for poetasters, not for self-governing poets." ${ }^{3}$ We are not to deduce rules to follow, he says, but to observe methods, and then profit by the mode of procedure. If this is not done, the poet himself is to blame.

In his article on Shakspere, discussing the drama of the ancients, Herder exclaims in words that are almost Young's own, "The art of their rules was - no art, was nature!" 4 And in his review of Baumgarten's ideas on natural esthetics,

\footnotetext{
1 "Werke," Vol. I, p. 402.

2 "Complete Works," Vol. II, p. 557.

s "Werke," Vol. IV, p. I9.

"Ibid., Vol. V, p. 2 Ir.
} 
he says: "Neither poet nor any ardent genius is conscious of rules, of partial conceptions (Theilbegriffe) of beauty, and laborious reflection. His power of imagination, his eagle eye for the unit, a thousand powers that arise in unison within him, are at work; and he is unhappy if a rule disturbs him." 1

Like Young, ${ }^{2}$ Herder gives genius a rank above philosophy; ${ }^{3}$ genius is dormant in man, as the tree in the germ; genius is awakened like every other power." Why, then, he says, is there such a lack of genius at the present day? "Why has there been such profound silence of late on our German Parnassus? Why has it almost become a fine art repository and workshop filled with impure air? - Genius has not died, but it is being held captive by rules, by patterns, by the ideals of our refined, critical, and moral age. Enervated in these bonds, enfeebled in the arms of Kalypso, it has not the necessary self-reliance; it has lost the desire and courage to exert its power, to become in the face of all the censors of good taste, not like them and others, but a great ego." 5

And then later, in another passage, he again takes up this point in a similar way, saying that nature is not so poor in geniuses as we think, when we consider as such only book and paper geniuses. "Every person of noble, living powers is a genius in his own way, in his own calling, and really, the best geniuses are found outside of the book room. ... As long as nature suffers no lack of sound germs and blossoming trees, she will not suffer any want of human geniuses. . . . Nature has noble germs enough; the trouble is that we do not recognize them; we trample them under foot, because we estimate genius mostly by deformity, by prematurity or exaggerated growth." 6

Compare with this Young, when he says: "But why are originals so few? Not because the writer's harvest is over, the great reapers of antiquity having left nothing to be gleaned

1 "Werke," Vol. IV, p. 23.

2 "Complete Works," Vol. II, p. 557: "Genius, therefore, leaves but a second place, among men of letters, to the learned"; p. 559: "Learning we thank, genius we revere"; p. 565: "The well-accomplished scholar ... is as the bright morning star; the second (genius) as the rising sun."
3 "Werke," Vol. V, p. 218.
Ibid., Vol. VIII, pp. 324-325.
${ }^{5}$ Ibid., Vol. II, pp. I78-r 79 .
Ibid., Vol. VIII, p. 223. 
after them; not because the human mind's teeming time is past, nor because it is incapable of putting forth unprecedented births; but because illustrious examples engross, prejudice, and intimidate." $1 \mathrm{He}$ deplores the great inferiority of modern authors - human souls in all periods are equal; genius is not so rare as we imagine, - "many a genius, probably, there has been, which could neither write nor read. So that genius, that supreme lustre of literature, is less rare than you conceive." 2

In view of these expressions on genius, it is very apparent that when Herder, in his "Metakritik" of Kant's philosophy," takes issue with Kant's thoughts on genius, he is wasting time quibbling over words, not thoughts. It is true, Germany had gone to extremes over genius, and the Geniekult had provoked considerable opposition and a marked reaction. Thus some of Herder's criticism is justified, but most of it is mere logomachy. His views are identical with Kant's, only expressed in different words. Let us compare the following criticism:-

(I) Kant says, "Genius is a talent, that talent to produce which no definite rule can be given; originality must be its first attribute." 4 In spite of the fact that Herder had voiced the same thought himself, ${ }^{5}$ he now quibbles with Kant by declaring that this is not only contradictory but misleading. "At all events, genius works according to rules, and is a rule unto itself, even granted that not every third person could point it out. The 'originality' of genius (a very much abused word) can only mean that the genius produces a work of his own powers, not imitated, nowhere borrowed; else there can be, as the 'Kritik' itself says, 'original nonsense."

(2) "The products of genius must be models at the same time, i.e. they must be exemplary, they must serve as criterion or rule for criticism." Against this Herder: "The work of genius exists, even if it is never imitated; it stands unique of its kind. For imitation, or much more, for criticism, the work was never created, and is desecrated by imitation without genius. Further,

1 "Complete Works," Vol. II, p. 553.

${ }^{2}$ Cf. ibid., p. 559.

3 "Werke," Vol. XXII, pp. I97 ff.

"For these quotations from Kant, cf. "Immanuel Kants Sämmtliche Werke." G. Hartenstein. Leipzig, I867. Vol. V, pp. 3I7-318. ${ }^{5}$ Cf. supra, p. 52. 
how different from each other are imitation and the rules of criticism! Genius steps forth neither as file-leader nor as automaton, untroubled whether or not it become a rule of criticism or model for imitation. Presumptuous imitation, injudicious acceptance as criterion or rule, pains genius." Again mere logomachy. Likewise :-

(3) "Since genius itself can not demonstrate scientifically how it creates its products, it claims nature as its rule." Herder: "To give this the work of genius was not produced; neither do nature and science declare themselves as opposites." This question is taken up similarly in the next point.

(4) "Nature prescribes rules, not for science, but for art, and this only so far as it is to be fine arts." Herder: "Neither for the one nor the other; both can, however, learn from that which is transmitted in a degree of perfection, as from example." In this Herder is quite right, and the point against Kant is well taken, and also in the following point. Herder's claim is very rational, altho in the strictest sense of the originality of genius, Kant is really in the right, but perhaps too severe in his reproach.

(5) "He who can never do more than learn and imitate is a simpleton." "That he is not," Herder objects. "If he learned faithfully and imitates exactly, he can with his acquired knowledge, with his faithful imitation of the most beautiful and best, become a wise, clever, useful man; else whole faculties and schools would be simpletons by profession."

(6) Kant contends that there is no specific difference between what can be learned according to rules of investigation and reflection (Forschung und Nachdenken) and what can be gained thru diligence by means of imitation. Thus one can learn all that Newton has contributed in his immortal work on the Principles of Natural Philosophy, but one can not learn to write with talent. Because Newton could have demonstrated, not only to himself but to every one else, all his steps, whereas Homer and Wieland can not show how their ideas grew in their minds. Therefore, in science the greatest inventor differs from the most wretched imitator only in degree. This Herder quite correctly denies. He who invents something in science, he says, produces, 
as well as the poet, something individual and new that he did not "learn." The more important it was, the more the inventor, a genius in science, differs from the learner and imitator. No scientific inventor belongs to the ranks of imitation, even among the foremost. What he invented he did not learn, and, furthermore, Homer and Wieland had to learn too.

(7) Herder claims that imagination and judgment are not the only requisites for genius, but reason alike is indispensable.

(8) Finally, Herder reaches the real normal level of his views on the subject, returns entirely to his original plane, and touches the real point at issue; the history of the world has proved that all progress is due to alert and inspiring genius. And because a few overbold youths misused the name is no excuse for the Germans to use the word as a term of ridicule and reproach. It is the noblest gift of heaven. "The ancients spoke less of genius, but honored and cultivated it perhaps more than we." 1 Then Herder proceeds to show what genius meant to the ancients and how the term has been abused in modern times. "The geniuses of the human race are its friends and knights, its protectors and helpers. . . . To arouse spirit, to animate forces, is their service and the reward of their services."

Much of this, to be sure, advances beyond Young's scope of literary criticism into the realms of philosophy, but the spirit and tenor is the same: except that Herder, abreast with the times, defends real genius in its noblest aspects and leads the reaction against the Geniekult gone mad.

And finally, altho Herder, in keeping with the progress of the ever increasing interest in Shakspere, goes far in advance of Young in his Shakspere criticism, it is interesting to note that he follows the same line of criticism as suggested by Young. The growth of Shakspere's popularity among the Germans was due largely to the fact that Young represented him as the great original genius of modern times, not the son, but the brother of the ancients. So Herder says: "Just there Shakspere is Sophocles's brother, where he is so unlike him in appearance merely to prove to be exactly like him in essence." ${ }^{2}$

1 "Werke," Vol. XXII, p. 202. Cf. supra, p. 20.

${ }^{2}$ Ibid., Vol. V, p. 225 . On p. 229 , Shakspere is called the "British 
Thus he applies to Shakspere words that are identical with Young's paradox: "The less we copy the renowned ancients, we shall resemble them the more." Young says Shakspere knew two books only, that of man and that of nature, ${ }^{1}$ and it is his ability to study and imitate nature that makes him supreme among moderns and equal to the ancients. Similarly, Herder calls Shakspere the son of nature, ${ }^{2}$ and the great imitator of all nature; ${ }^{3}$ and finally, he says Shakspere has no law but the faithful portrayal of nature and of man ${ }^{4}$ as revealed about him.

Herder, then, took up the ideas of originality in literature as preached by Young and corroborated by Hamann, and not only laid stress upon the same principles, but sought to exemplify them and to apply them for the purpose of arousing national pride in German letters. Thus he helped to free Germany from the servility of imitation and prepared the way for the literature that has made Germany famous.

\section{Conclusion}

Nature, originality, and genius were, then, the great watchwords of the poets of the Storm and Stress period. Shakspere was their favorite poet; for in him they saw the one upon whom genius had been most abundantly bestowed, the one who, without observing traditional rules, taking nature as his model, had created the most wonderful works, in all of which he had never failed to be entirely original. This enthusiasm, augmented by the introduction of Ossian, the Skaldic poetry, Percy's "Reliques," the study of Homer, Hans Sachs, etc., developed an ardent admiration for nature and folk-poetry, which was studied and imitated, and added new inspiration to poetic productivity.

Sophocles," and Vol. IX, p. 543, Herder says the two dramatists are not to be judged one by the other; they are incommensurable. It is true that Bodmer, as early as 1732 , in the preface of his translation of Milton, had called Shakspere the "British Sophocles"; but Bodmer wrote the name "Sasper," and so is hardly to be regarded as a possible source. Cf. supra, p. II.

1 "Complete Works," Vol. II, p. 574.

2 "Werke," Vol. V, p. 232, "Anhang"; cf. also p. 238.

${ }^{3}$ Cf. ibid., p. 248.

1 Cf. ibid., p. 245. 
How Goethe, Herder, Wieland, Bürger, in fact all the leading writers of the eighteenth century, took part in this movement is too well known to need repetition here and lies beyond the scope of this work. Goethe's "Götz von Berlichingen," "Die Leiden des jungen Werthers," Bürger's "Lenora," are prominent products of these years of the awakening of genius. Lenz, Wagner, Klinger, are all disciples of the reaction against rules and formalism. Their works, whatsoever may be said against them, breathe a freshness, a vigor and enthusiasm, a new life, that German letters had not yet seen; and much that the critics who followed Young had tried to accomplish was now fulfilled. 


\section{CHAPTER III}

\section{THE "NIGHT THOUGHTS" IN GERMANY}

\section{Historical Survey}

THE scattered notices in German periodicals ${ }^{1}$ of the earlier works of Young had indeed introduced his name into Germany, but there is no indication that these works attracted much attention; at least, they have left behind no trace in the literature of that early period.

The first important article on Young is the lengthy review of the "Satires" by Gottsched, in $1745,{ }^{2}$ which cites and translates numerous verses; but the work is attributed by Gottsched to Glover, and so it was left for Young's chief work, the "Night Thoughts," to make his name really known in Germany.

The "Night Thoughts" appeared at a time (I742-I745) when the more progressive minds of Germany were looking eagerly to England for new literary inspiration. North Germany was in close touch with England both geographically and politically, and was therefore especially open to English influence. On the other hand, in South Germany, English letters had won their most zealous devotees among the Swiss school of Bodmer; thus conditions were most favorable for the rapid spread of English literary influence.

The moral weeklies (Moralische Wochenschriften) that were modelled after the Tatler, Spectator, and Guardian, ${ }^{3}$ were the

${ }^{1}$ Cf. Bibliography, infra, p. 135 .

2 Since the material of this survey follows the chronological order of the Bibliography, Chapter V, only such works are cited as can not readily be found there under the given date.

3 The Tatler, published by Steele (I 709-I 7II), was followed by the Spectator, published by Steele and Addison ( $\left.17 \mathrm{II}^{\mathrm{I}} \mathrm{I} 7 \mathrm{I} 3\right)$. The Guardian was published by Steele in 1713 . 
principal medium thru which the first seeds of English inspiration were planted in Germany. Beginning with the Vernünfler in Hamburg (I7I3), ${ }^{1}$ these moral weeklies found so much favor and increased so rapidly that by the middle of the century over one hundred and twenty had led a more or less abbreviated existence.

The movement began with Milton. The Spectator re-introduced "Paradise Lost" ${ }^{2}$ into Germany, where it found response in translations ${ }^{3}$ and in the two prominent imitations: Bodmer's "Noah," and Klopstock's "Messias." After Milton came Pope, Addison, Dryden, Swift, Defoe, and others, who met with a hearty reception and were read both in the original and in translations. And so the way had been well prepared for the reception of the "Night Thoughts" in Germany.

Why were the "Night Thoughts" so eagerly received, so zealously and widely read and studied? Why were they able to exert so great an influence? The Swiss were interested in them especially, because the poem satisfied their requirements for a masterpiece. There was absence of rime, combined with the chaotic preponderance of the imagination, and the implicit acceptance of the mysterious and marvellous, - qualities that reminded them of the sublime piety of their master Milton. ${ }^{4}$

New models were sought, by the old school still among the French and the ancients, and by the new school among the English. This insured an introduction; but the "Night Thoughts" were assured a hearty welcome, because they were the expression of personal grief, of private cares. They struck a responsive chord in the tendency of the period to express its efforts, longings, and desires in pensive poetry. The writers of this period did not seek so much to portray lifelike pictures, as to allow the ego to give vent to its morbid and vaguely discontented feelings. There was dissatisfaction with social and

\footnotetext{
${ }^{1}$ Max Kawczynski's work on the "Moralische Wochenschriften," Leipzig, I880, gives an admirable account of these journals.

${ }^{2}$ A poor translation by Berge in 1762 had long been forgotten.

3 Bodmer, having become acquainted with "Paradise Lost" in a French translation in 1719 , at once began to translate it into German. He finished the translation in 1724 , but did not publish it until 1732 .

4 "Le Poète Edward Young," W. Thomas. Paris, I90I, p. 502.
} 
political conditions, from which men sought relief in literary expression; and this vague aspiration revealed itself in exaggerated sentimentalism.

Goethe characterizes the period in the Thirteenth Book of his Autobiography, showing how the serious German was especially attracted to this serious poetry of the English, and how the conditions prepared the way for his "Werther" and brought on a period of melancholy with not infrequent suicide. The same conditions made popular Gray's "Elegy," Akenside's "Pleasures of the Imagination," and similar works of Elizabeth Rowe, Ogilvie, Warton, Prior, and others, which, taken up by the sentimental current, increased its volume and momentum.

This is the background of the period of which the "Night Thoughts" were an integral part, and in which, because the Germans took Young seriously, they were able to play so important a rôle. They did not know that the three darts which the "insatiate archer" aimed at Young's happiness hit during a period of four years, and that he did not begin to pour out his inconsolable grief until some time after the taking off of his spouse, whose death he really does not mourn until the ninth "Night," almost five years after her death. They were touched by his grief, so they overlooked the artificiality of the "Complaint," and did not realize the bombast and insincerity of the poet-preacher, who was quite gay and dissipated in youth and was weaned from the world only when age overtook him. To the Germans, Young's life was that of a saint, his grief the wail of an immortal in the wilderness of mortal sins and weaknesses; and so the courtier and disappointed flatterer became for his cousins across the Channel the essence of all that is good and noble in the Christian, the guide to life, - a position that hypocrisy can hardly hold long. It is true, some of the sharper eyes penetrated Young's mask at once, but without effect. Wieland was the first great writer to be cured absolutely ( 1758 ), the rest suffered a longer delusion. In $\mathrm{I}_{772}$, Mauvillon and Unzer ${ }^{1}$ hit the truth when they said, "If we had been endowed with manly qualities and had not so much

1 "Ueber den Werth einiger Deutscher Dichter," etc. Frankfurt und Leipzig, I771-1772. Cf. I5th "Brief." 1772. 
childishness and effeminacy inherent in us, we should have scoffed and ridiculed the fool who depicts the world as a prison and a judgment-seat, with colors that he took from misunderstood and misinterpreted religious maxims."

$$
\text { I 746-I } 750
$$

Altho the first German translation of the "Night Thoughts" did not appear until $\mathrm{I} 75^{\mathrm{I}},{ }^{1}$ seven years after the completion of the ninth Night, there is sufficient evidence to prove that the poem had attracted attention much earlier and was read in the original, perhaps even before Young had published the last Night.

The first review appeared in the Göttingische Anzeigen, March, 1746, and speaks of the completion of the excellent didactic poem, the "nightothougths" ${ }^{2}$ of "D. Younge" in a way that suggests previous knowledge of the existence of the poem, in spite of ignorance of correct English orthography. The same impression is made by the second review, which appeared in June of the same year, in the Leipziger Zeitungen, and abounds in the highest praise for this "masterpiece."

The same year the poets Gleim and $\mathrm{Uz}$ begin an interesting correspondence on the merits of the "Night Thoughts," a proof that they had been studying Young's poems for years. Ebert is busy with the work during these years, studying and preparing for his life's work of translation and revision of the author who was to become his favorite. Klopstock, too, altho he did not learn English until some years later - and then from the "Night Thoughts" - is very familiar with Young's poem, as his letters prove; and the first cantos of his "Messias" already show Young's influence. Lessing, also, in his fragments, has left behind proof that the "Night Thoughts" had found response in his nature.

Two groups of writers were responsible for the rapid and certain spread of Young's meditations, - the Swiss and the coterie of the Bremer Beiträge. Bodmer published the first

1 Bodmer's fragments of I 749 not considered.

2 Corrected on p. 188 to the spelling "nightthougths." 
translation of verses from the "Night Thoughts" in his periodical Neue Critische Briefe (I749) and was then gathering from Young inspiration which was later to reveal itself

2) in his own work, the "Noah," in I 750. The poet Tscharner also studied the "Night Thoughts," and his early poems written in this period betray the influence of the "Complaint." But the group of the Bremer Beiträge, united in their common literary studies, were the most important factor, altho the results of their early interest did not appear until later. They were the literary "hot bed," so to speak, of the propagation of Young's nocturnal meditations.

These first five years after the completion of the "Night Thoughts" are, then, a period of study of that poem for the poets interested in Young; a period of preparation that was soon to yield a number of translations, among which at least one, that of Ebert, is a monumental work of zeal, interpretation, and scholarship; an example of literary style that did much to cultivate what Germany then needed, - a good, smooth, fluent prose.

\section{I $75^{I-I} 759$}

The Germans now became anxious to know what was the cause of Young's grief and who were the originals of the characters celebrated in the "Night Thoughts." Tscharner visited him in the spring of $\mathrm{I} 75 \mathrm{I}$, and his letter to Haller, published as preface in Kayser's translation of $175^{2}$ and in the later edition of $1760-176 \mathrm{r}$, furnished at least part of the information. ${ }^{1}$ While in London, Tscharner found time to translate the "Night Thoughts" into German hexameters, - a translation that never appeared in print.

But there was no lack of published translations. Ebert's was the first to appear. Early in $175 \mathrm{I}$, he published in prose the first seven Nights in what was planned to be a series of translations of the best English writers. But Ebert became

1 A certain Herr Majes of Hanover called on Richardson, in I759, to learn more about these things, but the outcome seems to have been as fruitless as Ebert's inquiry by letter. Cf. his undated letter to Young, I760-I $76 \mathrm{I}$; cf. also "Le Poète Edward Young," W. Thomas. Paris, I90I, p. I98, note 4. 
so engrossed in perfecting his rendition of the "Night Thoughts" and "Satires" that he never carried out his plan beyond the translation of the most of Young's works, exclusive of the tragedies and "Conjectures." This translation, favorably received and reviewed, was completed the next year and passed thru four editions, 1753 , I 756 , and $1763 .^{1}$

Two other translators, independently of Ebert, conceived the idea of translating the "Night Thoughts" about the same time and published their work in $175^{2}$; the one, Geusau, printed Night IV in Jena, the other, Kayser, a pastor living near Hanover, published Nights I-IV in Göttingen. Geusau's work is in miserable, monotonous, deadening Alexandrines, which, however, received favorable notices for being a means of helping to spread the work of "worthy Young." Kayser's translation, which owes its existence to the instigation of Haller, and contains as preface the letter on Young which he had received from Tscharner, is in hexameters and prints the original on the pages opposite. It was rather favorably reviewed by no less a critic than Lessing, who joins the Göttingische Zeitungen in hoping that Kayser will continue the translation. Lessing shows special interest in the data on Young, altho he can not think very highly of the hexameters.

The year 1754 brought, in a Hamburg periodical, the posthumously published translation of Night $\mathrm{V}$ by Oeder, the first translation in the original meter. Part of this was later used by Herder. ${ }^{2}$ The next year this was followed by an anonymous, weak translation of the first Night, this time in rimed trochaic

1 To suppose, however, that these editions were published regularly under these dates as indicated above, would give an incorrect picture of the state of things. An examination of all the editions available in Germany, both in libraries and book shops, failed to reveal a single copy of any edition, except the first, complete. The four editions were snatched up and bound together, as if the demand had been too great to supply. It is significant, further, that the other works of Young translated by Ebert and comprising volume two (r 7541756) did not pass thru a second edition, altho one or two copies were found with the date $\mathbf{I 7 6 2}$. It was quite customary to revise the date on the title-page of a reprint. It is further interesting to note that the fourth edition appeared $\left(\mathrm{I}_{7} \mathrm{6}_{3}\right)$ after Ebert had begun to publish his new, annotated translation with the original on the pages opposite, 1760 on.

${ }^{2}$ Cf. infra, p. Io8. 
octameters, published in Frankfort. In $175^{6}$, appeared a similar anonymous attempt, most likely by the same translator, upon Night IV, equally poor, but fortunate enough to receive the most lavish praise of Gottsched. Both of these octameter translations were reprinted with the addition of Night II, in I759, when they again received the warmest admiration of Gottsched, probably because they reminded him of his favorite French Alexandrines.

Besides these ten editions of the whole or parts of the "Night Thoughts," numerous translations appeared, before I760, of the other works of Young, all of which added to his popularity and thus helped to draw attention to the "Night Thoughts." But more or less directly in the wake of Young's poem there sprang up a host of minor imitations, morose and gloomy complaints and sentimentally sorrowful lyrics; and the moral weeklies were filled with ephemeral literature that gave clear evidence of the effect of Young's nocturnal melancholy. ${ }^{1}$

During this period Klopstock learned English from the "Night Thoughts" and, filled with admiration for the work, he wrote his ode to Young ( $\left.175^{2}\right)$, one of the most reverent tributes ever paid the "Author of the Night Thoughts." Together with his wife, Klopstock carried on an interesting correspondence during these years with Young and Richardson.

Bodmer, too, studied, reviewed, and recommended the "Night Thoughts," and both he and Klopstock are of especial importance, because their epics spread Young's tone and increased the desire to write in his manner.

Lessing and Gottsched reviewed the translations, the latter, however, betraying his ignorance of the "Night Thoughts" in speaking of the rime of the original.

The Bremen group and their associates, Uz, Creuz, Cramer, Gellert, Cronegk, etc., are giving evidence in the fifties of their study of the "Night Thoughts"; and others, Hamann, Zimmermann, Crugot, Lavater, etc., celebrate "Solitude" and similar themes in Young's tone.

Wieland, in this his hypersentimental period, is entirely under the spell of the English poet, an attitude which suddenly

${ }^{1}$ Cf. infra, pp. 102-105, for list. 
developed into as intense disgust and hatred. After about $\mathrm{I} 75^{8}$, Wieland would hear nothing more of the "Night Thoughts."

The pinnacle of fanatical admiration was reached that year, when J. A. Cramer, in his periodical Der Nordische Aufseher, extolling religion as a passion, calling affectation, as exemplified in Young's "Night Thoughts," reason in religion, and branding everything less ardent as undevout, called Young a genius far sublimer than Milton and of all human beings next to David and the Prophets. This was too much, and immediately the Bibliothek der schönen Wissenschaften took issue with Cramer and not only dealt out justice to Milton, but assigned to Young his proper level. Lessing, too, in the Litteraturbriefe (I759) rejected this praise as exaggerated, but not as strongly as one would expect and as Nicolai was bold enough to do a little later.

And so already in this decade, which abounds in increasingly intense admiration of Young, the reaction has begun, a movement that gained greatly in extent and influence during the next decades.

\section{I $760-1770$}

In spite of this feeling against Young and his followers, Ebert had a new edition of the "Night Thoughts" I-IV ready for the press in 1760 , and this time, after the style of Kayser's I $75^{2}$ edition and in compliance with the wish expressed by several critics, with the English text on the pages opposite. But Ebert had to outdo Kayser, and so he published copious notes to elucidate and interpret difficult passages and to point out all the thoughts in Young that the latter had borrowed from his predecessors, or that his successors had taken from him. The nine Nights were completed in this new edition by I769, and the first six had passed thru a second edition. A reprint of the first eight Nights of this translation, in three volumes, was published in Schaffhausen ( $1765-1768)$, the fourth volume containing the last Night not appearing until I774.

Indefatigable in his zeal, Ebert also published, under a new title, an edition of the complete "Night Thoughts," following 
the new edition of $1760-1769$ as far as that had been completed, i.e. Nights I-VIII, but without notes or English original.

All these editions were abundantly reviewed in the contemporary periodicals, mostly with favor. Almost every one who was at all favorably disposed toward Young praised Ebert's zealous labors and saw in his harmonious prose a perfect reproduction of Young's verse. The value of the notes was the subject of the most discussion. As a rule they were considered a splendid, erudite assistance to the mastery of Young's excellent poem, but grave doubts were expressed by many on the real value of such copious remarks; they were regarded as a hindrance rather than aid and above all as a mere attempt to spread bombastically a mass of affected knowledge.

One writer, Dusch, altho he heaped praise upon Young, angry that his own translation of Pope had not been accorded the same appreciation, and jealous of Ebert's reputation, not only contested the latter's superiority, but even tried to prove to the world that his translation of Pope was equal and even superior to Ebert's rendition of the "Night Thoughts."

In spite of the new, enlarged, annotated edition, Ebert found, in 1763 , a market for a fourth edition of his original translation of $175^{1-1} 75^{2}$, revising the text of Nights I-VIII according to the new edition.

Kayser, too, encouraged by the success of his $175^{2}$ translation of the first four Nights in hexameters, added the remaining Nights in the same meter and published them in I760-I76I at Hanover, illustrating each Night to make the book more attractive. This translation was also the subject of much criticism. Considerable fault was found with the hexameters; but most critics considered it an excellent piece of work, one going so far as not only to declare it superior to Ebert's rendition, but to pronounce Kayser superior to Ebert as an English scholar.

In addition to these two principal translations, an anonymous translation was published in $176 \mathrm{I}$, a rearrangement of the "Night Thoughts," grouping the best sentiments under sixteen topics with the title "Moralische Gedanken über verschiedene Gegenstände der Religion," which was also graciously received. 
Even the miserable, anonymous translation in octameters of Nights I, II, and IV was reprinted; Young's name was used in anthologies to add to their attractiveness and importance; the moral weeklies continued to draw material from the "Night Thoughts," and numerous works on literature, English writers, and the like, contained estimates of the "Night Thoughts" with praise for Young.

Even French translations are dragged in thru reviews in all the leading periodicals, and every one seems anxious to say something about the great poem. During these years Ebert is giving English courses in the "Night Thoughts" at the Carolineum; and Klopstock, in his treatise "Von der heiligen Poesie" ( 1760$)$, discusses the work at length and pronounces it the only example of sublime poetry that deserves to be without a fault. Young's satires, tragedies, and other writings continue to receive attention and add to his glory.

Gerstenburrg reviews the "Night Thoughts" with ardor; Dusch is influenced by them; Schubart is busy with them; Knebel is rescued from the abyss of doubt thru them and is held spell-bound; Herder begins his active work with them; Lenz imbibes them; Hamann continues his studies in them; and the youthful Goethe uses them as his English reader. But worse than all this, scores of poets imitate lamely: they are lonesome and sad, they have night thoughts on all occasions, even on pleasure trips; they "Youngize" without cause, simply because that is the current fad.

What could be so inevitable as a reaction against all this folly? Möser pleads for life and humor in his "Harlekin"; Jacobi satirizes and ridicules these "funeral bards" and "black prophets"; and Heinse considers these imitations, and even Young's "Complaint" itself, mere affected grief. But the most effective cuts were given by Nicolai and Klotz. The former, in the Litteraturbriefe ( $176 \mathrm{I})$, reproaches the Germans with a shameful desire to flock weakly in droves after one single genius who has entered a new field, whether he be a German or foreigner. Now comes Young, he says, with his complaints, and all our poets are sad, they are lonesome, they gush forth complaints and know not why; the very mob that was revelling in anacreontic songs 
a decade ago is now incapable of anything but sadness and seriousness, simply because it is the fad of the day. These Nachtgedankenmacher are a disgrace to the nation.

But Klotz, in his Deutsche Bibliothek (I768-1769), is the bitterest anti-Young critic. He not only pronounces the "Night Thoughts" repugnant to every person of good taste, but even attack's Youngs views of life as false and disgusting. He calls the style affected, inclined to be mystical and obscure, and pronounces the conception as well as the execution of the whole plan poor and unfortunate. Young is for him the king of night owls (Uhus), the source of corruption in English poetry, and a menace to German letters.

This decade is, then, the most prolific in editions of German translations of the "Night Thoughts," the richest in influence upon German writers, and most pervaded with enthusiastic interest in the "Night Thoughts." But it also produced a decided increase in the reaction against Young and his imitators. that had been evident since the time of Wieland's conversion in 1758; a reaction that grew steadily from now on and made itself felt especially in the next decade.

\section{77 I-I 779}

This decade presents an interesting picture. Not a single new attempt is made during this period to translate the "Night Thoughts" or any other work of Young. Periodicals contain reviews of three different French editions of the "Night Thoughts," and of the sixth volume of Young's works in London. An English edition of the poem is published in Hamburg, and some unimportant discussions of Young appear; otherwise the field has been surrendered to Ebert.

Two reasons may be assigned for this lack of translations, both having their origin in timidity: first, the scathing reviews of the preceding decade against the "Night Thoughts" and especially against their German imitators may either have disheartened the would-be translators, or may have converted them and turned their talents in other directions; and secondly, the success of Ebert may have crowded them out of the field, 
which they resigned to him quite willingly, thinking, perhaps, that no new translation was necessary in the face of his perfect work.

At all events, as opposed to the failure of a single new translator to appear, Ebert continues his editing with undiminished vigor. Besides a new edition (the third) of his translation of the "Resignation," and five of the "Satires," as well as a new edition of all the other works that he had translated, Ebert published, in Braunschweig, the second edition of Nights VII-VIII of the annotated edition that had appeared in the preceding decade; and a new edition of the 1767 edition of the complete Nights. Volume IV of the Schaffhausen edition appeared (I774), containing the ninth Night, as well as a complete reprint of this edition, comprising all the Nights in four volumes (I 776-I 777).

Basedow arranged a chrestomathy in Ebert's translation of Young's best thoughts, for use as a text-book on morals and religion (1778). And this tells one of the secrets of the success of Ebert and of his continued output of new editions. The religious and moral maxims of the "Night Thoughts" were excellently adapted to ecclesiastical work; they formed a good companion piece to the catechism and litany, and went hand in hand with the Bible itself. But we must not forget that Ebert was a pedagog, and as professor of English offered courses in the "Night Thoughts" at the Carolineum in Braunschweig. His annotated edition was the text-book and many editions were necessary to supply his pupils, - perchance a vulgar use for such a work, but a practical application.

Influence upon the literature of the period has not ceased. Goethe writes his "Werther," a product to a large extent of the literary tendencies that followed in the wake of the "Night Thoughts"; Schiller is in his Klopstock-Young period; Jean Paul, Tiedge, and others have joined the scores of Young's followers, and the poetasters continue to flood the press with their ephemeral lucubrations.

But the reactionists, too, Jacobi, Heinse, etc., have received new forces; Michaelis, Wetzel, and others continue to put forth their satire and endeavor to crowd the "Night Thoughts" 
out of the field; and Herder, altho he calls Young the foremost of all gloomy poets, finds fault with his chaos of thoughts and figures, and prophesies that the imitators of Young and Hervey, the Schmierer von Nachtgedanken, must finally become the most distasteful of poets.

The Frankfurter Gelehrte Anzeigen (1772) also show a decided antipathy toward the "Night Thoughts," but most important of all are the attacks by the critics Mauvillon and Unzer (177I-I772). Starting with Gellert, they attribute to him an exaggerated influence, which made the widespread potency of Young's "Complaint" possible. And then, coming to Young himself and his imitators, these critics dwell upon the absurdity of Young's irreconcilable grief, however sad his bereavement; and they express their wonder and surprise that he was ever so much admired in Germany and was allowed to do so much damage to literary taste, whereas in England his popularity had waned at once. For this these critics make the Germans themselves responsible and reproach them with their weakness in allowing their "Anglomania" to carry them off their feet.

This tirade supported very effectively the position taken by the reactionists of the preceding decade and was undoubtedly largely the cause of the lack of new translators in this decade. But we must not imagine that the Germans were cured of imitation. The other phase of Young's influence was now at its zenith, i.e. the cry for originals which was nourished by the "Conjectures," and "Night Thoughts" imitation had to go with the rest.

But the special cause of the turning away from the "Night Thoughts" is rather to be found in the increasing predilection for Ossian and Percy's "Reliques." Thomson's "Seasons" and Young's "Night Thoughts" had taught the Germans how to express their feelings freely; but such poetry, together with Gray's "Elegy," Akenside's "Pleasures of the Imagination," and the like, did nothing more. It inspired them to religious, melancholy reflection, too metaphysical and conventionally affected to touch the heart deeply, sincerely, or with a satisfying effect. It emancipated the ego to a certain extent, but did not teach the profoundest secrets of nature that Wordsworth, for 
instance, later revealed. It is a transition to subjectivism, which prepared the way for the voice of nature as effectively revealed in the folk-poetry. This added a new source of interest and inspiration for imitation and emulation, because they were originals and nourished the spirit of the times that raved over originals. Homer and Shakspere, also, were chief models, not as works to be imitated, but as writers who depicted nature faithfully and whose method was to be imitated and was to furnish the secret of success.

Thus, in distinction to the preceding decade which was the period of the greatest influence of the "Night Thoughts," in this decade the reaction against Young and his imitators had reached its height. From this time on, altho there continues a more or less pronounced predilection for Young on the part of a certain class of writers, it is less fanatical and extensive than before, and, compared with the feeling of opposition which continues to work hand in hand with the increasing desire to cultivate original genius, is weak and undecided, and of minor importance.

$$
\text { I 780-I } 789
$$

In this decade it is very evident that the reaction against Young has not only been successful in limiting and almost stopping imitation of the "Night Thoughts," but Young is fading away from the public gaze and is rapidly being forgotten. Ebert's translation is reprinted in Speier, in a library of religious and moral works ( 1780 ), and a supplementary volume is added ( 1782$)$ in Frankfort; Herder uses some verses of Night II in his "Briefe das Studium der Theologie betreffend" (I780), but beyond this little activity is evident.

In $\mathbf{1} 780$, also, Professor Eckert in Mannheim presumes to revise Ebert's translation in a new edition under the title of Young's Complete Works, to which he adds a translation of two of the tragedies, in $I 784$, when the whole edition appeared in five volumes. But the periodicals are silent. Even Ebert receives no notice; anthologies and works on literature scarcely mention the "Night Thoughts," and the German translation of a French chrestomathy, "Moralische Betrachtungen über 
den Werth des Lebens," passes without notices. In fact, the only attempt that receives the attention of critics is the hexameter translation of the "Night Thoughts" by Steingrüber, and the criticism of that seems to have been written chiefly to find fault with the use of hexameters in German.

The former admirers of Young are silent. Schiller has turned from Klopstock and Young, and only a few of the youngest poets consider Young a force. Jacobi and his reactionists are joined by Matthisson, Wagner, and others, altho their zeal is scarcely any longer necessary. To offset this, of course, the idea of original genius has risen in strength proportionately, and nature, as found in the folk-song, Shakspere, and Ossian, is the leading source of inspiration.

That Germany had gained its equilibrium as far as fanatical admiration and imitation of the "Night Thoughts" is concerned, is attested by one writer at least. C. F. Cramer, in his work on Klopstock, correctly characterizes Young's influence upon the times and furnishes proof, conceding him to be representative of the times, that the literary world had begun to realize the truth.

\section{790- 1800}

But for Ebert, the "Night Thoughts," at the end of the century, would have been decidedly a thing of the past. Ebert seemed to feel, however, that he must bring the study of his favorite poet to a successful close by editing a last edition that would include the results of his investigations since the annotated edition of the sixties; and so, in the years I 790-I 794, he published what he himself called the final edition of the "Night Thoughts" and "Satires," and then laid down his pen forever. But his editions lived on. He had begun to publish a final reprint of the edition of 1767 , without notes, but only Volume I, containing the "Night Thoughts," appeared (I79I); the volumes containing the other works of Young were delayed until after his death, Volume II appearing in 1799.

In this decade Herder still draws upon the "Night Thoughts" in the Neue Deutsche Monatschrift (I795), and numerous selections are included in anthologies and collections, but without 
special emphasis upon Young. The writers of this period who mention Young in their works are either cool or decidedly antagonistic, and the once ardently admired poet is now almost totally rejected.

It was reserved, moreover, for one of the warmest of these admirers, Herder, to give the last important estimate of the century, and that was rendered with a coolness that leaves beyond a doubt the fact that the Germans had at last completely recovered from the Young epidemic. Herder expresses his surprise, as he reviews the movement, that Young was ever considered a deep thinker, and claims that no work is to be read with so much caution as the "Night Thoughts"; and Schiller, in his essay on "Naïve and Sentimental Poetry" (1795-1800), brands Young as the least competent guide to life.

Thus the "Night Thoughts" ran their course in the second half of the eighteenth century, rising to an extremely sublime height and then sinking to the very unimportant position of a school text; for Herrmann, Gymnasium teacher at Wismar, published the last edition of the century, not a translation, but the English text, with notes from Ebert, to make the mastery of Young's difficulties of style easy for all German students of English.

\section{I802-1903}

The edition of Hermann (I800) gives the keynote of the position assigned to Young from that time on - that chiefly of an academic problem. Only isolated editions appeared and quite independently of any movement for or against Young. The year 1802 brought a reprint of Eckert's I780-I784 editions; Halem's Irene contained a blank verse translation of Night I, the next year; and the year 1805 saw the publication of the last reprint of Ebert's I 780 edition. Selections translated by Schneller appeared in $18 \mathrm{I} 2$, and then no attempt seems to have been made to translate the "Night Thoughts" until 1825. In the meantime various short biographical sketches of Young were published in literary treatises, mostly of a bibliographical or academic nature. 
The year 1825 , however, produced two translations, both in the original meter: one by Schmidt in Dresden, comprising only the first six Nights; the other by Bentzel Sternau of the complete nine Nights, published in Frankfort, and reprinted in Vienna, in 1827 .

The next attempt is made by Elise von Hohenhausen (1844), who painfully endeavors to reproduce Young line for line. The poetess, if her knowledge is typical of the period, shows that nearly all the translations of the "Night Thoughts" had been forgotten, even those of 1825 , inasmuch as she claims that her translation is the first attempt at a rendition in German blank verse. Reprinted about 1874 , this translation remains the very final one of the "Night Thoughts."

With the exception of these translations, the "Night Thoughts" were since 1825 the subject of no special attention until toward the end of the century, when they were taken up for discussion and treatment in dissertations and school programs, magazine articles, and casual mention, as a phenomenon of the past, interesting for what they had been to preceding generations, not for what they mean to the present.

\section{INFLUENCE UPON GERMAN WrItERS}

\section{(a) The Swiss School and Didactic Poets}

The Swiss, having sprung into prominence thru their controversy with Gottsched, were exerting a potent influence upon the literary taste of the Germans at the time when the "Night Thoughts" appeared. From about 1740 to I755, they were the wonder and admiration of Germany and, in fact, their influence continued more or less up to the time of Bodmer's death ( 1783$)$. Opposed to Gottsched's predilection for the French, the Swiss sought inspiration in the ancients, on one hand, and in the English, on the other. Against Gottsched's view that poetry is a mere matter of rules and correct form, Bodmer and his school looked upon poetry as the creation of the imagination and the passions, food for the heart. These 
poetical ideas won the day, and thus English letters gained a welcome and a prestige that soon dominated all Germany.

\section{JOHANN JAKOB BODMER (I698-I783)}

Bodmer, the principal figure of this group, early learned English, and was led thru his study of Milton to other British writers and to Young, whom he does not mention until after the "Night Thoughts" had appeared." His first contribution to the study of Young was published in the Neue Critische Briefe, in I749, where the "Satires" and the "Night Thoughts" are introduced. These fragments are the first translation of verses of the "Night Thoughts" published in Germany.

The hexameter epistle "An Sipha" is in part a translation, in part a paraphrase, of Night II, verses $46 \mathrm{I}-537$, and the selections translated in a later article of the same periodical are from Night VI, verses 627-648, 677-689, in well-executed blank verse. The sentiments of these passages are judged superior to a similar passage in his own poems. The Crito, ${ }^{2}$ in $\mathbf{I} 75 \mathrm{I}$, reviews Ebert's first translation and recommends the "Night Thoughts" very highly to its readers; it also publishes critical and moral remarks on the first Night.

Bodmer's biblical epics and his tragedies were greatly influenced by the "Night Thoughts." This is especially true of the "Noah." Ebert has ferreted out and cited in his edition thirty-five passages which show Young's influence. The minor epics, too, collected as the "Calliope," 3 show abundant influence of the "Complaint," and the influence on the tragedy "Johanna Gray" is proved by Bodmer himself, when he cites passages which he owes to Young." It is, finally, interesting to note Bodmer's request, in $\mathrm{I}_{7} 6_{5}$, for a copy of Ebert's annotated edition of the "Night Thoughts," that he might be able to see how many times and how exactly he has imitated Young.

${ }^{1}$ Cf. infra, pp. I20-I21 ; also, Bibliography, infra, I 749.

${ }^{2}$ Cf. Bibliography, infra, I75I. ${ }^{3}$ Zürich, I767.

"Cf. "Drey neue Trauerspiele." Zürich, I761. “Johanna Gray," pp. 77, 89, 94.

5 Letter to Pfarrer Schinz in Altstätten, Aug. 30, 1765 . 


\section{Albrecht von Haller ( $1708-1777$ )}

Haller's "Lehrgedichte" exhibit the same serious, moralizing tone that characterizes the "Night Thoughts," but one can hardly speak of Young's influence on Haller's writings; for all of his important poems antedate the "Night Thoughts," and the minor poems after I74I are of little consequence.

Primarily a scientist, he was, however, deeply interested in literature and philology, and as editor of the Göttingische Gelehrte Anzeigen he rendered an invaluable service to literary criticism. Haller inspired translations of works of several important writers, ${ }^{1}$ among them Kayser's translation of the "Night Thoughts," 2 the preface of which is from a letter to him from Tscharner, written while in London the year before. His correspondence with Tscharner, especially the reply to the abovementioned letter, ${ }^{3}$ shows deep interest in Young, and the review of Kayser's translation ${ }^{4}$ shows clearly his predilection for Young's muse.

Ebert cites twelve passages of the "Über den Ursprung des Úbels" (r734), which have parallel thoughts in Young's "Complaint." ${ }_{5}$ In view of this spiritual kinship it is futile to call later similarities influence. Haller was rather one of the spirits that paved the way for the "Night Thoughts" in Germany and promoted their influence.

\section{Vincenz Bernhard Tscharner ( $1728-\mathrm{I} 778$ )}

Tscharner was one of the pioneers in translating the "Night Thoughts." During his visit in England, in $175 \mathrm{I}$, he spent four delightful days with Young at Welwyn, and his subsequent letter to Haller ${ }^{b}$ gave the Germans the first definite data to satisfy their intense curiosity to know the identity of the persons

1 "Albrecht von Hallers Gedichte." Dr. L. Hirzel. Frauenfeld, ז882, pp. cccxiii ff.

${ }^{2}$ Cf. Bibliography, infra, 1752, r 760-1 $76 \mathrm{r}$.

3 Dated, Göttingen, March 28, r 75 r.

- Cf. Bibliography, under Kayser's translation, infra, 1752.

In the r790-r 794 annotated edition.

- Cf. on Haller, supra. 
and events treated in the "Night Thoughts." While in London Tscharner found time to translate the "Night Thoughts," at least in part, into German hexameters, the first Night of which has been preserved in Haller's correspondence, but was never published. ${ }^{1}$

Of his youthful poems, "Freundschaftliches Geschenke," 2 the one entitled "Abend-Gedanken, von dem Zustande der Seele nach dem Tode" especially shows influence of Haller, Klopstock, and Young. His feelings, altho sincere, are inclined to be mawkish with sentiment and are not always the result of real experience. ${ }^{3}$

\section{Friedrich CARL Casimir von Creuz (I724-I770)}

Creuz, a melancholy soul, was especially susceptible to the influence of his contemporaries. Among the German poets, Klopstock and Haller, among the English, Young, exerted the greatest influence upon him. In common with Young he was of an exceedingly religious nature and very much given to rhetorical effects. His principal poem, "Die Gräber" (I760), is written in a tone even gloomier than Young's and lacks the Christian hope which brightens Young's despair. Like Young, Creuz is full of repetitions; he lacks constructive ability and is overcome by his feelings to such an extent that his train of thought is broken, his pictures remain vague and lose their effect.

Ebert cites only two passages from Creuz that he considers influenced by the "Night Thoughts," " but this has further been increased by the investigations of Hartmann, ${ }^{5}$ Bion, ${ }^{6}$ and Barnstorff, ${ }^{7}$ who cite innumerable parallels, so that one must not only agree with Hartmann, that Creuz was inspired by the "Night Thoughts" to write his "Gräber," and with Barnstorff,

1 "Vincenz Bernhard Tscharner, von Gustav Tobler." Bern, I895, p. 27.

${ }^{2}$ Printed as appendix to "Poèsies choisies de $M$. de Haller, traduites en prose par M. de T. Gottingue, I 750."

${ }^{3}$ Cf. Tobler, l.c. p. 3 I.

${ }^{4}$ In the I 790-I 794 edition.

- Cf. ibid., 1894.

${ }^{6}$ Cf. Bibliography, infra, I89o.

7 Cf. ibid., 1895 . 
who says that the "Gräber" are, with all their differences, only a weak echo of the "Night Thoughts"; but we can go further and pronounce them fairly teeming with thoughts from Young.

\section{(b) Gottsched and his Followers}

\section{Johann Christopher GotTsched (I700-1 766)}

Gottsched, whose attitude toward the English was not at all friendly, and who attacked the "Conjectures" severely, ${ }^{1}$ was rather pleasantly disposed toward the "Night Thoughts." That he and his wife, "Louise Gottschedin," early became acquainted with Young's "Complaint," is proved by a letter from the latter to a friend in sorrow, whom she advises not to read Young too zealously, lest her grief be increased and her melancholy make Young's pictures seem even blacker than he intended them. ${ }^{2}$

Gottsched's review, in 1757 , of the anonymous, metrical translation that had appeared the year before, praises both the original and the translation, citing verses freely to prove its merits. $^{3}$ And when this same translation was published, in 1759, together with Nights I-II, ${ }^{4}$ he likewise reviewed it with praise and admiration. They are miserable attempts, but Gottsched's predilection for French Alexandrines made him partial to these rimed octameters, as we have seen, so that he preferred them to Ebert's "insipid" prose. That Gottsched is glad that the translator has retained the rime of the original does not speak well for his knowledge of the "Night Thoughts"; neither does the fact that he had forgotten Kayser's translation of $175^{2}$, and did not recognize the "new" verse translation as the one he had reviewed before. ${ }^{3}$ But most peculiar of all is the failure to mention the "Night Thoughts" in his "Handlexicon" of 1760.5

${ }^{1}$ Cf. supra, pp. I5-16.

${ }^{2}$ Letter to Fr. v. R., Leipzig, Aug. 22, $175^{2}$.

${ }^{3}$ Cf. Bibliography, infra, 1756.

4 Cf. ibid., 1759 .

- Cf. ibid., I 760 . 


\section{Daniel Wilhelm Triller ( $1695-\mathrm{I} 782$ )}

Altho Triller's poems of complaint and sorrow on the death of his wife, "Klage-und Trauergedichte," Wittenberg, I752, are worthless verses, they deserve mention here, because they show the early development of the desire to poetize grief, a tendency which can, to a large degree at least, be attributed directly to the "Night Thoughts." Triller confesses his inferiority as a poet, but he says he can not but desire to erect a monument in his lowly song to the worthy memory of his departed spouse.

\section{Christoph Otto von Schönaich (1725-1807)}

In his polemic, "Neologisches Wörterbuch," 1 Schönaich cites "Pop und Jung" as "unsterbliche Namen -

"Die, wie ein loser Schalk hinzusetzte, Namen, Die niemals unentweiht von B-dm-rs Lippen kamen."

This apostrophe to Pope and Young was expurgated in the r765 edition. ${ }^{2}$

\section{(c) The Group of the "Bremer Beiträge" and Similar Poets}

The polemics between the Swiss and Leipzig schools degenerated into petty personalities and exposed Gottsched's weaknesses to his admirers. As a result they forsook him and formed a literary circle of their own. They also severed their connections with the periodical published by Gottsched's circle, Belustigungen des Verstandes und des Witzes, and as a means of publishing their productions they established their own periodical, Neue Beiträge zum Vergnügen des Verstandes und Witzes, usually called Bremer Beiträge from the fictitious place of publication. It appeared from $\mathrm{I} 744$ to $\mathrm{I} 748$, being

1 "Die ganze Aesthetik in einer Nuss oder Neologisches Wörterbuch von Christoph Otto Freiherrn von Schönaich," I 754. Reprinted in "Deutsche Litteratur-Denkmale des 18. und 19. Jahrhunderts." Vols. LXX-LXXV.
A. Köster. Cf. p. 335 .
${ }^{2}$ Cf. ibid., p. 536 . 
then continued desultorily by others until $\mathrm{I} 759$. The purpose of the publishers was to keep aloof from all party polemics, to cultivate original composition and the translation of foreign works, submitting their contributions for the approval of the members. In order to insure proper, unprejudiced criticism, every contribution had to be published anonymously. They rejected French models and turned to the ancients and the English for inspiration. Among the latter, the novels of Richardson and the "Night Thoughts" of Young nourished an elegiac, sentimental vein, which manifested itself in tearful, emotional gush over friendship and kindred themes. ${ }^{1}$

\section{Johann ARnold Ebert (1723-1795)}

This professor of English in Braunschweig, ${ }^{2}$ the first translator of the complete "Night Thoughts," one of the ablest German translators of English writers in the eighteenth century, and who devoted the best part of his life to the works of Young, learned English early and read all the foremost British authors in the original. Altho he was an ardent admirer of Young, he was not at all blind to the latter's faults, nor did he fail to appreciate the works of Young's fellow-countrymen.

In 1744 he is reading the most prominent English authors, he writes to Hagedorn, ${ }^{3}$ but he does not mention Young. Four years later he writes of "divine Thomson," he sighs for the latter's poem on freedom, he will never tire of reading Glover's "Leonidas," and weeps over it; he has copied nearly all the sublime passages of the "Night Thoughts," and speaks of a few inferior passages that he would willingly "buy out" of the work, so ardent is his admiration for this wonderful genius Young. He even excuses them, as a last resort, since he can not render them unwritten, on the ground that only so exalted a genius could make such errors. Pope will charm him to his dying day, he says. He writes of plans to translate various

${ }^{1}$ Cf. the introduction by Franz Muncker to the "Bremer Beiträge." Vol. XIIII of Kürschner's "Deutsche National-Litteratur."

2 Appointed instructor at the Carolineum in 1748 , professor in 1753 .

' Letter to Hagedorn. Leipzig, July 29, 1744 . 
English authors, but does not include Young! ${ }^{1}$ In fact we do not hear of his translation until the next year. ${ }^{2}$ In an undated letter to Young, ${ }^{3}$ he writes that he has had Young in his thoughts fifteen years, and has been translating the "Night Thoughts" about ten years. This would place his first acquaintance with the work in or about the year $1746 .{ }^{4}$

Ebert's letters to Young are filled with the mawkishness characteristic of the times and furnish a vivid picture of his unbounded esteem for the author of the "Night Thoughts," 5 all of which Young accepts with thanks, complimenting Ebert, in return, on his perfect English, ${ }^{6}$ and hoping they may meet in heaven.

Beginning with the year $175 \mathrm{I}$, Ebert published translations of the "Night Thoughts" and other works of Young, constantly revising them until I794, the year before his death. Other editions appeared even after he had laid aside his pen forever. ${ }^{7}$ The notices of Ebert's courses at the Carolineum in Braunschweig repeatedly announce the critical interpretation of the "Night Thoughts," and all contemporary writers, commentators, and periodicals join in the universal acclamation and praise over the zeal, scholarship, and merit of the "foremost and greatest English scholar and genius," the translator of the "Night Thoughts."

Ebert, in spite of, or perhaps rather on account of his ardent admiration of Young, ${ }^{8}$ attempted no poem in imitation of him. The style and nature of his poetry is utterly different from that of Young. His longer poems are epistles called forth by some

1 Letter to Hagedorn. Leipzig, Jan. I5, 1748.

${ }^{2}$ Letter of Gleim to E. v. Kleist, Halberstadt, Aug. 24, I 749.

${ }^{3}$ Most likely written in the winter of $1760-1761$.

" The year following the completion of the "Night Thoughts," and the time of the first notices in Germany. The beginning of his translation would thus have to be placed in $1749-175^{\circ}$.

"Young was chosen, he writes, "by the all-gracious providence of God" to be his guide in heaven, where he hopes he may be allowed to mix his "tears of joy with those of all the blessed souls" to whom Young's excellent writings have been a means of salvation.

- Ebert's correspondence with Glover and Ferguson also shows how highly these writers esteemed his culture and taste.

${ }^{7}$ Cf. Bibliography, infra.

${ }^{8}$ Cf. Ebert's poem on Young ( 1760 ). Cf. Bibliography, infra, I 789. 
ephemeral occasion and amount to little as poetry. His general note is one of lightness, buoyancy, and love of nature. His early poems (1740-1747) contain twenty-three anacreontics, and this anacreontic tone appears in his later verses too. We look in vain for unconscious adaptations of thoughts from Young. The same painstaking care to enlighten his readers that is seen thruout the copious commentary on the "Night Thoughts" and "Satires," led Ebert to inform his readers from what source he drew his ideas. Thus the footnotes cite all passages where Young is mentioned, adapted, imitated, or even thought of.

Ebert's services were very valuable for the development of the German language and literature. Germany had no good prose, in fact it had but few monuments of literature. Ebert introduced poetical inspiration from abroad and set a worthy model for smooth, harmonious, rhythmic prose.

\section{JohanN Adolf Schlegel（I72I-I793）}

Ebert cites four passages of Schlegel's sermons that have parallels in the "Night Thoughts"; also the kindred sentiments in the epic poem "Der Unzufriedene"; and no doubt Schlegel owes to Young much of his serious vein. ${ }^{1}$ Young's favorite themes are found in Schlegel; there is the same praise of the Creator, celebration of friendship, love of virtue, and serious consideration of death and immortality that characterizes the "Night Thoughts"; but it is an extensive reflection of Young, rather than a tangible, verbal correspondence.

\section{JohanN ANDreas Cramer (1723-I788)}

It is not necessary to look further than the article written by Cramer in his periodical, in $1758,{ }^{2}$ to see that he was one of the most ardent admirers of Young. He considered Young

1 Cf. Max Koch: “Über die Beziehungen der englischen Litteratur zur deutschen im achtzehnten Jahrhundert." Leipzig, 1883, pp. $19 \mathrm{ff}$.

${ }^{2}$ Der Nordische Aufseher, Kopenhagen und Leipzig. Vol. I, St. 13, pp. 158-182. Cf. also, Bibliography, infra, $175^{8}$. 
a genius not only far superior to Milton, but among mankind the one nearest the spirit of David and the Prophets. He gave the "Night Thoughts" second place to the Book of Revelation only, in their sublime influence upon his soul. The same article contains an analysis of the "Night Thoughts" with frequent quotations from Ebert's translation, which he praises warmly. Cramer's sermons are replete with maxims and citations taken from the "Night Thoughts," and his poems, too, were greatly influenced by the Briton. Like Schlegel, Cramer as theologian deals principally with Young's favorite themes, the treatment of which betrays close acquaintance with the "Night Thoughts."

\section{Nikolas Dietrich Giseke (I $724-\mathrm{r} 765)$}

Altho Giseke writes of whiling away the time of grief with "night thoughts," 1 that can only serve to show that he read Young, a fact that could safely be assumed for him as one of the group of the Bremer Beiträge. Giseke had a special penchant for poems upon the death of friends and others, and these memorials exhibit certain traits common to Young's philosophy. There is this cardinal difference, however, between the two poets: where Young bewails the loss of his kin in exaggerated, inconsolable grief, Giseke is simple and direct in style, and evinces a healthy, manly spirit that is free from Young's wail. It may be characterized by the following passages:-

"Wie billig hältst Du ietzt den Gram für Deine Pflicht:

Doch unterliegen muss ein edles Herze nicht!"

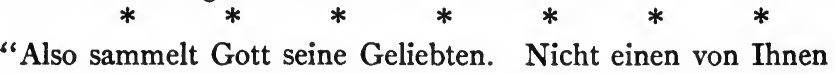

Lässt er zurück in den Thälern der Müh'! Er sammelt alle.”

This strain runs thru all his poems; it is consolation rather than complaint. The theme of friendship is a favorite with him, and the treatment of this approaches more closely Young's more buoyant moods.

1 "Poetische Werke," C. Ch. Gärtner. Braunschweig, 1767. Cf. the 6th "Brief," p. 404. Does he mean Young's "Night Thoughts"? 


\section{Friedrich Wilhelm Zachariae (1726-1777)}

As a colleague of Ebert at the Carolineum, Zachariae was brought into close touch with English poets, and his translations of Milton and Warton attest his interest in English literature. In his correspondence we find him early an admirer of Young, but the most direct proofs of his interest are found in his verses themselves. We have the word of his friend Ebert that the most remarkable correspondence in Zachariae's poems, in which he expresses almost verbatim the opening of the "Night Thoughts," is a mere coincidence. But there are other passages in his poems, written after his acquaintance with the "Complaint," that are modelled after Young. The poems "Die Erscheinungen" and "Die Nacht" show this influence especially, and even "Die Tageszeiten," an imitation of Thomson's "Seasons," mentions Young. But the poem "Die Nacht" shows the greatest influence of the "Night Thoughts," and not only mentions Young and Ebert in glowing tributes, but borrows Young's pictures in describing the night, and makes free use of passages of the "Night Thoughts."

\section{Christian Fürchtegott Gellert (1715-1769)}

Gellert learned English from Ebert and so naturally studied Young's "Night Thoughts." His correspondence refers constantly to Young and furnishes us with one of the best contemporary pictures of the universal interest taken in the author of the "Night Thoughts." Gellert's moral essays teach Young's philosophy and were a potent factor in spreading interest in the "Complaint" in Germany. He often cites Young and on one occasion criticises the "Night Thoughts" in words of ardent admiration. ${ }^{1}$ So potent and widespread was Gellert's influence, that contemporary critics attributed to him directly the "moral prattle" that allowed Young to become so popular in Germany, and made him responsible for the warm reception accorded to Ebert's translation. Young and Gellert had ruined taste, they

$$
1 \text { "Sämmtliche Schriften." Leipzig, 1867. Vol. VI, p. I80. }
$$


claimed, and to the Litteraturbriefe was due the credit of effecting the reaction against this barbaric Gellertomanie. ${ }^{1}$

In view of the intense interest taken by Gellert in Young, one would look for tangible influence of the Briton upon the German moralist; but the similarity is in most cases to be attributed to kinship of thought and purpose rather than to direct imitation. At least, Gellert believed himself free from imitation, and any use of Young was unconscious. The passages that seem traceable to Young are very likely accidental, and owe their origin rather to that part of Young that Gellert had so thoroly digested that it had become part and parcel of his own mental resources.

\section{Johann Wilhelm Ludwig Gleim (I719-1803)}

One of the first German writers to discuss the "Night Thoughts" was Gleim. In a letter to Uz, as early as I746, he writes that "the English seem to have the Horatian ode in several poetical types; for example, the 'Neight-Thoughts' of 'D. Joung,' the continuation of which is said to have appeared, seem to lack nothing but a better meter, a plan, and different rhythm to be an ode." ${ }^{2}$ This shows that Gleim had been following and studying the "Night Thoughts" as they appeared in England. Later in the same year he recommends that the Germans discard rime and enjoy the same freedom that English has in its blank verse, and again cites the "Night Thoughts." 3 In I749, he announces to E. von Kleist that Ebert is translating the "Night Thoughts," and praises both the original and the unpublished translation."

Two years later a reaction has set in; he does not admire the poem as much as formerly; the great artificiality of style has

1 "Ueber den Werth einiger Deutscher Dichter," etc. Frankfurt und Leipzig, I77I. Mauvillon und Unzer. I4th "Brief," pp. 30I-3r2.

2 "Briefwechsel zwischen Gleim und Uz," C. Schüddekopf. In "Bibliothek des litterarischen Vereins in Stuttgart." Vol. CCXVIII, p. III. Cf. letter, dated Berlin, June 30 , I 746.

${ }^{3}$ Cf. ibid., p. 134, letter, dated Berlin, Nov. 22, 1746.

4 "Kleists Werke," A. Sauer. Berlin. Theil 3, p. 108. Cf. letter, dated Halberstadt, Aug. 24, I749. 
never pleased him, he writes, and now he discovers entirely too many false thoughts which have no foundation of truth whatsoever.

$\mathrm{Uz}$ had criticised Young to Ebert, who was translating the "Night Thoughts" at the time, and Gleim conjectures that this did not please the translator. The translation Gleim pronounces unimpeachable and says Young has become a German original thru Ebert; but he regrets that Ebert did not choose a worthier poet to translate. ${ }^{1}$ And yet, in $176 \mathrm{I}$, he thanks Zachariae for Ebert's new translation and says he now thinks day and night in the "Night Thoughts," as Klopstock did."

But the "Night Thoughts" found no soil in Gleim's poetical field, to take root and spring up in imitation or influence. Gleim's muse was not compatible with Young's, the two poets had nothing in common; their philosophy of life was different, as is attested by Gleim himself, when he refused Young the recognition that he would gladly accord to even Ebert: "Young is no savior of men; I will not erect a monument to him. His translator Ebert would receive a memorial for his cheerful songs sooner than Young for his black 'Night Thoughts."' 3

\section{JohanN Peter Uz (1720-1796)}

In his earlier years a lyric poet of the anacreontic school, during his whole life a follower and admirer of the French and ancient classics, opposed to the English authors of his own times, Uz, nevertheless, was one of the first German poets to study the "Night Thoughts." As early as 1747 , in the very midst of his anacreontic period, we find him busy with Young's poem, writing his criticisms to Gleim." The style of the "Night Thoughts" seems to him sinnlich, but, as one might expect of him, a lyric poet of so light a vein, not simple enough. The

${ }^{1}$ Cf. "Briefwechsel," etc., l.c. p. 229. Cf. letter, dated Aug. 29, r75r.

${ }^{2}$ Letter, dated Jan. 25, r76r. Cf. Neue Jahrbücher für Philologie und Paedagogik. Vol. CXIV, p. 4rr.

3 "Briefe von den Herren Gleim und Jacobi." Berlin, r768. Vol. I, p. 297. Letter to J. G. Jacobi, Feb. I7, r768.

1 As appears from Gleim's letters, the two poets had for years been reading and discussing the "Night Thoughts" as the various Nights appeared. 
most elaborate odes of Horace, he writes, are not so rich in bold figures. Such superfluity does not please him, especially since he doubts their correctness. ${ }^{1}$

In $175 \mathrm{I}$, he has read Ebert's translation with pleasure, but again complains of the complex, ornate style of Young and the other Britons, as compared with the simplicity and good taste of the ancients. He thinks the prevailing German imitation of such writers will corrupt German poetry anew. ${ }^{2}$ But as he develops, Young seems to satisfy him better; for three years later he calls Ebert's translation beautiful, and thinks Young has outdone himself in the last Night. ${ }^{3}$

The further $\mathrm{U}_{z}$ developed his more serious side, the more Young could find response in his muse, and so it is very natural to find as motto of the first letter of his "Versuch über die Kunst stets fröhlich zu seyn" (I 760), a sentiment from the "Centaur," while the fourth letter is introduced by a passage from the "Night Thoughts," i.e. from Night the fourth. Ebert himself cited no less than nineteen passages of his friend's poems that show kinship with Young, and there is no doubt much influence, but even here only the lighter, brighter strains in Young's gloom found response in $\mathrm{Uz}$.

\section{JoHANN Friedrich von CroNegK (I73I-I757/8)}

Associated with the writers of the Bremer Beiträge, Cronegk, having learned English, naturally was deeply interested in the "Night Thoughts." His "Lehrgedichte" show influence of Young, but it is in the two poems "Einsamkeiten," written in loneliness, separated from his friend and his sweetheart, and after the death of his mother (I757), that we find the greatest influence. Young's muse is invoked, phrases and sentences are taken over bodily, and the whole work shows imitation and

1 "Briefwechsel zwischen Gleim und Uz." Cf. l.c. p. I55, letter, dated Jan. I9, I 747 .

${ }^{2}$ Cf. ibid., p. 224.

${ }^{3}$ Westermann's Monatshefte, Vol. II, p. I02. Cf. letter, dated Nov. I8, I754.

"In the epistle to Ebert ( 1755 ) Young is named; he sings in a manly tone, even when he weeps. Cf. verses 107-ro8. 
borrowing from Young on every page. Cronegk's figures, even where modelled after Young, are plainer and inferior, and his complaints seem to smack of the lucubrations of the times rather than to represent spontaneous grief. Mendelssohn, provoked at this addition of "Einsamkeiten" to the already superfluous crop of melancholy poetry, pronounces this genre imitation of Young and inveighs bitterly against such inane, affected grief. ${ }^{1}$

\section{FRIEDRICH VON HAGEDORN (I708-I754)}

Hagedorn said of the two years spent in England (I 729-I 73I), that they were the only two years of his life that he wished to live over again. He was intensely interested in English literature, but Pope, Shaftesbury, and Prior are his models. The writers of the Bremer Beiträge loved and honored him as a father, and his interest in the English, combined with the influence of their intimate relations with the Swiss school, furthered their English studies; but his light, anacreontic muse had nothing in common with Young's "Complaint." Yet even he has left behind a testimonial of his interest in the "Night Thoughts" in a letter to Ebert, which says, "One can not read your translation of the 'Night Thoughts' without the most grateful thanks for your successful labors." 2

\section{(d) The Göttingen League (Dichterbund)}

These writers, united thru their intense admiration for Klopstock, stand in their somber, melancholy elements more on the side of Klopstock himself. Among the foreign writers, they were influenced by Gray, Akenside, and Ossian, and altho Young was a favorite of some of them, the tangible influence that came from the "Night Thoughts" is very meager.

${ }^{1}$ Cf. Briefe, die neueste Litteratur betreffend. 207th "Brief." I76r.

${ }^{2}$ Feb. I4, I 753. 


\section{Friedrich GotTlieb Klopstock (I724-1803)}

Of Germany's greatest poets of the eighteenth century, Klopstock was the most sympathetically allied to Young in spirit and purpose. Both were of the narrower religious type and sought to spread their views in didactic verse. His associations with the contributors to the Bremer Beiträge, and especially with Ebert, led Klopstock to the English of the day, and as early as 1748 he cites a passage out of the "Night Thoughts" in a letter to Bodmer." Likewise the next year he consoles Sucro, thru a letter to Gleim, with a verse from Young. ${ }^{2}$ But this acquaintance must have been based upon the intervention of friendly help, rather than independently upon the study of the original, or else his statement, when he writes in $175^{2}$ that he has just begun the study of English from Young's works, ${ }^{3}$ must not be taken too literally. His letters as late as I773 evince the greatest admiration for Young; he exchanged some ardent letters with Young himself and also sought intercourse indirectly in his wife's letters to Richardson. Young's letters to Klopstock are full of the warmest thanks and appreciation. In $175^{2}$, while busily engaged in reading the "Night Thoughts" in the original, Klopstock wrote his ode to Young, which shows the depth of his admiration for the aged author of the "Night Thoughts."

In his treatise "Von der heiligen Poesie," published in the early editions of the "Messias," he pronounces the "Night Thoughts" the "only work of the more sublime poetry that would deserve to be without fault," and writes further with the most ardent admiration. The death, soon after their marriage, of Meta, ${ }^{5}$ drew Klopstock closer than ever to Young's "Complaint" and made him still more subject to influence from that source.

${ }^{1}$ Langensalza, Oct. I9, I 748.

${ }^{3}$ Letter to Gleim, Kopenhagen, April 9, 1752.

${ }^{2}$ Kopenhagen, July I3, 175 I.

"Halle edition, I760. Accessible in Back and Spindler's "Sämmtliche Sprachwissenschaftliche und ästhetische Schriften." Vol. IV, Leipzig, 1830. Cf. also, ibid., pp. II 5-122, and Klopstock's "Sämmtliche Werke," Göschen. Leipzig, ז844. Vol. V, p. 47.

5 Married r754. Her death occurred in $175^{8}$. 
Ebert cites sixty-one passages that show Young's influence upon the "Messias," "and this is increased by scores in Hamel's recent investigations; ${ }^{2}$ and Barnstorff adds still more. ${ }^{3}$ Altho Milton was Klopstock's model, there is no doubt that Young's influence was as potent as has been claimed by modern critics, as well as by the contemporaries, C. F. Cramer and Clodius. It is the lyric element in Young that attracted him as to form, but there is this cardinal difference between the two poets: Young is free from mysticism, whereas Klopstock is inclined to it. ${ }^{4}$ Klopstock's odes, of his earlier period especially, and other poems, as well as his prose writings, all show abundantly the influence of Young's didactic, religious muse.

\section{FRIEDRICH LEOPOLD GÜNTHER GöCKINGK (1748-1828)}

The light, idyllic, and often anacreontic muse of Göckingk had no desire to express itself in morose complaints. His satirical vein was nourished by his associations with Michaelis, who, too, was hostile to Young. Göckingk's satire "Golddurst" betrays familiarity with Young's "Love of Fame," 5 and the verses entitled "Die Nachtgedanken-Schmierer" are undoubtedly directed against Young's followers in Germany :-

\footnotetext{
"Bei Gräbern und bei alten Kirchenmauern

Will Stentor künftig trauern.

Der Dinge natürlicher Lauf !

Denn heute kündigt' ihm sein Wirth die Wohnung auf!" •
}

Likewise the poem "An den Tod," written after the death of his wife (I8I4), seems especially directed against Young's "Complaint": -

\section{"Wohl sollt' ich itzt nach dir mich heiserrufen! \\ Den Traurigen bist du ein Gut!}

1 Klopstock told Ebert that he used to read the Psalms and the Prophets, and the "Night Thoughts," for inspiration while working on his "Messias." Cf. Ebert's "Episteln und vermischte Gedichte." Hamburg, r789, p. 298.

2 Kürschner's "D.N.L." Vol. XLVI.

3 Cf. Barnstorff, l.c. pp. 36-37.

- Cf. ibid., p. 34 .
- Cf. infra p. 123.

- "Sinngedichte." Leipzig, I 778 , p. 84 . 
Allein hinan des Lebens letzte Stufen!

Denn diess will grössern Muth.

Was schwerer ist, war immer meine Sache.

Wie? dennoch wollt' ich schon hinab,

Gleich einem Weib', auf meinem Thränenbache

Mich schwemmen an das Grab?"

* $* * \quad * \quad * \quad * \quad * \quad *$

"Ha! kann mein Dulden ihre Ruhe mehren:

So soll die Trauer gehn!"

But a little later a change has taken place in the poet of seventy. The French harass and plunder his house, and then, in his trials and tribulations, his muse is his only consolation. In the poem "An die Dichtkunst" (I8I7) he pays a glowing tribute to the faithfulness of the muse:-

"Doch auch da ${ }^{1}$ hast du mich Trauernden nimmer verlassen, Durch die Harfe Young's gütig beschwichtigt den Gram, Wog ich Leben und Tod mit der Sterblichkeit Wage,

$\mathrm{O}$ wie dünkte mich dann Leben und Sterben so leicht!" 2

\section{Friedrich LeOpold Stolberg (I750-I8I9)}

Stolberg was one of the most thoro students and ardent admirers of Young, ${ }^{3}$ as is proved by the numerous passages in his letters cited by Janssen in his compilation on the life-work of the Count." Letters to his brother, sister, and others, written upon occasions of sorrow and joy, literary criticism and political conditions, have recourse to citations from Young for corroboration. ${ }^{5}$ Still one looks in vain for influence of Young upon the poems of Stolberg, in spite of his love for both Klopstock and

${ }^{1}$ During the French invasion.

2 "Gedichte. Neue verb. u. verm. Ausgabe." Frankfurt, I821.

3 This influence began in his home training; for we learn that his mother spent the whole day before the birth of a younger brother ( $176 \mathrm{I}$ ) reading the seventh Night. For this son the Countess chose Dr. Young to be sponsor, an office that he accepted as a very high honor, hoping to meet his little godson in heaven. Cf. Ebert's undated letter to Young and Young's reply, in Ebert's "Episteln und vermischte Gedichte." Hamburg, I 795, pp. 79-80, 84.

4 "Friedrich Leopold Graf zu Stolberg. Sein Entwicklungsgang und sein Wirken im Gebiete der Kirche." J. Janssen. Dritte Auflage. Freiburg, I882.

${ }^{5}$ Cf. ibid., pp. 32-33, 43, 25I, 273, 404, 455, etc. 
Young. His poems are odes, ballads, and sonnets, largely occasioned by particular incidents, many written upon the death of relatives and friends. The poet wanders and sings in the night-time, but he never descends into the depths of the "Night Thoughts." $\mathrm{He}$ is buoyant even when afflicted with grief, and the light touches of sorrow remind one of Ossian rather than of Young. Even the sublimest and most philosophical of his poems, the one that shows the greatest depth and genius, "Die Zukunft," ${ }^{1}$ does not remind one of Young, altho some nature descriptions have an Ossianic touch. ${ }^{2}$

In the third volume of his works, verses from various authors are used as mottoes for the poems, but Young is not included. ${ }^{3}$ Perhaps the correct hint for this lack of influence and imitation may be found in the couplet "An einen Nachahmer":-

"Kannst, armes Wichtchen, du nichts anders, als nachahmen, So musst du wenigstens nachgehen, und nicht nachlahmen." 4

At all events Stolberg did not practise imitation of others.

\section{(e) Philosophical Poets}

\section{Martin Crugot (I725-I790)}

Here it is the philosophically religious work "Der Christ in der Einsamkeit" (1756) that interests us. Immediately upon its appearance a periodical pointed out its similarity to Young ${ }^{5}$ and a French translation is said to have borne upon its title-page the inscription "Par l'auteur des Nuits de Young." 8 Ebert, too, saw influence of Young in this work of Crugot and cited six examples. Crugot philosophizes over life, death, and immortality in Young's manner, but he is less abstruse and ornate. Night is his favorite time for meditation, and only in lonely

1 Written $1779-1782$, but not published until 1885 , in Archiv für Litteraturgeschichte. Vol. XIII, pp. 82-I 15, 251-272.

${ }^{2}$ Cf. ibid., p. 90.

3 "Gesammelte Werke." Hamburg, 1827.

"Cf. ibid., Vol. II, p. I12.

Schlesische Berichte von gelehrten Sachen. Vol. XXIV, 1756.

- Cf. Barnstorff, l.c. p. 64 . 
surroundings does he feel at home with himself. The influence is beyond a doubt very strong, altho, on account of the inherent difference between philosophical thought and poetry in a philosophical vein, it is confined to thought rather than shown in form. ${ }^{1}$

\section{Johann Georg Zmmmermann (I728-1795)}

Zimmermann likewise celebrates the theme of solitude and has many points in common with Young. His earlier writings "Betrachtungen über die Einsamkeit" (I756) and "Von der Einsamkeit" (r773) and the later final work "Über die Einsamkeit" ( $1784-1785)$ are written in this vein. But is it not significant that the author cites numerous writers: Cicero, Plato, Plutarch, Horace, Diogenes, etc.; among the English, Pope, Johnson, Bacon, and others, but does not mention Young? The correspondence between the thoughts here expressed and similar ones in Young are even vaguer than in the case of Crugot, and one is rather inclined to look upon this as a similarity of philosophy of life and not as a case of direct influence.

\section{JoHANN KASPAR LAVATER (I74I-I80I)}

Lavater's work "Aussichten in die Ewigkeit" deals philosophically with the same themes found in the "Night Thoughts." But Lavater says in his first epistle that he can not consider Young's "Night Thoughts," however excellent they are, since they deal more with immortality of the soul in general than with the nature of immortal life $;^{2}$ and further, that Young's arguments can not convince him of the immortality of the soul. ${ }^{3}$ Likewise, in the second part, he mentions Young twice and

1 Against Crugot's work was directed "Der wahre Christ in der Einsamkeit," by Karl Friedrich Bahrdt (1741-1792), Halle, 1 762 ; Leipzig, I 764, - a work written in a more cheerful mood and showing joy in life, rather than consolation in solitude and in thoughts of death. Then, in turn, there appeared two pamphlets against Bahrdt, which it was not possible to find: "Etwas an Herrn M(agister) K. Fr. Bahrdt, seinen verbesserten Christen in der Einsamkeit betreffend," Berlin, I764; and "Zwei Briefe an M. K. Fr. Bahrdt, über seinen verbesserten Christen in der Einsamkeit." Breslau, 1764 .

${ }^{2}$ Cf. second edition, Hamburg, I773, p. 5. $\quad{ }^{3}$ Cf. ibid., p. 23. 
allows part of the "Night Thoughts" to stand along with Racine as the only examples of poems written for the glory of the truth of the best religion. ${ }^{1}$

The real influence of Young upon Lavater appears earlier in life. G. Gessner, in his life of Lavater, ${ }^{2}$ gives letters that prove zealous study of Young. What Lavater says here of time and eternity is an echo of Young. Further, an entry in his journal, in $176_{3}$, tells of a visit with his friend Spalding in Barth, during which they discussed the gain in cultivating such serious poetry as Young's "Night Thoughts" and Klopstock's "Messias," as opposed to the loss of time devoted to trifling, childish poetry.

\section{(f) Other Writers}

\section{JoHaNN JaKob DUSCh (I725-I787)}

The first article written by Dusch on Young is a harsh review, in I759, of Ebert's translation. ${ }^{3}$ Piqued by the shortcomings found in his own translation of Pope, as we have seen, and covetous of the universal praise that was being accorded Ebert's rendition of the "Night Thoughts," Dusch translated the "Resignation" in $1763 . "$

In the second part of his "Briefe zur Bildung des Geschmacks" 5 he has a long critique of the "Night Thoughts," which shows that he admired the work to a degree that made him blind to its faults and exposed him to censure. ${ }^{6}$ And so it is not surprising to see his work on the immortality of the soul ${ }^{7}$ draw upon Young's "Night Thoughts." This influence was pointed out in a contemporary review, which dwelt upon the inferiority of Dusch to Young. ${ }^{8}$

In the introduction to his works, Dusch characterizes the

${ }^{1}$ Cf. ibid., Vorrede, pp. vi, xiv.

2 "Lebensbeschreibung von G. Gessner." Winterthur, 1802, Chapter VIII.

3 In "Briefe an Freunde," etc. Cf. Bibliography, infra, I759.

'Cf. Bibliography, infra, 1763 .

S Cf. ibid., 1765 .

- Allgemeine deutsche Bibliothek. I768. Vol. VII, ii, pp. 142-r59.

7 "Sämmtliche Poetische Werke," Part I. Altona, I765.

- Allgemeine deutsche Bibliothek, I767. Vol. V, i, pp. 2-8. 
"Night Thoughts" as follows, "Solemn, exalted, majestic, the characteristic tone being the hyperbole." $1 \mathrm{He}$ states that he has indicated all passages in which he himself is conscious of any imitation; accordingly, there are many footnotes referring to Shakspere, Milton, Addison, etc., and in his poem "Die Wissenschaften" three notes cite passages from Young.

\section{Johann Georg Hamann (r730-1788)}

That Hamann thought all his opinions a mere afterbirth of Young's "Night Thoughts," and that he considered all his caprices impregnated with Young's figures, we have already seen, ${ }^{3}$ as also the fact that there are few ideas that can safely be traced directly to the "Night Thoughts." " Hamann often mentions the "Night Thoughts" in his writings, and always with favor, frequently citing from them.

In $175^{6}$, his mother died and he gave expression to his grief in the eulogy, "Denkmal," which bears as motto the following sentiment from Young's "Night Thoughts": "He mourns the Dead, who lives as they desire. Die beste Trauer um die Todten ist ein Wandel nach ihrem Sinn." 5 This expression of grief reminds one of Young's "Complaint," altho it is in plain, direct prose. The influence of Young was asserted as early as 1762 by Thomas Abbt, who saw in the work the same style, thoughts, and transition from one subject to the other. ${ }^{\circ}$

\section{Heinrich Wilhelm von Gerstenberg (I737-I823)}

Gerstenberg stands in peculiar relations to Young. A critic and student of the drama, enthusiastic over Shakspere, he belongs to Young's school for the promulgation of original genius, as has been seen, ${ }^{7}$ and, on the other hand, he defends both Young's "Night Thoughts" and their German imitators.

1 Cf. "Werke," l.c. pp. xxiii, xliv.

${ }^{2}$ Cf. ibid., 68, 89, 121-122.

5 Königsberg, den I6. des Heumonats, I756. Cf. "Schriften." Roth. Vol. II, pp. 329-338.

${ }^{6}$ Letter to Mendelssohn, June 21, I 762.
3 Cf. supra, p. 29.

4 Cf. supra, p. 40.
7 Cf. supra, pp. 22-26. 
His poems show the influence of Ossian, ${ }^{1}$ not Young, to be sure, but he espouses the cause of Young against the opponents who attack the "Night Thoughts" and their influence.

In the Briefe über Merkwürdigkeiten der Litteratur ( $\mathrm{r} 766)^{2}$ Gerstenberg compares the Danish poet Tullin with Young and Pope, in words that attest his high esteem of Young. He says, "You can easily see that I must have a high opinion of him (Tullin), when I give him so exalted a rank," i.e. compare him with Young. His reviews, too, in the Hamburgische neue Zeitungen ( $1767-\mathrm{I} 77 \mathrm{I})^{3}$ mention the "Night Thoughts" many times and always with admiration. He takes sides with Young against Gleim who would not give Young a memorial, ${ }^{4}$ and against Jacobi for his declamations on the damage that Young had done with the "Night Thoughts"; ${ }^{5}$ and, finally, he objects to the improper joke ${ }^{8}$ on the "Night Thoughts" in the German translation of the Frenchman Moissy's "Spiele der kleinen Thalia" (I770). ${ }^{7}$

\section{Christian Friedrich Daniel Schubart (i739-179r)}

Schubart knew Young's "Night Thoughts" intimately, altho only in translation. He writes to his brother-in-law Böckh of the books added to his library by some friends during his absence, and among them he mentions the "Night Thoughts" with special emphasis. ${ }^{8}$ In a letter to Wieland, the next year, he enumerates his demands of a poet: only that poet is really great, who uses his talents to promote virtue and religion. Among the modern poets, those who have done so have been more successful by far than those who forsook the paths of virtue

1 "Ossian in Germany." R. Tombo, Jr., Columbia University Germanic Studies. Vol. I, No. 2. New York, I901, pp. 105-II9.

2 "Deutsche Litteraturdenkmale." Vol. XXIX, pp. I71-175.

${ }^{3}$ Cf. ibid., Vol. CXXVIII.

${ }^{4}$ Cf. ibid., p. 268; also supra, p. 87.

${ }^{5}$ Cf. ibid., pp. 338-339.

- This joke still circulates in America. Frequently to the present day, book agents, more ambitious than scrupulous, have sold Young's "Night Thoughts" to ignorant, unsuspecting readers as an obscene work.

${ }^{7}$ Cf. "Deutsche Litteraturdenkmale," l.c. p. 393.

${ }^{8}$ Letter, dated Aalen, July 23, 1763 . Cf. "Schubart's Leben in seinen Briefen." Strauss. Berlin, I849. Vol. I, pp. 28-29. 
and religion. Such successful poets are Milton, Klopstock, Young, and Wieland. ${ }^{1}$

Young's moralizing philosophy and depth of thought found a responsive chord in Schubart's fantastic, mystic nature and exerted a great influence upon his poetry. Further, he is in sympathy with the imitators of Young. He writes to Haug $\left(\mathrm{I} 76_{3}\right)^{2}$ that he is tired of all the parodies on the "Christian in Solitude" and is glad to see something new. The poems of Schubart that especially show influence of Young are the songs of death, "Todesgesänge," published in 1767 . Here and in others we find many thoughts of death and the grave, time and immortality, and other themes of Young.

\section{KARL LUDWIG KNeBeL ( $1744-1834)$}

Knebel's biographer tells us that the poet in his youth was saved from the abyss of doubt and uncertainty by the "Night Thoughts," which had been recommended to him by his brother. Young held him spellbound for a considerable period, and Knebel continued to devour the "Night Thoughts" up to the time when he entered the University of Halle; and he was inclined, as a result of this reading, to the study of theology. ${ }^{3}$

Much of Knebel's poetry is of a serious vein, nature poetry, which shows the influence of Thomson. Schiller's philosophy is also unmistakable, and such poems as the "Hymnus an die Sonne," "Hymnus an die Erde," "Hymnus an den Geist der Erde," are suggestive of Young's rhetorical style, ending in a memento mori as the poet turns to thoughts of the grave and of the life hereafter.

\section{Jakob Michael Reinhold Lenz (I751-I792)}

The great influence that Young had upon Lenz has been admirably sketched by Anwand in his recent contribution to

1 Cf. "Schubart's Leben in seinen Briefen." Strauss. Berlin, I849. Vol. I, pp. 54-55.

${ }_{2}^{2}$ Letter, dated Aalen, July I $_{5}$, I $_{7} 6_{3}$. He refers to Crugot's "Einsamkeit." Cf. supra, p. 93.

3 "K. L. Knebel's Leben von Th. Mundt," in Knebel's "Nachlass." Leipzig, I835, pp. xi, xiii. 
the study of the poems of Lenz. ${ }^{1}$ The author shows how the natural hypochondriacal tendency of Lenz's youth was increased by the reading of the "Night Thoughts." The verbal resemblances are very few and vague, but the themes in general are entirely under the spell of the "Complaint," and prove how thoroly the German poet imbibed the philosophy of the English bard. Death is the teacher of life for both poets, the redeemer to be welcomed, not feared.

Altho not so evident at first glance, Lenz nevertheless occupies a position similar to that of Young as moral preacher, admonishing to repentance before it is too late; and he, too, invokes the muse to sing of dark trials and tribulations. Both poets depict the misery of unfortunate mortals, war, famine, pestilence, and conflagration. The "Satires" appear to have furnished Lenz with some of his sentiments. If Young seems to be present in the Nachtschwärmerey, it is thru the medium of Klopstock. Goethe and Rousseau are also sources. ${ }^{2}$

\section{Johann Heinrich Jung-STiLing (1740-18I7)}

Jung-Stilling was an ardent admirer of Young's "Night Thoughts." In his autobiography he speaks of reading Milton's "Paradise Lost," Young's "Night Thoughts," and Klopstock's "Messias," and calls them three books which harmonized perfectly with his soul. His former sanguinely tender temperament had given place, he says, to mild, tender melancholy, which would very likely remain with him until death. ${ }^{3}$ At all events, his love for Young remained; for, in 1793 , he advises Sophie von La Roche to read Young's "Night Thoughts on Time" as the best book in time of grief." Stilling's extreme piety pervades his work, and his material has much in common with Young; but having the same biblical sources, being a

\footnotetext{
1 "Beiträge zum Studium der Gedichte von J. M. R. Lenz." O. Anwand. München, pp. 52-63.

${ }^{2}$ Cf. ibid., p. 105.

3 "Sämmtliche Werke." Stuttgart, r835. Vol. I, p. $24 \mathrm{r}$.

4 Euphorion. 1895. Vol. II, p. 585. R. Hassencamp: "Brief von J. H. Jung-Stilling an Sophie von La Roche," dated Marburg, Nov. 27, I793. Her daughter had died a short time before.
} 
student of Milton and Klopstock, as well as of Young, he was exposed to similar influences from these different sources, and it is impossible to demonstrate influence of the "Night Thoughts."

\section{Jean Paul Friedrich Richter ( $1763-1825$ )}

Jean Paul was a student of Young and found much in this kindred spirit to admire. The Prince of Gotha presented him in I80I with a de luxe edition of the "Night Thoughts," which he calls divine (englisch). ${ }^{1}$ He mentions Young frequently in his works; but one can hardly speak of real imitation, altho many thoughts and themes are found in Jean Paul that have parallels in Young, as has been pointed out by Barnstorff. Further, Müller claims that the reading of Young, Pope, Gellert, etc., inspired the essay "Etwas über den Menschen" (I 78I). ${ }^{2}$ There is a warmth in Jean Paul, however, and a direct simplicity that touches our hearts more effectively than Young ever does.

Altho an admirer of the author of the "Night Thoughts," Richter was not blind to his faults and especially those of his imitators. He even satirizes himself among them, as it were: "Beim Himmel! Wir versalzen uns da Alle mit Nachtgedanken den heiligen Abend ohne Noth, und es weiss Keiner von uns, warum er so seufzt.".3

That he was not in sympathy with these tearful poets is proved decidedly in his "Lob der Dummheit." $\mathrm{He}$ calls them the poets who live on tears as the fish on water. They are snow men, who, contrary to the course of nature, are stiffened by the frost, but at night are melted by the moonbeams. In the second Deluge, the one of tears that these poets lately caused in Germany, they proved themselves zealous as frogs thru their voices, as fish thru their gills. But, he concludes, it is not necessary to say much about them now, since they disappeared with the water. ${ }^{4}$

${ }^{1}$ Letter to Ch. O. Meiningen, Nov. 2r, 180r. Cf. also "Werke" in Kürschner's "D. N. L." Nerrlich. Vol. I, p. xlviii.

${ }^{2}$ Euphorion. Vol. VI, p. ${ }^{6} 67$.

3 "Werke." Hempel. Vol. IX, p. 474. " 4 "D. N. L." l.c. p. I6o. 


\section{Johann Christoph Friedrich Hölderlin (1770-1843)}

Ebert's translation of the "Night Thoughts" furnished food for Hölderlin's thoughts on the transitory splendors of earthly life. In his poem "Der Lorbeer" (1788) the youth pays a tribute to his ideal, and from that time on this life offers less and less to this melancholy poet. But Young was soon replaced by Klopstock, who offered as much peace to Hölderlin's desire to quit this sphere and yet filled his soul with sublime, rather than morose, melancholy. ${ }^{1}$

\section{FRIEDRICH VON HARDENBERG (Novalis) (I772-I80I)}

Altho Novalis's "Hymnen an die Nacht" (I797-r 198) do not resemble or show influence of Young's "Night Thoughts," they must be mentioned, because critics until recently have claimed such influence. ${ }^{2}$ They were misled to this conception by a passage in Novalis's journal, which reads, "Abends. in Young's Nachtgedanken geblättert." 3 It is very probable: that the "Night Thoughts" had some influence in the choiceof subject, or they may even have suggested the idea of giving. vent to his grief in writing, for the cause was the same in both cases; but here the resemblance ends. Barnstorff cites Wörner's interpretation of an obscure passage in the third Hymn thru a similar thought in the "Night Thoughts," and this is the sum total of definite parallels."

\footnotetext{
1 Cf. "Die Jugenddichtung Friedrich Hölderlins." Rudolf Grosch. Berlin, I899, pp. IO-II.

${ }^{2}$ Just Bing, in his biographical sketch of Novalis, Hamburg und Leipzig, I893, p. II 3 , voices the same opinion.

3 "Novalis Schriften," Ernst Heilbronn. Berlin. Igor. Vol. I, p. 268.

4 Cf. Roman Wörner: "Novalis' Hymnen an die Nacht und geistliche Lieder." München, 1885, p. I6. The passages are: Novalis - "und mit einemmale riss das Band der Geburt des Lichtes Fessel." Cf. Young, Night I, verses $13{ }^{1-1} 33:-$

"Embryos we must be, till we burst the shell, Yon ambient azure shell, and spring to life, The life of gods (O Transport!), and of man."
} 
(g) Minor Works of Minor Writers that show or suggest Influence of the "Night Thoughts"

H. C. Kretsch (1725-178r). "Klagegedichte." I753. An elegy treating of the vanity of earthly life, the fickleness of fame, and other themes that are favorites of Young.'

J. F. Löwen (1729-1771). "Der Christ bey den Gräbern." Hamburg, I753.

Anonymous. "Klage bey dem Tode der Geliebten." Altenburg, 1753 .

C. W. C. Fr. v. C. "Betrachtungen über Leib, Seele, Tod und Leben." Bresslau, I754.

Anonymous. "Der Christ auf dem Sterbebette." I754. Contains citations from the "Night Thoughts" and treats of similar subjects. ${ }^{2}$

F. E. Natho (1736-1806). "Der Tod des Christen."

Ph. L. S. Müller, Professor zu Erlangen. "Einsame Nachtgedanken, eine Wochenschrift oder moralische Betrachtungen über die Welt und Weltliche Begebenheiten." Wien und Leipzig, $\mathrm{I} 76 \mathrm{r}^{3}$

Anonymous. "Nachtgedanken bey einer gefährlichen Reise in Kriegeszeiten, vom Verfasser des Christen im Kriege." Bresslau, bey Meyer, I762.4

Anonymous. "Stunden der Einsamkeit." Leipzig, $1760 .{ }^{5}$

Anonymous. "Scherze der Lyrischen Muse." Leipzig, I760. Even this contains night thoughts with direct reference to Young, Hervey, and Zachariae as typical nightly bards. ${ }^{\circ}$

Anonymous. "Mein Vergnügen in Zürich." Halle. This contains a series of complaints in Young's manner. ${ }^{7}$

${ }^{1}$ In "Anthologie der Deutschen," Ch. H. Schmid. Frankfurt und Leipzig, I 770, Part I, pp. 314 ff.

${ }^{2}$ In "Schlesische Sammlung kleiner auserlesener Schriften," etc., Part III. Breslau und Leipzig, I 756, XXX, pp. 477-492.

${ }^{3}$ Harshly reviewed in Briefe, die neueste Litteratur betreffend, 176r. 182d "Brief," pp. 59-64.

4 Likewise harshly reviewed, ibid., p. 69.

"Ridiculed, ibid., I83d "Brief," pp. 73 ff.

- Likewise ridiculed, ibid., p. 78.

7 This, too, is ridiculed, ibid., pp. $8 \mathrm{I}$ ff. 
M. K. Curtius (I724-I8O2), Professor der Ritterakademie zu Lüneburg. "Kritische Abhandlungen und Gedichte." Hannover, I760. Many poems contain mention of Young and follow in his footsteps. Cf. especially "Abhandlung von dem Erhabenen in der Dichtkunst," p. 38; "Die Weser," p. 160; "Die Schicksale der Dichtkunst," p. I80.

"Der Einsame." Hamburg, I766. A moral weekly containing articles on solitude and the like, strongly influenced by the "Night Thoughts," which are frequently cited. Cf. especially, Part I, "Des Einsamen Bewegungsgründe die Einsamkeit zu suchen. Nutzen der Einsamkeit," pp. 3-8; "Vortheile der Einsamkeit in Ansehung der Religion," pp. I93-200; Part II, "Von der pflichtmässigen Verläugnung der Menschen, in Ansehung ihres Aufenthaltes auf Erden," pp. 89-96.

$\mathrm{Ph}$. E. Kern (I7I6-I777). "Triumph vor dem TodtenBette." Hildburgshausen, I764. This bears Young's name on the title-page and breathes the spirit of the author of the "Night Thoughts" in the treatment of Christian subjects. ${ }^{1}$

A. G. Hering. "Über den Tod der Mutter." "Über den Tod eines Bruders." Two complaints in the tone of Young's "Night Thoughts." 2

Schilling. "Gedichte." Bremen, I772. Many traits betray influence of the "Night Thoughts," especially in "Die Leiden einer jungen Muse." Bremen, I769.

"Gesellschaftliche Bemühungen der Welt die christliche Religion anzupreisen :-

Kein Licht, kein Trost erfreute mich,

Kennt' ich nicht, Jesus Christus, dich."

Vol. I, Stück I. Göttingen und Gotha, I772. I98 pp. Zealous arguments to prove the immortality of the soul in Young's manner, citing the "Night Thoughts" for proof."

${ }^{1}$ Review: Auszüge und Urtheile über die neuesten Schriften aus den schönen Wissenschaften. Gotha, 1765, pp. 376-383. Unfavorable criticism that points out the fact that Kern is an admirer and imitator of Young. Against this criticism appeared the review in Ausführliche und kritische Nachrichten über die besten und merkwürdigsten Schriften unsrer Zeit, etc. 1765, pp. 105-128.

"In "Anthologie der Deutschen," Ch. H.. Schmid. Frankfurt und Leipzig, I770, Part I, pp. 35-46.

${ }^{3}$ Review in Frankfurter Gelehrte Anzeigen vom Jahre, 1772. Reprint in 
A. H. Heydenreich, C. S. Regierungs-Rathe. "Das Grab in Vier Gesängen." Coburg, I775. A poem of forty pages on the grave and death, imbued with Young's spirit and borrowing largely from the "Night Thoughts." In fact, the resemblance is so strong that the poem was bound with the Schaffhausen edition of Ebert's translation of the "Satires."

J. K. Wetzel (I747-I8I9). "Epistel an die deutschen Dichter." Leipzig, I 775. "Die unvermuthete Nachbarschaft. Ein Gespräch," pp. 25-48. An imaginary conversation between Young and Sterne, characterizing both writers. Young is represented as the pessimistic moralizer, Sterne as the jovial satirist.

K. Ph. Moritz ( $1757-\mathrm{I} 793)$. In his psychological novel "Anton Reiser" ( $1785^{-1790), ~ M o r i t z ~ s h o w s ~ t h e ~ w a r m t h ~ o f ~}$ his admiration for the "Night Thoughts," when the hero, avowedly the author himself, says that it seemed to him as if he found in the work of Young all his former ideas on the emptiness of life and the vanity of all earthly things. He could not read the work sufficiently to satisfy himself, and he learned the leading thoughts and sentiments by heart. ${ }^{1}$

G. F. Stäudlin (r758-r796). The poem "An die Schwermuth" shows the influence of Young's "Night Thoughts." 2

F. L. Fischbach. "Nächtliche Einsamkeit zum Gebrauch für jeden Menschen, der Vernunft hat." Stettin, I78r. The whole work, I84 pp., is written in language similar to Young's; there are similar thoughts, arguments, and figures, with the same irrelevant digressions that are typical of the "Night Thoughts." Night is invoked for inspiration and eulogized in Young's manner.

F. T. Wettengel (I750-1824). "Trostgründe bey den Gräbern unsrer Geliebten." Greiz, I785.

The above-cited works are a few typical examples of the scores of imitations that sprang into existence like mushrooms

\footnotetext{
“Deutsche Litteraturdenkmale des 18. und I9. Jahrhunderts." Vol. CXXX, pp. $332-338$.

1 Cf. "Deutsche Litteraturdenkmale des I8. und I9. Jahrhunderts." Vol. XXIII, Part III, p. 227.

${ }^{2}$ Cf. Weltrich's Schiller. Vol. I, p. 487.
} 
over night. Goedeke's "Grundriss," Vol. VII, gives the titles of innumerable works by ephemeral poets that suggest Young, but the works are utterly forgotten now and, as a rule, can not be obtained in any of the leading German libraries. Besides these, nearly all the Moralische Wochenschriften from I750 to 1800 contain references to Young, as well as articles that show the influence of the "Night Thoughts." It would take us too far afield, however, to treat all this ephemeral literature.

In Austria the movement lasted somewhat longer, as it had also developed more slowly, and after 1800 we find numerous unimportant poems and works by minor writers that suggest influence of the "Night Thoughts." Such poets as Glatz, Veillodter, Theremin, etc., etc., ${ }^{1}$ seem to stand under the shadow of Young. Most of these minor works it was impossible to locate, so no detailed résumé can be given.

\section{(h) The Classical Writers and the Reaction against the "Night Thoughts"}

\section{Christoph Martin Wieland ( $1733-181_{3}$ )}

Wieland, in his earlier years, nourished his already overzealous and somber piety thru the study of Klopstock and Young, so that he rejected all poetry that was not written in Klopstock's idealistic vein, and accused of indifference to religion all who did not prefer the meanest hymn to the most charming anacreontic of $\mathrm{Uz}^{2}$

His first acquaintance with the "Night Thoughts" must have been in German translation; for at the time when he began to learn English, March, I752, he already shows great fondness for the work. ${ }^{3} \mathrm{He}$ is prepared to love Bodmer's Crito for its review of the "Night Thoughts," " and a little

'Cf. Goedeke's "Grundriss," Vol. VII.

2 "Geschichte der deutschen Nationallitteratur," Koberstein. Vol. III, p. IIg.

3 "Ausgewählte Briefe." Zürich, I8I5. Vol. I, p. 55, letter to Schinz, Tübingen, March 26, 1752. He burns with the desire to read Milton, Pope, Addison, Young, and Thomson in the original, he writes.

${ }^{4}$ Cf. ibid., p. 256, letter to Bodmer, Tübingen, Jan. I9, $175^{2}$. 
later he writes in the tenderest terms to Schinz about the latter's review and is anxious to know whether the satires entitled "The Love of Fame" are really by Young. " Other letters evince the same unbounded admiration for this author, who "rises to the plane of the very angels." 2

But two years later a complete reaction, largely caused by his associations with Zimmermann, has taken place in Wieland. The former disciple of Young now considers that author's poetical taste bad and capable of corrupting the taste of young writers. There was a time, he says, when Young charmed him; but that time is past. ${ }^{3}$ And Wieland was cured forever. Fifteen years later, writing about the Ossianic bards, he urges the necessity of taking a whip to the Klopstocks and their imitators and the transcendental poetical fools. ${ }^{4}$ Thus the period of Wieland's life that may be regarded as subject to influence from Young falls between the years $\mathrm{I}_{75} \mathrm{I}$ and $\mathrm{I}_{758}$. Ebert cites no less than forty-three passages that show this influence. The works especially to be considered here are: "Briefe von Verstorbenen an hinterlassene Freunde" (I753), "Sympathieen" (I754), "Empfindungen eines Christen" (I757), and there is no doubt a striking resemblance and abundant influence.

\section{Gotthold EpHram Lessing (I729-I78I)}

Lessing's acquaintance with Young's "Conjectures" and his relations to them have already been discussed. ${ }^{5}$ His reviews also prove his acquaintance with other works of Young and especially with the "Night Thoughts." " His review of Kayser's translation, in I753, calls the "Night Thoughts" "this masterpiece of one of the sublimest poets." 7 Altho he must find fault with the hexameters, he feels that the translator deserves commendation for helping to spread the original. He hopes the translation will be continued so as to include all the Nights, and he cites the biographical data on Young with an interest

1 Cf. “Ausgewählte Briefe." Zürich, I8I5. Vol. I, p. 59.

${ }^{2}$ Cf. ibid., p. 22 I.

${ }^{3}$ Ibid., l.c. pp. 269-270.

${ }^{4}$ Cf. ibid., Vol. III, p. I34.

'Lessing's "Sämmtliche Werke." Lachmann-Muncker edition. Vol. VIII, pp. 79, I25; Vol. IX, p. 336.

${ }^{7}$ Cf. Bibliography, infra, I752. 
that is significant. At this time Lessing was studying English poets, Pope, especially, in addition to Young. Klopstock, too, occupied him; but that his endurance of such poetry was limited, Lessing shows in the couplet:-

"Wer wird nicht einen Klopstock loben?

Doch wird ihn jeder lesen? - Nein." (I75I) ${ }^{2}$

And yet Lessing read him and tried his own poetical talents in serious verses on human happiness and religion. His fragment, first published in 1748 , "Aus einem Gedichte über die menschliche Glückseligkeit," ${ }^{2}$ shows this tendency, which is further developed in the fragment "Die Religion," published in $175 \mathrm{I}^{3}$ Like Young, he chooses the quiet hours of night to concentrate his soul, 4 and, overcome by the thought of the nothingness of man compared with the infinite God, he calls out in Young's words, "Was ist der Mensch?" 5 The arguments thruout the fragment suggest Young strongly.

Lessing did not remain in this mood long, and we find him writing anacreontics soon after. His admiration for Young cooled as he grew older, but he did not turn against him, as is sometimes said. ${ }^{\circ}$ His review (1759) of Cramer's periodical Der Nordische Aufseher, ${ }^{7}$ in which the latter considers Young sublimer than Milton and second only to David and the Prophets, calls this fanatical adoration "somewhat exaggerated" (etwas übertrieben); but that is not a harsh rebuff. That Lessing shared the views of his fellow-critics who, in the Litteraturbriefe, waged war against the Nachtgedankenmacher, is a safe conjecture; but this, too, is directed against the hosts of imitators of Young, not against Young himself.

\section{JoHANN GotTrRIEd HERdER (I 744-I803)}

Herder, whose life-long admiration for the "Conjectures" has been discussed," was a zealous student of the "Night

\footnotetext{
1 "Sämmtliche Werke," l.c. Vol. I, p. 2. " Cf. verses 23-24, ibid., p. 257.

2 Cf. ibid., pp. 237-240.

3 Cf. ibid., pp. 255-267.

${ }^{3}$ Cf. verse 47 , ibid., p. 258.

Cf.

${ }^{7}$ Cf. on Cramer, supra, pp. 63, 83-84; also, Bibliography, infra, 1758 .

Cf. supra, pp. 40-57.
} 
Thoughts," as is evinced by the innumerable discussions in his reviews, writings, sermons, and letters. He himself had many points in common with Young, and his sermons, naturally dealing with the same problems that are found in the "Night Thoughts," were especially open to influence from that source. He translated a considerable portion, I25 verses, of Night I, some verses of Night II, and published 66 verses of the opening of Night V, a translation by G. W. Oeder, besides using several citations from the original or from Ebert's translation for various purposes of criticism. ${ }^{1}$ But in spite of his eager study of the "Night Thoughts" and the warm attitude that he shows toward them, he was by no means blind to their faults.

As early as 1772 , he calls Young the foremost of all gloomy poets, but finds fault with the chaos of thoughts and figures, and admits that they must often cause headache and exasperation. ${ }^{2}$ He also prophesies of the imitators of Young and Hervey, that such gloomy singers must finally become the most distasteful and miserable of poets, "the most croaking raven of Herrnhutisch death melodies." Elsewhere he speaks of these imitators as "schlechte Schmierer von Nachtgedanken." 3 Other passages give full proof of the fact that Herder, with his sharp eye for literary merit, was fully aware of Young's weaknesses.

$\mathrm{He}$ reaches the height of his reaction against the "Night Thoughts" in the following statement. Having given as his opinion that Young could not attain the standard of Milton, Herder says: "Young . . . who wished at all costs to be an original, vied with Shakspere, Milton, Pope, and all the didactic poets of the world. . . A A bold wish to be an original, with which he, however, finally produced nothing more than sermons, no matter whether he called them Night Thoughts, Odes, Satires, or Tragedies. His greatest and favorite figure in the 'Night Thoughts' is the parenthyrus (hyperbole), which, to be sure, heaps one tirade of wit upon the other and says many beautiful things, but as a result does nothing further than to force (schrauben) the human understanding

${ }^{3}$ Cf. Bibliography, infra, 1803 .

2 "Sämmtliche Werke," Suphan edition. Vol. V, pp. 290-29r.

${ }^{3}$ Cf. ibid., Vol. I, p. 253. 
above its natural level. I am surprised that Young was ever considered a deep thinker; he is on all sides an extremely witty, hyperbolical poet, striving for originality. Rich in thoughts and figures, he did not know how to control them. As he studied English theology in Thomas Aquinas, upon the malicious advice of Pope, ${ }^{1}$ he likewise would have studied it in the Koran. Few poets are, therefore, to be read with so much caution. In his 'Night Thoughts,' as the name implies, he is to be tested as a thinker, and every coquetry of wit is to be esteemed for what it is, even if it concerns the holiest things." ${ }^{2}$

But this is not Herder's final judgment; at least, it contains no malice, and he gives as his last estimate the following characteristic: "Young's 'Night Thoughts,' finally, are the non plus ultra of sententious, witty, sublime, pious thoughts, brilliant as the nightly firmament; who can arrange and count them?" 3

\section{Johann Wolfgang Goethe (1749-1832)}

In 1766 , Goethe wrote to his sister from Leipzig about his learning English from Milton and Young. ${ }^{4}$ A letter to his grandmother from Strassburg, in I77I, upon the death of his grandfather, contains thoughts that remind one of Young, and a letter the same year to Salzmann speaks of grasping after phantoms, in words that resemble Night I, verse 202.5 Other letters contain similar philosophy that shows the youthful Goethe still busy with the "Night Thoughts," whether for the purpose of learning English or for the poem itself.

That "Werther," which appeared soon after, contains a view of the philosophy of life and death similar to that found

1 This refers to the curious anecdote, related by Ruffhead, of Young having been persuaded by Pope to study the writings of Thomas Aquinas as the best course of preparation to be pursued by a candidate for holy orders in the Church of England. Cf. Young's, "Complete Works," edited by Doran. London, I854, Vol. II, p. 559, note.

2 "Sämmtliche Werke," Suphan edition. Vol. XVIII, p. Io6.

3 Cf. ibid., Vol. XXIII, p. 236. "Adrastea," r80r.

" "Goethes Briefe," Weimar edition, 1887. Vol. I, p. 7 I.

'Cf. ibid., pp. 254, 263. Cited by S. Wukadinovic. Euphorion. Vol. V, p. $14 \mathrm{r}$. 
expressed in the "Night Thoughts," is therefore not astonishing. Barnstorff cites a number of interesting similarities. ${ }^{1}$ In the Thirteenth Book of his autobiography, Goethe characterizes the effect that the gloomy English poets had upon Germany at that time, and attributes to them, mentioning the "Night Thoughts" as the work in which the pessimistic weariness of life is preëminently worked out, the conditions that caused "Werther" to strike a responsive chord everywhere. ${ }^{2}$ But Goethe, having delivered himself of this melancholy burden in his "Werther," was cured, and henceforth the "Night Thoughts" had no more attraction for him; whereas his fellowcountrymen continued in their melancholy. Barnstorff cites the French imitation "Wertherie," Paris, I79I, where the catastrophe is developed by a passage read from the "Night Thoughts." 3

During Goethe's sentimental period, as sketched above, a poem of 60 verses appeared in Hamburg, entitled "Eine Elegie von Herrn Doct. Göthe." " The anonymous author, certainly not Goethe, makes free use of Young's "Night Thoughts," especially of Nights III and IX. Finally, Goethe's humor on this subject, as displayed in his verses "Das Alter," might be added :-

\author{
"Das Alter ist ein höflich Mann, \\ Ein Mal übers andere klopft er an, \\ Aber nun sagt Niemand: herein! \\ Und vor der Thür will er nicht sein. \\ Da klinkt er auf, tritt ein so schnell, \\ Und nun heisst's, er sei ein grober Gesell." s
}

Karl Weinhold, in the Zeitschrift des Vereins für Volks-

1 Cf. l.c. pp. 74-75.

${ }^{2}$ When L. Geiger, in the Jahresberichte für neuere deutsche Litteraturgeschichte, Vol. III, IV 8d: I 7, criticises a similar claim made by F. Duebner in his "Quelques remarques sur "Werther," etc., he loses sight of the fact that the great reading public could be affected by the wave of English influence secondarily, and did not have to be brought directly into contact with English sources.

${ }^{3}$ Cf. l.c. p. 75 .

4 Cf. Bibliography, infra, r 774 .

'Sent in a letter to Zelter, Feb. I4, I8I4. First printed in Goethe's "Werke." Stuttgart und Tübingen, Cotta, I8I5-18I9, Vol. II, p. 286. 
kunde, ${ }^{1}$ cites these verses in connection with the couplet painted on the wall of an inn in the Ötzthal, in the Tirol: -

"Der Tod der ist ein grober Mann,

Er kommt herein und klopft nicht an."

Cf. for both, Young's "Night Thoughts," Night V, verses 618-620:-

"and death

Already at the door? He knocks, we hear him, And yet we will not hear."

\section{Johann Christoph Friedrich Schiller (I759-I805)}

During the years of his schooling in the Military Academy of the Duke Karl Eugen (1773-1780), the youthful Schiller read Young and again took up the study of Klopstock. But the influence of the latter diminished as Schiller recognized his own ability in the dramatic field, and Klopstock's religious muse became more and more foreign to him. ${ }^{2}$ Any influence of Young that might have been exerted on Schiller's poetry would very likely come thru the medium of Klopstock, and only during these early years. The poem "Der Abend" (I776) ${ }^{3}$ revels in the beauties of nature and celebrates the supremacy of the Creator in language that reminds one of Young; and the "Leichenfantasie" ( 1780$)$ "is a gloomy memento mori in which the youthful poet cries out in Young's words: "Wiedersehen himmlischer Gedanke!" s The elegy written upon the death of Weckerlin dwells upon the vanity of this transitory life, in thoughts that reflect Young. ${ }^{\circ}$

Schiller's adieu, as it were, is said to Klopstock and his school in the Anthology of $1782,{ }^{7}$ in the couplet entitled "Messiade" :-

"Religion beschenkte diss Gedicht,

Auch umgekehrt? - Das fragt mich nicht."

${ }^{1}$ Cf. ibid., Vol. VI, p. 2 Ir.

2 "Friedrich Schiller," Richard Weltrich. Stuttgart, I899. Vol. I. p. 236.

3 "Schillers sämmtliche Schriften," Goedeke. Stuttgart, 1867. Vol. I, pp. 27-30.

${ }^{4}$ Cf. ibid., pp. 106-108.

- Cf. ibid., p. 108, verse 64 .

Cf. ibid., pp. 178-183.

7 Cf. ibid., p. 265. 
Later in life, having outgrown these youthful tendencies, Schiller, in his essay on "Naïve and Sentimental Poetry" (I795-I800), mentions Young among the satirists of pathos, who were directed into this channel by their period of degeneracy. ${ }^{1}$ In the same essay, where he treats of elegiac poetry, he reveals his complete recovery from all sympathy with the tendencies of Klopstock and Young as follows: "No poet with possibly the exception of Young, who in this respect demands even more than Klopstock, without, however, giving us as much in return, - no poet could be less adapted than Klopstock to serve as one's favorite author and guide thru life; because he always leads us away from real life, always engages only our souls, without refreshing our minds with the calm presence of anything material. Chaste with nothing of the earthly, immaterial, as holy as his religion, is his muse, and one is forced to wonder that he, altho he often loses his way in these lofty heights, never falls from them. I, therefore, sincerely confess that I have some fears for the intelligence of those who in all sincerity and without affectation choose him for their favorite poet." 2

When W. Waiblinger (1804-1830), himself a hyper-sentimental nature, friend of Hölderlin and follower of Byron, pronounced Schiller "a species of Young, in whom chaos rules," 3 he can not mean influence of Young, but that rhetorical loftiness in Schiller's poetry, that sublime, ethereal, ideal philosophy of life that rises above the imagination of the ordinary man; and so far he is correct. This similarity exists. It is interesting to note further that the same criticism was passed by Wieland, after he had been cured of his sentimental "Youngizing," in I 789, when he refused to call "Die Künstler" a poem, but pronounced it "philosophical poetry of the species of Young's 'Night Thoughts.' ", 4

${ }^{1}$ Cf. "Schiller's sämmtliche Schriften," Goedeke. Vol. X, p. 459.

${ }^{2}$ Ibid., Vol. X, pp. 473-474.

${ }^{3}$ Cf. "Goethe Jahrbuch." Vol. XII, p. 320. Letter to Wurm, March 5, I82r. Cited by S. Wukadinovic. Euphorion. Vol. V, p. r4r.

'Cf. Schiller's letter to Körner, Weimar, Feb. 25, I789, in "Schillers Briefe," Jonas. Vol. II, p. 236. 


\section{JUSTUS MÖSER (I720-I794)}

In his "Schreiben einer Dame an ihren Capellan über den Gebrauch ihrer Zeit," Möser allows his lady to say that the "Night Thoughts" cause her most violent headaches the moment she begins to read them. ${ }^{1}$ In another writing, on the removal of cemeteries, he connects Young's name with the expression, "The melancholy muse can croak only a funeral carmen." " In his "Harlekin" 3 he also mentions Young three times and always with a satirical turn. The spirit of the whole book is opposed to melancholy and seriousness; and a contemporary critic even went so far, at the time of its appearance, as to see in it a satire directed against the gloomy "Night Thoughts." "

\section{Johann Benjamin Michaelis (I746-1772)}

Michaelis told a confidential friend that the craze of his fellowcountrymen to imitate English writers, and the fever to translate certain authors, had for a long time filled him with satirical wrath. ${ }^{5} \mathrm{He}$ expresses this wrath against the wave of "Youngizing" that had deluged Germany, in his second satire, as follows:-

"Empfindungen, Bardiet, Theater, Reverien,

Fragment, Bibliothek, Einfälle, Rhapsodien,

Museum, Wälder, Brief, Anthologie, Versuch: ${ }^{\circ}$

Aus diesem nimm ein Wort, und setz' es vor ein Buch;

Wenn dann vor seiner Stirn ein englisch Motto schmettert,

So wird dein Werk verlegt, bezahlt, gekauft, vergöttert." ?

1 "Sämmtliche Werke." Berlin und Stettin, r798, Vol. I, p. 28r.

"Cf. ibid., Vol. IV, p. 179.

3 "Harlekin oder die Vertheidigung des Groteske-Komischen." I76r, 80 pp.

Cf. "Werke," l.c. Vol. VII, pp. 70-II5.

4 Thomas Abbt's Letter to Mendelssohn, Rinteln, Oct. I3, r76r.

s “Sämmtliche Poetische Werke." Wien, r79I, Part I, Preface, p. I03.

- Earlier editions had:-

"Gedanken, Possen, Trost, Empfindung, Magazine,

Sammlung, Bibliothek, Einfälle, kom'sche Bühne,

Scherz, Klagen, Zeitvertreib, Zerstreuungen, Versuch:"

' Cf. "Sämmtliche Poetische Werke," l.c. p. I I2. 
His disgust is also shown in the following verses:-

"Die Deutschen wollen nicht, sie können alles seyn;

Allein sie bleiben stets, in andrer Werth verloren,

Nachahmende Genies, originelle Thoren.

Zehn plappern närrisch nach, was einer weislich sprach.

So bald ein Deutscher denkt, schwärmt auch ein Deutscher nach;

Und wer am meisten gilt, erhält von Zeit und Mode

Lied, Epopee, Idyll, Erzählung, Fabel, Ode." 1

This is aimed directly against imitation of Young in this couplet: -

"Young klagt - kein Jüngling ist, der nicht sogleich sich härmt,

Von Gräbern etwas lallt, vom Sterben etwas schwärmt." 2

And finally, in his verses "Liebe und Hass," he again satirizes the imitation of Young:-

"Young klagt - Dorinden schmäht Amynt;

Gleim scherzt - Dorinden lobt Philint:

Bey Mädchen und der Welt kommt's auf die Seite an,

Von der wir sie zum ersten Mahle sahn." s

\section{HEINRICH LEOPOLD WAGNER (1747-1779)}

In the tragedy "Die Kindermörderin," Young's "Night Thoughts" in French translation are said to be the heroine's favorite book in her ever increasing melancholy. To this von Hasenpoth replies: "God be merciful unto her! - If I had to read a single page of it, I should play the Englishman, and hang myself with my garter." A A sentiment that was very likely Wagner's own.

1 Cf. "Sämmtliche Poetische Werke," l.c. p. Ir3.

${ }^{2}$ Cf. ibid., p. Ir6.

${ }^{3}$ Cf. ibid., l.c. p. 177 .

- This passage was omitted in K. G. Lessing's revision, as has been pointed out by E. Schmidt. Cf. "Deutsche Litteraturdenkmale des r8. und r9. Jahrhunderts." Vol. XIII, p. vii. Cf. also S. Wukadinovic, in Euphorion. Vol. V, p. I4I. 


\section{JohanN Jakob WiLhelm Heinse (I749-1803)}

In a letter to Gleim ( $\mathrm{I} 77^{2}$ ) Heinse says that the former's poem on the existence of God, "Das Daseyn Gottes," ${ }^{1}$ is dearer and of more value to him than all the Youngish, Senecan, Platonic, and Herrnhutherischer nonsense on the Being of Beings. ${ }^{2}$ This is a corroboration of the attitude in an earlier poem ( 1766 ), entitled "Empfindungen in einem entzückenden Thal' im May I766, niedergeschrieben von einem Jünglinge, der noch ein Knabe war." After 54 anacreontic verses, full of exuberant outbursts over the joy of living, he exclaims:-

"Young und Plato eurer Schwärmerey

Stimmet man nur mit dem Munde bey!"

Thoughts of death and of the grave creep over him in his sentimentally happy mood, but he dispels them and thinks only of the pleasures of earthly life. ${ }^{3}$

\section{JoHANN GeORg JACOBI (I740-I8I4)}

Jacobi occupies a peculiar position in reference to the "Night Thoughts"; an admirer of Young himself, he nevertheless could not tolerate Young's innumerable imitators. Quite the opposite of the serious Young, Jacobi, in his light, bantering, satirical tone, was, however, capable of serious thoughts of the grave and death, as is shown especially in the last stanza of his poem "Klage" :-

\section{"Willkommen, kalter Schauer! \\ Du Nachtgeflüster du! \\ Willkommen meiner Trauer! \\ Im Grabe nur ist Ruh.” ‘}

In his poem "An Betty" there is a hidden thrust at the theme of nightly visions, when he chides Betty for her recent gloom,

1 "Lieder für das Volk," I 772. In "Sämmtliche Werke." Vol. I, p. $35^{8}$.

"Quellenschriften zur neuen Litteratur- und Geistesgeschichte. Vol. II : "Briefwechsel zwischen Gleim und Heinse." Schüddekopf. Weimar, 1894, p. 82 .

"Cf. ibid., "Anhang," pp. 254-258.

" "Sämmtliche Werke." Zürich, 1825. Vol. II, p. 367. 
and cautions her that if she continues she will have visions and see

... "lauter Gräber . . .

Und zwischen Knochenhäusern gehn.

Einher auf Leichensteinen kriechen

Und ihre Todtendüfte riechen." 1

But it is in his "Nachtgedanken" ${ }^{2}$ and the poem "Die Dichter," a satirical opera played in the nether regions, that Jacobi has expressed himself most freely. Critics have called Jacobi's "Nachtgedanken" a parody on the "Night Thoughts" of Young, as the title suggests and even a first reading might seem to show; but the note to the first Night, added by Jacobi himself, informs his readers expressly that these night thoughts are merely the capricious thoughts that occurred to him while spending the required two nights in a cell to qualify for his ecclesiastical orders. The gloomy surroundings reminded him of the "numerous unfortunate imitators of Young." The work bears no suggestion of Young's "Complaint"; in fact the first Night closes with a love poem to Belinde. The second Night, too, has nothing in common with Young. ${ }^{3}$

Jacobi's epistle to Klotz ${ }^{4}$ tells how often he had scoffed at the poets of misery, who, without cause or genius, imitate worthy Young and debase his fair name. He further speaks of them as "funeral bards," and "black prophets" to stone whom would be no great loss. ${ }^{5}$ Since this "Youngizing" tendency is

1 Cf. "Sämmtliche Werke," l.c. p. I99.

${ }^{2}$ Written Jan. 7, 1769.

3 Earlier in life, Jacobi had used the title "Nachtgedanken" with a purely satirical significance. Cf. his letter to Klotz, Dec. 27, I768 (in "Briefe Deutscher Gelehrter." Hagen, I773, p. I70). He used the title "Night Thoughts" for these lines, he said, because the lines were written at midnight. Cited by G. Ransohoff: "Jacobi's Jugendwerke." Dissertation. Berlin, r892. Note, pp. 34-35.

4 Letter to Klotz. Cf. "Sämmtliche Werke." Zürich, 1825. Vol. I, pp. $278 \mathrm{ff}$.

SThese attacks upon the "nightly singers" called forth a fierce remonstrance from the pen of a certain Daneil in the Kritische Nachrichten, Lindau am Bodensee. Cf. the letter from Uz to Gleim, Sept. Ir, r769. Vol. CCVIII, p. 386 , of the "Bibliothek des litterarischen Vereins in Stuttgart." Klopstock, Herder, and others were opposed to Jacobi's bantering. Cf. Quellen und Forschungen zur Sprache und Culturgeschichte. Vol. II, pp. 9, 27. 
a thing of the past, he says, there is now a tendency to burlesque, which is also displeasing to him, since no poet of joy is tolerated. And so he hits imitation with another satirical dart.

Jacobi's best satire against the imitators of Young is in the opera "Die Dichter," the first scene of which depicts the first age of innocent, naive poetry, corrupted in the second scene by the "unwise imitators" of "wise Young." A siege of joy follows, which is relieved in the third scene, and the nocturnal spectres are allowed to depart unmolested, only a few moralists and uninvited judges of beauty remaining behind. Then the imitators of Yorick appear upon the scene, and in the fifth scene unhired bards, running loose merely for the sake of something new, try to destroy the temple of the Greek gods. ${ }^{1}$ This, too, shows a kindly attitude toward Young, ${ }^{2}$ but venom for his distasteful imitators. His preface, subsequently added, says the poem was not intended to satirize individual poets, but the prevalent craze of imitation. The lines that depict the imitators of Young's "Night Thoughts" read:-

"Die Lustgefilde waren stumm;

Die Klagen sonder Ende:

Man weinte, wusste nicht warum;" s

Friedrich von Matthisson (I76I-I83i)

Matthisson's letters, incorporated in his works as memoirs, "Erinnerungen," speak of Young in a tone that shows he was very familiar with the "Night Thoughts." 4 In 1785, he describes a hermitage, in the garden of which there were many inscriptions largely 'taken from Young. ${ }^{5}$ The next year he made the acquaintance of Ebert in Braunschweig, of whom he writes in ardent admiration, speaking of him as "der Vertraute

1 "Sämmtliche Werke." Zürich, I825. Vol. II, pp. 52-53.

${ }^{2}$ In his poem, which was later not included in his works, "Ueber die Wahrheit," Düsseldorf, I77I, Jacobi says on occasion he will weep with Young, showing here, too, his kindly feeling toward the original "Night Thoughts" poet. Cf. "Hallers Gedichte." Hirzel. Frauenfeld, I882, p. cdlxxiv.

3 "Sämmtliche Werke," l.c. p. 56.

4 "Briefe von Friedrich Matthisson." Zürich, I 795. Part I, p. 31.

${ }^{5}$ Cf. ibid., Part II, p. 24. 
Youngs." 1 Later, however, Matthisson turned to Gray, Ossian, Milton, and Klopstock, and Young does not seem to interest him. His elegiac poetry shows the influence of Gray and Ossian especially, but not of Young. That he was no admirer of extenuated complaints is seen in his poem "Stummes Dulden":-

"Feige Sterbliche nur und aberwitzige Schwärmer

Schreyn von den Dächern ihr Weh, Mitleid erbettelnd vom Volk.

Klage geziemt nicht dem Starken. . . ." 2

\section{HeINRICH WilhelM voN Kleist (I777-I8II)}

That Kleist did not share in the admiration of Young is natural, and he has left behind a tangible proof in his short essay on a picture, entitled "Empfindungen vor Friedrichs Seelandschaft." The picture, he says, lies there with its two or three mysterious objects like the Apokalypse, as if it had Young's "Night Thoughts," and since, in its monotony and lack of shore, it has nothing but the frame as foreground, it looks like a person with his eyelids cut off. ${ }^{3}$

\section{Johann Ludwig Tieck (I773-1853)}

In Tieck's novel "William Lovell," Mortimer can not find words expressive enough to assure Karl Wilmont how much he misses him. In his despair he longs to turn his ink into black songs of complaint, or to copy any passage of the "Night Thoughts." "And in the same novel the Countess Blanville says she is as sentimental as Rousseau's Julie: a little melancholy, a slight touch of Young, and a moral babbler, as tedious as the heroines of English novels. ${ }^{5}$

But a little later in life Tieck makes Young the subject of

1 "Erinnerungen." Zürich, I810. Vol. I, p. I68.

2 "Schriften." Zürich, I825. Vol. I, p. 2I5.

3 "Sämmtliche Werke." Kürschner's "D.N.L." Vol. IV, p. 289.

"Ludwig Tieck's "Schriften." Berlin, Remur, 1828. Vol. VI, Part L p. 29.

Ibid., p. 78 . 
satire, when he introduces the "Night Thoughts" in "Der gestiefelte Kater," as follows:-

$$
\text { "Prinzessin }
$$

Hier ist mein Versuch, ich habe ihn Nachtgedanken überschrieben.

$$
\text { Leander (liest) }
$$

Treflich! Geistreich!-Ach! mir ist als hör' ich die mitternächtliche Stunde Zwölf schlagen. Wann haben Sie das geschrieben?

\section{Prinzessin}

Gestern Mittag, nach dem Essen." 1

\section{Clemens Maria Brentano (I778-1842)}

That Brentano, as a representative of the Romantic School, felt no direct sympathy with Young's "Complaint," can be seen from the following verses:-
"Die Klage, sie wecket
Den Todten nicht auf,
Die Liebe nur decket
Den Vorhang Dir auf." "

1 Cf. ibid., Vol. V, Act I, Scene II, p. Igo.

2 Written in an undated letter to a relative who had just lost a child. Ca. 1800 . 


\section{CHAPTER IV}

\section{OTHER WORKS OF YOUNG IN GERMANY}

\section{I. "The Love of Fame, the Universal Passion. In Seven Characteristical Satires"}

THE story of Young's "Satires" in Germany is easily told. Unknown until many years after Pope's superior satires had found response in Germany, Young's work was eclipsed before it had fairly emerged above the horizon. Then, too, in Young's "Satires" there is so much that has only a local bearing, that they were destined to remain food chiefly for English thought of the period in which they were written. Pope was more universal; he could find response wherever man thought on man.

Altho the "Satires" were written as early as $1725-1728$, the first notice that seems to have appeared in Germany bears the date 1745 and is of the fourth edition. This review by Gottsched analyzes the first four Satires, quotes I30 verses from the original and translates them into German prose, with a résumé of the whole work. Gottsched finds the method of Young all that could be desired, and expresses a wish that his fellow-countrymen might satirize German conditions after the manner of Young. Altho Gottsched attributed these "Satires" to Glover, thus robbing Young temporarily of some fame, his review served to call attention to the work. ${ }^{1}$

By I749, Bodmer had studied the "Satires," and his Neue Critische Bricfe added to the popularity not only of the poems, but also of Young, by citing as sufficient proof of the excellence of the "Satires" the fact that they were the work of the "Author of the "Night Thoughts." 'The review translates numerous verses

1 Thruout this chapter all works that can easily be found under the given date in the Bibliography, Chapter V, are not cited in the footnotes. 
of the "Satires," probably Bodmer's own work, altho that has recently been disputed."

It is quite natural to suppose that all who read and studied the "Night Thoughts" in these years also became acquainted with the "Satires," but the extent of this familiarity, as well of the influence they had upon the minds of German readers, is very sparsely attested. Hagedorn mentions them and quotes a few verses in $175^{2},{ }^{2}$ and Gleim, Lenz, and others have left behind proof of their acquaintance with the work. In I753, a Hamburg periodical translates and paraphrases, to apply to German conditions, some 80 verses of Young's "Satires," - an endeavor to utilize them along the lines suggested by Gottsched.

The first attempt at a complete translation was made in prose ( 1755 ) by an unknown translator, who published his work in Frankfort and Leipzig and revised it the next year. Both editions, strange to say, seem to have excited no comment at the time, even upon the great inferiority of the translation. It was, however, the weakness of this rendition that inspired Ebert later to retrieve the reputation of this work of Young and to give it a place alongside the "Night Thoughts" in his zealous labors: a translation that was announced upon the title-page of the I760 annotated edition of the "Night Thoughts," but was not published until I77I. This translation of the "Satires" evinces the same care and erudition that was so evident in the new edition of the "Night Thoughts," both in the faithful reproduction of the original and in the explanatory notes, which are not so copious, however, as those to the "Night Thoughts." The original is printed on the pages opposite, as was done in the preceding volumes containing the "Night Thoughts."

The translation received favorable criticism, and Ebert was given the credit of having rescued the work from the disgrace of the previous miserable translations. Doubt was expressed by some as to the value of the notes, but on the whole the attitude of critics was very friendly. The year 1772 brought a

${ }^{1}$ Cf. "Johann Jakob Bodmer, Denkschrift zum C. C. Geburtstag." Zürich, I900, p. 34I.

${ }^{2}$ Cf. the preface to the edition of 1800 of Hagedorn's works, p. xxviii. 
new edition, without notes or English text, likewise in Braunschweig; and two years later a reprint appeared in the Schaffhausen edition, also German text only, without notes. This was again reprinted in $\mathrm{I} 777$, as Vol. IV of the Schaffhausen edition of the "Night Thoughts" and "Satires," and also separately with a new title-page. During the next year, the. r77 I annotated edition passed thru a new edition, likewise in Schaffhausen, as Vol. V of the four volumes that already contained the $I 774$ and $I 777$ editions of the "Satires" without notes.

When Ebert's translation of the "Night Thoughts" and other works of Young was published in the "Sammlung von Religions- und Sittenschriften," in Speier (I780), the new editor omitted the "Satires," declaring satire and religion incompatible and including the "Resignation" instead. Another anonymous edition, published in Frankfort in 1782 , refuted this opinion, however, and included the "Satires," on the ground that satire is a splendid, iconoclastic aid in the beneficent work of religious teachings.

When Professor Eckert published his improvement on Ebert, Mannheim, I780, he, of course, included the "Satires," practically another reprint of Ebert's already popular translation, which by this time had passed thru five editions, the Frankfort edition of 1782 being the sixth. Eckert's edition appeared again in 1784 , and then ten years elapsed before another came out. Ebert's final edition (I 794), annotated and with the English original, is the last one of the eighteenth century, the reprint published in Leipzig in I8I I being the very final one to appear.

The years 1804 and 1805 brought selections of verses of the "Satires" by Hensler, in Halem's Irene and in the Neue Teutsche Merkur, the last and only attempt of the nineteenth century to translate Young's "Satires."

No imitation was called forth in Germany, even influence seems lacking, beyond reviews and notices in periodicals and works of criticism. Schmid's "Theorie der Poesie" (I767) mentions the "Satires" favorably, and the "Betrachtungen über die englischen Dichter" (I779) considers the work excellent; otherwise the notices are very meager and are confined to Ebert's translation. 
The one writer, Göckingk, who left behind the most tangible proof of influence, did so in a short parody on Young, entitled "Golddurst," a poem of some sixty verses directed against the mercenary tendencies and corruption of the Germans, ${ }^{1}$ the opening verses of which run as follows:-

"Die allgemeine Leidenschaft

Ist nicht Ruhm! In meinem Vaterlande

Zum mindsten nicht. Denn ach! der Deutsche rafft

Nach Golde nur. Was kümmert ihn die Schande?

Was thut der Deutsche nicht für Gold! -

Ein schöner Ruhm! Ein Sprichwort edler Zonen!

Wie? bauet er, dem Britten gleich, sein Feld?

Und nährt er schon zu viele Millionen?”

\section{The Tragedies}

“Busiris, King of Egypt," “The Revenge," “The BROTHERS"

An anonymous prose translation of all three tragedies was published in 1756 and reprinted in 1767 , - the only editions including all three. The Beyträge zur neuesten Geschichte der Litteratur ( 1759 ) reviews these translations and praises Young's portrayal of natural characters, as follows: "His characters live and are the types that the stage needs, if the spectator is to be moved." Even the points in which the characters are overdrawn the reviewer excuses as exigencies of the stage. $\mathrm{He}$ commends the English license, but still is of the opinion that a little more moderation and closer observance of the Unities would make their plays still greater. Schmid's "Theorie der Poesie" (1768) reviews these translations, in the reprint of I 767 , as a "most miserable" rendition. The Bibliothek der schönen Wissenschaften is of the opinion that Young's tragedies read well, but are not successful on the stage.

$$
\text { (a) "Busiris" ( } 17 \mathrm{I} 9 \text { ) }
$$

The second translation of "Busiris" appeared, likewise anonymously, in Basel, in $175^{8}$, and was unfavorably reviewed by

\footnotetext{
${ }^{1} \mathrm{Cf}$. the $18 \mathrm{r} 7$ edition of his works.
} 
the Bibliothek der schönen Wissenschaften. Gottsched mentions only this one of the three tragedies in his "Handlexicon" of I760. "Busiris" was also done into prose by Eckert, in Vol. V of his I 784 edition of Young's works, - the best of the three translations that appeared in Germany. The Neue Bibliothek der schönen Wissenschaften ( 1767 ) says that the play has many good passages, which are, however, mingled with so much bombast and mediocrity, that one can not but wonder how a genius that attains such heights can fall so low.

\section{(b) "The Brothers" (I726) ${ }^{1}$}

The same year ( $\left.175^{6}\right)$ that produced the above-discussed, anonymous translation of Young's three tragedies also brought a second rendition of "The Brothers," anonymous and in prose. In $1764, \mathrm{~J}$. H. Schlegel, in Kopenhagen, translated the play, a good reproduction in blank verse, with a historical sketch appended, showing how closely Young followed his source in Roman history, Livy. The translation received very favorable criticism.

A third translation was published anonymously in Frankfort and Leipzig, in 1768 , very likely a reprint of the prose translation of 1756 and $1767 ;^{2}$ and a translation, bearing the title "Persius und Demetrius, oder die feindlichen Brüder," in monotonous Alexandrines, appeared the next year in Prague.

"The Brothers" was quite generally considered the weakest of Young's tragedies; the Neue Bibliothek der schönen Wissenschaften (I757) calls it a copy of a French play, ${ }^{3}$ and says the purpose was far better than the execution, Young having donated the proceeds to the poor. ${ }^{4}$ The Brittische Bibliothek, in

${ }^{1}$ Altho completed in 1726 , this tragedy was not made public until 1753 . Cf. W. Thomas: "Le poète Edward Young," pp. 184-185. It is discussed here before "The Revenge," however, because like "Busiris" it is less important.

${ }^{2}$ Cf. Bibliography, infra, i 768 .

3 As a matter of fact Young's tragedy, "The Brothers," is merely a plagiarized version of Corneille's "Persée et Démétrius."

4 Young had intended to donate the profits to the Society for the Propagation of the Gospel, and realizing only $£ 400$ on the play, he added $£ 600$ from his own purse. 
Leipzig, reviews, also in 1757 , "The Brothers" as acted in Drury Lane and points out the parallel in Corneille, but thinks that Young's treatment is superior to Corneille's, and that, altho inferior to "Busiris" and "The Revenge," its faults are due to the nation, not to Young. Schmid, on the contrary, in his "Anweisung der vornehmsten Bücher" (I78I) pronounces "The Brothers" Young's best tragedy; but he was very probably influenced by the superiority of Schlegel's translation.

\section{(c) "The Revenge" (I72I)}

This, the most successful of the three tragedies, was the one most translated and reviewed, the one most favorably received in Germany, and the only one that exerted any influence. The similarity to Shakspere's "Othello" was recognized at once by all, several critics even calling it "an improved Othello" $;$ but most of them judged it correctly as an imitation.

The Neue Bibliothek der schönen Wissenschaften, in 1767 , says the plot is borrowed from "Othello," the character of Zanga from Mrs. Behn's "Abdelazer," and gives a detailed comparison of "The Revenge" with "Othello." Schmid, in his "Theorie der Poesie" ( 1768 ), as well as in his "Anweisung der vornehmsten Bücher" ( 1781 ), calls Young's play an imitation of Shakspere.

The most important review of "The Revenge" was written by Gerstenberg in his Briefe über Merkwürdigkeiten der Litteratur (I 766). . In this article Gerstenberg considers "The Revenge" not so much a copy of "Othello" as "the converting of an irregular drama into a tragedy." The original he considers superior to the imitation, but, he says, considering merely violent emotions and tragical purpose, the palm goes to the imitator. ${ }^{3}$ Young, Gerstenberg continues, viewed the nature of jealousy from the side that was to wrest a shudder, horror, and sympathy from the heart. Shakspere endeavored to develop the finest (1760).

${ }^{1}$ Cf. Brittische Bibliothek (1757); Bibliothek der schönen Wissenschaften

${ }^{2}$ Cf. reprint in "Deutsche Litteraturdenkmale des 18 . und I9. Jahrhunderts." Vol. XXIX, pp. II4-125. $\quad{ }^{3}$ Cf. also, supra, pp. 23-24, 96-97. 
shades of jealousy and to reveal its most secret machinations. Young portrayed passions, Shakspere the sentiment of passions. In this tragedy Young's ignorance of man is revealed most clearly; the characters are drawn according to French patterns. Zanga, with all his villainy, is still depicted as a man of sublime philosophy like all of Young's heroes. Iago is a rascal who makes no pretensions to greatness of soul. In the portrayal of jealousy Young has successfully followed Shakspere, Gerstenberg admits, and he thinks that the struggle in Alonzo of love and hatred is depicted in such vivid colors that both the reader and spectator must burst into streams of tears.

And later, in the "Dritte Sammlung," discussing Shakspere, Gerstenberg says, "Young is magnificent and sublime; but his masterpiece will nevertheless always be the one tragedy that he created after Shakspere's great model." 1

Having, like the other two tragedies, been translated into prose by an unknown translator in 1756 , and reprinted in 1767 , "The Revenge" also appeared in the second anonymous translation of 1758 , with "Busiris," in Basel. "Die Deutsche Schaubühne" ( $176 \mathrm{I}$ ), of Vienna, contains Huber's translation, entitled "Zanga, oder die Rache." This is a stage version translated freely, in which the tragedy is remodelled to suit the taste of the translator, as is indicated in his words, "a new tragedy in prose, taken from the English of Young." In Act V, Leonore dies on the stage and is not led out by Isabella, and the greatest heightening of effect is produced by the change which makes Zanga stab himself with the dagger that he tears out of Alonzo's breast.

Schmid's "Theater der Britten" reprinted one of the earlier anonymous prose translations, for which the Almanach der deutschen Musen of Leipzig ( $177 \mathrm{I}$ ) censured him, on the ground that such miserable translations should not be continued. Eckert's translation, "Die Rache," appeared in 1784 , and, as in the case of "Busiris," is the best German version of Young's "Revenge."

The final translation is by Blümner (I794), likewise in prose. In the preface, the translator calls this the "work of a genius," and expresses his opinion that it ought to find a warm reception in Germany, considering the prevailing dearth of good plays.

\footnotetext{
${ }^{1}$ Cf. "Litteraturdenkmale," l.c. p. 277.
} 
Blümner considers "Othello" superior as a natural character. In "The Revenge" he sees the hand of the artist; it is more brilliant, tho Shakspere's play is more true to life; and yet, the critic goes on to say, the admirable manner in which Zanga leads his victim on, the excellent struggle between Alonzo's love and his desire for revenge, the denouement and final catastrophe, all show the thinking poet and raise him above the rank of a mere imitator. This version combined Acts III and IV, since they really form one element in the plot. At the end of Act $\mathrm{I}$, the parting of Leonore and Alonzo in sorrow and uncertainty was changed into a happy declaration of love, and at the end of the play, altho Zanga is led off, as in Young, the final speech of Alvarez is omitted.

"Busiris" and "The Brothers" did not possess the qualities to make them good stage plays, and were too weak to inspire imitation. "The Revenge," however, as the stage versions of Huber and Blümner would indicate, was better adapted to the stage; it was read more and was taken as model for the two tragedies, "Der Freygeist" and "Brutus," of the youthful dramatist

JoAchim Wilhelm von BraWe (1738-1758)

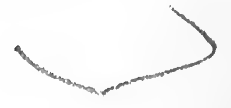

The similarity of the "Freygeist," written in $175^{6-1} 757$ and printed in 1758 , to Young's "Revenge" attracted attention at once, and Ramler dwells upon it in the introduction to the first edition, claiming that this similarity is no blemish on the honor of the young dramatist. Lessing's "Miss Sara Sampson" was also a model, but that does not concern us here.

The main points of similarity between the "Freygeist" and "The Revenge" are as follows:" As Alonzo is led by Zanga to believe his wife untrue and to have his friend Carlos murdered as the paramour who has claimed her affections, and finally to kill himself; so Cleredon of the "Freygeist" is induced by his rival Henly to believe his former sweetheart unfaithful, and to kill his best friend in a duel, after which he slays his false

1 These facts on Brawe are all taken from the excellent monograph, "Joachim Wilhelm Brawe. Der Schüler Lessings." August Sauer. Strassburg, 1878 . Cf. pp. $42-45,70-73$. 
friend Henly and himself. The same means are employed, lies and forged letters; and after the accomplishment of his purpose, Henly like Zanga confesses his plans of revenge in triumph, and gloats over his victim. The opening scenes of both dramas are similar: the plan of revenge is developed similarly, it is to be the life's work of both villains; simple murder will not suffice, their victims must be tormented and painfully racked. Life has no more worth for the villains after their deed has been done. The whole tone is that of Young's "Revenge"; in both tragedies the gloomy cloud of revenge hovers over the victims ready to burst at any moment.

Brawe's second tragedy, "Brutus," completed in $\mathrm{r} 75^{8}$, shortly before his death, but not published until ten years later, also shows very plainly influence of "The Revenge," perhaps not in so many details, but much more in the main traits. In both there is the element of patriotism, and national hatred is allied with family hatred. As Alonzo had killed in battle Zanga's father, a Mohammedan prince, and had made captive and slave the son who as heathen hated the Spaniard; so in "Brutus," Publius, as Samnite, is the deadly enemy of the Romans. Brutus has killed Publius's father and brothers in battle. Publius, like Zanga, seeks to avenge the protracted servitude of his race on the man whom he hates personally. He feels the spirits of his fallen countrymen calling for vengeance; he invokes them for aid, and, after the success of his deed, he calls upon them to rejoice with him. And as Zanga gloats over his crushed victim, Publius is too overcome with joy at the sight of the annihilated Brutus to desire anything more as satisfaction.

Thus Young's "Revenge" came into Germany at the time when Lessing's "Miss Sara Sampson," having been inspired by Lillo's "George Barnwell," had taught the Germans, as Lillo had shown the English, that the bourgeoisie also furnished suitable material for serious tragedy. "The Revenge" worked hand in hand with this movement, and thus became one of the prototypes of the new drama in Germany, built upon the pathos of the life of the middle classes. ${ }^{1}$

1 The name of the Moor, Zanga, in Grillparzer's "Der Traum, ein Leben," was most likely taken from Young's character; but there is no influence. Both 


\section{The Minor Works included in Ebert's Translation of $\mathrm{r} 754-\mathrm{r} 756$}

These works, which remained practically without influence upon German literature, have nevertheless left behind proof of the fact that they were read, and that they aroused at least a passing interest among the German reading public.

Ebert, having completed his labors on the "Night Thoughts," in $175^{1-175^{2}}$, for the first edition, turned his attention to Young's less important prose and verse, which can be most easily followed in the various editions of this translation of $1754-1756$. These works are: "A Poem on the Last Day" (I7I3), "The Force of Religion or Vanquished Love" (I7I4), "A Paraphrase on Part of the Book of Job" (I7I9) - the translation of which appeared in 1754 ; "A Vindication of Providence: or, a True Estimate of Human Life" ( 1728 ) - which was translated in 1755; "Two Epistles to Mr. Pope concerning the Authors of the Age" (I 730), "The Centaur not Fabulous: in Five Letters to a Friend, on the Life in Vogue" (1755) - which appeared in translation in 1756 .

These works were all included in Part II of the new collection by Ebert, entitled: "Einige Werke von Dr. Eduard Young" (1767, 1777, 1799); in the Speier edition, "Sammlung von Religions- und Sittenschriften," Vols. II-III, I780; in the reprint in Frankfort (1805); and in Eckert's edition of Young's works, Vols. III-IV, Mannheim, I780-1784, virtually another edition of Ebert's translation. These editions are all in prose, German text only, without notes, and passed without reviews or notices in contemporary literature.

\section{(a) "A Poem on the Last Day" (I7r3)}

Steele's Guardian brought the first verses of the "Last Day" into Germany, so unostentatiously, however, that their presence

villains are enslaved captives, but Young's Moor leads his victim on in order to avenge his wrongs, whereas Grillparzer's Zanga simply desires to gratify his longing for a martial career. 
was hardly detected. That periodical of $\mathrm{I} 7 \mathrm{I} 3 \mathrm{contains} 26$ verses of this poem shortly to appear, and so, when Louise Gottsched published her translation as Der Aufseher, Leipzig, I 745, she incidentally became the first German translator of verses of the "Last Day."

In 1757 , three years after Ebert's translation, a hexameter translation was published in Basel, in "Vier auserlesene Meisterstücke so vieler englischen Dichter," etc., which was reviewed in the Litteraturbriefe by Lessing. The translation purporting to be Elizabeth Rowe's "Auserlesene Poesien aus den meisten und besten Englischen Dichtern," Zürich, I76r, contains eleven selections from the "Last Day" in rimed trochaic octameters, unfavorably reviewed in the Leipziger Zeitungen, and in $\mathrm{I} 760$, Gottsched's "Handlexicon" contains a citation from the poem; while a notice, in 1804, of Dmochowski's Polish translation appeared in the Göttingische Anzeigen.

Lessing, in his "Hamburgische Dramaturgie" ( $\mathrm{I}_{7} 67$ ), cites verse 60 of Book I: "Young sagt von der Sonne, es wäre Sünde in den Heiden gewesen, sie nicht anzubeten." 1 J. A. Schlegel, in his poem "Von der Hölle," draws a picture of the Judgment Day in language that resembles Young's "Last Day," ${ }^{2}$ but which may also owe its origin to "Night Thoughts," IX. Influence of the "Last Day" is very uncertain and difficult to determine, since most of the remarkable passages have parallels in the "Night Thoughts," which were, of course, better and more widely known.

Gottsched's "Handlexicon" ( 1760$)$, Schmid's "Anweisung der vornehmsten Bücher" ( $178 \mathrm{I}$ ), and Blankenburg's "Litterarische Aufsätze" (I796) contain notices of the "Last Day," the "Force of Religion," and the "Paraphrase on Part of the

1 R. Boxberger ("Lessings Werke," Kürschner's "D. N.L.," Vol. X, p. I69), in his note to this passage, cites "Night Thoughts," IX, verses 799-807 of Kayser's hexameter translation of I $_{76}$ I (falsely given as $\mathrm{I} 760$ ), Vol. II, p. 355 . Dr. Cosack, in his "Materialien zur Hamburgischen Dramaturgie," p. $22 \mathrm{I}$, having pointed out that the passage cited by Lessing is found verbatim in the "Last Day," Book I, verse 60, Boxberger, in the Archiv für Litteraturgeschichte, Vol. VIII, pp. $437-438,1879$, acknowledged the correction and incorporated it in his note.

${ }^{2}$ Cf. Barnstorff, l.c. p. 26. 
Book of Job," but with the exception of these notices these works have left behind no trace in Germany. The notices in the Leipziger Zeitungen of $\mathrm{I} 728$ and $\mathrm{r} 73 \mathrm{I}$, of the "Vindication of Providence" are the first mentions of Young or his works in Germany, and the last of this particular sermon. The "Epistles to Mr. Pope" also received the first and last notice in that Leipzig periodical, in 1737 .

\section{(b) "The Centaur not Fabulous" (I755)}

The "Satires" had to wait twenty years for an introduction into Germany (I745), but the "Centaur," appearing at the time when interest in Young was intense, naturally received immediate attention, so that the same year (I755) that produced the first translation of the "Satires," thirty years after they were written, also saw the first translation of the "Centaur," which Young had published in London only that very year.

As early as May, I755, the Leipziger Zeitungen had reviewed the first English edition, and by October that periodical was able to publish a review of the first German translation. This is a better piece of work than the translation of the "Satires," and received many very favorable reviews. Ebert's translation appeared the next year, and passed thru seven editions, as shown above; but the anonymous translation of 1755 was the only one to receive special notice.

Like the "Satires," the "Centaur" exerted little tangible influence upon German writers. There are scattered indications that the work was read, none that it was followed or imitated. The reason is probably to be found in the fact that in it Young is the moral preacher, who had said all he had to say about the world and man in a far better manner in his "Night Thoughts." Herder said (I80I) Young's "Night Thoughts" and "Centaur" were probably read less, because the people saw their own images in Lorenzo and the Centaur." The "Night Thoughts" were read zealously, however, and whether Herder judged correctly the failure of the public to read the "Centaur" is not attested by literary documents. The real reason is very

${ }^{1}$ Cf. "Werke." Suphan edition. Vol. XXIV, p. 106. 
likely that already given above, the fact that the "Night Thoughts" overshadowed this work, which after all offered very little that was new.

\section{(4) "Resignation" AND Other Minor Works}

\section{(a) "Resignation"}

The "Resignation" ( 1762 ), Young's last work, was first translated, in $I 763$, by Dusch in Altona, under the title "Die Verläugnung," and a little later the same year, by Ebert in Braunschweig, under the title "Die Gelassenheit im Leiden," both in prose. Ebert's translation has the German text only, whereas Dusch printed the original on the pages opposite. Both were reviewed immediately after their appearance, Ebert's favorably, Dusch's with both ardent praise and severe criticism. Dusch's translation appeared in only this one edition, whereas Ebert's was published in two others ( $1766, I_{776}$ ), the second passing without notice, the third being favorably reviewed.

Ebert's edition was further reprinted in the I 782 , Frankfort, supplementary volume to the Speier edition of Ebert's translations, but was not included in Eckert's copy of Ebert (I784).

The "Handbuch der Englischen Sprache" (I793) contains verses $I-I 2$ of the poem in the original, and the story of the "Resignation" in German literature is told. Being a weak repetition of many of the maxims of the "Night Thoughts," it is quite natural that no influence should have been exerted by the poem.

\section{(b) Odes and Lyrics}

I. "Ode to the King." II. "A Discourse on Lyric Poetry." III. "Ocean: An Ode" (I728). "Imperium Pelagi: A Naval Lyric. Preface. The Merchant" (I730). IV. "SeaPiece: Containing I.-The British Sailor's Exultation. II.His Prayer before Engagement" (I 733).

Young's treatise on lyric poetry was translated in "Sammlung vermischter Schriften" (I 759), and the fifth volume of Eckert's translation ( $\mathrm{I} 784$ ) contains a German version of the "Sea- 
Piece." These are the only ones of the above-named short works of Young that were translated into German.

An edition of the English original of the "Sea-Piece" was published in Vienna, in 1783 , however, and the Unterhaltungen of Hamburg, in 1770 , announced the publication posthumously of "The Merchant." The reviewer says that this mediocre poem, if it is really one of Young's, should never have been published, since Young had not talent for the lyric. This is the attitude of all the critics who mention Young's odes and lyrics. Schmid's "Theorie der Poesie" ( 1767 ) calls lyric poetry Young's weakest side; his "Anweisung der vornehmsten Bücher" (I78I) reviews the four odes as the least important productions of Young's pen, and sees in the fact that "The Merchant" was not published by Young himself, the poet's own hatred for the work." Blankenburg's "Zusätze" (I 796) brings a notice of the I759 translation of the "Discourse on Lyric Poetry," and speaks of Young's four "cold odes."

(c) Gottsched, who, in his sketch of Young in the "Handlexicon" of 1760 , forgot to mention the "Night Thoughts," "Satires," and "Conjectures," the "Centaur," "Revenge," and "Brothers," includes seven of the least important writings of Young, of which three received no other mention elsewhere in Germany. These are: "On Michael Angelo's Famous Piece of the Crucifixion" (I7 18), "On the Late Queen's Death" (I7I4), "A letter to Mr. Tickell, occasioned by the Death of the Right Hon. Joseph Addison, Esq." (I 7 I9).

Of the "Epistle to the Right Honourable George Lord Lansdowne" (I7I2), which Gottsched also includes, about fifty verses were published in English, in the Brittische Bibliothek of 1778 , and Ebert discusses this "Epistle" in the Deutsches Museum ( 1780 ), in a letter to Eschenburg.

One could hardly expect such ephemeral local writings to influence German readers, but the mere fact that they were mentioned in Germany, and that some were translated, furnishes a very strong proof of the intensity of the interest taken at that time in Young on the other side of the Channel.

1 Young had, as a matter of fact, published this poem in I730, but he later rejected it when he published collected editions of his works. 


\section{CHAPTER V}

\section{BIBLIOGRAPHY OF GERMAN TRANSLATIONS, EDITIONS, REVIEWS, AND NOTICES}

\section{INTRODUCTION}

THE following bibliography contains the results of research in all the leading German libraries and bookshops, but does not claim absolute completeness. The material given is, with very few exceptions, based upon personal investigation. In a few cases, however, it was impossible to find the works cited or to obtain them for personal perusal; but, being mostly of minor importance, sufficient data could be gathered from reviews in most cases. Such examples are always noted.

It is the purpose of this bibliography to furnish as complete a list as possible of the German translations and editions of Young's works with the pertinent notices and reviews in chronological order, so as to reflect in contemporary literature a picture of the reception that was accorded to Young in Germany. The reviews are not arranged chronologically, but are, wherever possible, appended to the works they review. Some of the most important articles, especially those that do not hinge directly upon some definite edition or translation, are given independent notice. Titles are as a rule given as found, retaining, as far as feasible, antiquated spelling, punctuation, etc. In the case of periodicals and works of minor importance, abbreviations are used, but the titles of translations are in most cases a reproduction of the original title-page, even including the house of publication, later editions being abbreviated and referring back to the first notice for fuller data.

Special completeness was aimed at for the decades $175^{\circ}-1780$, in which Young exerted the greatest influence, but even here the bibliography does not claim absolute completeness. There may 
be other reprints of Ebert's translations, for instance, that it was impossible to locate; besides, dates in catalogs are often wrongly printed. After 1800 only the translations and most important notices are included. No attempt was made, for example, to include the hundreds of text-books, anthologies, and works on literary criticism and history, in which Young's works are treated without special bearing.

\section{BIBLIOGRAPHY}

1728. Neuer ${ }^{1}$ Zeitungen von Gelehrten Sachen des Jahres MDCCXXVIII. Anderer Theil. Leipzig. (Vol. XIV.)

Notice, p. 607, dated Leipzig, Aug. 5, of the publication, in "Londen," of A Vindication of Providence, a sermon by "Herr Young."

I731. Neuer Zeitungen von Gelehrten Sachen des Jahres MDCCXXXI. Anderer Theil. Leipzig. (Vol. XVII.)

Notice, p. 482, dated Leipzig, July 9, of the appearance, in "Londen," of the third edition of the above-mentioned sermon by " $D$. Young," under the title, A True Estimate of Human Life.

I737. Nöthiger Beytrag zu den Neuen Zeitungen von Gelehrten Sachen, oder Umständliche Auszüge aus denen Gelehrten Monatsschriften, welche in den Neuen Zeitungen von Gelehrten Sachen nicht Platz hatten. Anderer Theil. Leipzig. II. Band, r8. Stück, pp. 286-287: 2) Two Epistles to Mr. Pope concerning the Authors of the Age. 1730 .

A very favorable review of the purpose and merit of these epistles.

I 745. Neuer Büchersaal der schönen Wissenschaften und freyen Künste. Des I. Bandes, I. Stück. Leipzig, im Monat Julii. (Gottsched.) Pp. 52-73: Review of the Love of Fame, the universal Passion, in seven characteristical Satires. The fourth edition. London, 174I. D. i. Die Liebe zum Ruhme, als die

${ }^{1}$ This title is given as found upon the title-page. 
allgemeine Leidenschaft, in sieben Satiren vorgestellt. Vierte Auflage.

A very favorable review in which Gottsched attributes the Satires to Glover. The first four Satires are very carefully analyzed, and $\mathrm{x} 3^{\circ}$ verses are quoted from the original and translated into German prose; then follows a general statement of the nature of Satires V-VII.

Der Aufseher, oder Vormund. Aus dem Engländischen ins Deutsche übersetzt von L. A. V. G(ottschedin). Leipzig, I 745 .

This is the first German translation of the Guardian and contains I6 verses of the manuscript of the Last Day, before its publication, p. 262; ro verses, p. 264. The latter selection is Book I, verses $13-22$, whereas only 8 verses of the first selection, the original opening of Book II, were retained by Young in the poem when published, slightly altered, as verses $5^{-12}$ of Book II.

I746. Göttingische Zeitungen von Gelehrten Sachen auf das Jahr MDCCXLVI. Göttingen, 22. Stück. Den I7. Martius.

Under London, P. I73, there is a notice of the completion of the excellent didactic poem "desz D. Younge the nightothougths." 1

Neuer Zeitungen von Gelehrten Sachen auf das Jahr MDCCXLVI. Erster Theil. Leipzig, den r6. Jun.

Notice of the completion of the Night Thoughts, pp. 457-458, among the new announcements from London. Contains a very favorable review.

1749. Neue Critische Briefe über gantz verschiedene Sachen von verschiedenen Verfassern. Zürich, I749.

The 35th "Brief," pp. 287-289, contains a poem entitled An Sipha, dealing with the theme of friendship, and is a free translation and adaptation of Night II, verses 46I-537. The 56th "Brief," pp. 39I399, contains a very favorable review of the Satires and their purpose, as outlined by Young in his preface. Satire II, ${ }^{2}$ verses $2 \mathrm{I}-44$, are translated into blank verse. The 57th "Brief," pp. 399-40r, contains numerous selections of the Satires in prose translation. The 64th "Brief," pp. 448-45I, has a glowing tribute to the Night Thoughts, and a translation of verses $627-648,677-689$ of the sixth Night. These translations are probably by Bodmer himself. ${ }^{3}$

${ }^{1}$ Corrected in a note on p. 188 , to "nightthougths."

${ }^{2}$ Incorrectly cited as Satire I. ${ }^{3}$ Cf. supra, p. I21. 
1750. Göttingische Zeitungen von Gelehrten Sachen auf das Jahr MDCCL. Göttingen, ro3. Stück. Den I2. October.

Under London, pp. 819-820, notice is given of a new and better edition of the "nigth thougths," followed by a review that characterizes Nights V-IX.

I75I. Uebersetzungen einiger Poetischen und Prosaischen Werke der besten Englischen Schriftsteller. Erster Band. Worinn folgende drey Gedichte von D. Eduard Young enthalten sind: Klagen, oder Nachtgedanken über Leben, Tod, und Unsterblichkeit: Der Jüngste Tag: Und eine Paraphrase über einen Theil des Buchs Hiob. Erstes Stück. Braunschweig und Hildesheim, verlegts seel. Ludolph Schröders Erben, I $75 \mathrm{I}$.

This translation, the preface of which bears the date of April Io, I75 I, is the first by Prof. Johann Arnold Ebert. ${ }^{1}$ Vol. I, Parts I and II, contains the first seven Nights translated into prose, $3^{16} \mathrm{pp}$. The last two Nights did not appear until I 752, q.v. The second edition appeared in 1753 , the third in 1756 , and the fourth in 1763 , q.v.

Reviews: Critische Nachrichten aus dem Reiche der Gelehrsamkeit. Auf das Jahr I751. Berlin, I752. 26. Stück, pp. 206-207. A very favorable review, which betrays the fact that the writer was not acquainted with the original, in the statement that the Night Thoughts consist of four Nights, and in the mention of rime.

Crito. Eine Monatsschrift. Zürich, 175I. This review is reviewed in turn by the Westphälische Bemühungen zur Aufnahme des Geschmacks und der Sitten. Lemgo, I753. Erster Theil. Zweites Stück, pp. I 16-122.

1752. Uebersetzungen einiger Poetischen und Prosaischen Werke der besten Englischen Schriftsteller. Erster Band. Drittes Stück. Braunschweig und Hildesheim, verlegts seel. Ludolph Schröders Erben, I752.

This volume contains Nights VIII-IX, pp. $3^{19-507}$, and is a continuation of Ebert's translation of $\mathrm{I} 75 \mathrm{I}$, q.v. The second edition appeared in 1753 , the third in 1756 , and the fourth in $1763, q . v$.

Der Christen-Sieg als das einzige Mittel wider die Furcht des Todes aus denen Nachtgedanken des Herrn Young

1 Ebert was not appointed Professor until I753, to be sure. 
ins Teutsche übersetzet von Hartmann von Geusau. Jena, bey Christian Heinrich Cuno, I752.

This is a translation of Night IV, into Alexandrines. It is an adaptation rather than translation of Young, done into very miserable, monotonous verses. vi $+88 \mathrm{pp}$. The preface bears the date of Feb. 20, I752.

Reviews: Neuer Zeitungen von Gelehrten Sachen. Leipzig, I 752, p. $54^{2}$.

Göttingische Zeitungen von Gelehrten Sachen. Göttingen, I752, p. 372 .

Klagen, oder Nachtgedanken über Leben, Tod, und Unsterblichkeit. Englisch und Deutsch. Die vier ersten Nächte. Göttingen, bey Johann Wilhelm Schmidt, Univ. Buchhändler, I $75^{2}$.

This translation, which appeared anonymously, is the work of Ch. B. Kayser. It contains, as preface, selections from Tscharner's letter to Haller on the circumstances that gave rise to the Night Thoughts. It is in hexameters, and prints the English original on the pages opposite. $225 \mathrm{pp}$. For the enlarged and revised edition, cf. infra, I760, I 76 r.

REVIEwS: Göttingische Zeitungen von Gelehrten Sachen. Göttingen, $175^{2}$, pp. 589-390. Favorable. This is by Haller.

Berlinische Privilegirte Staats- und gelehrte Zeitung, 1753, pp. 152-153. This review is by Lessing, who hopes the translation will be continued. Cf. the Lachmann-Muncker edition of Lessing's Works, Vol. V, pp. I52-153.

Gelehrte Nachrichten. Rostock und Wissmar, I753, pp. 452-453.

An Young.

An ode by Klopstock, "Stirb, prophetischer Greis, stirb!" etc., written in $\mathrm{I}^{752}$, while learning English from the Night Thoughts. I6 verses. To be found in all the editions of Klopstock's works. Used as frontispiece in Sternau's translation; cf. I825, I827.

I753. Uebersetzungen einiger Poetischen und Prosaischen Werke der besten Englischen Schriftsteller. Erster Band. Worinn D. Eduard Youngs Klagen, oder, Nachtgedanken über Leben, Tod, und Unsterblichkeit, enthalten sind. Zweyte und verbesserte Auflage. Braunschweig und Hildesheim, I753.

This is the second edition of the translation by Ebert, which appeared in $175^{1-1752 . ~ T h e ~ t h i r d ~ e d i t i o n ~ a p p e a r e d ~ i n ~} 1756$, and the 
fourth in $176_{3}, q . v$. The revision in these editions consists in very minor changes in phraseology.

Hamburgische Beyträge zu den Werken des Witzes und der Sittenlehre. Hamburg, I753. Drittes Stück.

This contains the following selections from the Satires, mostly translations. Some are adaptations rather than close translations.

Der Patriot. Nach dem Young, p. 737. 20 verses. Satire IV, verses $15-36$.

Der Witz vieler Schönen. Nach Ýoung, p. 739. 12 verses. Satire V, verses I3-I44.

Julchen. Nach Young, p. 742. I8 verses. Satire V, verses 297-308.

Der Hunger und die Liebe. Nach Young, p. 743. Io verses. Satire V, verses 309-318.

Die Ewige Liebe. Nach Young, p. 744. Io verses. Satire V, verses $322-328$.

En einen Liebhaber schöner Bände. Nach dem Young, p. 748. 8 verses. Satire II, verses $57^{-62}, 96-97$.

1754. Hamburgische Beyträge zu den Werken des Witzes und der Sittenlehre. Zweyter Band, erstes Stück. Hamburg, I754: Der Rückfall. Von Dr. Eduard Young, pp. $33-78$.

This is a translation of Night V, I068 verses, in the original blank verse. The introduction says that it is the work of the late Herr Oeder of Thron, who found special consolation in this Night, after the death of his son. Herder published the first 66 verses of this translation in his Adrastea, Part V, pp. 293-295, in 1803, q.v. infra.

Uebersetzungen einiger Poetischen und Prosaischen Werke der besten Englischen Schriftsteller. Zweyter Band. Erstes Stück. Braunschweig und Hildesheim, I754.

This contains Ebert's first translation of: Der Jüngste Tag; Die Macht der Religion; Paraphrase über einen Theil des Buches Hiob, I44 pp. Some editions bear the date 1762 , which is, however, only a new title-page for this first and only edition. This is the first part of the second volume of Ebert's translation, the first volume of which includes the Night Thoughts. Cf. I75I-I 752 .

I755. Klagen, oder Nachtgedanken, von Leben, Tod und Unsterblichkeit. Eine freye poetische Uebersetzung aus dem Englischen des Herrn Young. Frankfurt am Mayn, bey Johann Friedrich Fleischer, 1755. 
An anonymous, trochaic octameter translation of Night I, with fixed cæsura and rime in couplets. 29 pp., quarto, without pagination. Reprinted as No. I, in Drey Auserlesene Gedichte, I759, I762, q.v.

Die Ruhmbegierde, die Hauptleidenschaft der Menschen. In Sieben Satiren. Von Dr. Edward Young. Aus der fünften englischen Auflage übersetzt. Frankfurt und Leipzig, in der Knoch- und Esslingerischen Buchhandlung, I755.

An anonymous translation into prose of the Satires. r60 pp. Rather poor. For the second, revised edition, cf. infra, 1756.

Der nicht fabelhafte Centaur in sechs Briefen an einen Freund über das im Schwange gehende Leben. Aus dem Englischen Herrn D. Eduard Youngs. Leipzig, verlegts Johann Gottfried Dyck, I755.

An anonymous translation, the first of the Centaur to appear. $222 \mathrm{pp}$.

ReVIews: Neuer Zeitungen von Gelehrten Sachen. Leipzig, r 755, p. 773, under the date of Oct. 30. The same volume, p. 36r, May 22, had reviewed the first English edition. Both reviews are very favorable.

Gelehrte Nachrichten. Rostock und Wissmar, I756, pp. 7-8, 15-16. Praise for both the original and the translation.

Freye Urtheile und Nachrichten zum Aufnehmen der Wissenschaften und Historie überhaupt. ' Hamburg, I756, p. 200. Favorable.

Bibliothek der schönen Wissenschaften und der freyen Künste, Vol. III, i, p. 200, 1758 .

Uebersetzungen einiger Poetischen und Prosaischen Werke der besten Englischen Schriftsteller. Zweyter Band. Zweytes Stück. Braunschweig und Hildesheim, I755.

Ebert's first edition of: Der wahre Wehrt ${ }^{1}$ des menschlichen Lebens. I24 Pp.

Neue Erweiterungen der Erkenntnis und des Vergnügens. Frankfurt und Leipzig, I755. VIII. Des Herrn von Bar Selbtsgespräch bey dem frühzeitigen Tode des Herrn von Hagedorns, etc.; ins Deutsche übersetzt, pp. 8I-86. IX. Sinngedicht auf des Herrn von Bar Selbstgespräch bey des Herm von Hagedorns Tode, p. 86.

1 Ebert's spelling. 
Verses 9-I2, p. 8r, show that the inspiration came from the Night Thoughts. There is also a long footnote on the Night Thoughts and their cause. The poem, on p. 86, proclaims Bar the Young of Germany's fame, and is by the translator of the above-cited verses.

These poems are reprinted in: Auszug merkwürdiger Sachen aus den Neuesten Monatsschriften der Gelehrsamkeit. Merseburg, 1755. (The title-page bears the date I754.) Vol. I, pp. I6I-I66.

I756. Uebersetzungen einiger Poetischen und Prosaischen Werke der besten Englischen Schriftsteller. Erster Band. Worinn D. Eduard Youngs Klagen, oder Nachtgedanken über Leben, Tod, und Unsterblichkeit, enthalten sind. Dritte und verbesserte Auflage. Braunschweig und Hildesheim, 1756 .

Contains the nine Nights, 507 pp., the third edition of Ebert's prose translation of $1751-175^{2}$. The second edition appeared in 1753 , the fourth in $1763, q . v$. There is a reprint of Part II, Nights V-VII, bearing the date 1762 .

Der Triumph der Christen über die Furcht des Todes. Eine freye poetische Uebersetzung aus dem Englischen des Herrn Young. Frankfurt am Mayn, I756.

An anonymous translation of Night IV. into trochaic octameters, with rime in couplets, evidently by the translator of Night I, I 755, q.v. 50 pp., quarto, without pagination. Reprinted as No. 3, in Drey Auserlesene Gedichte, I 759, I762, q.v.

Ruhmbegierde, die allgemeine Leidenschaft der Menschen. In Sieben Satiren. Von Dr. Edward Young. Aus der fünften Englischen Auflage übersetzt und in diesem zweyten Druck verbessert. Frankfurt und Leipzig, in der Knoch- und Esslingerischen Buchhandlung, I756.

The first edition appeared in $\mathrm{I} 755$, q.v. $\mathrm{I} 73 \mathrm{pp}$.

Uebersetzungen einiger Poetischen und Prosaischen Werke der besten Englischen Schriftsteller. Zweyter Band. Drittes Stück. Braunschweig und Hildesheim, verlegts seel. Ludolph Schröders Erben, I756.

This volume contains: Der nicht fabelhafte Centaur; Zwey Poetische Sendschreiben an Herrn Pope, translated by Ebert. $33^{6} \mathrm{pp}$. For the other volumes of this translation, cf. under I751, I752, 1753, I $754, \mathrm{I} 755, \mathrm{I}_{76}$. 
D. Eduard Youngs Trauerspiele, nebst der Boadicea, einem Trauerspiele des Herrn R. Glovers. Aus dem Englischen übersetzt. Hamburg und Leipzig, bey Georg Christian Grund und Adam Heinrich Holle, I 756 .

This anonymous translation contains: Busiris; Die Rache; Die Brüder. 322 pp. A reprint was published in Leipzig, 1767 , q.v.

Reviews: Gelehrte Nachrichten. Rostock und Wissmar, 1757, pp. $135^{-1} 36$.

Beyträge zur Neuesten Geschichte der Litteratur, besonders des ${ }^{1} 757^{\text {sten }}$ Jahrs. Altona, I759, pp. I49-15I. Praises natural portrayal of character, but desires closer observance of the Unities.

Die Brüder. Ein Trauerspiel, von Dr. Eduard Young. Aus dem Englischen übersetzt. Franckfurt und Leipzig. In der Knoch- und Esslingerischen Buchhandlung, $175^{6}$.

An anonymous prose translation, of $15^{8} \mathrm{pp}$.

I757. Brittische Bibliothek. Erster Band. Leipzig, I757.

Notice and review of the first edition, in London, of the Centaur not Fabulous ( 1755 ), in Zweytes Stück, pp. I67-175. A careful detailed review. The critic pronounces it too poetical for prose, too witty for such a serious subject, and yet, he thinks, this very wit is the charm of the book.

Notice and review of: The Brothers, a Tragedy. Acted at the Theatre Royal in Drury-Lane. London. Printed for R. Dodsley in Pall-Mall, r753. In Drittes Stück, pp. 256-293. This reviewer calls the Revenge "an improved Shakspere's Othello." The theme of the Brothers had already been used by Corneille, says the critic, but Young is superior to Corneille. Dodsley's Prologue is translated complete, pp. 258-259. Résumé of the entire play, scene for scene, with occasional quotations and criticisms, pp. 260-293. It is inferior to Busiris and the Revenge, but its bombast and other faults are the faults of the nation, not of Young, the reviewer concludes.

Bibliothek der schönen Wissenschaften und der freyen Künste. Leipzig, I757. Vol. I, i, IV : (A review of) Aufmunterungen in moralischen Gedichten von Joh. Lorenz Withof, etc. Dortmund, I755.

A short comparison of Pope and Young, pp. 87, 95. 
Bibliothek der schönen Wissenschaften und der freyen Künste. Leipzig, I757. Vol. I, ii, I: Betrachtungen über die Quellen und die Verbindungen der schönen Künste und Wissenschaften, pp. 23I-268.

A criticism of Young's tragedies, p. 260, says they read well, but they are not successful stage plays.

Vier Auserlesene Meisterstücke so vieler englischen Dichter, etc. Basel, I757.

This volume contains Young's Last Day in hexameter translation. It was not to be had.

REVIEW: Briefe, die neueste Litteratur betreffend. 39th "Brief," pp. $280 \mathrm{ff}$. This review is by Lessing. Cf. the Lachmann-Muncker edition of his works, Vol. VIII, pp. $79 \mathrm{ff}$.

1758. Der Nordische Aufseher, herausgegeben von Johann Andreas Cramer. Erster Band. Kopenhagen und Leipzig, $175^{8}$.

Dreyzehntes Stück, pp. 158-182. This is the review of the worth of the Night Thoughts that places Young next to David and the Prophets. An analysis of Night IV is given, pp. 164-18r, quoting about 225 verses in German prose translation.

REviEws: Briefe, die neueste Litteratur betreffend. Berlin, I759. The 48th "Brief" finds the above-mentioned praise exaggerated. This review is by Lessing. Cf. the Lachmann-Muncker edition of his works, Vol. VIII, pp. 125-126.

Bibliothek der schönen Wissenschaften und der freyen Künste. Leipzig, r759. Vol. V, ii, pp. 280, 281.

Neue Probestücke der Englischen Schaubühne, aus der Ursprache übersetzt von einem Liebhaber des guten Geschmacks. Basel, I758. I, I, Rache; 3, Busiris.

This translation was not to be had.

REviEw: Bibliothek der schönen Wissenschaften und der freyen Künste. Leipzig, I 760. Vol. VI, i, p. 73. Adverse criticism. This reviewer also calls the Revenge, Shakspere's Othello improved.

Gelehrte Nachrichten auf das Jahr I758. Rostock und Wissmar.

Under the date of April 30, p. 196, Young's appointment as Bishop of Bristol is announced. 
Bibliothek der schönen Wissenschaften und der freyen Künste. Leipzig, I $75^{8}$.

A review, Vol. III, ii, pp. 34I-36r, of Ramler's Einleitung in die schönen Wissenschaften, a translation of the French of Batteux, cites a passage of Ebert's translation of the Night Thoughts, to illustrate poetical forms in harmonious, exalted prose, p. 356 .

Zum Vergnügen. Hamburg und Leipzig, I758. Das Io. Stück, pp, 73-80: Vorurtheile der Freundschaft.

A long treatise on close and intimate friendship, resembling Young's thoughts on the subject in the second Night, verses 505-515, 465-479, of which are quoted in translation.

Herrn Abt Batteux ... Einschränkung der Schönen Künste . . . aus dem Französischen übersetzt . . von Johann Adolf Schlegeln. Leipzig, I758.

Vol. II, pp. $177^{-1} 78$, contains a favorable discussion of the Night Thoughts and of Ebert's translation. The second edition appeared in 1759 , the third in 1770 .

I759. Drey auserlesene Gedichte. Eine freye poetische Uebersetzung aus dem Englischen des Herrn Young. Frankfurt und Leipzig. In der Fleischerischen Buchhandlung, I759.

Contains: (I) Klagen oder Nachtgedanken vom Leben, Tod und Unsterblichkeit. Erste Nacht. 28 pp. Reprint of the I 755 translation, which appeared in 1762 also, q.v.; (2) Klagen oder Nachtgedanken von Zeit, Tod und Freundschaft. Zweyte Nacht. 48 pp.;

(3) Der Triumph der Christen über die Furcht des Todes. $48 \mathrm{pp}$. Reprint of the 1756 translation, which appeared also in $1762, q . v$.

Review: Das Neueste aus der anmuthigen Gelehrsamkeit. Leipzig, I 760 , pp. 7I-77. Gottsched again lavishes praise upon the meter, and seems to have forgotten, or to have missed, the previous verse translations. He again speaks of the rime of the original of Young. At the end of the review, speaking of No. 3 above, he remembers that he reviewed it in 1757 .

Sammlung vermischter Schriften zur Beförderung der schönen Wissenschaften und der freyen Künste. Berlin, I759. Vol. I, i, pp. 206-2 I9: Herm Eduard Youngs Abhandlung über die lyrische Dichtkunst. (Aus dem Engländischen übersetzt.) 
Norịce: Bibliothek der schönen Wissenschaften und der freyen Künste. Leipzig, 1760. Vol. VI, i, p. 128.

Briefe an Freunde und Freundinnen über verschiedene kritische, freundschaftliche, und andere vermischte Materien. Altona, I759.

This is a work of J. J. Dusch, in which he objects to the unbounded praise that is being heaped upon Ebert as the only perfect translator of the age, supported by arguments and citations from the Night Thoughts. Vierter Brief, pp. 37-46; 39. Brief, pp. 220-227.

I760. Dr. Eduard Young's Klagen, oder Nachtgedanken über Leben, Tod, und Unsterblichkeit. In neun Nächten. Sunt lacrymae rerum, et mentem mortalia tangunt. virg. Nebst Desselben sieben Characteristischen Satiren auf die Ruhmbegierde, die allgemeine Leidenschaft. Aus dem Englischen ins Deutsche übersetzt, durchgehends mit kritischen und erläuternden Anmerkungen begleitet, und nun mit dem nach der letzten englischen Ausgabe abgedruckten Originale Herausgegeben, von J. A. Ebert, Prof. Erster Band. Braunschweig, bey sel. Ludolph Schröders Erben, 1760 .

This is a new translation by Ebert, completely revised and recast, with the original English of Young on the pages opposite. It is replete with notes of interpretation and collateral citations from the works of other authors. This volume contains Nights I-IV, $446 \mathrm{pp}$. A second, revised edition appeared in $\times 768, q . v$. The other volumes appeared as follows: Vols. II, III, in 1763 ; Vol. IV, in 1769 , and Vol. V, in $177 \mathrm{r}, q . v$.

Reviews: Neuer Zeitungen von Gelehrten Sachen. Leipzig, I760, pp. 742-743. Special praise for the notes.

Göttingische Anzeigen von Gelehrten Sachen. Göttingen, 1760, pp. 1252-1254. . Praise for Young, Ebert's zeal, erudition, and notes.

Notice: Gelehrte Beyträge zu den Braunschweigischen Anzeigen. Braunschweig, I76r. Vol. I, p. I 19 . On p. 564, under the courses given at the Carolineum, Ebert announces that he will read Nights I-IV with advanced students. Vol. II, p. 156, announces a course in Nights V-VI; p. 554, a course in Nights VI-VII; Vol. III, p. 220, a course in Nights IV-VI: $1762-1763$.

D. Edouard Youngs Klagen, oder Nachtgedanken über Leben, Tod und Unsterblichkeit. Englisch und 
Deutsch. Der erste Band. Hannover, bey Johann Wilhelm Schmidt, I760.

This volume contains Nights I-IV, 439 pp., in hexameter translation, by Ch. B. Kayser. The English is printed on the pages opposite. A revision and extension of the 1752 translation of Nights I-IV, Göttingen, q.v. As preface this also has: Einige Nachrichten von Doctor Young, aus einem Schreiben des Herrn von Tscharner an den Hofrath von Haller übersetzet. Published with and without engravings. The second volume appeared in $1761, q . v$.

Reviews: Neuer Zeitungen von Gelehrten Sachen. Leipzig, I760, pp. 270-271. Very favorable.

Gelehrte Nachrichten. Rostock und Wissmar, r760, p. 416. Cool.

Göttingische Anzeigen von Gelehrten Sachen. Göttingen, I760, pp. 1254-1258. Considers Kayser a better student of English than Ebert.

Freymüthige Briefe, etc. Hamburg und Leipzig, 1761. 37th "Brief." Very favorable.

NoticE: Hamburgische Nachrichten aus dem Reiche der Gelehrsamkeit. Hamburg, r760, p. 547.

Neuer Zeitungen von Gelehrten Sachen auf das Jahr MDCCLX, pp. 7I3-7I4.

Review of Pensées Angloises sur divers sujets de Religion, et de Morale. Amsterdam, I 760. A translation of selections of the best sentiments of the Night Thoughts, collected according to subject, by a translator who thinks the Night Thoughts the work of an anonymous poet. Unfavorable review. Cf. infra, r 76r.

Von der heiligen Poesie.

A treatise prefixed to the I760 Halle edition of the Messias, in which Klopstock pronounces the Night Thoughts the only work of sublime poetry that deserves to be without blemish. To be found in Back and Spindler's supplement to Klopstock's works. Leipzig, 1830. Vol. IV, II, 2.

Neuer Zeitungen von Gelehrten Sachen auf das Jahr MDCCLX, pp. I37-.140.

Under the date of Feb. 25, there is a very favorable résumé and review of the Conjectures on Original Composition, announcing that a German translation is soon to appear. (Teubern's, cf. infra.)

Gedanken über die Original-Werke. In einem Schreiben des D. Youngs an den ${ }^{1}$ Verfasser des Grandison. Aus

1 The title-page has "dem." 
dem Englischen. Leipzig, bey Johann Samuel Heinsii Erben, I760.

Signed "v. T." The translator is Hans Erich von Teubern, who used the second edition. A reprint was published in r76r, q.v. Cf. also supra, pp. I4 ff.

Reviews: Das Neueste aus der anmuthigen Gelehrsamkeit. Leipzig, r760, pp. 671-680. Gottsched accuses Young of meddling with a subject of which he knows nothing. Cf. supra, p. I6.

Briefe, die neueste Litteratur betreffend. Berlin, I763. $\mathrm{X}^{\text {er }}$ Theil, I 72d-I 73d "Briefe," pp. 310-322, dated June 25, 176r. In these articles Nicolai reviews the Conjectures very favorably, with equally harsh words for the above-mentioned criticism of Gottsched. Cf. supra, p. I6.

Freymüthige Briefe über die neuesten Werke aus den Wissenschaften in und ausser Deutschland. Zweytes Stück. Hamburg und Leipzig, I760. Achtzehnter Brief, pp. r68-r69; Drittes Stück, Fortsetzung des. Achtzehnten Briefes, pp. 225-26r.

A review of the Conjectures, which objects to the style, considering the work as a "letter." This is followed by a translation of the Conjectures, according to the first edition. Signed "G.*"

Bibliothek der schönen Wissenschaften und der freyen. Künste. Leipzig, I760. Vol. VI, i, pp. r80-183.

Notice and review of the Conjectures, in words of most ardent praise. A two-page résumé. Notice of the two German translations. given above, with the remark that the work is already too well known in Germany to need any further comment.

Die Deutsche Schaubühne zu Wien, nach alten und neuen Mustern. Neunter Theil. Wien, r76r.

This collection contains Huber's translation of the Revenge: Vorrede, Zanga oder die Rache, p. iii; Story of the action without critical comment, pp. iv-vi. Zanga oder die Rache. Ein neues. Trauerspiel in Prosa, aus dem Englischen Des HERRN D. Eduard Youngs entlehnet. Von Jos. Carl Huber, Wienn, in Kraussischen Buchladen, etc., r760. 92 pp. A free translation and adaptation of Young. Cf. supra, p. I26.

Handlexicon oder Kurzgefasstes Wörterbuch der schönen Wissenschaften und freyen Künste. Zum Gebrauch 
der Liebhaber derselben, herausgegeben von Johann Christoph Gottscheden, etc. Leipzig, 1760.

The sketch of Young, p. r67r, mentions seven of his minor works with a citation from the Last Day. It mentions the tragedy Busiris, but not the Night Thoughts, or Satires, or other most important works.

I76r. D. Edouard Youngs Klagen, oder Nachtgedanken über Leben, Tod und Unsterblichkeit. Englisch und Deutsch. Der zweyte Band. Hannover, i76r.

This volume contains Nights VII-IX, $495 \mathrm{pp.}$ The first volume was published in $\mathrm{r} 760$, q.v. This is Kayser's hexameter translation continued. Cf. also $\mathbf{7} 75^{2}$.

Review: Göttingische Anzeigen von Gelehrten Sachen. Göttingen, I761, p. Ir2. Very favorable.

Moralische Gedanken über verschiedene Gegenstände der Religion, aus dem Englischen des Hrn. Young. Breslau und Leipzig, bey Daniel Pietsch, r76r.

This work was not found. The reviews below, however, show the nature of the translation.

Reviews: Hamburgische Nachrichten aus dem Reiche der Gelehrsamkeit. Hamburg, r76r, p. 725. This cites the 16 topics, under which the sentiments of the Night Thoughts are grouped.

Gelehrte Nachrichten auf das Jahr I 762. Rostock und Wissmar. I7th "Stück," pp. 182-184. The reviewer calls these selections the "kernel of the Night Thoughts."

Auserlesene Poesien Aus den meisten und besten Englischen Dichtern. Hierbevor der Frau Rowe AndachtsUebung beygefügt. Nun aber besonders gedruckt, verbessert und vermehrt. Zürich, I76r.

This contains Ir selections from the Last Day; 17 from the Night Thoughts, in all 306 verses, translated into trochaic octameters with rime in couplets, pp. 22-49.

Review: Neuer Zeitungen von Gelehrten Sachen. Leipzig, r 76r, pp. 4II-4I2. Unfavorable.

Göttingische Anzeigen von Gelehrten Sachen. Göttingen, I76r.

Review, p. 232, of Pensées Angloises sur divers sujets de Religion, et de Morale. Amsterdam, r760. A favorable estimate of this collection of sentiments from the Night Thoughts. Cf. supra, I760. 
Gedanken über die Original-Werke. Etc. Zweyte Auflage. Leipzig, I76r.

Reprint of Teubern's translation of $\mathrm{I} 760$, q.v.

Review: Göttingische Anzeigen von Gelehrten Sachen. Göttingen, 1762, p. 375. Favorable for both the original and the translation.

Briefe, die neueste Litteratur betreffend. Berlin, I763. $\mathrm{XI}^{\text {ter }}$ Theil.

The $182 \mathrm{~d}-\mathrm{r} 85_{\text {th }}$ "Briefe," pp. 59-III, r76r, contain a bitter tirade against the excessive imitation prevalent at that time, especially against the hosts of ridiculous "Night Thoughts makers." A number of these are here reviewed very sarcastically by Nicolai. Cf. supra, p. 102.

Bremisches Magazin zur Ausbreitung der Wissenschaften Künste und Tugend von einigen Liebhabern derselben mehrentheils aus den Englischen Monatsschriften gesammelt und herausgegeben. Vierter Band nebst Register. Bremen und Leipzig, r76r. XXXII, pp. 442-449: Auszug aus Conjectures on Original Composition. Lond. I 759. ${ }^{1}$ Gedanken über OriginalWerke. (Gentl. Magaz. I759. May, S. 230.)

This is a translation of the complete article in Vol. XXIX of the Gentleman's Magazine: 2r. Conjectures on original composition, pp. 230-232.

1762. Uebersetzungen einiger Poetischen und Prosaischen Werke der besten Englischen Schriftsteller, etc.

A reprint of Vol. I, Part II, Nights V-VII, $33^{2}$ pp. Cf. I756, supra. Also a reprint of Vol. II, Part I: Der Jüngste Tag; Die Macht der Religion; Paraphrase über einen Theil des Buches Hiob, 144 pp. Cf. I754, supra.

Drey Auserlesene Gedichte. Eine freye poetische Uebersetzung aus dem Englischen des Herrn Young. Frankfurt und Leipzig, I762.

A reprint of the 1759 edition, q.v. No. 2, Night II, bears the date 1759 , in this 1762 edition.

${ }^{1}$ The title has "I 749 " by mistake. 
Bibliothek der schönen Wissenschaften und der freyen Künste. Leipzig, I762.

Vol. VIII has Young's portrait as frontispiece. Notice, on p. 352, of Young's Works in 4 volumes, revised by himself. London, 1762 .

I763. Uebersetzungen einiger Poetischen und Prosaischen Werke der besten Englischen Schriftsteller. Etc.

Vierte und verbesserte Auflage. Braunschweig und Hildesheim, I763.

The fourth, revised edition of Night Thoughts I-IX, by Ebert, $507 \mathrm{pp}$. The text follows the new, annotated edition of $\mathrm{I} 760$, as far as it had appeared. q.v. The first edition appeared in $175 \mathrm{I}^{-1} 75^{2}$, the second in 1753 , and the third in $1756, q . v$.

Dr. Eduard Young's Klagen, oder Nachtgedanken über Leben, Tod, und Unsterblichkeit ... J. A. Ebert, Prof. Zweyter Band. Braunschweig, I763.

For full title, cf. supra, I760. This volume contains Nights V-VI, $377 \mathrm{pp}$. The third volume also appeared this year, with Nights VIIVIII, $547 \mathrm{pp}$. The first volume was published in 1760 , the fourth in I 769, and the fifth in I77I, q.v. The second, revised edition of Vols. I-III, appeared in $1768, \mathrm{I}_{769}, \mathrm{I} 774$, respectively, q.v. The numerous reprints are given under their respective dates.

REviews: Bibliothek der schönen Wissenschaften und der freyen Künste, Leipzig, I763. Vol. IX, ii, pp. 270-272. Favorable, but with doubtful commendation of the lengthy notes. Review of Vol. II.

Allgemeine deutsche Bibliothek. Berlin und Stettin, I766. Vol. III, i, pp. 197-203. Review of Vol. III. Favorable, with both praise and blame for the copious notes.

Resignation in Two Parts and a Postscript. To Mrs. $\mathrm{B} * * * * *$ Die Verläugnung in Zwey Theilen nebst einer Nachschrift, an Mad. B***** von D. Eduard Young. ... Altona, I 763 .

A prose translation, with the English original on the pages opposite. The work of J. J. Dusch. I75 pp.

Reviews: Hamburgische Nachrichten. Hamburg, i 763, pp. 2IO-2II.

Altonaischer Gelehrter Mercurius. Altona, I763, p. I04. Ardent praise.

Ausführliche und kritische Nachrichten von den besten und merkwürdigsten Schriften, etc. Lindau und Leipzig, 1764, p. 332. Harsh criticism. 
Die Gelassenheit im Leiden. An die Frau B******* ... Ein Gedicht, von Dr. Eduard Young. Aus dem Englischen übersetzt von J. A. Ebert, Prof. Braunschweig, im Verlag der Fürstl. Waysenhausbuchhandlung, $\mathrm{I}_{7} 6_{3}$.

A prose translation, $86 \mathrm{pp}$. The second edition appeared in $\mathrm{I} 766$, the third in $1776, q . v$.

Reviews: Gelehrte Beyträge zu den Braunschweigischen Anzeigen. Braunschweig, 1763, pp. 305-328. Favorable. Numerous passages are quoted.

Altonaischer Gelehrter Mercurius. Altona, 1763, p. 253.

Ausführliche und kritische Nachrichten von den besten und merkwürdigsten Schriften, etc. Lindau und Leipzig, I764, pp. 324-332. Favorable. Numerous passages are also quoted here.

Sammlung vermischter Schriften zur Beförderung der schönen Wissenschaften und der freyen Künste. Berlin, 1763. Vol. VI, Stück I.

The preface to the translation: Versuch über Popens Genie und Schriften, pp. $1-7$, contains Warton's tribute to Young's character and works.

Brittische Bibliothek. Sechster Band. Leipzig, ${ }^{1763}$.

In a list of books sold by C. Fritsch, in Leipzig, six editions of works of Young are enumerated.

1764. Trauerspiele aus dem Englischen übersetzt durch Johann Heinrich Schlegel, Professor bey der Universität zu Kopenhagen und Secretär in der Königlich-Dänischen Kanzley. Kopenhagen und Leipzig, verlegts Friedrich Christian Pelt, I764. Pp. 21 I-332: Die Brüder, ein Trauerspiel, des Herrn Eduard Young; pp. 333336: Historische Nachrichten.

A good translation in the meter of the original, i.e. blank verse. The historical sketch points out the use that Young made of Roman history as found in Livy. The pertinent passages of Livy are cited.

Reviews: Neuer Zeitungen von Gelehrten Sachen. Leipzig, I764, pp. 433-434. Favorable.

Bibliothek der schönen Wissenschaften und der freyen Künste. Vol. XII, i, pp. 76-79. Favorable. 
Briefe, die neueste Litteratur betreffend. XVIII ${ }^{\text {ter }}$ Theil. Berlin, I764.

The $283 \mathrm{~d}-284$ th "Briefe," pp. rr9-180, discuss the use of hexameter verse in German poetry, comparing Kayser's hexameter translation of the Night Thoughts with Ebert's prose translation as representative of Young, to show the reasons why the Night Thoughts should not be translated into hexameters, and why the German language is not adapted to that form of verse. The articles are by Resewitz, and cite many passages from both translations, also some verses from an unpublished hexameter translation by his friend "D." (Mendelssohn?)

I765. Dr. Eduard Young's Klagen, oder Nachtgedanken über Leben, Tod, und Unsterblichkeit. . . . J. A. Ebert, Prof. .. . Schaffhausen, verlegts Benedict Hurter, Provisor, 1765 .

Vol. I, Nights I-IV, 350 pp.; Vol. II, Nights V-VI, 260 pp. A reprint of the 1760 edition, German text only, with abridged notes. Vol. I was reprinted in Schaffhausen, in ${ }_{7776}$; Vol. II, in $1777, q . v$.

Der Freymüthige, oder Der Englische Greis, von Young. Hamburg, I 765-1 767 .

An adaptation of the Night Thoughts, in six parts, "Ist-23d Stück," $402 \mathrm{pp}$.

Briefe zur Bildung des Geschmacks An einen jungen Herrn von Stande. Zweyter Theil. Leipzig und Breslau, I765. XVIII Brief, pp. 337-364: Young's Nachtgedanken.

This is a work of J. J. Dusch and contains ardent admiration of the Night Thoughts. He chooses Nights VI-VII as best suited to his discussion. Innumerable passages are cited as translated by Ebert and Kayser.

Reviews: Königsbergische Gelehrte und Politische Zeitungen auf das Jahr r766. Calls them harmless contributions.

Allgemeine deutsche Bibliothek, I768. Vol. VII, ii, pp. I42-r59. Objects to Dusch's characterization of the Night Thoughts, which says that the poem goes directly to the point in its arguments, without digression, episode, or exotic elaboration. Both of these reviews are by Herder. Cf. Sämmtliche Werke, edited by Suphan. Vol. I, pp. II5-rr8; Vol. IV, pp. 290-29r.

Belustigungen für das Herz und den Geschmack in 
auserlesenen Schilderungen von Young, etc., etc. Frankfurt, 1765 .

REvIEw : Königsbergische Gelehrte und Politische Zeitungen, r765, by Herder. This work is a prose medley and conglomeration of mediocre poetry from Gellert, Kleist, Lange, Dusch, etc., which Herder considers unworthy of print. Cf. Herders Sämmtliche Werke, edited by Suphan. Vol. I, p. Ior.

This was not to be had.

Der Glückselige, eine moralische Wochenschrift. Halle, I765. Sechster Theil. Das 222. Stück, pp. 20I-203.

An essay: Ueber den Trieb zum Leben und zur Freyheit, p. 20r, cites in free translation numerous thoughts from the Night Thoughts on the desire to live and the reluctance to meet death.

Schreiben über die Frage : ob das Lesen der Alten an dem Mangel der Original-Scribenten Schuld sey, abgefasst von Joh. Jac. Rambach, Rektor des Quedlinburgschen Gymnasii, I 765 .

A long discussion which takes up Young's arguments in his Conjectures and attempts to refute them. Reprinted in I 77I, q.v.

REview: Königsbergische Gelehrte und Politische Zeitungen. Ioth "Stück." February, I766. Cf. Herders Sämmtliche Werke, edited by Suphan. Vol. I, pp. I2I-I23.

Göttingische Anzeigen von Gelehrten Sachen. 49. Stück. Den 25. April, I765, p. 400.

Altonaischer Gelehrter Mercurius auf das Jahr 1765. 22. Stück. Den 30. May, I765, p. I92.

Notices of the death of Young.

I766. Die Gelassenheit im Leiden. An die Frau B $* * * * * * *$ Ein Gedicht, von Dr. Eduard Young. Aus dem Englischen übersetzt von J. A. Ebert, Prof. ... Zweyte verbesserte Auflage. Braunschweig, 1766.

The first edition appeared in 1763 , the third in $1776, q . v$.

Briefe über Merkwürdigkeiten der Litteratur. Erste und

Zweyte Sammlung. Schleswig und Leipzig, I 766.

A series of reviews by Heinrich Wilhelm von Gerstenberg. A close comparison of Young's Revenge with Shakspere's Othello, pp. II4125. A discussion of the Danish poet Tullin contains frequent com- 
parisons with the Night Thoughts, pp. I7I, I72, I 73, I 75. Cf. also Dritte Sammlung, 1767 , p. 277. Reprint in Deutsche Litteraturdenkmale des 18. und ro. Jahrhunderts. A. v. Weilen. Vols. XXIX-XXX, I888-189o.

I767. Einige Werke von Dr. Eduard Young. Aus dem Englischen ins Deutsche übersetzt, und nun nach der letzten Ausgabe des sel. Verfassers verbessert von J. A. Ebert, Prof. Erster Theil. Braunschweig und Hildesheim, bey sel. Lud. ${ }^{1}$ Schröders Erben, 1767 .

This new edition is almost identical with the $\mathrm{I} 760$ annotated edition, as far as the latter had appeared, Nights I-VIII, but without notes and English original. Part I contains Nights I-IX, 383 pp. Part II contains: Der Jüngste Tag; Die Macht der Religion; Paraphrase über einen Theil des Buchs Hiob; Der wahre Werth des menschlichen Lebens; Der nicht fabelhafte Centaur; Zwey poetische Sendschreiben an Herrn Pope, 488 pp. A second, revised edition appeared in I 777, q.v. The third part appeared in $1772, q . v$.

REVIEW: Allgemeine deutsche Bibliothek, r769. Vol. IX, ii, p. 237.

D. Eduard Youngs Trauerspiele, nebst der Boadicea, einem Trauerspiele des Herrn R. Glovers. Aus dem Englischen übersetzt. Neue Auflage. Leipzig, bey Adam Heinrich Hollens Witwe, 1767 .

Contains: Busiris; Die Rache; Die Brüder, pp. I-322. German prose translation. Reprint of the 1756 edition, q.v.

Review: Theorie der Poesie . . . M. Ch. H. Schmid. Theil II, p. 46. Leipzig, 1768 .

Theorie der Poesie nach den neuesten Grundsätzen und Nachricht von den besten Dichtern nach den angenommenen Urtheilen von M. Christian Heinrich Schmid. Leipzig, I767.

Part I contains many reviews of Young's works: Conjectures, p. 4I ; Notice of his death, p. 60; Night Thoughts, p. I85; Satires, p. 239; Lyrics, p. 316; Tragedies, p. 476.

REview: Deutsche Bibliothek. Klotz. Halle. Zweyter Band. Achtes Stück. Not in sympathy with Schmid's praise of Young; very harsh criticism of the damage that Young's influence was doing in Germany.

1 The title-page has "Ludw" by mistake: the name is Ludolph. 
Allgemeine deutsche Bibliothek, I767, Vol. V, i; I, pp. 2-8.

A review of J. J. Dusch's Poetical Works points out the influence of Nights VI-VII on Dusch's fifth book on the immortality of the soul, p. 8.

Altonaischer Gelehrter Mercurius auf das Jahr I767. I3. Stück, pp. IO2-103.

A short discussion of Young's Conjectures, and an advance notice of J. G. Meusel's De Veterum Poetarum Interpretatione, a work said to be directed against Young's views. A short sketch of Young's life is given, 2rst "Stück," p. I68.

Der Weise, eine moralische Wochenschrift. Erster Theil. Halle, 1767 .

The articles: Betrachtungen am Geburtstage; Die Vermischung des Vergnügens und Missvergnügens, pp. I1 7, I19-120, 125, 160, 168, cite passages from the Night Thoughts.

Neue Bibliothek der schönen Wissenschaften und der freyen Künste. Berlin und Stettin, ${ }_{1767}$.

Vol. III, ii, pp. 330-34I, contains a sketch of Young's life and works, - a glowing tribute and eulogy; Comparison of the Revenge and Othello; Discussion of Busiris and the Brothers; Estimate of the Night Thoughts.

Review of the above-cited sketch, in: Göttingische Anzeigen von Gelehrten Sachen. Göttingen, 1767, p. 278.

I768. Dr. Eduard Young's Klagen, oder Nachtgedanken über Leben, Tod, und Unsterblichkeit. . . . J. A. Ebert, Prof. Erster Band. Zweyte verbesserte Auflage. Braunschweig, bey sel. Ludolph Schröders Erben, I768.

The second, revised edition of the annotated edition of $\mathrm{r} 760, q . v$. for full title, etc. $423 \mathrm{pp}$.

Reviews: Almanach der deutschen Musen. Leipzig, I77r, p. r40. Allgemeine deutsche Bibliothek, r77r, p. 228.

Dr. Eduard Young's Klagen, oder Nachtgedanken über Leben, Tod, und Unsterblichkeit. . . . J. A. Ebert, Prof. . . . Dritter Band. Schaffhausen, I768.

This volume contains Nights VII-VIII, 397 pp., and is a reprint of

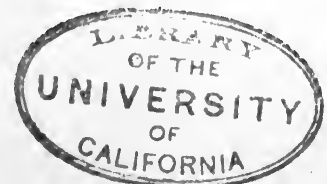


the edition of $176_{3}$, with abridged notes, German text only. It was reprinted in $\mathbf{1} 777$.

Die Brüder: ein Trauerspiel, aus dem Englischen übersetzt. Frankfurt und Leipzig, I 768 .

This was located in Vienna, but was not obtainable at the time. It is most likely a reprint of the edition of $1756, q . v$.

Deutsche Bibliothek der schönen Wissenschaften herausgegeben vom Herrn Geheimdenrath Klotz. Erster Band. Drittes Stück. Halle, I768.

A review of: Vergleichung des Zustandes und der Kräfte des Menschen, etc., translated from the English, has an unfavorable opinion of the Night Thoughts, pp. I8I-182. In Vol. II, p. 8, Klotz corroborates Gleim's opinion, that Young is not a savior of man.

I769. Dr. Eduard Young's Klagen, oder Nachtgedanken über Leben, Tod, und Unsterblichkeit. . . . J. A. Ebert, Prof. Vierter Band. Braunschweig, bey sel. Ludolph Schröders Erben, I 769 .

This volume contains Night IX, with appendixes, $33^{6} \mathrm{pp}$. Of this annotated edition, with the English original on the pages opposite, Vol. I appeared in I760; Vols. II-III, in 1763 ; Vol. V, in I77I, q.v.

Reviews: Deutsche Bibliothek. Klotz. Halle. Vol. III, pp. 636-644. Very sarcastic and caustic. Calls Young the king of poetic night owls (Uhus).

Almanach der deutschen Musen. Leipzig, I770, p. I23.

Allgemeine deutsche Bibliothek, I77r. Vol. XV, i, pp. 227-228.

Dr. Eduard Young's Klagen, oder Nachtgedanken über Leben, Tod, und Unsterblichkeit. . . . J. A. Ebert, Prof. Zweyter Band. Zweyte verbesserte Auflage. Braunschweig, I769.

This volume contains Nights V-VII, $357 \mathrm{pp}$. Annotated, with the English original on the pages opposite. The first edition appeared in ${ }^{7} 76_{3}, q . v$. for full title, etc.

Review: Allgemeine deutsche Bibliothek, I771. Vol. XV, i, p. 228.

Göttingische Anzeigen von Gelehrten Sachen. Göttingen, I769, p. 934 .

Notice of Ebert as the excellent translator of the Night Thoughts, in recommending another translation by him. 
Persius und Demetrius oder die feindlichen Brüder. Ein Trauerspiel in Versen und fünf Aufzügen aus dem Englischen des Hrn. Doctor Young übersetzt. Prag, I769.

An anonymous translation in Alexandrines. 107 pp. Monotonous.

Neuer Zeitungen von Gelehrten Sachen auf das Jahr MDCCLXIX. Leipzig.

A review of Le Tourneur's translation and adaptation of the Night Thoughts ( 1769 ), pp. 721-723. Ardent praise for this remodelling of Young. The work contains parts of six other works of Young.

Altonaischer Gelehrter Mercurius auf das Jahr 1769.

Notice of the above-cited translation by Le Tourneur, p. 408.

Neue Bibliothek der schönen Wissenschaften und der freyen Künste. Berlin und Stettin, 1769 .

Also a review of the above-mentioned translation: Les Nuites de Young. The reviewer prefers Ebert's translations. Vol. IX, i, p. 177 .

Göttingische Anzeigen von Gelehrten Sachen. Göttingen, I769.

A favorable notice of the translation of Night I, by Conte de Bissy, Paris, p. 1403 .

M. Ch. Hein. Schmids Zusäzze zur Theorie der Poesie und Nachrichten von den besten Dichtern. Dritte Sammlung. Leipzig, I769.

In a review of: A Comparative View of the State and Faculties of Man with those of the Animal World, Schmid objects to the opinion that Young's Night Thoughts must be distasteful to a person of refined taste, pp. 4-6.

I770. Der Nordische Aufseher herausgegeben von Johann Andreas Cramer. Dritter und letzter Band. Leipzig, I770. I59. Stück, pp. 328-339.

A review and résumé of the Conjectures on Original Composition. A close, running translation, without verbatim quotations.

Unterhaltungen. Hamburg, I770. Vol. X, p. 539. 
Notice and review of the publication by Swan of: The Merchant a Naval Lyric: Written in Imitation of Pindar's Spirit. On the British Trade and Navigation, by E. Young, LL.D. $4^{\circ}$. The reviewer says that, if this is really a poem by Young, it should not have been printed. It is a mediocre attempt, and Young had no talent for the lyric, he concludes.

I77 I. Dr. Eduard Young's Klagen, oder Nachtgedanken über Leben, Tod, und Unsterblichkeit. . . . J. A. Ebert. Prof. am Coll. Carol. in Braunschweig. Fünfter Band. Braunschweig, I77I.

This volume contains Ebert's first translation of the Satires, annotated, and with the original on the pages opposite, $434 \mathrm{pp}$. The first volume of this edition appeared in 1760 , Vols. II-III in 1763 , Vol. IV in $\mathrm{r} 769, q . v$. for full title, reprints, etc.

Reviews: Almanach der deutschen Musen. Leipzig, 1772, p. 148. Says Ebert has now rescued this work from the disgrace of the previous miserable translations.

Neuer Zeitungen von Gelehrten Sachen. Leipzig, I772, pp. 226228. Favorable opinion of both the translation and the commentaries.

Allgemeine deutsche Bibliothek, r774. Vol. XXI, ii, pp. 543-544. Praise for the translation, but wishes the notes condensed.

Ueber den Werth einiger Deutscher Dichter und über andere Gegenstände den Geschmack und die schöne Litteratur betreffend. Ein Briefwechsel. Erstes Stück. Frankfurt und Leipzig, I77I. (Mauvillon und Unzer.)

An essay on Gellert's taste and influence, pp. 30I-312, that attributes to the popularity of Gellert the widespread influence of the "whining Night Thoughts," upon which Ebert had, according to the opinion of the critics, thrown away so much talent and zeal.

Almanach der deutschen Musen. Leipzig, I77 I, p. I49.

A review of: Theater der Britten, Part XII, Berlin, bey Himburg, gives notice of a reprint, as No. 2, of Die Rache von Young. The reviewer censures the editor, Schmid, for reprinting such miserable translations. This edition was not to be had, but is probably a reprint of the $175^{6}, \mathrm{I}_{7} 67$, or $175^{8}$ edition, $q . v$.

Johann Jacob Rambachs . . . vermischte Abhandlungen aus der Geschichte und Litteratur. Halle, I77I: Untersuchung der Frage: ob das Lesen der Alten an dem Mangel der Originalscribenten sey? Pp. 56-1or. 
This article appeared as a "Schulprogramm" in $\mathrm{I} 765, q . v$. Reviewed by Herder.

Göttingische Anzeigen von Gelehrten Sachen. Göttingen, I77 I, p. 7 I.

Notice and review of: Verités Philosophiques tirées de Nuits de Young et mises en vers libres. Moissy. Paris. Harsh criticism.

Göttingische Anzeigen von Gelehrten Sachen. Göttingen, I77 I, pp. 742-744.

Notice and review of: Oeuvres diverses de Mr. Young. Paris. 4 vols. These volumes contain: Night Thoughts, Conjectures, Tragedies, and minor works.

Neue Bibliothek der schönen Wissenschaften und der freyen Künste. Leipzig, I77I. Vol. XII, i, p. I56.

Notice and review of: Seconde Nuit de Young, traduite en vers françois, par Mr. Collardeau. Paris, I77I. This promises the first six Nights in the same style of imitation.

1772. Einige Werke von Dr. Eduard Young. Aus dem Englischen ins Deutsche übersetzt, ... von J. A. Ebert, Prof. am Coll. Carol. in Braunschweig. Dritter Theil. Braunschweig und Hildesheim, 1772 .

This volume contains the Satires, without notes and without the original, $136 \mathrm{pp}$. The text follows the first, annotated edition of 1771. Parts I-II appeared in 1767 , revised in $1777, q . v$. for full title, etc.

Allgemeine deutsche Bibliothek. Berlin und Stettin, 1772. Vol. XVI, i, pp. 127-142.

In a review of Creuz's odes and other works, Herder discusses the melancholy poets of the day, and places Young in the first rank. Cf. Herders Sämmtliche Werke, edited by Suphan. Vol. V, pp. 290-29r.

Ueber den Werth einiger Deutscher Dichter . . . etc. Ein Briefwechsel. Zweytes Stück. Frankfurt und Leipzig, r772. (Mauvillon und Unzer.)

A continuation, pp. $1-7,1_{52-153}$, of the article begun in the "Erstes Stück," in $\mathrm{I} 77 \mathrm{I}, q . v$. The writer wonders that Young was so much admired in Germany, whereas, in England, the Night Thoughts had waned in popularity at once. 
Frankfurter Gelehrte Anzeigen vom Jahr 1772.

Contains many antipathetic discussions and notices of Young: Vol. VII, pp. 17-18, 52, 335; Vol. VIII, p. 519. On pp. I77-1 78 there is an unfavorable review of a French translation of Nights IV, XII, and XV, ${ }^{1}$ by Mr. Doigni du Ponceau, in Amsterdam, I 77I. Reprint in Deutsche Litteraturdenkmale des 18. und 19. Jahrhunderts, Vols. VII-VIII, $1882-1883$.

Allgemeine deutsche Bibliothek. Berlin und Stettin, I772. Vol. XVII, i, p. 40.

A review of: Stockhausens kritischer Entwurf einer auserlesenen Bibliothek, etc., corrects the statement that Kayser's translation is incomplete. Cf. I760, I761.

I773. Beylage zun Denkwürdigkeiten des seligen Sokrates, etc. Zweite Auflage. Halle, I773.

This contains verses $78 \mathrm{I}-787$ of the Christian Triumph, Night IV. Cf. Hamann's Schriften, edited by Roth. Vol. IV, p. II4.

Der Teutsche Merkur. Weimar, I773.

Contains, Vol. II, "Stück" 2, pp. 87-92, a profuse letter from Ebert, begging space to publish some errors that occurred in his translation of the Satires.

I774. Dr. Eduard Young's Klagen, oder Nachtgedanken über Leben, Tod, und Unsterblichkeit. . . . J. A. Ebert, Prof. Dritter Band. Zweyte verbesserte Auflage. Braunschweig, I774.

This volume contains Nights VII-VIII, 534 pp., annotated, with the original on the pages opposite. The first edition appeared in 1763 , q.v. Cf. Vol. I, I 760, for full title, etc.

Dr. Eduard Young's Klagen, oder Nachtgedanken, etc. . . . J. A. Ebert, Prof. Vierter Band. Schaffhausen, $\mathrm{I} 774$.

This volume contains Night IX, German text, with abridged notes, a reprint of the 1769 annotated edition, 244 pp., and the Satires, without notes, ro7 pp. Reprinted in Schaffhausen, in 1777 .

Neuer Gelehrter Mercurius. Altona, I774.

1 This translation, like nearly all the French renditions, follows Le Tourneur's division of the nine Nights into twenty-four. 
This published, Nov. 3, as "Stück" 44: Eine Elegie von Herrn Doct. Göthe, a poem of 60 verses by an unknown author, who made free use of Nights III and IX. Reprinted in Schnorr's Archiv. Vol. XIV, pp. 185-188. Cf. infra, 1886, 1896.

I775. Epistel an die deutschen Dichter. . . Leipzig, I775. (Johann Karl Wetzel.): Die unvermuthete Nachbarschaft. Ein Gespräch, pp. 25-48.

An imaginary conversation between Sterne and Young, characterizing these writers.

Litteratur der Poesie von Christian Heinrich Schmid. ... Erster Theil. Leipzig, I775: Ueber das Genie, p. 92.

Characterization of the Conjectures.

I776. Dr. Eduard Young's Klagen, oder Nachtgedanken über Leben, Tod, und Unsterblichkeit. . . . J. A. Ebert, Prof. Erster Band. Schaffhausen, 1776.

Reprint of the 1765 edition, q.v. Nights I-IV, $350 \mathrm{pp}$.

Die Gelassenheit im Leiden. An die Frau B******* ... Ein Gedicht, von Dr. Eduard Young. Aus dem Englischen übersetzt von J. A. Ebert, Prof. ... Dritte verbesserte Auflage. Braunschweig, 1776.

The first edition appeared in $176_{3}$, the second in $1766, q . v$.

Reviews: Allgemeines Verzeichnis neuer Bücher mit kurzen Anmerkungen. Nebst einem gelehrten Anzeiger. Auf das Jahr I776. No. I296, p. 607 .

Allgemeine deutsche Bibliothek, I777. Vol. XXXII, ii, p. 464. Favorable.

Neue Bibliothek der schönen Wissenschaften und der freyen Künste. Leipzig, I 776 .

A review, Vol. XIX, ii, p. 346, of: Observations on the Night Thoughts of Young; with occasional Remarks on the Beauties of Poetical Composition. By Courtney Melmoth. The reviewer thinks Melmoth is too severe in his criticism of Young at times.

I777. Dr. Eduard Young's Klagen, oder Nachtgedanken über Leben, Tod, und Unsterblichkeit. . . . J. A. Ebert, Prof. ... Schaffhausen, 1777 . 
Reprints of Vols. II-IV, which had appeared in I 765 , I 768 , and I 774, respectively, containing Nights V-IX and the Satires. This edition of the Satires was also published separately with a new title-page.

Einige Werke von Dr. Eduard Young. ... J. A. Ebert, Prof. ... Nach der letzten Edition sehr veränderten und verbesserten Auflage. Braunschweig und Hildesheim, I 777 .

Parts I-II, 364 pp., comprise the nine Nights and other works of Young. This is a revised edition of the 1767 edition, q.v. for contents, etc.

The Complaint: or, Night Thoughts on Life, Death, and Immortality. To which is added a Paraphrase on Part of the Book of Job. A new Edition. Sunt lacrymae rerum, \& mentem mortalia tangunt. VIRG. Hamburg: Printed for C. E. Bohn. M.DCC.LXXVII. (287 pp.)

REVIEw: Allgemeines Verzeichnis neuer Bücher, etc. I779. No. 252, p. I3I.

I778. Dr. Eduard Young's Klagen, oder Nachtgedanken über Leben, Tod, und Unsterblichkeit. . . . J. A. Ebert, Prof. Fünfter Band. Schaffhausen, I778.

This volume contains the Satires and is almost identical with the edition of $\mathrm{I}_{771}$, except that the English original is not printed on the pages opposite. It contains $472 \mathrm{pp}$., and was issued as the fifth volume of the Schaffhausen edition of 1765,1768 , and 1774 , reprinted in I 776-I 777, notwithstanding the fact that the fourth volume of this edition already included the Satires. Cf. under these dates.

Basedowische Chrestomathie von Youngs Lehren der natürlichen Religion und Tugend aus Seinen Nachtgedanken, bestimmt zur Bibliothek der Rechtschaffnen und zum Vorlesen in philanthropischen Schulen aller besondern Religionen. I778. In der philanthropischen Buchhandlung bey S. L. Crusius in Leipzig, und Steinacker in Dessau.

A chrestomathy of 148 pp., consisting of selections from Ebert's first translation, comprising all the passages that have an especial moral value, arranged under their respective Nights and amalgamated into a new whole. This retains about a third of the original, omitting all that owes its existence to the exigencies of Young's life and genius, 
and special English conditions, as the preface, pp. iv-v, informs the reader.

Brittisches Museum für die Deutschen. Zweyten Bandes, Erstes Stück. Leipzig, 1778.

Contains, pp. 228-229, verses 470-527, in English, of: An Epistle to the Right Hon. George Lord Lansdowne, I 712.

Dr. Eduard Young's Klagen, oder Nachtgedanken über Leben, Tod, und Unsterblichkeit. . . J J. A. Ebert, Prof. . . B Braunschweig und Hildesheim, I778.

This is a reprint of the three parts of the $1767-1772,1777-1772$ editions, q.v. It was not found, and the only evidence of its existence discovered is the:

Review: Almanach der deutschen Musen. Leipzig, r779, p. 160. It may be a misprint for $\mathbf{1 7 7 7}$.

1779. Göttingische Anzeigen von gelehrten Sachen. Göttingen, I 779, P. 296.

Gotaische gelehrte Zeitungen auf das Jahr I 779, p. 64 . Brittisches Museum für die Deutschen. r779. Vol. IV.

Notice of the sixth volume of the works of the Author of the Night Thoughts, containing short, miscellaneous verse and prose, already printed but not heretofore incorporated in his collected works. London, 1778 .

Betrachtungen über die Englischen Dichter. Berlin, I 779 .

This article on Young, pp. 55-64, abounds in unlimited praise of all his works. The writer admits that Young's Night Thoughts called into existence a host of weak, mediocre imitations, but, he claims, the Night Thoughts are themselves the sublimest of poetry. He passes over all the other works and cites numerous passages from the Satires in prose translation to illustrate Young's excellent qualities.

1780. Sammlung von Religions- und Sittenschriften. Erster Band. Dr. Eduard Youngs sämmtliche Werke. . . . Speier, im Verlage der Gesellschaft, und zu haben bei den Eichenbergischen Erben zu Frankfurt am Mayn, I 780 .

Vol. I contains Nights I-VIII, 384 pp.; Vol. II contains: Night IX, I22 pp., Der Jüngste Tag, Die Macht der Religion, Paraphrase über einen Theil des Buchs Hiob, Der wahre Werth des menschlichen 
Lebens, pp. 123-412; Vol. III contains: Der nicht fabelhafte Centaur, Zwey Poetische Sendschreiben an Herrn Pope, $362 \mathrm{pp}$. This is a reprint of: Einige Werke von Dr. Eduard Young. . . . J. A. Ebert, Prof. . . . Braunschweig und Hildesheim, 1777, Parts I-II, German text only, without notes. The first edition appeared in 1767 . Part III, containing the Satires, has been omitted, as being unsuitable for a collection of religious writings. Cf. preface to Vol. III. However, an edition was published later, a reprint of the three volumes mentioned above, with the addition of a fourth volume, Frankfurt am Main, zu haben bei den Eichenbergischen Erben, 1782 . The preface claims that satire and religion are perfectly compatible, and, further, that Young's Resignation is worthy of a place alongside the Night Thoughts; therefore this editor published the Satires and Die Gelassenheit im Leiden, 218 pp. A reprint of the first three volumes appeared, Frankfurt und Leipzig, in 1805, q.v.

Dr. Eduard Youngs sämtliche Werke. Neue verbesserte, mit dem Leben des Verfassers vermehrte Auflage. Erster Band. . . Mannheim, I780.

This translation is the first by Professor Eckert of Mannheim. The claim that it is a new, revised edition, is somewhat peculiar, since it presumes to correct Ebert's translations, not Eckert's own. The preface adds a few irrelevant, incorrect data on Young, and declares the translator's willingness to publish with the second volume a list of his corrections, if Ebert or any one else should desire. The desire was evidently not expressed; for the second volume appeared without the list. The revision consists in a mere substitution of unimportant words. Vol. I contains the first seven Nights, 365 pp. Reprinted in ${ }_{7} 784$. Vol. II contains Nights VII-IX and the Satires, 398 pp. Reprinted in 1784 . Vol. III contains: Der Jüngste Tag, Die Macht der Religion, Paraphrase über einen Theil des Buchs Hiob, Zwey Poetische Sendschreiben an Herrn Pope, Der nicht fabelhafte Centaur (the first three letters), $39 \circ \mathrm{pp}$. Likewise reprinted in 1784 . The fourth volume does not seem to have appeared until 1784 , with the reprint of the three volumes discussed above. Cf. under $I 784$, infra.

This translation is so nearly an absolute copy of Ebert's, that one edition even printed, as Vol. IV, Ebert's translation of Letters $4^{-6}$ of the Centaur, to complete the third volume above. This fourth volume also contains Ebert's translation of: Der wahre Werth des menschlichen Lebens, and Zwey Poetische Sendschreiben an Herrn Pope, altho this last work had already been included in Vol. III.

Briefe das Studium der Theologie betreffend von J. G. Herder. Zweyter Theil. Weimar, I780. 
Night II, verses $469-471,474-479,485-487$, are used in the original. This was reprinted in the second, revised edition of $\mathrm{I} 785$. To be found in Herders Sämmtliche Werke, edited by Suphan, Vol. X, pp. 248-249. Cf. also Neue Deutsche Monatsschrift, I795, infra.

Deutsches Museum. Leipzig, I780: Schreiben an Herrn Professor Eschenburg, pp. 406-407.

A short discussion by Ebert of the Epistle to the Right Hon. George Lord Lansdowne ( 17 I2).

Klopstock. Er und über ihn von C. F. Cramer. Hamburg, I780-I793. Theil IV, p. I75.

The commentary to the Messias, Canto VI, verses 454-469, characterizes correctly Young's influence upon his time.

Charaktere teutscher Dichter und Prosaisten. Von Kaiser Karl dem Grossen, bis aufs Jahr I780. Erster Band. Berlin, I78r.

A character sketch of Ebert, pp. 339-342, dwelling especially upon him as the great, gifted translator of Young.

1781. D. Christian Heinrich Schmids Professors zu Giessen Anweisung der vornehmsten Bücher in allen Theilen der Dichtkunst. Leipzig, I 78r.

This contains biographical and bibliographical notices of Young, characterizations and criticisms of his works and of translations in various languages. It contains many incorrect dates.

1782. Dr. Eduard Youngs sämmtliche Werke. Vierter Band. ... Frankfurt am Main, zu haben bei den Eichenbergischen Erben, I782.

This is a supplementary volume to the three-volume edition of 1780 , printed in Speier. It contains, in Ebert's translation, the Satires and Resignation, 218 pp. Cf. supra, I780.

1783. Choice of the best poetical pieces of the most eminent English Poets. Published by Joseph Retzer. Vol. I. Vienna. Printed for Sonnleithner and Hoerling. MDCCLXXXIII : A Sea-Piece: containing: I. The British Sailor's Exultation. II. His Prayer before Engagement, pp. 197-207. Edward Young. 
I784. Des Dr. Edouard Youngs Werke. Verbesserte und erste vollständige deutsche Auflage. Erster Band. ... Mannheim, I784. Im Verlage der Herausgeber der Werke ausländischer schöner Geister.

This is Eckert's translation. Vols. I-III appeared in r780, q.v. Vol. III was also reprinted in 1792 . Vol. IV, bearing upon its titlepage "Erste deutsche Auflage," as does Vol. V, shows that the first edition appeared only as far as Vol. III. Vol. IV contains: The Centaur (conclusion), Der wahre Werth des menschlichen Lebens, Zwei Gedichte zum Ruhme Dr. Eduard Youngs, 359 pp. Vol. V contains: Busiris, Die Rache, Ein Seestück, $270+16$ pp. Cf. the discussion of the 1780 edition, supra. The translations of the tragedies are superior to those published anonymously earlier. The Night Thoughts of this edition were published in $1802, q . v$.

I785. Bibliothek der schönen Wissenschaften und der freyen Künste. Vol. XXX, ii, p. 295 .

The conclusion of the translation of Warton's Essay on the Genius and Writings of Pope contains a characterization of Young as a satirist.

Briefe das Studium der Theologie betreffend von J. G. Herder. Zweyter Theil. Weimar, 1785.

The second edition. Contains Night II, verses 469-47r, 474-479, $485-487$, in the original. Cf. first edition, 1780 ; also Neue Deutsche Monatsschrift, I 795, infra.

I787. Moralische Betrachtungen über den Werth des Lebens. Aus dem Französischen übersezt. Frankfurt und Leipzig, bey Tobias Göbhardt, 1787 .

The anonymous compiler says, in his preface, that he has selected passages from Le Tourneur's translation and has grouped them under new heads. Young had always seemed too sublime to him, he adds, and this is an attempt to simplify him. Chapters I-XVI are from the Night Thoughts. Chapter XVII is from the Last Day. I76 pp.

Ueber den Geist der Originalwerke. Aus dem Englischen von Young. Mit einem Sendschreiben des Herausgebers. Leipzig in der Beygangischen Buchhandlung, 1787 .

A new rendering by a person who signed himself "C.," and who was 
ignorant of the translations of 1760 and 1761 . Cf. supra, p. 18 . Also printed, "bey Johann Gottlob Hamann."

REview: Anhang zu den 53. bis 86. Bande der Allgemeinen deutschen Bibliothek, 179r. Dritte Abtheilung, pp. 1814-1815. Harsh criticism.

I789. Young's Nachtgedanken über Leben, Tod, und Unsterblichkeit, in deutschen Versen von I. C. A. Steingrüber. Göttingen, bei Vandenhoek und Ruprecht, I789.

A hexameter translation of the Night Thoughts, German text only, with notes taken from Ebert's, $540 \mathrm{pp}$. An "Anhang" has a translation of Warton's poem on the Last Day, pp. 541-542. The preface has the usual brief account of Young.

Reviews: Göttingische Anzeigen von gelehrten Sachen, 1789, pp. 737-738. Favorable.

Allgemeine deutsche Bibliothek. Vol. CI, ii, pp. 396-399. Very harsh. Says a hexameter translation is a preposterous idea. Kayser's fate should have been ample warning.

Johann Arnold Ebert's Episteln und vermischte Gedichte. Hamburg, r789.

This contains many citations from Young, where Ebert has used thoughts of his favorite English poet, viz.: lxvi, lxviii, 73, 74, 75, 76, I0I, 102, 107, 108, 109, I10, III, II2, II3, II4, II7, I18, I25, I35, 169, 297-299, 305, 326. Cf. also Vol. II, infra, r 795 .

An ode to Dr. Young, written, in 1760 , by J. Ebert, in a copy of his translation of the Night Thoughts, belonging to the Countess of Stolberg. XXXV, pp. 297-299. 26 verses.

Allgemeines Register. Neue Bibliothek der schönen Wissenschaften und der freyen Künste. Leipzig, I789: Verzeichniss der neuesten und vorzüglichsten Verlagsbücher der Dyckischen Buchhandlung, p. 288: Youngs (D. Edward) nicht fabelhafter Centaur: Aus dem Englischen.

I790. Dr. Eduard Young's Klagen oder Nachtgedanken über Leben, Tod, und Unsterblichkeit. In neun Nächten ... von Johann Arnold Ebert, Herzogol. Braunschweigischem Hofrath, Prof. am Carolinum, und Canon. Sen. am Stifte St. Cyr. Verbesserte und vermehrte Auflage. Leipzig, im Schwickertschen Verlage, I790. 
This is Ebert's final edition of Vols. I-II, annotated, English and German. Vol. I contains Nights I-IV, 408 pp., which had appeared in 1760 , second edition in 1768 . Vol. II contains Nights V-VI, 334 pp., which had appeared in 1763 , second edition in $1769, q . v$. Vols. III-IV were published in I792, Vol. V in I 794, q.v.

REVIEW: Allgemeine deutsche Bibliothek, r79r. Vol. CIII, i, p. IO9.

I79I. Dr. Eduard Young's Klagen oder Nachtgedanken nebst einigen andern Seiner Werke. Aus dem Englischen ins Deutsche übersetzt und nach der letzten von dem Verfasser selbst besorgten Ausgabe herausgegeben von Johann Arnold Ebert, Herzogol. Braunschweigischem Hofrath, Prof. am Carolinum, und Canon. Sen. am Stifte St. Cyr. Erster Theil. Verbesserte Auflage. Leipzig, im Schwickertschen Verlage, I79I.

This volume contains the nine Nights, $334 \mathrm{pp}$., German text only, without notes, the last reprint of the $\mathrm{I}_{767}$ (second, revised edition, I 777) edition. The second and third volumes appeared after Ebert's death, I 799 and I8II, respectively.

I792. Dr. Eduard Young's Klagen oder Nachtgedanken über Leben, Tod, und Unsterblichkeit. In neun Nächten ... von Johann Arnold Ebert, Herzogl. . . . Hofrath, Prof. ... Leipzig, I792.

Vols. III-IV of the final, annotated edition, English and German. Vols. I-II appeared in $x 790, q . v$. Vol. III contains Nights VII-VIII, $496 \mathrm{pp}$. Vol. IV contains Night IX, $334 \mathrm{pp}$.

I793. Handbuch der Englischen Sprache oder Auswahl lehrreicher und unterhaltender Aufsätze aus den besten englischen Prosaisten und Dichtern, nebst biographischen und literarischen Nachrichten von den Verfassern und ihren Werken. Berlin, I793.

Biographical sketch of Young, pp. 40I-402; verses I-I2 of the Resignation, in the original, p. 402 ; verses $28-188$ of Night II, in the original, pp. 402-406. Reprinted in I802, pp. 353-359.

I794. Dr. Eduard Young's Klagen oder Nachtgedanken, über Leben, Tod, und Unsterblichkeit. In neun Nächten . . . von Johann Arnold Ebert, Herzogl. . . . Hofrath, Prof. ... Leipzig, I794. 
Vol. V of the final, annotated edition, English and German, containing the Satires, $396 \mathrm{pp}$. The first edition appeared in $177 \mathrm{I}, q . v$.

A Collection out of some of the most approved English Poets, viz. . . Y Young . . . translated by the Author of the Conversation of an old Man with a Youth. Printed for Ritscher at Hannover, I794.

Sammlung aus einigen der berühmtesten englischen Dichter, nämlich ... Young . . . übersetzt von dem Verfasser des Greises an den Jüngling.

This was not found. It is by Georg Friedrich Niemeyer.

Review: Neue allgemeine deutsche Bibliothek. Vol. XIX, i, pp. 188-192.

Sammelbände deutscher Bühnenstücke XXX. No. I65: Die Rache. Ein Trauerspiel in vier Aufzügen nach Eduard Young. ... Leipzig, bey Georg August Greishammer, I 794.

This is a prose translation by Heinrich Blümner, of the Revenge, I46 pp. An adapted translation, condensing Acts III and IV into the third Act. Printed in the same form in Deutsches Theater. Vol. L. Cf. supra, pp. 126-127.

Neue Bibliothek der schönen Wissenschaften und der

- freyen Künste. Leipzig, I794, Vol. LII, i, pp. I89I92.

Review of: Les Nuits d'Young traduites de l'Anglois par le Tourneur. Paris.

Englische Blätter. Herausgegeben von Ludwig Schubart. ... Dritter Band. . . E Erlangen, I794: Ueber den Hang des Menschen zur Nachahmung, pp. 95-106, ro6-i10.

A discussion of imitation in general, followed by a criticism of the Germans for their literary imitation, drawing largely on Young's Conjectures.

Der brittische Plutarch, oder Lebensbeschreibungen der grössten Männer in Grossbritannien, etc. ... Aus dem Englischen . . . von Herrn Hofr. Meusel. Vols. VII-VIII. Also under the title: Biographieen grosser und berühmter Männer aus der neuern . brittischen 
Geschichte. Aus dem Englischen, etc. . . . von Hofr. Meusel. Züllichau, I794.

This was not found.

Reviews: Neue allgemeine deutsche Bibliothek. Vol. XVIII, ii, pp. 444-449. Neue Bibliothek der schönen Wissenschaften und der freyen Künste. Vol. XLIX, i, pp. 156-157. A review of the third edition of the English original.

Contains a review of Young's life and works.

Thanatologie oder Denkwürdigkeiten aus dem Gebiete der Gräber, ein unterhaltendes Lesebuch für Kranke und Sterbende, von M. Joachim Leonhard Nicolaus Hacker, Prediger zu Haseloff, I795. (302 pp.)

This was not found.

REview: Göttingische Anzeigen von gelehrten Sachen, I796, pp. I9I-I92. It contains selections from many writers, among them Young.

I795. Neue Deutsche Monatsschrift. Herausgegeben von Friedrich Gentz. Berlin, I795.

In an article by Herder: Ueber die Fähigkeit zu sprechen und zu hören, Vol. II, pp. 58-59, there is Night II, verses $465-487$, with Ebert's translation; pp. $63-64$ contain Night II, verses 488-497, 507-515, likewise with Ebert's translation. To be found in Herders Sämmtliche Werke, edited by Suphan. Vol. XVIII, pp. 385-386, 389-390.

Johann Arnold Ebert's Episteln und vermischte Gedichte. Zweiter Theil Nach des Verfassers Tode mit einem Grundriss seines Lebens und Charakters herausgegeben von Johann Joachim Eschenburg. Hamburg, I 795.

A sketch of Ebert's activity as translator of Young, pp. xxviii-xxxi. Correspondence of Ebert with Young, pp. 73-9r.

Neue Bibliothek der schönen Wissenschaften und der freyen Künste. Leipzig, I795. Vol. LIV, ii, pp. 212-229.

A review of: Das Seifersdorfer Thal, von W. G. Becker, Dresden, 1792, describes a melancholy copse in which a grotto of unhewn stones is dedicated to Young. A dim lamp illuminates the uncanny gloom and shows an altar, with cross and skull, the figure of a praying 
saint in mosaic, and Young's opened Night Thoughts. Another view is of a memorial to Young's children, Philander and Narcissus, in the shape of an urn with a snake twined about it.

1796. Auszug aus Youngs Nachtgedanken. Englisch und Teutsch. Halle, I796.

Selections translated by Johann Friedrich Kinderling.

Friedrich von Blankenburg Litterarische Zusätze zu Johan Georg Sulzers allgemeiner Theorie der schönen Künste, etc. Leipzig, r796-r798.

This contains many notices and reviews of Young's works and German translations of the same.

Neue Bibliothek der schönen Wissenschaften und der freyen Künste. Leipzig, 1796. Vol. LVII, ii, p. 268. I796.

A review of Fr. W. Gotter's Schauspiele attributes the fad of translating into prose to Ebert's translation of the Night Thoughts.

1798. Aussprüche der philosophirenden Vernunft und des reinen Herzens über die der Menschheit wichtigsten Gegenstände, etc., zusammengetragen aus den Schriften älterer und neuerer Denker. Jena, r798. (By "Neu-r und Wyt-h.")

This was not found, and is known only thru the:

REview: Göttingische Anzeigen von Gelehrten Sachen. Göttingen, r798, pp. ro39-1040.

I799. Dr. Eduard Young's Klagen oder Nachtgedanken nebst einigen andern Seiner Werke . . . von Johann Arnold Ebert, Herzogl. . . . Hofrath, Prof. . . . Zweyter Theil. Verbesserte Auflage. Leipzig, r799.

This volume contains: Der Jüngste Tag, Die Macht der Religion, Paraphrase über einen Theil des Buchs Hiob, Der wahre Werth des menschlichen Lebens, Der nicht fabelhafte Centaur, Zwey Poetische Sendschreiben an Herrn Pope, 412 pp. The first volume of this edition appeared in I791, q.v. for full title, etc. The third volume appeared in $18 \mathrm{rr}$.

Neue Bibliothek der schönen Wissenschaften und der freyen Künste. Leipzig, I799. Vol. LXII, i, p. I43. 
Review of: Satires d'Young, traduites de l'Anglois par T. P. Pertin. Paris, 1798. A free translation, condensing all the sentiments on men into the first chapter, those on women into the second. Everything exotic to French customs has been omitted.

I800. Dr. Eduard Young's Klagen oder Nachtgedanken über Leben, Tod und Unsterblichkeit mit Konstructionen und erläuternden Anmerkungen erleichtert von G. F. Herrmann M. A. Lehrer am Lyceum zu Wismar. Weissenfels und Leipzig, bey Friedrich Severin und Komp., I800.

An edition of the English text of the complete Night Thoughts, elucidated in copious notes, which make frequent use of Ebert's annotations, as the editor admits in his preface. $640 \mathrm{pp}$.

REviEw: Allgemeine Literatur-Zeitung des Neunzehnten Jahrhunderts. Jena und Leipzig, I800. Vol. I, No. 5, Sp. 36-38.

Allgemeiner Litterarischer Anzeiger, oder: Annalen der gesammten Litteratur für die geschwinde Bekanntmachung verschiedener Nachrichten aus dem Gebiete der Gelehrsamkeit und Kunst. Fünfter Band. Leipzig, 1800 .

A review of: A Complete Edition of the Poets of Great Britain. London, I 792-I 795. Vol. X. This contains a sketch of Young, pp. I $22 \mathrm{I}-\mathrm{I} 222$.

1802. Des Dr. Edouard Young Klagen oder Nachtgedanken. In 3 Bändchen. Aus dem Englischen. Deutschland. 1802. Zu finden in allen guten Buchhandlungen.

A reprint, without preface, of the $1780-1784$ editions of Eckert, q.v. Part I contains Nights I-V, 204 pp. Part II contains Nights VI-VII, I32 pp. Part III contains Nights VIII-IX, 2I2 pp.

Handbuch der Englischen Sprache, etc.

A reprint of the edition of $1793, q . v$. Contains a sketch of Young's life and works, pp. 353-359.

Night Thoughts by Edward Young, D.D. With the Life of the Author, and Notes Critical and Explanatory. Wienn. Printed for R. Sammer, Bookseller, I802.

1 This edition was also printed in Hamburg and other cities. Cooke's edition: Poetical Works, with the Life of the Author, was published by Hinrichs in Leipzig, without date. 
Vol. I contains Nights I-VI, I80 pp., and notes to the same, pp. 18r-209. Vol. II contains Nights VII-IX, $214 \mathrm{pp}$., with notes and index, pp. 215-262.

I803. Irene. Eine Monatschrift. Herausgegeben von G. A. von Halem. Münster. Vol. III, pp. I-6: Youngs Klage. Metrische Uebersetzung von Horstig.

This is a translation, by Karl Gottlieb Horstig, in blank verse, of the first 94 verses of Night $\mathrm{I}$.

Adrastea von J. G. v. Herder. Leipzig, I803.

Part VI, p. Io6, contains: Young. Ueber Gedanken und Rede, a translation of Night II, verses 465-47I, 474-476, 478-487. To be found in Herders Sämmtliche Werke, edited by Suphan, Vol. XXVII, pp. 392-393. Cf. also supra, I780. Herder had translated in blank verse Night I, verses I-I25, in his early Weimar days. To be found, as above, pp. $393^{-396 .}$

Part V, pp. 293-295, contains Night V, verses I-66, of Oeder's translation. Cf. supra, I 754. Werke, Vol. XXIV, 275-277.

1804. Irene. Eine Monatschrift. Herausgegeben von G. A. von Halem. Münster. Vol. II, pp. 39-50: Proben einer Auswahl aus E. Young's Satyren.

These selections from the Satires were translated and published by C. G. Hensler, Prof., Kiel. He says, in his preface, that Ebert had translated the Satires, to be sure, but into prose; whereas they need $\boldsymbol{\alpha}$ verse translation. Much of Young's satire has a too personal, national bearing, according to Hensler's view, and so he selected those passages that might concern the German reader. These passages are enumerated for Satires I and VII, to show the method pursued. Then follows his translation of 154 selected verses in blank verse, and of Satire I, verses $127^{-148}$ in the original.

Göttingische Anzeigen von gelehrten Sachen. Göttingen, I804.

Notice, p. 1520, of F. Dmochowski's Polish translation of the Last Day and Night $I$. Warsaw.

1805. Klagen oder Nachtgedanken über Leben, Tod und Unsterblichkeit in neun Nächten. Von Dr. Eduard Young. Erster Band mit dem Bildniss des Verfassers. Neue Auflage. Frankfurt und Leipzig, 1805.

This is a reprint of the three-volume Speier edition ( 1780$)$ of Ebert's 
translation of the Night Thoughts and other works of Young, q.v. for titles and contents. The two editions are identical.

1806. Der Neue Teutsche Merkur vom Jahre 1806. Herausgegeben von C. M. Wieland. Vol. III, pp. 69-79: Uebersetzungen aus Young's Satiren.

These selections are also by C. G. Hensler. The preface is like that of Halem's Irene, 1804 , q.v. supra. The passages selected from Satire II for translation are given this time, followed by his translation of I8I selected verses. He says, if the translation, as planned, is ever published, Ebert's notes will be of great value. It seems never to have appeared.

I807. Göttingische Anzeigen von gelehrten Sachen. Göttingen, 1807 .

In a review, pp. 1313-1320, of: Essays, biographical, critical, and historical, etc., by Nathan Drake, there is mention of the fact that Drake refutes the idea that is still prevalent in many parts of Germany, viz., that the Night Thoughts are a favorite national poem of the English people.

1810. Geschichte der Poesie und Beredsamkeit seit dem Ende des dreizehnten Jahrhunderts. Von Friedrich Bouterwek. Göttingen, r8ro. Vol. VIII, pp. 307-315.

A sketch of Young's life and works. The Conjectures are not mentioned.

REVIEW: Göttingische Anzeigen von gelehrten Sachen, p. ${ }_{53} 6$.

I8I I. Dr. Eduard Young's Klagen oder Nachtgedanken nebst einigen andern Seiner Werke . . . von Johann Arnold Ebert, Herzogl. . . . Hofrath, Prof. . . . Dritter und letzter Theil. Verbesserte Auflage. Leipzig, r8Ir.

This volume contains Young's Satires and Resignation in Ebert's translation, I34 Pp. The first volume of this edition appeared in I79I, q.v. for full title, etc. The second volume appeared in 1799 .

1812. Der Aufmerksame. Gratz. No. 25: Gedanken in der Winternacht aus dem Englischen des Young gesammelt und übersetzt.

This is a prose translation of selections of the Night Thoughts, that could not be found. It is the work of Julius Franz Borgias Schneller. 
1824. Abend-Zeitung auf das Jahr 1824 herausgegeben von Theodor Hell und Friedrich Kind. Dresden. Vol. IV, No. 245: Proben einer neuen Uebersetzung von Young's Nachtgedanken in der Versart des Originals. Aus der ersten Nacht, pp. 977-978.

A translation, in blank verse, by Martin Heinrich August Schmidt, of Night I, verses 67-r54. These selections were continued in 1825 , $q . v$., and incorporated in the translation of that year, q.v.

Die Poesie und Beredsamkeit der Deutschen, von Luthers Zeit bis zur Gegenwart. Dargestellt von Franz Horn. Berlin, 1824. Vol. III, pp. 82-90.

A sketch of Young and his influence.

1825. Abend-Zeitung auf das Jahr 1825. Dresden. Vol. I, No. 19: Proben einer neuen Uebersetzung von Young's Nachtgedanken in der Versart des Originals. Aus der ersten Nacht, pp. 73-74. No. 4I : (same title). Aus der zweiten Nacht, p. I6r.

A continuation of the selections translated by M. H. A. Schmidt in the Abend-Zeitung the previous year, and incorporated in the translation below, q.v. The selections published in the above-cited articles are: Night I, verses $360-370,383-434$; Night II, verses 75 -rII.

Klagen oder Nachtgedanken über Leben, Tod und Unsterblichkeit, von Dr. Eduard Young; in der Versart des Originals übersetzt von M. H. A. Schmidt. Erster Theil. Sunt lacrymae rerum, et mentem mortalia tangunt. VIRG. Dresden, I825, in der Arnoldischen Buchhandlung.

This first volume, the only one to appear, contains a brief biographical sketch of Young, and the Night Thoughts I-VI, I90 pp. An argument of each Night is given, and pp. I9I-203 contain: Anmerkungen für gebildete, doch nicht gelehrte, Leser. Selections of this translation had appeared in the Abend-Zeitung, 1824-r825, q.v. supra.

REview: Braunschweig's schöne Literatur in den Jahren I745 bis 1800 , etc. . . . von Dr. Carl G. W. Schiller. Wolfenbüttel, I845, q.v. Called "musterhaft." Schmidt is called the "scholar and successor of Ebert."

Eduard Young's Nachtgedanken. Im Versmaas der 
Urschrift übersetzt von Ch. E. Gr. v. Bentzel Sternau. Frankfurt a. M., I825. Gedruckt und verlegt bei H. L. Brönner.

This edition opens with Klopstock's Ode to Young (I752). The preface contains a brief biography of Young and calls Young the "Homer fühlender Denker." The nine Nights are published without notes or comments, 495 pp. Reprinted in Vienna in $1727, q . v$. infra.

1826. Eidora. Taschenbuch auf das Jahr 1826. Vierter Jahrgang. . . . Herausgegeben von H. Gardthausen. Leipzig und Altona: Youngs Nachtgedanken, übersetzt von A. Binzer. Erste Nacht. Ueber Leben, Tod und Unsterblichkeit, pp. 228-244.

A new, poor translation of Night I, in blank verse.

1827. Eduard Young's Nachtgedanken. Im Versmass der Urschrift übersetzt von Ch. E. Gr. v. Bentzel Sternau. Erster Theil. Wien, I827. Gedruckt und verlegt bey Chr. Fr. Schade.

A reprint of the Frankfort edition of 1825 , q.v. This edition is, however, divided into two parts, the first containing Nights I-VI, I30 pp.; the second, Nights VII-IX, I99 pp.

I832. Jahrbücher der Literatur. Wien. Vol. LVII, AnzeigeBlatt, pp. 24-36: Geist und Leben der brittischen Dichter des neunzehnten Jahrhunderts. Von Chr. Kuffner.

A short sketch of Young's characteristics, p. 25.

1835. Der Halbmensch oder das Modeleben. Ein classisches moralisches Werk, aus dem Englischen des Dr. Eduard Young, berühmten Verfassers der "Nachtgedanken," von Friedrich Wilhelm Bruckbräu, Königl. Bayer. Hauptzollamts-Verwalter zu Burghausen. Augsburg und Leipzig, in der von Jenisch und Stage'schen Verlagshandlung, I835.

A complete translation of the Centaur, $167 \mathrm{pp}$. The second edition appeared in 1840 .

1840. Der Halbmensch oder das Modeleben ... des Dr. Eduard Young, ... von Friedrich Wilhelm Bruckbräu. 
The second edition of the 1835 edition, q.v. supra.

1844. Eduard Young's Nachtgedanken. In's Deutsche übertragen von Elise von Hohenhausen, geb. v. Ochs. Verlag und Druck von H. Hotop in Cassel, I844.

A translation that omits everything that seemed to the translator to be antiquated and out of harmony with the time in which the translation was made, as is stated in the preface. Blank verse with occasional rime is used, and everything is sacrificed to the one purpose of reproducing Young line for line in the same number of verses. The suicide of her son Carl led the poetess to this task of translating the Night Thoughts. The preface contains a sketch of Young's life, etc., and some philosophical thoughts which are taken from Hegel. The translation comprises 3 I0 pp. For the second edition, cf. 1874 .

1845. Braunschweig's schöne Literatur in den Jahren 1745 bis I800, die Epoche des Morgenrothes der deutschen schönen Literatur. Zum hundertjährigen Stiftungsfeste des Collegii Carolini, von Dr. Carl G. W. Schiller. Wolfenbüttel, I845.

A sketch of Ebert as the excellent translator of Young, commendation of his services to German literature, and a survey of Young's influence in Germany, pp. 63-74.

1854. The Standard Poets of Great Brittain from Milton to W. Scott. Stuttgart. Metzler'sche Buchhandlung, I854.

This was not available. The collection is by Ludwig (Louis) Gantter. Nos. 2, 6, and I4 contain works of Young.

1868. Eine Abhandlung über den Dichter Young, von Dr. Michaelis. Programm der städtischen Realschule $\mathrm{zu}$ Königsberg in Preussen, etc., I868.

A characterization of political and literary conditions of England at the time of Young. Principal dates of Young's life, with a brief sketch of his works. Three pages are devoted to an analysis of the Night Thoughts. I4 pp.

1874. Nachtgedanken. Von Edward Young. Aus dem Englischen übertragen von Elise von Hohenhausen, geb. von Ochs. Zweite Auflage, herausgegeben und mit einem Vorworte versehen von $\mathrm{Fr}$. von Hohenhausen. Leipzig. Verlag von Robert Friese. 
This is the second edition of the 1844 Cassel edition. It appeared without date, and is given in catalogs as 1873,1874 , and 1876 . As appears from the preface, the editor thinks this is the first German translation in verse. She dwells upon the fact, further, that in England and France the Night Thoughts are given a place alongside the Family Bible, whereas in Germany, much to her chagrin, they are scarcely read. A brief sketch of Young's life. The nine Nights comprise 404 pp. Cf. supra, p. 75.

1879. Zur Textgeschichte des Klopstockschen Messias. R. Hamel. Rostock, I879.

Hamel thinks that alliteration in the Night Thoughts influenced the verse of the Messias.

REVIEW: Euphorion, Vol. I, 1894, pp. 745-747.

I886. Archiv für Litteraturgeschichte. F. Schnorr von Carolsfeld. Leipzig. Vol. XIV, pp. r85-188: Eine Elegie von Herm Doct. Göthe.

A reprint of the poem that appeared in the Neuer gelehrter Mercurius, Altona, I 774, q.v. Edited by R. M. Werner. Cf. Goethe's poem Das Alter, infra, 1896 .

I888. Deutsche Litteraturdenkmale des I8. und I9. Jahrhunderts. Vol. XXIX-XXX, I888-189o.

Reprint, edited by Alexander von Weilen, of: Briefe über Merkwürdigkeiten der Litteratur, I 766, q.v.

I890. A Critical Analysis of Edward Young's Night Thoughts, vom ordentlichen Lehrer Richard Thiel. Programm für das Schuljahr I889-I89o, etc. Berent, I89o.

Character of the literature of the first half of the eighteenth century, pp. 3-4; Analysis, pp. 4-Io; Critic, pp. II-I9. Contains inaccurate and incorrect data.

I890. Friedrich Carl Casimir Freiherr von Creuz und seine Dichtungen. Carl Hartmann. Dissertation. Leipzig, I89o. Universitäts-Buchdruckerei von J. Hörning. Heidelberg.

On Young's influence, pp. $3^{\mathrm{I}-32,} 5^{6-7 \mathrm{r}}$.

I892. Der Blankvers in Thomson's Seasons und Young's Night Thoughts. Hubert Clages. Dissertation. Halle, I892. 
Introduction, p. 3; B. Der Blankvers der Night Thoughts, pp. 2337; Silbenmessung, pp. 23-38; Wortbetonung, pp. 28-30; Versrythmus, pp. 30-37. Entirely statistical.

1894. Beiträge zur Kenntnis des Lebens und der Schriften des Dichters Fr. Carl Casimir von Creuz. Udo Bion. Dissertation. München, I894.

On Young's influence, pp. I4-2I.

Review: Euphorion, Vol. III, pp. 514-5I8.

1895. Youngs Nachtgedanken und ihr Einfluss auf die deutsche Litteratur von Johannes Barnstorff. Mit einem Vorwort von Franz Muncker. Bamberg, 1895.

Einleitung, pp. I-9; Die Englische Litteratur zur Zeit Youngs, pp. IO-12; Youngs Nachtgedanken, pp. 13-22; Der Einfluss der Nachtgedanken, pp. 23-83; Uebersetzungen und Besprechungen, pp. $84-87$.

Review: Euphorion, 1896. Vol. V, pp. I37-144, Spiridion Wukadinowic, Graz.

Vincenz Bernhard Tscharner ( $1728-1778$ ) von Gustav Tobler. Bern, r895.

A sketch of Young's influence upon Tscharner, and the latter's interest in the Night Thoughts, pp. 3, 26-27, 28, $3 \mathrm{I}$.

1896. Zeitschrift des Vereins für Volkskunde. Karl Weinhold. Berlin, I896. Vol. VI, p. 2 I r.

A comparison of a popular couplet: Der Tod, der ist ein grober Mann, as influenced by the Night Thoughts, with Goethe's poem, Das Alter. Cf. supra, I774 and I886, also pp. Iro-III.

r9or. Edward Youngs Natursinn. Richard Lange. Leipzig Dissertation, rgor. (Printed in Nordhausen.)

I. Einleitung, pp. 5-7. II. Die subjective Naturbetrachtung, pp. 7-I8. III. Die mystische Naturbetrachtung, pp. I8-24. IV. Die religiöse Naturbetrachtung, pp. 24-34. V. Die objektive Naturbetrachtung, pp. 34-59. VI. Die Wissenschaftliche Naturbetrachtung, pp. 59-68. VII. Schluss, pp. 68-72.

Edward Young's Gedicht "The Night Thoughts," ein Beitrag zur Litteratur des 18 . Jahrhunderts. Leipzig Dissertation. Bruno Heeg. (Printed in Ehrenfriedersdorf, I901.) 
Einleitung, pp. 5-7; Der Einfluss der zeitgenössischen Dichtung und Philosophie auf die "Night Thoughts" und Quellen derselben. A. Prosaische Schriften, pp. 8-28; B. Poetische Schriften, pp. 29-50.

I903. Jahrbuch der deutschen Shakespeare-Gesellschaft. Berlin, 1903. Vol. XXXIX, pp. I-42: Edward Young, On Original Composition. Ein Beitrag zur Geschichte der Shakespeare-Kritik im achtzehnten Jahrhundert. Von A. Brandl.

An essay on Young's Conjectures and its relations to Shakspere criticism. Young's predecessors, his sources, and the influence of the Conjectures are treated, followed by a reprint of the Conjectures according to the first edition, citing the emendations of the second edition, in the notes. 


\title{
INDEX
}

\author{
OF \\ PROPER NAMES, PERIODICALS, AND ANONYMOUS WORKS
}

\section{A}

Abend-Zeitung, 175 .

Abbt, Thomas, 96, $113 .^{1}$

Addison, 6, 7, $8,9,13,20,42,59,60$, 96, 105, 133 .

Akenside, 6r, 71, 89.

Allgemeine deutsche Bibliothek, 18 , 95, $150,1_{52}, 1_{54}, 1_{55}, 1_{56}, 1_{58}$, 159, I60, r6r, 167, I68.

Allgemeine Litteratur-Zeitung, 172.

Allgemeiner Litterarischer Anzeiger, I 72.

Allgemeines Verzeichnis neuer Bücher, I61, I62.

Almanach der deutschen Musen, 126, 155, I56, 158, r63.

Altonaischer Gelehrter Mercurius, I50, I5I, I53, I55.

Annalen der gesammten Litteratur, 172.

"Anthologie der Deutschen," I02, I03.

Aquinas, Thomas, Iog.

Ariosto, 24.

Aristotle, 8, I3, 35, 52.

Der Aufmerksame, r74.

Der Aufseher, oder Vormund, I30, 136.

Ausführliche und kritische Nachrichten, 103, I5O, I5I.

"Aussprüche der philosophirenden Vernunft," I7I.

Auszug merkwïrdiger Sachen, I4I. Auszüge und Urtheile, roz.

\section{B}

Bacon, 4, 5, 8, 9, 94 .

Bahrdt, K. F., 94.

Bar, I40, I4r.

Basedow, 70, 162 .

Batteux, 14, 144 .

Baumgarten, A., 20, 52.

Beaumont and Fletcher, 23.

Behn, Mrs., I25.

Belustigungen des Verstandes und des Witzes (Gottsched), 80.

"Belustigungen für das Herz und den Geschmack," I52.

Bentzel Sternau, 74, I76.

Berens, J. Ch., 28.

Berge, 60 .

Berlinische Privilegirte Zeitungen, I38.

"Betrachtungen über die englischen Dichter," 122, I63.

Beytrag zur Litteratur und zum Vergnügen, 16.

Beyträge zur neuesten Geschichte der Litteratur, 123, 142.

Bibliothek der schönen Wissenschaften, 15, 16, 22, 23, 66, 123, 124, 125, I40, 142, I43, I44, I45, I47, I 50, I5I, I66.

Binzer, A., I76.

Bissy, Conte de, 157 .

Blankenburg, $F$. von, I30, $_{3} 33, \mathrm{I} 7 \mathrm{r}$.

Blümner, H., I26, I27, I69.

Bodmer, H., Ir, 12, I3, I4, 38, 57,

1 Figures in italics refer to footnotes. 
$59,60,62,65,75,76,80,90,105$, I $20, \mathrm{I} 21, \mathrm{I} 36$.

Böckh, 97 .

Borck, II, I2.

Bouterwek, F., I 74 .

"Braunschweig's schöne Literatur," I 75, I 77.

Brawe, I27-128.

Breitinger, I2.

Bremer Beiträge, $\mathrm{x}, \mathrm{xi}, 62,63,80$, $84,88,89,90$.

Bremisches Magazin, I6, I49.

Brentano, C. M., I I9.

Briefe, die neueste Litteratur betreffend, $\mathrm{x}, 12,16,19-22,28,3^{1}, 44$, $5 \mathrm{I}, 66,68,86,89,102,107$, I 30 , I43, I47, I49, I 52 .

Bricfe über Merkwürdigkeiten der Litteratur (Gerstenberg), x, 22-26, 97, I25, I 53, I 78.

Brittische Bibliothek, I24, I25, I33, I $42, \mathrm{I} 5 \mathrm{I}$.

"Der Brittische Plutarch," I69.

Brittisches Museum, 163.

Bruckbräu, F. W., 176 .

Bucholtz, F., 31 .

Bürger, 58.

Byron, II2.

\section{C}

Cæsar, 45.

"Der Christ auf dem Sterbebette," 102.

Cicero, 8, 94 .

Clodius, 9r.

Collardeau, 159 .

Corneille, I2, 25, 124, I25, I42.

Cramer, C. F., 73, 91, r65.

Cramer, J. A., I 7, 65, 66, 83-84, 107, I $43,157$.

Creuz, 65, 78-79, I 59, I 78, I 79 .

Critische Nachrichten, I37.

Crito (Bodmer), 76, 105, I37.

Cronegk, 65, 88-89.

Crugot, xi, 65, 93-94, 98.

Curtius, M. K., I03.

C. W. C. Fr. von C., Ioz.

\section{$\mathrm{D}$}

Defoe, 60.

Deutsche Bibliothek (Klotz), 69, I54, $\div 56$.
"Die Deutsche Schaubühne," I26, I 47 .

Deutsches Museum, I33, I65.

"Deutsches Theater," I69.

Diogenes, 94.

Dmochowski, F., I30, I73.

Dodsley, R., I42.

Donatus, 39.

Drake, Nathan, I 74 .

Drollinger, 13 .

Dryden, I, 6, 7, 8, 60 .

Dusch, J. J., 67, 68, 95-96, I32, I45, I5O, I $52, I_{53}, I_{55}$.

\section{$\mathrm{E}$}

Ebert, J. A., x, I5, 46, 62, 63, 64, $66,67,68,69,70,72,73,74,76$, $78,79,8 \mathrm{I}-83,83,84,85,86,87,88$, $89,90,91,92,93,95$, I01, 104, 106, I08, II 7, I2I, I22, I29, I30, I3I, I 32, I 33, I 35, I 37, I 38, I 39, I40, I 4 I, I44, I45, I5O, I5I, I 52 , I $53, I_{54}$ I55, I56, I 57, I58, I59, I60, I6I, I62, I63, I64, I65, I67, I68, I 70, I 7I, I 72, I73, I74, I 75, I77.

Eckert, Professor, 72, 74, 122, 124, I 26, I 29, I32, I64, I66, I 72 .

Eidora (Gardthausen), I 76 .

Der Einsame, ro3.

Einsame Nachtgedanken (Müller), I02.

Englische Blätter (Schubart), I8, I69. Eschenburg, J. J., I33, I 70.

Euripides, 38.

\section{F}

Ferguson, 82.

Festus, 35.

Fischbach, F. L., I04.

Fletcher. See Beaumont.

Frankfurter Gelehrte Anzeigen, 71, $103,160$.

Freye Urtheile und Nachricluten, 140.

"Der Freymüthige," I 52.

Freymüthige Briefe, I5, 146, 147 .

\section{G}

Gannter, L., I77.

Gardthausen. See Eidora. 
"Gedanken in der Winternacht," 174.

Gelehrte Beyträge zu den Braunschweigischen Anzeigen, 145, I5I.

Gelehrte Beyträge zu den Rigischen Anzeigen, 44.

Gelehrte Nachrichten, I38, 140, 142, I43, I46, 148 .

Gelehrter Mercurius, I7.

Gellert, 65, 71, 85-86, I00, I53, I58.

Geniekult, ix, x, 21, 28, 54, 56.

Gentleman's Magazine, I6, I8, 149.

Gentz, F. See Neue Deutsche Monatsschrift.

Gerstenberg, $x, 13,15,22-26,27$, $38,68,96-97$, I 25, 1 26, I 53 .

Gesellschaftliche Bemühungen der Welt die christliche Religion anzupreizen, 103.

Gessner, 95 .

Geusau, H. von, 64, 138 .

Giseke, 84.

Glatz, 105 .

Gleim, 62, 82, 86-87, 87, 88, 90, 97, $114,115,116,12 \mathrm{r}, 156$.

Glover, 59, 81, 82, I20, 136, .42, 154 .

Der Glückselige, 153.

Göckingk, 91-92, I23.

Goethe, 58, 6r, 68, 70, 99, ro9-гіr, I61, I 78, I79.

Gotaische gelehrte Zeitungen, r63.

Gotter, F. W., I 7r.

Gottsched, x, I1, I2, I4, I5, I6, I7, $59,65,75,79,80,120$, I 21 , I 24, I30, I33, I35, I36, I44, I47, 148 .

Gottsched, Louise, I3, 79, I30, I36.

"Göttingen League (Dichterbund)," xi, 89.

Göttingische Anzeigen, 16, 62, 64, 77, 130, 136, 137, 138, 145, 146, 148, 149, 153, I55, I56, 157, 159, 163, I67, I70, I7 1 , I73, I74.

Gray, 6r, 62, 7I, 89, I I8.

Grillparzer, 128, 129 .

Guardian, 59, 129, 136.

\section{$\mathrm{H}$}

Hacker, M. J. L. N., I 70.

Hagedorn, 8I, 82, 89, I 2 I, 140.

Halem, G. A. von. See Irene.

Haller, $63,64,77,78, I I 7, \mathrm{I}_{3} 8, \mathrm{r}_{4} 6$.
Hamann, $x, 13,18,21,22,23,26,27$, 28-40, 40, 47, 52, 57, 65, 68, 96, I 60.

Hamburgische Beyträge, I39.

"Hamburgische Dramaturgie," $x$, 26-28, I30.

Hamburgische Nachrichten, 146, 148, I50.

Hamburgische neue Zeitungen, 97.

"Handbuch der Englischen Sprache," I32, I68, I72.

Hardenberg, F. von, ror.

Haug, 98.

Hegel, I 77.

Heinse, 68, 70, II5.

Hell, Theodore, 175 .

Hensler, J. G., I 22, I73, I74.

Herder, $x, 13,14,17,18,19,20,21$, $22,23,27,29,3^{1}, 32,38,40,40-57$, $58,64,68,71,72,73,74,107-109$, 116, I31, 139, 152, 153, 159, 164, 165, I66, I70, I 73 .

Hering, A. G., I03.

Herrmann, G. F., 74, I72.

Hervey, 71, 102, 108.

Heydenreich, A. H., I04.

Hölderlin, IOI, I I2.

Hohenhausen, Elise von, 75, I77.

Home, 23.

Homer, 5, 7, 8, I3, 24, 35, 38, 39, 50, $52,55,56,57,72,176$.

Horace, 37, 45, 47, 48, 49, 50, 51, $86,88,94$.

Horn, F., 175 .

Horstig, K. G., I73.

Huber, J. C., I 26, I27, 147.

Der Hypochondrist (Gerstenberg), 23.

\section{I}

Irene (Halem), 74, 122, I73, 174.

\section{$\mathrm{J}$}

Jacobi, J. G., 68, 70, 73, 87, 97, II5II 7 .

Jahrbiicher der Literatur (Kuffner), I 76.

Jean Paul. See Richter.

Johnson, Dr., 94.

Jonson, 6, 7, 8, 13.

Jung-Stilling, 99-100. 


\section{K}

Kant, 37, 54-57.

Kayser, Ch. B., 63, 64, 66, 67, 77, 79, I06, I38, I46, I48, I52, I60, I67.

Kern, P. E., Iо3.

Kind, J. F., I75.

Kinderling, J. F., I 7 I.

"Klage bey dem Tode der Geliebten," I02.

Kleist, E. von, 82, 86, 153 .

Kleist, H. W. von, I 8 .

Klinger, 58.

Klopstock, x, xi, 38, 46, 50, 60, $62,65,68,70,73,78,87,89,90-91$, 92, 95, 98, 99, го0, го1, 105, 106, Іо7, III, І1 2,16, I18, I38, 146, 165, г76, I78.

Klopstock, Meta, 90.

Klotz, 68, 69, гі6, г54, г56.

Knebel, K. L., 68, 98.

Königsbergische Gelehrte und Politische Zeitungen, 42, I52, 153.

Körner, 112 .

Kretsch, H. C., I02.

Kritische Nachrichten, II6.

\section{L}

Lange, $\mathrm{I} 53$.

Lansdowne, I33, I63, I65.

La Roche, Sophie von, 99 .

Lavater, xi, 65, 94-95.

Lenz, 58, 68, 98-99, I 2 I.

Lessing, I2, I3, I4, 22, 26-28, 31, $34,62,64,65,66,106-107,127$, I 28, I 30, I 38, I 43, I 77 .

Lessing, K. G., 114 .

Le Tourneur, I57, 160, I66, 169.

Lilo, 128.

Livy, I24, I5r.

Löwen, 102.

Lowth, R., 38.

\section{M}

Magus im Norden. See Hamann.

Matthisson, 73, I I 7-I I8.

Mauvillon und Unzer, 6I, 71, 86, I $58,159$.

Meinhardt, J. N., 23.
"Mein Vergnügen in Zürich," 102.

Melmoth, Courtney, I6r.

Mendelssohn, 19, 20, 23, 89, 96, 113, 152.

Meusel, J. G., I7, I55, I69, I70.

Michael Angelo, I 33 .

Michaelis, 70, 9I, II3-II4.

Milton, 6, 8, 16, 57, 60, 66, 76, 84, $85,91,96,98,99$, 100, 105, 107, I08, 109, II8, I77.

Moissy, 97, I 59 .

"Moralische Betrachtungen," I66.

Moralische Wochenschriften, 59, 60, I05.

Moritz, K. P., I04.

Möser, Ir 3 .

Müller, P. L. S., I02.

\section{$\mathrm{N}$}

"Nachtgedanken bey einer gefährlichen Reise," 102.

Natho, F. E., IO2.

Neue allgemeine deutsche Bibliothek, I69, I 70.

Neue Bibliothek der schönen Wissenschaften, I 24, I 25, I 55, I 57, I 59 , I6I, I67, I69, I70, I7I.

Neue Critische Briefe (Bodmer), 63,76, I 20, I 36 .

Neue Deutsche Monatsschrift (Gentz), 73, I65, I66, I70.

Neue Erweiterungen der Erkenntnis, I 2, I40.

"Neue Probestücke der Englischen Schaubühne," I43.

"Neuer Büchersaal" (Gottsched), I35.

Neuer Gelehrier Mercurius, I60, I78.

Never Zeitungen von Gelehrten Sachen, 15, 62, I30, ×31, 135, I36, I $38,1_{40}, 1_{45}, 1_{46}, 1_{48}, I_{5}$ I I 57 , I 58 .

Das Neueste aus der anmuthigen Gelehrsamkeit (Gottsched), I5, I44, I47.

Der Neue Tentsche Merkur, I22, I74. Newton, 55 .

Nicolai, I2, 16, 19, 66, 68, 147, 149.

Niemeyer, G. F., I69. 
Der Nordische Aufseher (Cramer), - I7, 66, 83, 107, 143, 157.

Novalis. See Hardenberg.

\section{$\mathrm{O}$}

Oeder, G. W., 64, 108, I39, I73.

Ogilvie, 6r.

Ossian, 50, 57, 71, 73, 89, 93, 97, 106, 118.

\section{$\mathbf{P}$}

"Pensées Angloises," 146, 148.

Percy's "Reliques," 46, 57, 71.

Pertin, T. P., 172.

Pindar, 4, 8, 32, 35, I 58 .

Plato, 8, 94, II 5 .

Plutarch, 94, I69.

Ponceau, Doigni du, I60.

Pope, I, 2, 5, 6, 7, 8, 9, 13, 16, 38, $60,67,80,81,89,94,95,97$, го०, 105, 107, 108, 109, 120, I29, I3I, I35, I4I, 142, I5I, I54, I64, I66, I 7 I.

Prior, 6r, 89.

\section{$\mathbf{R}$}

Racine, 95.

Rambach, J. J., I 7, 4I, 42, 47, I53, I58.

Ramler, 127, 144 .

Ramsay, I.

Raphael, 24.

Resewitz, 20, 152 .

Richardson, 9, 10, 63, 65, 81, 90.

Richter, Jean Paul, 70, 76, 100.

"Romantic School," II 9.

Rousseau, 99, II 8 .

Rowe, Elizabeth, 6I, I30, I48.

Ruffhead, rog.

\section{S}

Sachs, Hans, 57.

Salzmann, rog.

"Sammelbände deutscher Bühnenstücke," I69.

Sammlung vermischter Schriften, 132, I44, I 5 I.

"Scherze der Lyrischen Muse," I02.
Schiller, 70, 73, 74, 98, 104, I I I-I I2.

Schilling, ro3.

Schlegel, J. A., I4, 22, 23, 83, 84, I30, I44.

Schlegel, J. E., I3.

Schlegel, J. H., 124, I25, I5I.

Schlesische Berichte von gelehrten Sachen, 93.

"Schlesische Sammlung," 102.

Schmid, M. Ch. H., I6, roz, ro3, I22, I23, I25, I26, I30, I33, I54, I 57, I 58, I6I, I65.

Schmidt, M. A. H., 75, 175 .

Schneller, J. F. B., 74, 174 .

Schönaich, 80 .

Schubart, 18, 68, 97-98, 169.

Schuldrama, 35 .

Scott, Walter, I 77 .

Seneca, II 5 .

Shaftesbury, 8, I6, 89.

Shakspere, ix, I, 4, 6, 7, 8, II-I4, I9, $21,22,23,24,25,26,32,35$, 50, 52, 56, 57, 72, 73, 96, 108, 125, $126,127,142,143,153,155,180$.

Socrates, 30, 36, 160 .

Sophocles, 24, 25, 52, 56, 57 .

Spalding, 95 .

Spectator, 8, 9, II, I3, 59, 60.

Spenser, I, 24.

"Standard Poets of Great Britain," I 77 .

Stäudlin, G. F., ro4.

Steele, 59, 129.

Steingrüber, J. C. A., 73, I67.

Sternau. See Bentzel Sternau.

Sterne, 104, II7, I6r.

Stilling. See Jung-Stilling.

"Stockhausens kritischer Entwurf," I60.

Stolberg, Countess of, 92, 167 .

Stolberg, F. L., 92-93.

Storm and Stress, 28, 57.

"Stunden der Einsamkeit," 102.

Sucro, 90.

Sulzer, 19, I7I.

Swift, 4, 5, 6, 42, 43, 60 .

\section{$\mathrm{T}$}

Tatler, 59.

Teubern, H. E. von, I5, 16, I8, 146, I47, I49. 
Der Teutsche Merkur, I60.

"Theater der Britten," I 58.

Theremin, 105.

Thomson, I, 7I, 8I, 85, 98, 105, I78.

Thucydides, 32 .

Tickell, 133 .

Tieck, II8-IIg.

Tiedge, 70 .

Triller, D. W., 80.

Tscharner, 63, 64, 77, 77-78, 138, I46, I 79 .

Tullin, 22, 97, 153 .

$\mathrm{U}$

"Universal Lexicon" (Zedler), I r. Unterhaltungen, I33, I 57 .

Unzer. See Mauvillon.

$\mathrm{Uz}, 62,65,86,87,87-88$, 105, 116 .

Veillodter, V. K., I05:

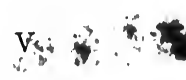

Der Vernünftler, 60.

Virgil, 6, 8.

Der Vormund. 'See Aufseher.
W

Wagner, H. L., 58, 73, II4.

Waiblinger, W., I I 2 .

Warburton, 9.

Warton, 2, 24, 6r, 85, I5I, I66, I67.

Weckerlin, II I.

Der Weise, I55.

Weisse, 2.3.

Westphälische Bemühungen, 137 .

Wettengel, F. T., I04.

Wetzel, J. K., 70, r04, I6r.

Wieland, 55, 56, 58, 6r, 65, 69, 97,

98, I05-I06, II2, I 74 .

Withof, J. L., I42.

Wordsworth, $7 \mathrm{I}$.

\section{Z}

Zachariae, 85, 87, 102 .

Zedler, I I.

Zelter, $\boldsymbol{I}$ Io.

Zimmermann, xi, 65, 94, 106.

Zum Vergnügen, I44.

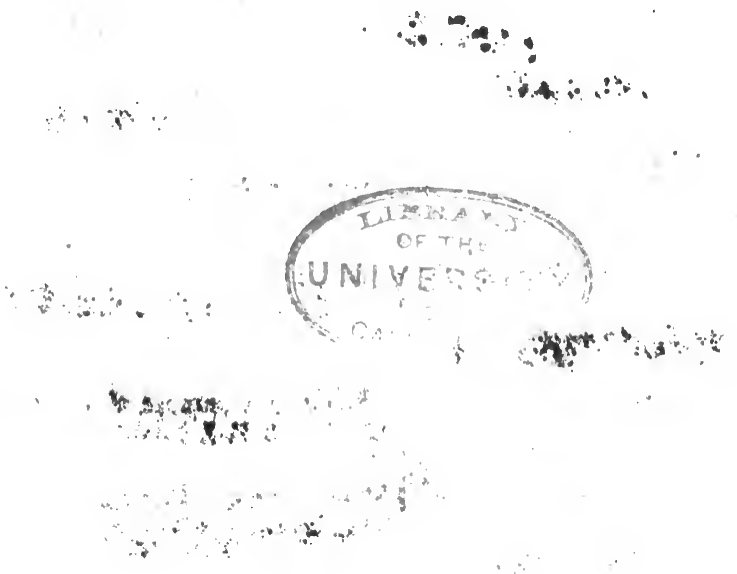




\section{RETURN CIRCULATION DEPARTMENT}

TO $\rightarrow 202$ Main Library

\begin{tabular}{l|l|l}
\hline $\begin{array}{l}\text { LOAN PERIOD 1 } \\
\text { HOME USE }\end{array}$ & 2 & 3 \\
\hline 4 & 5 & 6 \\
\hline
\end{tabular}

ALL BOOKS MAY BE RECALLED AFTER 7 DAYS

1. month loans may be renewed by calling 642.3405

6. month loans may be recharged by bringing books to Circulation Desk

Renewals and recharges may be made 4 days prior to due date

\begin{tabular}{|c|c|c|}
\hline \multicolumn{3}{|c|}{ DUE AS STAMPED BELOW } \\
\hline AU6 291983 & Apvily ec & \\
\hline REC CIR ML 30 & $832 \ln 7,05$ & \\
\hline & 4,00 & \\
\hline JAN 121986 & & \\
\hline CIRC DEC 121985 & & \\
\hline 0СТ 241987 & & \\
\hline AVIIU. Biot & & \\
\hline AUG 17198 & & \\
\hline$0 \longdiv { 2 0 1 9 9 }$ & & \\
\hline $12121 / 99$ & & \\
\hline Fel, 10,00 & & \\
\hline
\end{tabular}

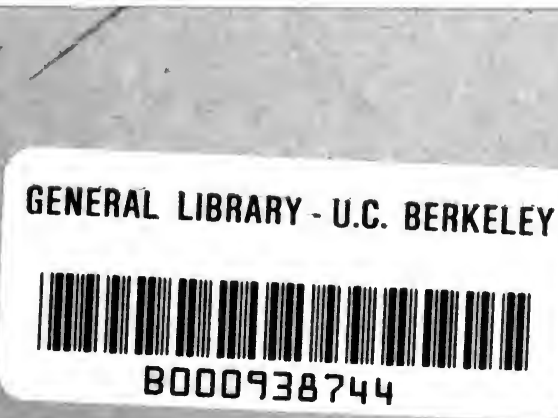


